LAND AND SOCIAI CHANGH IN EAST NEEAL

Lione L CapLan

Thesis presented for the degree of Doctor of thilosophy

University of Iondon

1966 
ProQuest Number: 10731604

All rights reserved

INFORMATION TO ALL USERS

The quality of this reproduction is dependent upon the quality of the copy submitted.

In the unlikely event that the author did not send a complete manuscript and there are missing pages, these will be noted. Also, if material had to be removed, a note will indicate the deletion.

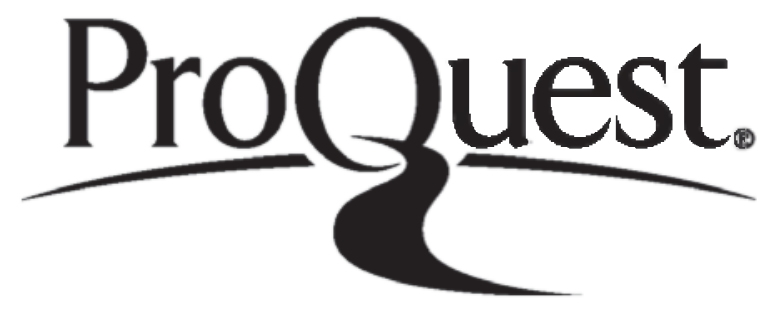

ProQuest 10731604

Published by ProQuest LLC (2017). Copyright of the Dissertation is held by the Author.

All rights reserved.

This work is protected against unauthorized copying under Title 17, United States Code Microform Edition @ ProQuest LLC.

ProQuest LLC.

789 East Eisenhower Parkway

P.O. Box 1346

Ann Arbor, Ml $48106-1346$ 
ABSTRACT

This thesis exmines some economic and political concomitarits of a systen of lond tenure - called kipat associated wath the Linbus, ono of the pooples indigenous to East Nepal. It considers some of the ways in which this system affects sucial retationships both anong the Limbus and betweon them and meinbers of other groups, especially Branins. Particusar attention is pald to the changes which have fullowed from atturations in the tenure system. The analysis is based oil data collccted ia a cluster of settienerts, inhabitod mainly by Limbus, nin the district of Ilam.

Chapter I describes the esviromental asd historical background of the area, as well as certain cultural features associatud with the principal groups inhabiting the settluments. Chapter II considers the isture of inmbu descent groups aid their relatiolis to land. The following chapter lidicates huw Guvermmeat policy affected the availability of kipet land, and lud to the energence of the household - cealt wath in Chapter IV - as the group with the greatest irterests in this lard. Two subsequent chaptexs deal with coromic ties resultig from heavy mortgaging of isipat land and the growth of comilercial sources of income outsicie the cgricuIturil economy. Chapter VII then considers the political coifiguration in the settlownts with 
particular emphasis on leadersidp and the settioment of disputes. Foctions, an their implications for limbus are also dealt with. Fialidy, Chapter VILI analyzes the structural clecvages between Limbus aid Brahmins based primarily on the cuifrontation over land, aisd views its effects on relatioiships both wathin alld outside the settiements. 
Page

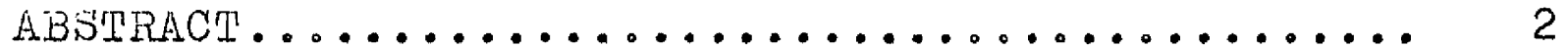

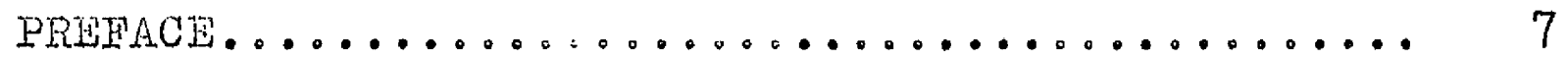

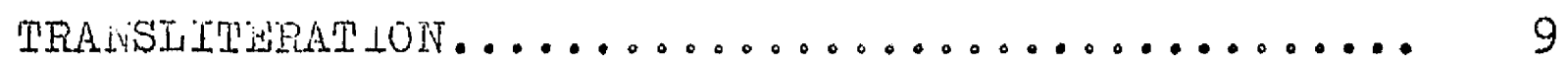

Chapter

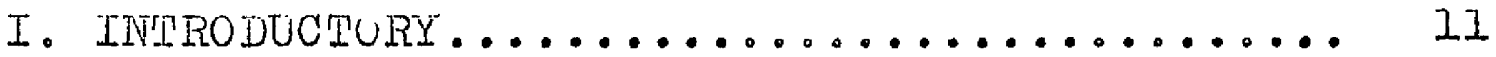

The Problen

The Background

Ilari District

The Indreni Clustex

The people

Leided renuro

II. LALD AID DESCELIT GROUPS............. 57 The Clan

The Iinease

Limbus Without kipat

Individual Kipert Rights

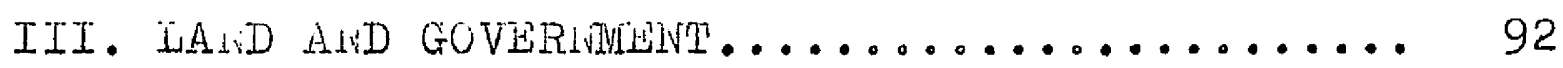

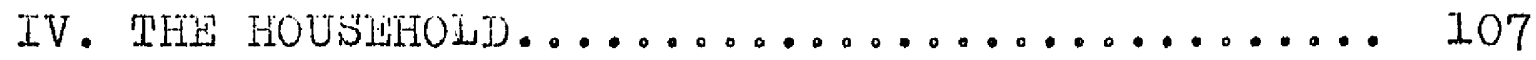

Composition

Soparation ena Inhoritance

Women's Rights in Land

Relations inthin the Household

Household as a Ritual Unit

V. THE ECONUIY: CREDLT ALID TELALCY........ 166 Mortgages

Distribution of Mortgages Loail Credit

Tenancy

The Maripuiction of Ties

VI. THL HCONOMY: JUURCES OR WEALIE........ 213 Agriculture

Recurrint Obligations

Cointrigent Lxpuiditures: Mortuary Ritos Contingent Expenditures: Marrisge

Commerciel Sources: Within the Cluster Comercial Sources: Outside the cluster Militiny service 


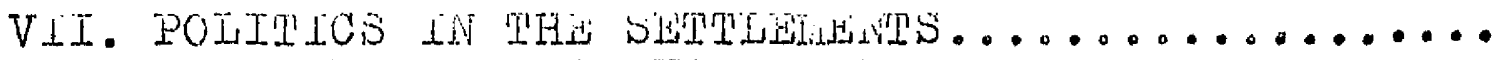
299

The Leaciership Hierarohy

Disputes over Compensation

Intra-cluster Dasputcs

Informel Hediation

Tho Panchayat

The Adrinistratıen

pactions

VILI. CULPURE AID LIPAT: THE EXTERINAL

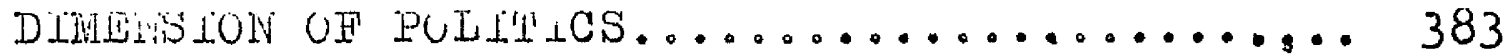

Ties Outside tho Area

Ties Within the Area

The Subba

Limbu-Bramin ReLations

Limbu Notablos: Intercalary Role

IX. CONCLUSLON......................... 440

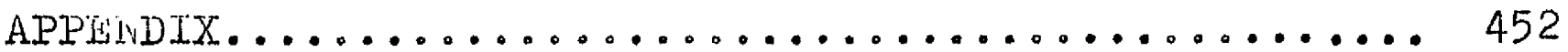

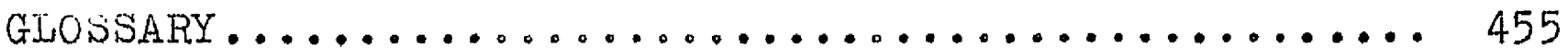

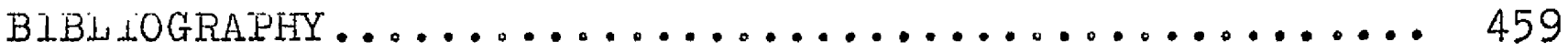

LIST OF TABLES

Chopter I:

1 Indreri Cluster: population breakdown..........

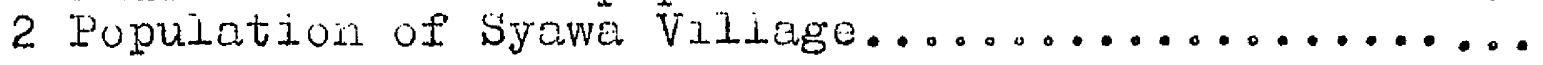

Chapter II:

3 Population of local clar segncits...............

4 Iineage Iaud ownership aud population...........

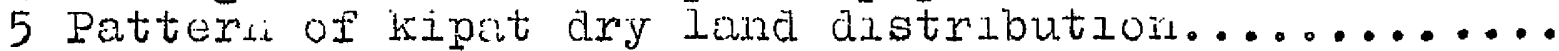

Chepter IV:

6 Attached reribers of inimbu householas............

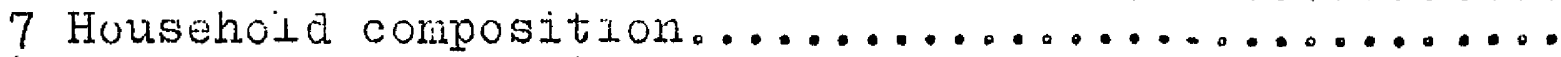

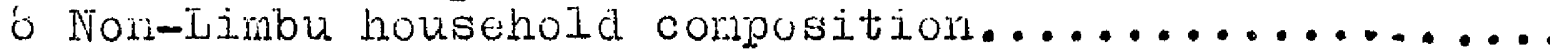

Chaptur V:

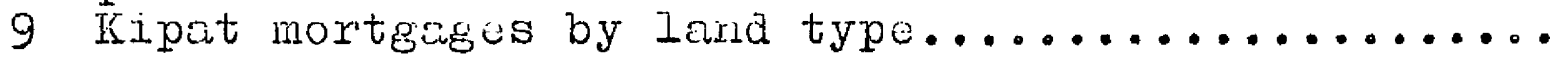

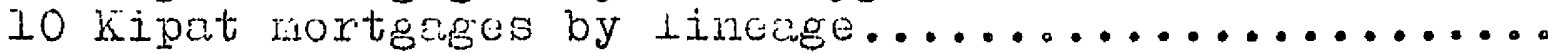

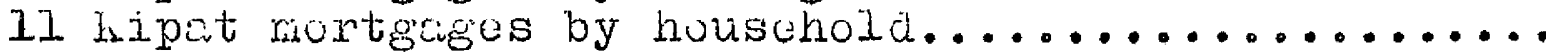

I2 Distrubutiol of mortguges anong Limbu landholders.

13 Dustributiun of nortgages thong non-linbu 


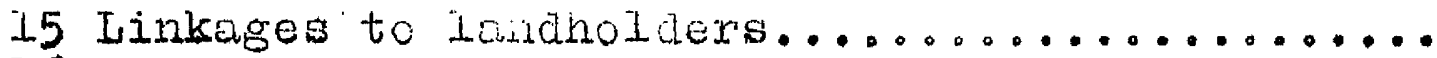

16 Comparison of nortgnge cutd Loan creait.......

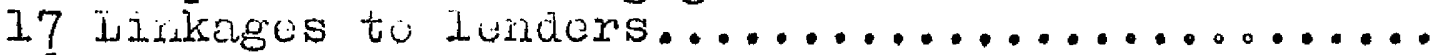

18 Comparisois of nortgage cila Loan credit

19 Distribution of cultivation rights on

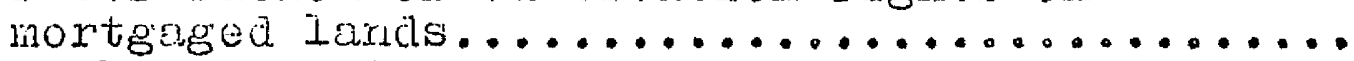

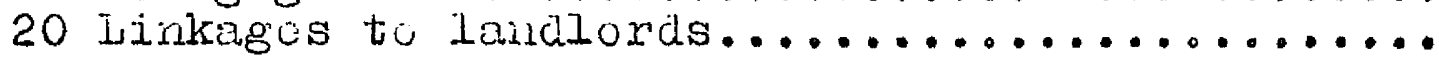

21. Compardson of distribution of nortgage, tenalicy aid Loar credit linkages............

22 Mortgage capitat uncreases due to bara........

Chapter VI:

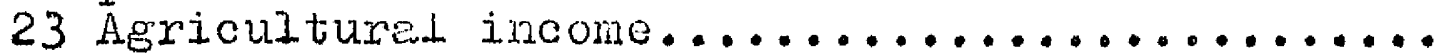

24 Production of food requirenents by

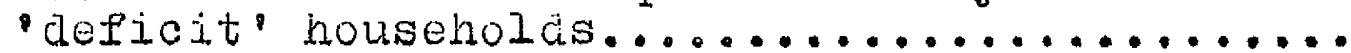

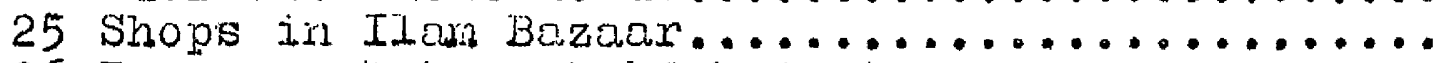

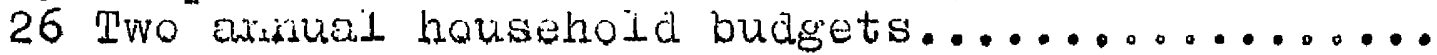

27 Distributzon of bexiduges duvolving

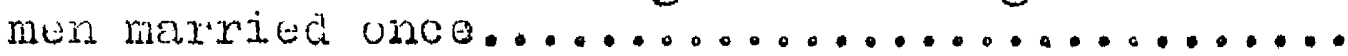

28 Distributiun of harriches involving

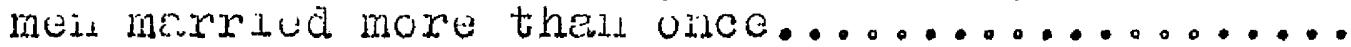

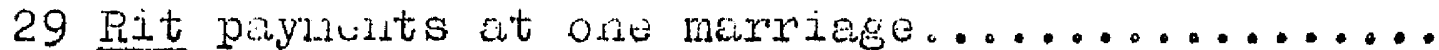

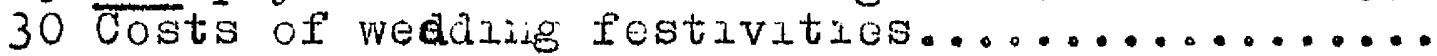

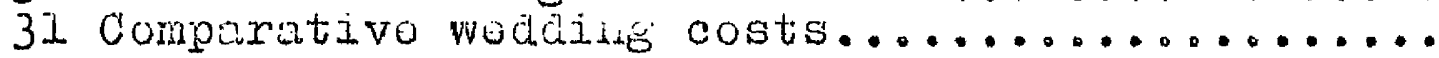

32 tarsing frum comidercid sururces...........

33 Iruome from combrcial suurces expressed as a percentage of agrculturat income.......

Chapter VIL:

34 Ownership of kipat land by subbas...........

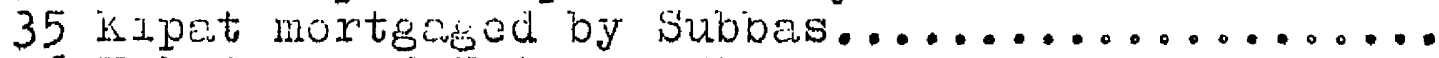

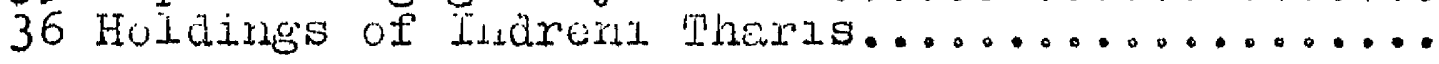

Chopter VIII:

37 Companison of nortgago distribution (in units

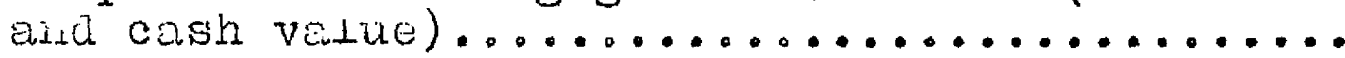

IISOS OEAPS

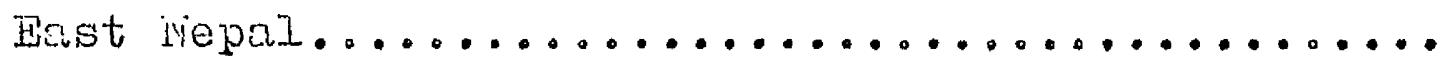
Ilan cuscliew a drinistrative divisions..........

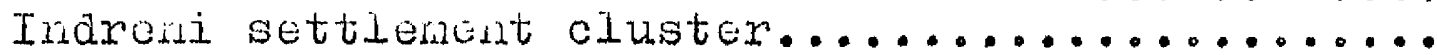
Distribution of ary Lasds iis the Inirusi Cluster. 
PREFACE

Tho date or which thistthesis is based were gathered during the course of a thirtedi-wonth field study In 1964-65. The research was made possible by a grant from the Loidon-Conneld Project for Chnose aud Suuth-east Asian Socleties. The uebec Goverumont, Caisada, provided a supplementary grant to flna+ce the preparatory stage prior to my departure for inepal. I an deeply indebted to those respousible for making these kwayds.

I must anso express my gratitude to the represontatives of His Mojesty ${ }^{p}$ Gover mont of Nepal. Hispecially helpful were the offleers of the protocol section of the Ministry for Forelgn Affairs in hathmandu wid the members of the district adininistratloil in Ilan. Ny tharks are also due to Sri Miahesh Chandra Regini for aldowing me to read his manuscript on the kipat systen before its publication, and to Sri Damoder Sharra and Sri Lakshmi Prasad Kaphle, who acted as ny assistants at various stages of the work. Whatevur proflciexcy I was able to achieve in Hepali uwes much to Mr. T. if Clark, who gave geiterously of his tume to esoblo me to begin learnirg the lasguage before I left joridor. I express my gretitude to Professor C. vol Fürer-Haimendorf who first stimulated my interest un repal ard later acted as ny academic supervisor. 
There relatis the plecsure of recording my obligation tu the people about whom this essay is written. The experituce of Livitg among then has enruched me more than I can say. 
PRAISIITERALLON

Some inepali words are treated as though they are Euglish, are glved a plurel version where necessary, and are wot undulined. Cortain proper nanes are also left in their English version. All other tems in the veriacular are rendored as close to their propur proiounciatlon as possuble wid underined in the text; they ere then traiscribed in the Glossury according to the systen devised by M.W. Clark in Introauct101 to ivepali. 
CHAPTHR I

IITRODUCTORY

\section{The Problern}

This thesis is about the social relations of land terure, and the changes in these relations which follow from nodifications in the tenure system.

Despite the great variety of tenure forms found on the Indiar sub-continent, most anthropologists who have worked in India and other parts of South Asia have neglected their study. I This is not to sugeest, of course, that the inportance of land tenure has not bees aspreciated. Generally, however, consiacration of tile problens comected with land has been subsuned in the alialysis of caste and its various attributes. Not unsturatiy, then, studies of social chonge have concentrated on the ways in which the traditionit relations betweed castes have aitered in response to a variety of externel stimuil. Thus, accounts by Basley, Rao, Guugh and Cohn have described changes taking place at the village Level as a result of the introduction of a cash voonomy and now economic and political opportunities created by Goverment. ${ }^{2}$ If we can extract a slughe tineme from these ara other recent studies it is that the patters of involution or role sumation which formerly integrated tae caste structure has begun to come

1. There are of course, exceptions. See, for exemple,
Heyer $1952 ;$ ieach, 1961b.
2. Balloy, 1957; Rao, 1957; Gough, 1955; Cohn, 1955.


asunder under the impact of industrialization.

In the context of vast liepal suciety, however, to achieve ari undorstanding of tho sociul changes which are taking place the obsurver must rugard land tenure as the key to these chances. Cindeca, harriott's observation that pas for back as we are able tu look, the social structures of littlo comunities (in the area of Indian civilization) must have beer profound af afocted by state lara poitcy" is nowhere nore appicablu than in east Nepal. I

In the Iatter half of the 18 th century imbuan, the country of the Limbus, occupying the eastomost portion of present-day Nepal, was incorporated into the Gorkha state. 2 since that tha the Govermineint has sought to extend and secure its hegumony over the limbus by means of a land policy designed to reauce - ard, presumably, eventualy to abolish - an area of land held under a customary form of terure, called "kipat". ThIs policy has wrought a nuiner of changes in the interiail structure of Limbu commaties, as well as silapd their relations with othor sections of the populatioil.

Wy fieldwork was corductud ix a cluster of four contiguous sottlenuts situctud along a ricge in the IlanDarda sub-division of ILom Uistrict in East Vepal. They are ruferrea to throughout the text as the indreni Cluster. Hilevation, terrain and a salubrious clinate allow 1. Marriott, 1955, p.187. 
for a fairly denso settlemert patterid in most parts of the district. Thure are no ructoar vidiages of the kind found in the plains, ondy a continuous flow of humesteads along the mald ridges aid the spurs which extend laterally from these ridges. Clusters of homusteads - which 1 cill settlements - are usualiy named aftor a wel-kirown peculitirity of the landscape arouid which thoy are situated, but except where distinctivo geogrephical features divide these settlements from their reighbours, the boundaries butween them are vague and, for the peoplo theriselves, yuite unimportant. Indeed, it is possible that giving lianes to settlements is a recent phenonenox. Until about fifty years agu, commications from the administration to inhabitaits in the Lindreif Cluster, fox exampe, referred to the individual's place of residence either as Mein or Ilam-Darde, but never to the settienurt inanes in use nowerdays.

Giveri the settlemut configuration how then was the unit of study to bo defired? The groat hajority of anthropulogical cocounts of social life in India have centerea on the village. True, even tho most physically isolated viliage carnot bu t. catca as a sccial isolate, so that the factors bewring on it from the outside must be taken into consiatration. I But a village study has the advantage of being able to concentrate on a clearly defin1. Op1er, 1956, pp.5-10. 
able facu-to-face community within which the external forces cais be seeti to affect the intemal structure.

In the absence of such an arena, the choice of a focal unit must be determined by the interests of the study. Bince the problens in which I was most interested concerined in crude terins, the social concomitents of kipat land terure, I chose to study a cluster of settlements inhabited mainiy by timbus. The Indreni Cluster is not a defiritive geographical unit, surrounded as it is on three sides by other settlenents into which it merges. Nor is it a unit nu ary adininistrative seiso. It has sociological significance, however, in that it is recognized by people in the surrounding area es the place where the Iinbus live, aid is referred to as 'Limbu gaon'.

There are maily such Iimbu clusters situated throughout llam. The location of their settlements in the midst of non-dinbu populations reflects both the manner in which the district came to be settled and the effucts of Govorirunt Land policy. Since this is dealt with in some detail in the following chapters, only a brief outilise ised bo given here.

During the yecrs prior to the absorption of Ilam into the Gorkha state Limbu settloments had been established throughout the district. These settlomuts wero gencrally situated on the tups of riuges, and the settlers laid chain used in a veriety of contexts. jue below, p. 39 . 
to large tracts of forest adid uncultivated bush surrounding the aruas they inhabited. Fullowing the Gorliha conquest large-scole migrations of nom-Linbus from the west entered the district and the inbus mede gullorous grants of land to accomodate the immigrant settlers. Towerds the eis of the 1.9th century the Government changed the system of tenure under which these lands had been granted, thus effectively removing theil from Limbu control. By aid large, the Limbus were left only the lands they had not granted the imigignints, which in effect weart those which they were cultivating and living on thenselves. This historical process is mirrored in the settlenut patteris, which finds the origlnal limbu settlens now Living on lands held primarily under kipat toure, and surrounded by settlements of iton-limbus who exjoy rights to land undor a different tenure system (raikar). To a linited extent, the wimbu settlenunts contain some non-linbus as well - indicating that somo of the lands in their miast are held under ranker tenure. About oue-fifth of the imhabitants of the lodreri Cluster, for oxample, are menbcrs of othwr groups sutted intersticlally mone the Imbus.

Although tho Locus of this study is the lridreni settlemut cilister, it is the Lurnou sector wathin the Clustur which provides the focus for my ancisis. I can not, of course, ignore the existence of the non-jimbus Living wathin on for that nattor in the area surrounaing 
the cluster. But the redations betweer the Limbus and their ileighbours as well as tho changus which are taking place in theso relations are presentod essuminly from the stailapoint of the Limbus. In a similar venn, I make no attenpt to disregard the presence of Guverment - of 'combuling hulghts' as dursiey puts it' - or the new opportunitzes which exist fur earring cash in and outside the area. Thuse are treatod as factors of greater or lesser import influencing the social scoile.

I an not prepared to say that the detailed changes recorded in this study of Inaruil Limbus are representative of othur settlemort clusters in Limbuan or evon the district of Ilam. 2 Factors such as the ratio of Limbu to nonLimbu population, tho avallability of land or the existence of alterutives to agriculture vary from one locality to another and influcine the oxtent ard pace of charge in any ore settlinint cluster. Nevertheless, from the documents and writings I have seen, ${ }^{3}$ and from superficlal observations unde during visits to other perts of the region it is abundantly clear that Goveriment land policy has contributed to bring about far-reaching changes in the

1. Worsley, 1961, p.219.

2. As Cohen points out, from the sociological point of view, the quustion of typiculity is of 10 real significance. $(1965, p .176$.

3. Uniess otherwise indicated, the historical naterial presented in this thesis is based on documunts or on published works which refer to primery sources. 


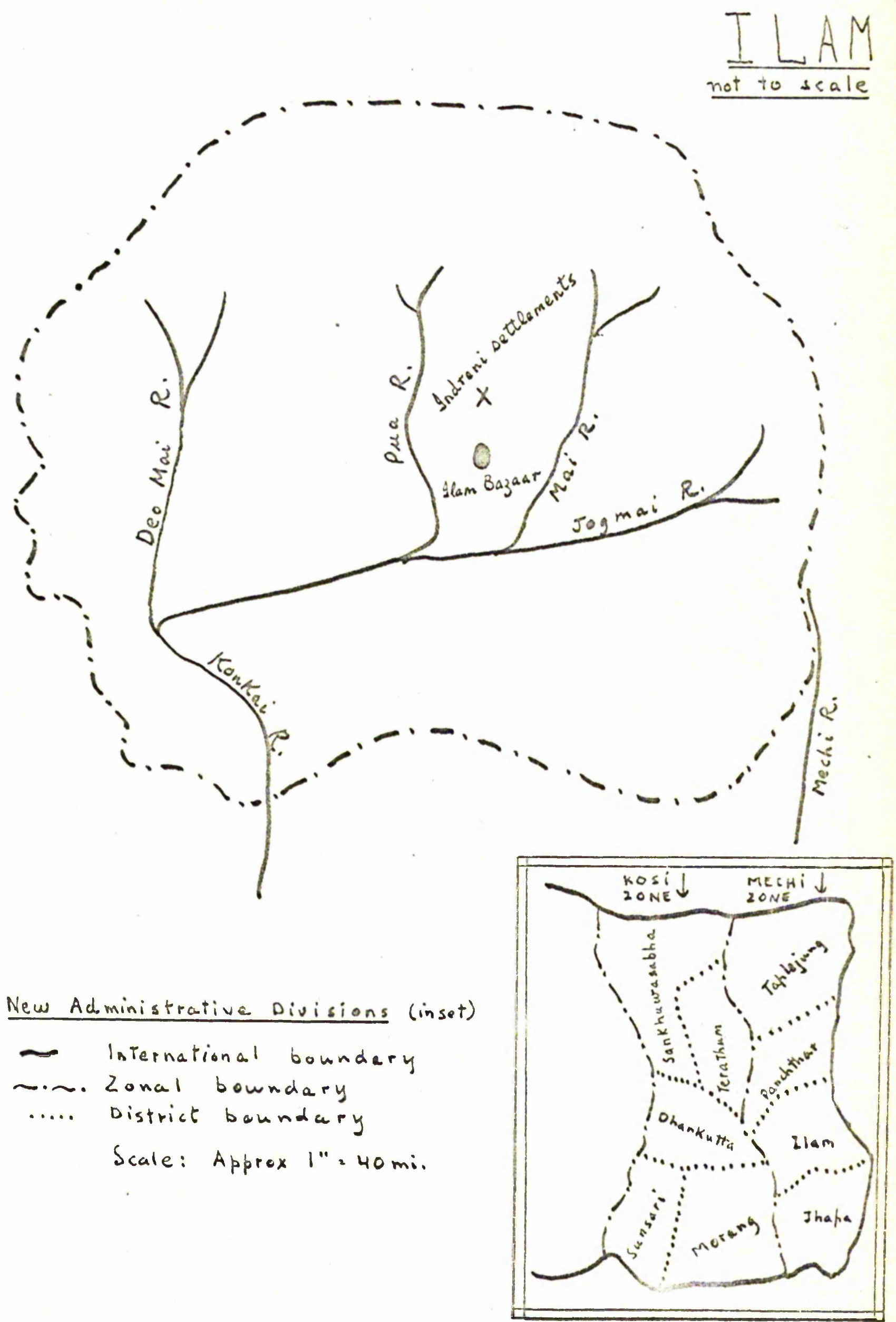


economic aid politichl spheres of Linbu social life throughout ecst liepal. The process way dirtur from place to place, but the substantive pattorn is discernible everywhere.

The remainder of this chaptor presents an environmental, historical and cultured background to the problems with which the thesis is concerned.

\section{The Background}

Ilam District

The settlenents of Angbung, Bharapa, Chitok and Dorumba - which for shortinad purposes I call the Indreni settlement cluster - are situated in the arstrict of Ilam in East Nepal. The greatur part of the distriet falls in the midile raiges of the country, a strip of rugged hills reaching to heights of 12,000 foet above sea level and stretching from east to west along the 500 mile leugth of the country. The hills of Ilaw rise sharply from the Teral to the south, a 20-nilo wide belt of low-lying flatiands which is a continuciton of the Gengetic plain of India.

Ilan encompasses an area of 540 square miles. It is bounded on the east by sukkim and the Darjeeling district of West Berged, while to the west and north lie the districts of Dharikutta and Panchthar. 
The aroe is mainly charactorizud by irregular terrain ana poor soil, Lucositatuly the use of terraces for cultivation. The principel crops are paddy, grown in irrigated fielus (winet) at altztudes of up to $5000^{\circ}$, maize ard ailet, which lattur are gruwn in ary fields (bari) up to 8000 above sea level.

The district of Ilan experieices a moderate climate, temperatures seldom risirg above 85 degrees F. auring the warm season frow April to septeilber, or falling below 45 degrees Fo during the cool months of January and Februery. From mid-June to mid-septeraber the sulth-west monsoon rains persist, and leave a precipitation of some 60". Ilan contains a small basin, aranned by four rivers Mai, Pua Mai, Deo Mai and Jog Mai - which dissect the district into four mein sub-divisions (thum).1

The inaroni settlemerts lie in a contiguous belt elong the ecsterli slope of a $4500^{\circ}$ ridse in the Ilan-Darda sub-ajvision of the district. Ilam-Darda, with an area of 55 square miles, conprises about 10\% of the total area of Ilan district. It is bounded on the east by the llai River and on the west by the Pua River, which rivers meet south of Ilas Bazaar, the district capital, and join with the Jog lllai and Deo Hai Rivers to flow suthward into the plains as the Konkai.

1. Ilan is often referred to as "Char Khola" (Four Rivers). 
Ilew-Derac sub-äivision contains a population of approximately 16,200 or roughly $13 \%$ of the total pupulation of the district. This nakes Lian-Darda the most densely settlod of ILw's four sub-divisions with a ratio of 294.5 persons per square milo as against 235.2 for the district as a whole.

These cure let figures, howevor, and take no eccount of the emigrants who have left the district to settle iainly in West Bejgal, in Sikim, Bhutan, and as far east as Assan and Burma. Althulgh there are no statistios available on emigration from Ilam, nor, indeed, on the flow of einifrauts out of Nepal, the movement of population across tho borders has been foing on for almost a century. Ais official of the adrinistration nutioned an enigration figure of four millions. One author rearks that there are three mildion peoplo of wopali origin reguLenly resident lis liorth Bergat and iorth Assan alone, while arother estiliates that two milion Nepedis Live in India, Sikkin axd Bhutan. 2 According to the 1941 ceisus of Iildia, liepal provided 45\% of the foreign imaigrants into India. As early as 1891, over half the population of Darjeeling wis of Nepali orlgin, and one-third had been bori in Nepal. ${ }^{3}$

1. Patterson, 1962, p.193.

2. Rose, 1963b, p.1.17.

3. OMtalley, 1907, p.43. 
Nepalis have provided the greater part of the labour force for the tee estates of Darjeeling.

To take Sirkinil cine, lïepali imigration into that state begarin the latter half of the 19 th certury and reached such proportions that laws had to be promulgated to check the flow. I stili, by 1951, $77.2 \%$ of the people spoke one of the Ianguages of Nepal as their mother tongue. ${ }^{2}$ The primary reason for this emigration is the growirg pressure on leva. In the aroa of the Indreni Cluster, as in many regions of east Nepal, there is little new jungle to break, or virgin land to bring under cultivation. Land shortage was apparently a problom as early as the 1890s. One visitor to Sikkim at the time remarked of the Nepalis: '.....t is because every bit of the land in their country is taken up that there is such a steady enigration into sikkim. 3

Given the existing level of tochnology and pattern of agriculture, the land is unable adequately to support the growing population. Nevertheless, the fact that over 95\% of the population of Ilam depends for a substantial part of its living on agriculture, the need to obtain land or to retain leinds $i_{\text {in }}$ one's possession, assumes the

I. Nakane, 1966, p.260.

2. Davis, 1951 .

3. Donaldson, 1900, p.208. The extent of land shortage in fact varies cunsiderably from one part of the country to another. In a cominuty in west liepal studied by Hitcheock the problem is apparcitiy not serious. (Hitchcock, $1966, \mathrm{p} .61$ ). 
proportions of a constant aid unrelieved struggle. When there is insufficient land to cultivate, supplementary or alternative sources of income liust be sought. A nurnber of opporturities for wage labour do exist both within ard outside the rural areas. But for those who are unable to take advaitage of these opportunities, the threat of eingration looms large. The decision to enigrate is not taken Idghtly. It meais severing ties with kin - although many retain Links with their kin for some years - ard can lead to ever greatex aifficulties than those left behind, especicliy for the first genuration of immigrants. Nakane describes some of the hardiships faced by Nepalis who come to Sikkim. Many become coolies in bazanr town and hope in this way to eari truligh to purchase laid and settle down in a hanlet as poasants. In her words: 'It normally takes many many years from the tine one Leaves home until the final place for settling down as a peasait is fuund... Some feil to becone peescints and reuain as coolies all their Life. 1

This study will not concern itself with those who have left thair homes in Ilam. But no exaination of sucial life in this part of repal car be fully appreciated without taking into account the ever-present possiblitty of having to enigrate.

Ilam is one of six districts in east Nopal

1. Nokride, 1966, p.255. 
which constitute what is known as Limbuain - the country of the Limbus. Limbuan, Lying east of the Arun River, between the high Himalayas and the plains, comprises an area of appoximately 4500 square linles, or about $8 \%$ of the total area of present-day Nepal.

The Limbus, constituting $1.8 \%$ of the total population of the country, ${ }^{I}$ are generally regarded as among the first inhabitants of east Nepal. Together with the Rais, who, like the Limbus, are a mongoloid people, they are thought to be the descendents of the ancient kiratis. 2 In the Mahabharata, the Kiratis were said to dwell in the eastern Hinelayan regions. In many contemporary government documents the area of east Wepal is still referred to as 'Kirat". The country inhabited nainly by Rais lies in the mid-region of east Nepel between the Dudh kosi and the Arun Rivers and is terwed 'Midale Kirat', whereas the Limbu country east of the Arun River i.e. Iimbuan is called 'Far kirat'.

Nothing is known of the early history of the Kiratis beyond what is found in the Hepalese Chronicles which are by ard large based on myths and legends. One

1. Based on the census report of Nepal, 1952-54.

2. There is some discgreemut over the proper desiguation of the term "kireti". Although most writers iriclude: both Rais ald Limbus as Kirati, Vensittart (1915:7) says that it bulongs properiy to the Rais, but because of intermarriage betwecn the two peoples, he includes the Limbus within the "kirati group". Campbell, on the other hand (1840:95), observed that 'Limbu is a generic term for Rais, lakas (a brench of tho Rais) and 'Kerautis'. Filulily, I. s. Chenjong (1952) suggests that all Wongoloid peoples inhabiting the Himalayas culd parts of SuthEast Asia as well are descendants of the Kiratis. 
Chrouicle, dating from the mid-18th century, speaks of the Kiratis 'who cune from tho esst' and, after concuuring the Ahir rulers, established a dyrasty which ruled the Valley of Nepal thruugh twenty-rilie generations until they were driven out by the Somabansi rulers. ${ }^{1}$ A ivepali historian dates the kirati conguest sonetime during the 7 th century B.C. ${ }^{2}$ As opposed to levi aud kirkpatrick, who estimate that Iirati rule of the Valley exteaded ovex 1000 years, D.R. Regal believes that they mey have ruled for a puriod of 725 years. 3

Iimbu mathology attests to their early settlement in the Himalayas. A Limbu Chronicle relates that during the 6 th century B.C. ten brothers and their kinsmen came from Assan to Kashi (Benares). Driven out by Hindu kings, they went north into the Himalayas and arrived at Phedap in east Nepal. Five of the brothers, having gone directly from Kashi to Phedap are called Kashi 'gotra', whlle the remennirg five, who went via Lhasa in Tibet are known as Lhasa 'gotra'. 4

1. Wright, 1958, pp.65-7.

2. D.R. Regmi, 1960 , pp.59-60. Regini also sugeests that the Kiratis coinquered not the Ahirs but the Neniwitus.

3. Ibid, p.62.

4. Limbus still meintain this alstinction between Lhasa clans and Kashi claus, although the term 'gotra' here has no implications as regards marriage. 
At that time in Phedap, the Chronicle relates, thexe were sight kings, as tho ten brothors and their followers were giver rofuge in those kinglons. After some gunerations their descendants came to be known as Limbu or Yakthumba (as the Limbus refor to thensulves). A serles of repressive moasures designed to thwart the growing power of the Limbus soun led to rebelition. The eight kings were defeatud and the victorious ilimbus resaned the area imbuan. The descendants of the Ten Limbus chose their ruiers, and each was given a portion of Limbuan over which to rule. The erstwhile subjects of the eight Ihedap kings elther fled to sukim or lbocame Limbus' and fullowers of the victorious inimbu rulors. 1

Historical sources on east liepal, although still scaity, bucome more ruliable from the midale of the I8th century. By that timo a nurber of snell chiofdoms which hid grown up in Jinbuan were subject to the Rajput-ruled kingdom of Bijayapur. 2 Both the Ral area of Ifidale kirat to the west, which had a separate capltal at Chaudari, and Bijayepur, with its capital at Moraig, were ruled by separato braiches of the Sen dynesty of Muckwanpur. Linbu leaders held the office of prime winister

1. Quoted in Vinsittert, 1915, p.101. I.S. Chenjong, includes almost the saile accuunt. Only a hardful of educeted jimbus who have access to these printed sources, cas relate this myth in cohereit fashion. All himbus, howver, cre aware of thuir descent from the Legendary Ten Limbu brothers.

2. I.s. Chemjong, 1952 argues that there were a number of indeperadeit imbu chiefdoms which were not subservient to Hinciu kings. 
under the sens nud then followers in the holls furmed the main strengt:- of taese Rajput kings. Iimbu chiefs were apparently not everse to playing off competing Handu Irings to gain their uwi ends. Hanilton recounts how the shift of allegluice from Bijayapur to liuckwaripur by one chief enabled the luuckwanpur ruier to absorb the other kingdom into his domeins. He notes that the power of the kings aid thoir Hindu adhorents was very much limited by the kiratis. The prine minister slgned all comissions and orders, while the king nerety apliod his sect. Furthermore, the former could appropriate $10 \%$ of the total reverues of the Kingdon. I Ailother writer coments: 'the last word Lay wath the Kirati chiefs who more than once cast down the Rajput wing of Bijayapur aud set up mother in his place. ${ }^{2}$ The teduous cuntrol of the sen rulers over thoir hill subjocts led one misslonary resident in the Valley of Irepal in the nidale of the l8th century to refer to the 'independert' intion of the 'Ciratas' Iying to the east of Kathmaridu. 3

Thore appears to be somo uncertenty about the extent of Bijayapur's infiuence in the hild country. The liepali histurial, D.R. Regmi, apparontly following Haililton, suggests that uilt 1 the late $18 \mathrm{th}$ century the Bijoyapur kingdon inclucied as of dimbuan ard that part

1. Hanliton, $1819, \mathrm{p} .147$.

2. Tuker, $1957, \mathrm{p} .42$.

3. Giuseppe, $1790, \mathrm{p} .308$. 
of Sikkin west of the Tista River. ${ }^{\perp}$ Sone writers inply that until tho Gorkha conchest, ald of Limbuail had been a part of Sikin, ${ }^{2}$ while Chonjong notes that during the 17 th contury the sirkimuse hid extended their domains westward and subjected rasy of the chiefs of the northeri parts of Iimbual. 3 Whichever the correct view, what 1 s certain is that Ilam was a part of Sikkin at the tine of the Gorkha invasion. 4

By 1772 the Gorkhas, having subdued the Valley of Nepal, began their cunquest of the kiroti country. In 1774 Ilain fell. 5 The Gorkhas erected there a series of forts to secure commuications with the plains and from which to launch an eastorit offunsive. By 1810, they reachea the banks of the pista in Sikrim. Onily the intervention of the British stopped the Gorkha advance, and in 1817 Nepal's eastenn boundary was put back to the Hechi River, where it has remained since.

From the time of its conquest by the Gurkhas, Ilam, largety because of its naturat boundaries and strategic Locetion, has rumeined a distinct urit of adulisistration. Durins the cuirtor cestury following the 1. D.R. Regui, 1961, p.37; Hanilton, 1819, p.132.

2. See fur excirile, J.C. White, 1909, p.17.

3. I.S. Cherijoig, 1952, Chapter 6.

4. Gurisha was one of the petty kingdons whlch had arisen in west Nepal foldowing the large ingration of highciste Haculas fideuing from north Indic in the wake of the Hoslen invasiun of the l3th century. The reigring Shah kiing of Gorkha took advartage of wars between the ivewer rulers in the Valley of ivepal to further his ow politicui cumbitions.

5: D.R. Regni, I961, p.96. 
comalest, Elithoüh Dhaikutta bccuriv the singest aid most important phian lis ocsterr lepat, aid the headquarters of

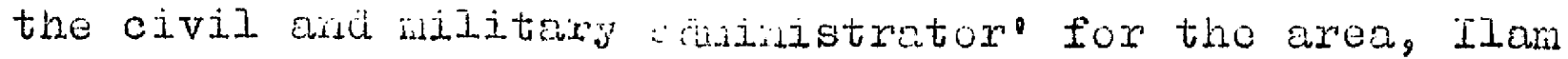
was administerod separateiy by its ow military authorities. ${ }^{2}$ Iis the oridy years or the 19th century Chainpur was nade a separate division to auminister the hill areas east of the Arun River. Until 1890, Ilan was mominally a part of the Chainpur division, although the district contimued to be caninistered by the uilitany, who collected customs and revonues and dispensed justice. ${ }^{2}$ According to Hodgson, the head of the Ilan garrison 'is a captain and has a huncired soldiens under him, with eight artilierymen and one camon of small calibre. This officor is also the civil authority of the aromisseintht, and roises the extraordinary reverue thereof to Het the local expenses, sendine the balance, if any, to hathmeidu. The laind reverue is wholly assigned to has troops in pay. 3

By the wind of the 19th century, at which time

the country was aivided into tharty-eight adrinistrative districts, thu civil authority had largely replaced the

1. Hodgsoin, 1880, p.201.

2. A former goverior of lian claims that the first civil Goversor of the district was appointed in 1817, although there is every iikelihood that at loast urtil the latter half of the igth century military men vere assigned the post. (Cf. Lena, 1959, p.27).

3. Hodgson, $1880, \mathrm{p} .204$. I have seui a recelpt for texes given by the revenue department of the Ilan militia, dated 1873, in which it is speciflcally stated that taxes subnitted 'will be spent as salsury for the militia.' 
military in ILoL. In 1890 Inan was rulovol from the nominal

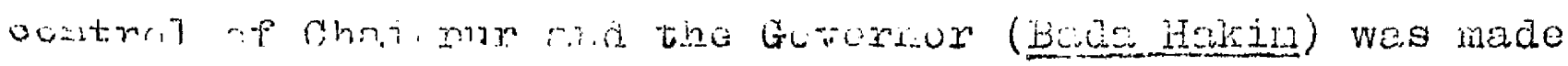
directly respoisible to the Durbar in kathmandu. In that year a nagistratu's court wos ustabilished is the district capital, Itar Bazaar. Oriy reverue netters continued to be haliled by the wilitze uitll about 1910 when a braish of the treasury uffice (nal) was set up in the district.

1951 marked a turing point in the political life of the country. Ustil that time, vepas renained virtually isolated fruin the rest of the worla. Betweon 1790-1950 diplonatic reiations weru maintaned only with Britain and ribot. ${ }^{1}$ Foreigners were not permitted to travel in the hilis, and unly a few privileged westeruers were on occasion allowed to hunt in the Terei, or were invited to visit the Venluy of kathmindu. The cuuntry's Isulation was reflected in the cinost total lack of schools ard of health care, the paucity of roads and other neans of commuication, wid the cibsence of industry. ${ }^{2}$

In 1951 the Rava Resine, which had ruled the country for over a century, was ousted and the powers of the Finarchy restored. 3 in 1952, the Goverment made its

1. In $19 \pm 2$ furmel linirs with China were severed. See Maron, Rose aid Heyllais, 1956, pp. 241-247.

2. In 1950 ebout $3 \%$ of chilaren of schuod age were in schuod: there wexe fewer than a dozen doctors in the cuuntry; there were 120 miles of notorabie roads aud 63 miles of reisway.

3. For a good account of thu events of 1950-51 and following, sce Driver, 1963. 
first cittumpt to ustablish a Panchayat system of local corlilttoes and culuts. In Ilaw, the punchayat lasted four years in the first instajice, wid in 1962, undex a reconstituted systen, wes ruintruduced and was still in effect at the time of fieldworis.

The various comittees established by the panchayat system were grafted oil to but did not replace the traditional adininistrative structure. At the national level, the locus of power in the country romalis the wionarch and has appointecs who head tho various departironts and ministries in the Goverment. Administrution in the hill districts is still effected under the supervision of a Governor appointed by the Crown.

The Governor is primerily responsible for the mantenance of law and order in the dustrict, and retains command of the militia ard police. He also co-orainates the activities of the various local adninistrative departments and initiates such programes and activities as may fall outside the scupe of district departuents.

Traditionaldy, due to poor cummuications between Kathinandu aid Ilan, the Governor's authority extended to all inatters of local aduinistration. And since most epponntees to the post wore close kinsinen of the ruding Reires, their de-facto powers were virtually absolute.

Recunt $\perp$, the boundaries of jurisaiction between the office of the Goverior and the various departments have 


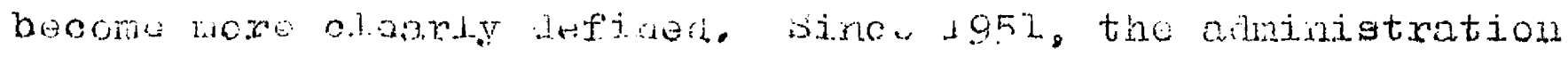
has been reurgatazou to coje whth the expalision of Goverineit services and sctivities throughout the country. Some district branches are row required to repurt directsy to wiaer regional braiches or even to the centrat department in Kathandu. With the graduel unprovenent of commications between hathisilu and the districts, central departments are tending to exercise firmer control over their local branches thai in the past. As a result, the rule of the Governor is more and nore restricted to "genurch supervision" of the various departinints. I

To culscide with the establisbrent of a Pallchayat system in 1962 administrative boundaries were redraw. The country is low divided into 14 'development zones'. Lrach zone is divided into a number of 'development districts' - there are 75 throughout the country - which are further sub-divided into administrative 'Villages'. Together with the districts of Jhapa in the rurai aid parchthar and Taplejung to the lorth, Ilar becane part of the Wechi zone, eastemost of the country's zowal divisions. The estabiishment of rew districts, huwever, dza ilot arfect llan's boundaries. Although the 1962 re-organzation forosees the eveitual chphesis on zoned rathor than on district programing and adninstration, in 1964-65 the prinary developmont entity was stild the distract, which continued 1. Malnotra $1958, \mathrm{pp} .455-56$. 


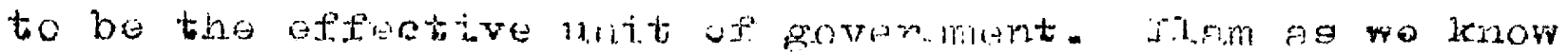
it today hes resained co contant adminzstrative unit since its incorporation into the Gorkhi state sone two hundred years cogo.

\section{The Indrexi Cluster}

At the time of fieldworis the Indreni settlements contained a population of 511. The population breakdown is shown in pabie $I$.

\section{TABLE I}

Indreni Cluster: population breakdown

Angbung

Bharape

Chitok

Dorumba

\section{Brabmins Jaisis}

12

22

23

57

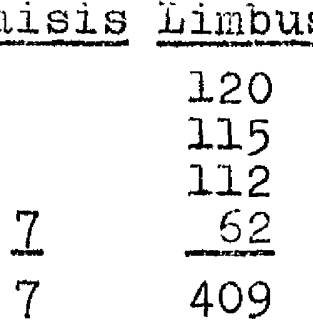
120

115

52

409
Hagars

Blacksmiths

24

$\overline{24}$
1.1

3

$\overline{14}$
Total

120

162

137

92

The Indreid settlements are Located between three and four miles lorth of llan Bazair, the alstrict capital. They stradile a rowa which Leads from the Bazar to a point about four miles iorth of the settlerents where the district's ondy lake is situated. Although vegetation in the area is Iush, especially durine and imodiately following the rans, there is a coispicuous acorth of wovalcha. The dense bamboo forests which once coverud the greater purt of the ridge slopes have been denuded leaving only sparse groves dotted sporaaicaldy arouid the hilis. 


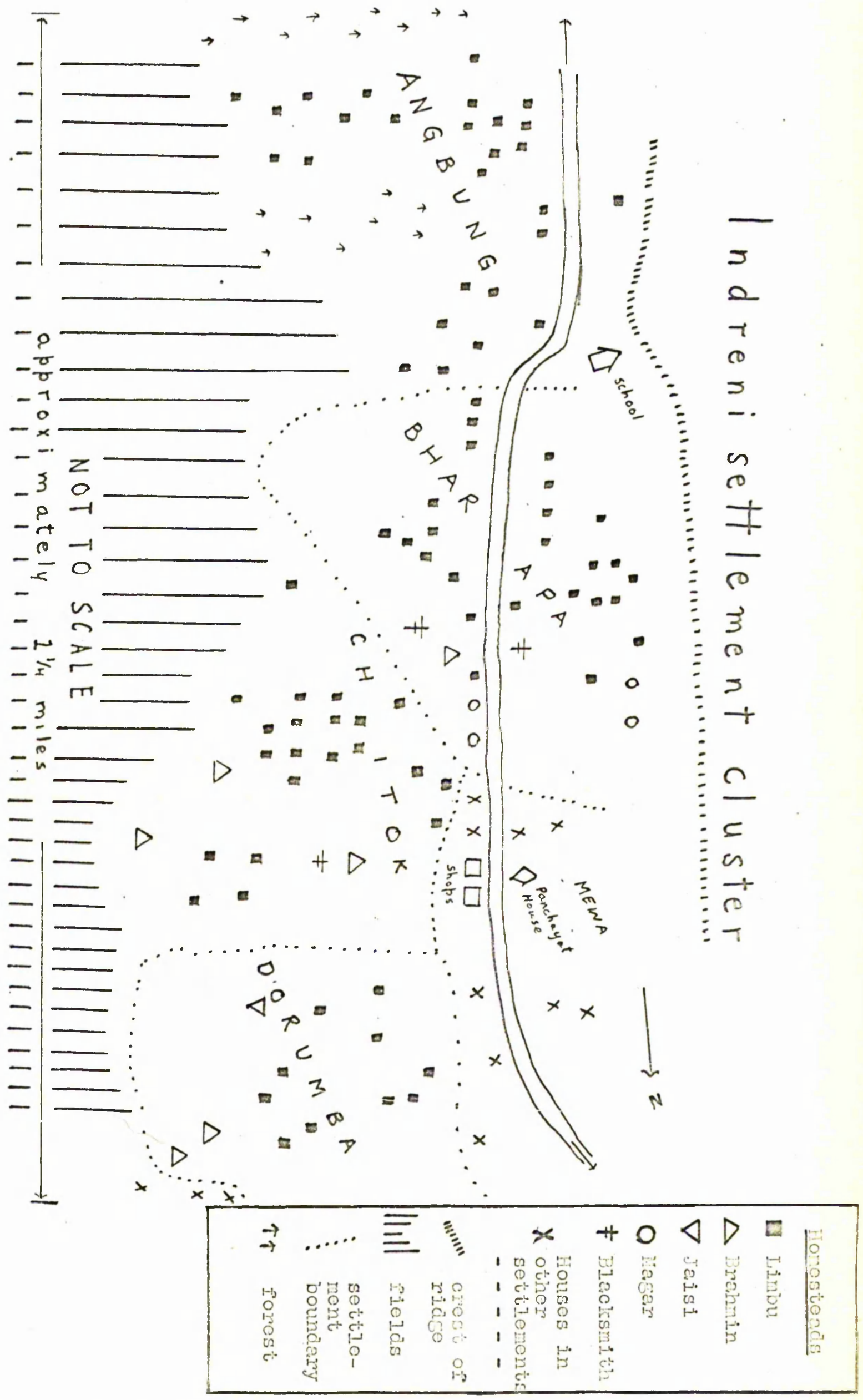


There is no central meeting place where large numbers of locil residents cart gather to exchailge news or relax after the day's work. At one point on the main road to the west of Chitok there are two smadl shops aisd a tiny nut where the paichayat Comittos holas its meetings. At any time of the day a few men are to be found tradirg jokes with tho talkative and witty young proprietress of one of the shops, but only when the Comintee meets are the numbers who cone together more than a handul.

About a mile south of the shops, beside the main road on a smal rise is the only school for the children of the Indreni Cluster and settlements to the north of it. Built of mud and stone, with a thatched roof, the school has three teachers for its five grades. Beside the school there is a lange playground, the only flat spread of land to be seen lif the area, but ondy tho school chilaren use it for exercises or ganes. Nione of the adults in the surrounaing settlements are ever to be seen playing on the fiela.

The Irdroni sottlenuts suffer from no shortage of water for arinking or bathing and every house is within easy reach of at least one water source (dhara). Water is usually tapped from a spring and run through a split bamboo 'pipe' to an area which has beell cleared and laid over with stones. At such water sources women are usually found Wishirg clothes or fillirig coppor or earthon jugs with water, and passing the tulu by exchainging gossip. 
Although several houses in tho Clustor are situated aloresside the naln road, most are set beck a distance and can be reached only by a sories of neirrow footpaths. The houses are coustructod on uilirrigated plots along tho crest of the main ridge at altitudes betweeil 3500 - $4500^{\circ}$ abovo sea level. Vegetablo gardens growile spizach, tomatoes, cucumbers, squash, etc. are located on small plots ajacent to the houses and an occasional baikna or guava tree will be situated nearby.

An area in front of each huuse is cleared and levelled to provide a courtyara, in which most domestic chores are carried out. Oftcu a raised platform on which the househola's maize crop is stored is placed in the centre of the yard. During the dry seasol, men weave wicker baskets, reparr ploughs or pass the tine away in the open courtyerd. Here women pound aud polish rice, wash utensils or brew millet beer. Grains are left to ary on lollg mats of split barabo and rice for the daily moals is wimnowed in the open air.

Unilke the practice followed in some parts of Nepal, cattle and domestic aimals are not kept inside the maill house. Cattie byres, pig ard goat pens are constructed on the edge of the courtyard, whilo chickens are kept under baskets or in other containurs out of reach of preying jackals.

Houses are of varylng constructuong they can be 
roughly classifica into furx mean types. The simplest and least expensive consists of vise stolle ard mud wall with the remailing three wells rade of bamboo strips and mud filding. There is only one roon mosuriug approximatedy $10^{\circ} \mathrm{x}$ 12' which is usca both for cuoking and sleeping. A tiny attic provides just eisough space for storing millet and paday, which are usually kopt in large rectaigle-shaped baskets made of bamboo strips. The rouf is thatched with hay or occasiorally a more aurable grass (khar) growi. especially for the purpose.

A second type is sidghtly langex thar the first, and here ald four walls ere of stone. It is constructed ord a storie foundatiun about three feet is depth. In thas house, too, there las ondy one room anthough il there are maly peoplu living in the house the attic may be used for sleeplng as wed as storage. The ruof is thatch and there is a partly chelosed veraidan at tho frout of the house facilig the culirtyard.

The third type of house is larger than the first two (perhaps $20^{\circ} \times 30^{\circ}$ ) and consists of two storeys in adaition to a sturage attic. The kitchen is numaily on the ground floor, but the inhabitants sleep on buth floors. There meit be al hoc partitions separatile the sleeping quarters of verlous porsors but this is not the rule. In adation to the front verarah there may be a narrow 
balcory on the securd filour. Here, too, the roof is of thatch.

The fourth type is the largest of all (approximately $\left.25^{\prime} \times 40^{\circ}\right)$. Inside, wood pertitions divide the. space on both floors into several rooms and perhaps a seperate kitchen. The porch is completely ehclosed in wood to provide shelter against the weather. There is a tin roof. In none of these huuses are chimeys or proper vertilation found. Whidows are the exceptiun and are usucily covered by woden shutters. As a consequence houses are generelity dark and smoke-filled. The Lower part of the outside walls are covered with red earth aid the tup may be whitewashed with lime. The floors of the Imer house ard the verandah are covered with a mixture of red earth and cow dung cud reptastered at the buginuing of each fiepaii month and on other specicil rituel occasions.

Ever in the rost wel1-to-do house furniture is misimal. Beds are uncominon; peuple sleep on hay or bamboo mat laid unt on the floox. While some of the wealthier houses have chairs, most puople sit on smald rourd nats made of naize coverilis's or on locally woven biakets. Meals are taken seated on such mats ard food is placed on the freshly cleaned flour lis fruit of the person eating.

Since the Parchayat systein is a recent areation the notion of belonging to a denarcated politscal unit such as a statutory village has not yot become an accepted part 
of social life. Traditionally, because of the nature of the terrain and the settlement configuration, there was no concept of belonging to a geographically or socially distinct unit. The characteristic rosidential pattern is one of wide distribution of awellings, a pattern broken only occasionally by small clusters of houses. Instead of nucleated villages, we find aispersed settlentints which merge into one another. The settlemert is never accurately defined. Its name locates a man's place of residence, but buundaries are vague in the fringe areas between settlenents. I have seen documents referring to the same man, living in the border area between settlemcnts and written with his knowledge, citing his place of residence as Angbung on one occasion, Bharapa on another, and a third settlenent outside the cluster on yet another. A brief description of settlement boundaries in the Indreni cluster w1LI ildustrate the residential pattern.

Angbung, the southernost settlement in the Cluster, is the most compact of the four, so that every house is within easy reach, via a network of footpaths, of every other house in the settlement. Argbung has also the most definitive boundaries of any of the settlenonts in the Cluster. It is bordered un the west by the main road to Ilan Bazaar (only one house is situated on the western side of the road, atop a small rise). On the north and east Angbung is bounded by fields, and on the south by a wood. 
It is not completely isolated, however, for the houses of Bharapa contimue along tho ridgo, on both sides of the main roed, from where those of Angbune levve oft'.

There is a wider aistribution of houses ill Bharapa than in Angbung, save for one cluster of six houses to the west of the main road. Whereas the ridge top to the west, and fields down the eastern slope of the ridge bound the settlenent on two sides, it 'fades' into Angbung on the south, into Chitok on the north-east, and into yet another settlement outside the Cluster - Mewe - on the rorth-west.

The residential pattern in Chitok is similar to Bharapa; again with the exception of one cluster of four houses and another of five, most houses tend to be widely dispersed. Residents of Chitok have clear ideas about the boundaries of their settlenent to the east (fields extending down to the Mai River) and to the north (a glen between two hills). The boundaries with Bharapa to the south, and with Mewa to the west, however, are ill-defined.

Houses in Dorumba are more widely spaced than in any of the other settlemcrits in the cluster. Although the boundaries are clearly demarcated to the south (the glen north of Chitok) and to the east and north-west (fields) there is no cloar boundary between the houses of Mewa which extend westward up the ridge to the main road and those of Dorumba, nor between those of the latter and the dwelinings 
of yet another settlemunt to the north-east.

Settlenchts ard nelther exogamous nor endogamous units. Nor are the inhabitants of any one settlenent bound together by common rituals. Because of the necessity of sub-dividing scarce plots, sibling groups tend to live on adjacent lands arid thus to inhabit the same settlement. In several cases, however, siblings do live in different settlements. Moreover, links to kinship units beyond the siblinggroup extend regularıy into neighbouring settlements within the cluster. Those persons who pay taxes to a headnan cre linked across the vague boundaries of settlement. Similerty, mournling obligations on the death of an agnate crystalijze groups without reference to settlement.

In day-to-day contexts, the persons with whon one interacts most frequently are neighbours. A bousehola which runs short of salt or cooking oil borrows from a neighbour; those without a foot pestle for pounding rice or millet use their neighbour's. During the agricultural season leighbours exchange labour. They are the first to be invited to weddings or funeral rites. On warm evenings neighbours gather in each other's courtyards and tell stories or trade gossip. But because of the settlement pattern, a man's neighbourhood does izot always coincide with his settlencit. Those in the fringe areas between settlements count nolghbours on both sides of the 'boundary'. In a seise, then, neighbourhoods are ego- 
centred aid must be conceptualized as a scries of overlapping circles which transcend settlement boundaries, especially whon these are not clear-cut geographical features. There is tio Nepali word which specificaliy denotes those units here called settlemunts. The word 'gaor', usually translated as viliage, is employed in a variety of contexts. It may denote the naned unit of residence, i.e. what I have meant by settlement. Gaon can be employed when referring to the general area, so that a man out for a walk will say simply: 'I am going to the gaon'. The area subsumed by the new Panchayat Comittee is called a gaon although it includes a number of settlenunts. Finally, within the area of any settlenent, a small cluster of houses may be cailed a gaon. Similariy, because the Indreni Cluster contains a majority of Iinbus, it is often referred to as 'Limbu gaon'.

What has to be stressed, then, is the fact that the settlemunt is not a discrete social or political entity. Nor is it a unit in the administrative hierarchy seen from above. The notion of the settlement as a self-aware entity does not exist either in the conceptual notions of the inhabitants or 'on the ground'. 
The Peuple

Prior to aid for some years after the Gorkha conquest Ilaw wis irihabited mainly by Lepchas. ${ }^{1}$ Limbu migration into the area certainly took place before the Gorkha conquest, but was evidently catalyzed by the political and military unrest in other parts of Iimbuan following the invasion. ${ }^{2}$ In adaition, occasional migratory waves from Sikkim swelled the Lepcha population of east Nepal. The inigrations led to intermarriage between the two peoples. Campbel1, writing in 1840 , remarks that - during the last twelve years, since the great bigration of the lepchas from Sikkin to the westward has been in progress, the mixture of these two tribes has greatly increased ir freyuenoy." 3 The almost total disappearance of the Lepchas as a separate group in Ilan would seen to support the notion of large-scale intermarriage. Although some informaits insist that the lepchas were driven out of Ilam by the Limbus migrating from other areas of Limbuan, others suggest that many Limbu clans are in fact hybrid. While the Limbus tended to absorb or drive out the lepchas, other migratory movenunts have given Ilan,

1. Cf.Rock, 1953, pp. 938-39; Nebesky-Wo jkowitz, 1956, p.124; Ollitey, 1907, p.22. In the Limbu Chronicle cited above, it is stated that at the time of the division of ilimbun among tho descendarts of the Ten Limbus, the Ilam area was inhabited by Lepchas.

2. Cf. Phago, 1843.

3. Canpbe 1 i, $1840, p .596$. 
like other regions of ast ivepal, a highly heterogenous character. Although ench of the min tribal groups is identified with e particular area in the hilis, in most parts there is to be found an aduixture of pcoples, generally with the tribe indigenous to a particular area predoninating in that area. Since the dircction of novenent has terded to be from west to east, it is more cominon to find members of groups associated with the westeru part of the country living in the east thai vice versa.

In addition to the migration of tribal populations, large-scale immigration of Brahmins, Jaisis and Chetris from the western regions of Nepal followed in the wake of the Gorkha conquest. These imingrants settled anong the indigenous Linbus, thereby creating a multi-ethnic society in Ilari. In the Parchayat area of Syawa, (which contains the Indreni Cluster) whose heterogeneous population is typical of Ilaw's villages, there are thirteen different groups. ${ }^{1}$ Their numbors are showl in Table 2.

1. Throughout the text, the word "Village' is used to refer to the area urder the jurisdiction of the newly ostablished Panchayst Committee. 


\section{TABLE 2}

Populetion of Syawe VIIlage

Percentage of

Households Population Viliage Population

Brahnin

Jaisi

Chetri

Limbu

Rai

Sunwar

Gurung:

Magar

Tamang

Newar

Blacksmith

Tailor

Cobbler

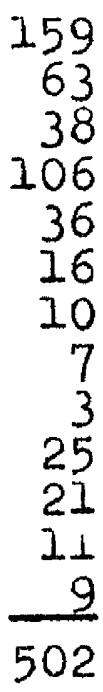

929

359

223

523

220

90

62

42

23

158

95

$\frac{64}{2856}$
$32.5 \%$

12.6

7.8

18.3

7.7

3.2

2.2

1.5

0.8

5.5

3.3

2.4

2.2

The linking together of these maiy groups resulted in the establishment of a caste hierarchy. I Each caste with the exception of the Newars - is associated with one of three main tiers in the hierarchy. ${ }^{2}$ This is not to suggest that nembers of caste groups belonging to one tier always sec those in other tiers as undifferentiated, but only that in certain contexts people are viewed as belorging to classifications larger than castes. Moreover, these are objective divisions in the sense that until 1963, the law

1. This swatgh in teminology from 'tribe" to 'caste" requires a word of explanitioil. Bailey (1961) has argued that the two represent polar opposites along a continum of structural types. In this sense, the limbus are no longer a tribe and rot quite a caste. The latter term is used for the sake of corsistercy, and as a direct traislation of the terin jat, which is used indiscrininately of all groups.

2. The Newars aru geicerally classified separtety, since they are interialdy ranked. See Furer-Heineridort, 1956. 
was applied difforentially on the basis of castes which were for most purposos classified into three tiurs.

In the old Legal Code the Brahmils, Jaisis ${ }^{l}$ and Chetris were designated as 'twice-born' (tagachari) castes. In common perlance, Brahinins and Jaisis, and, less frequently, Chetris as well, may be referred to as 'Bahung'. More frequentiy, the three groups are texwed 'Khas-Bahuns'. However, whereas Jaisis will generally refor to themselves as 'Bahuns', Brahmins numally prefix the term 'Upadiya', denoting a status superior to both Jaisis and Chetris. All three groups wear the sacred thread, a symbol of their high ritual status. Brahnins serve as priests to the three 'twice-born' caste groups, but aside from this, no specific occupation is associated with each group: all are cultivators. 2

Below the twice-born castes in the ritual hierarchy come the various 'tribal" groups. Limbus, along with Rais, Gurungs, Magars, Sunwars and Tamargs are termed (both in the old Legal code and in everyday conversation) 'drirking (matwali) costes'. This refers to the fact that they arink beer aid liquor, a practice forbidden to orthodox Hindus. Ecch of these castes assigras to itself a position in the aidale straturn of the hiererchy not anways in accord with the position it is assigned by other groups. So that

1. These are the issue of uniors botween Brahmin men and Brahmin widows.

2. Brahrins in east Nepai, unlike those in some parts of the country, plough. 
although it is geiuraliy cocepted that drunking castes rank below twice-born groups in the ritual hiererchy, how the former are arranged is a matter of sone uncertainty.

Nore of these groups in the midale tier wears the sacred thread. hor does any follow a specific occupation with which it is associated by tradition. Iike the twiceborn groups, those in the midale stratum of the hierarchy are primenly cultivators.

Fincily come the menial cestes - the 'untouchables' (pani na calne) - who rank lowest in the hierarchy. Regarded as occupying a status below the pollution 'barrier' they are not allowed to enter the homes of those in the higher strate. Although some Blacksmiths, Tailors and Cobblers live in symbiotic relationship to the higher rarked groups, aid perform services for the latter, the majority do not follow their traditional occupations. Again, like most others in the area, they aro mainly cultivators.

This three tier hierarchy of twice-born, 'drinking and unturchoble caste groups was the social basis for and became crystallized through the old Legal code of the country, abolished only in 1963. The law protected the interests of the Brahmins aid other twice-burr castes by making an infrungenont of their exaltod status a crime. Thus an offunce agalust what was rugarded as the sarctity

1. Tailors are also musicians. 
of the caste hicrarchy was equated with an offence against the state.

The hiersichy is bolstered by rigld rules of commensality, such that a person can accept ritually significant foods only from minbers of groups accorded equal or higher status. No mernber of a twice-borr caste wlII accept such food from a meinber of one of the druiking castes in the midale stratum. And no nember of a group considered ritually pure will take any food - cooked or otherwise or weter from an untouchable.

Certain cultural distinctions serve to emphasize the differences anong the principal strata in the hierarchy. Since the majority of inhabitants of the Indreni cluster of settlements are Brahmiss and Limbus, I will orily indicate some of the distirictions between those two groups.

The main cultural criteria differertiating Limbus and Brahmins are race, Ialduage and religlon. Isimbus are of Morgoloid racial stock and have a language of their own which, in the Lingutstic Survey of india is classified as part of the Tibeto-Burmas fanily. I Ir additıon, they speak, with varylıg degrous of fluwney, the Iirgua franca of the country, itepali kura - ar Lido-Aryan toigue. Because of the high admixture of castes in Ilam, ald Limbu men and most women born and raised in the district are required to know lvepait kura and so speak it with esse. It is not uncommon, I. More precisely, limbu kure is one of the Lestern Pronominalizod Group (Austric Influerice), Himalcyan Groups of the Tibeto-Burnan Fanily. (Cf. Chatterji, 1950). 
however, to find women marraed into the Iadreni settlements from limbuan aruas outside Itam whore there is a greater concentratjon of Limbus, unable to converse in Nepeli kura with ciny degreo of fluency. ${ }^{1}$

The Brahinins are associated with the Caucasian or Indid racicit category and speak lvepald kura as a first language. This latter fact, aside from contributing to differences in fluency and styles of speech between the two groups, enables Brahning to communicate more easily with members of the adninistration, most of whom are nembers of twice-born groups. Horeover, since most Brahmilis have some knowledge of Saiskrit, the language of Hindu ritual, they are bettor able to cope with writter ard spoker Nepeli 'officialese' which contains a considerable anuunt of Sarskrit woras. ${ }^{2}$ Some of the implications of this difference in laiguage faclity are discussed in tho last chapter. Although Limbus claim to be Hindus they are, as Balley remarks of the Konds of Urissa, 'Hindus of a different kind. 3 sume of the differeices between the forms of worship of uimbus aid Brahnins are immediately apparent in certain diacriticel features surrounding their respective dwellings. The courtyard of a Limbu house wll iıt coitain

1. According to prolimileny flgures for the 1961 consus, approximately one quarter of the population of Iimbuan claims limbu kura as its mothor torgue. Thu figure for Ilam is about $10 \%$.

2. Limbus speak of 'Bahun kure' i.e. the Langugge of the Brabnins when they necul to refer to Sarskrit.

3. Bailey, 1960, p.4. 
a shrine for the wowsip of a Hindu deity. The presence of such a shrine, usually a smald mound of arth, or oven an empty kerosone tin filled with earth and topped by a few bralches of a tulasi bush, identifies the home as that of a Brahmin. Nor do Limbus follow the Brahminic prectice of propitiating an ancestor god (kuI deota) which requires the setting aside of a special place of worship within the Brahmin home.

The differences in the ritual significance attached to the taking of meals is expressed in the kinds of kitchen constructed by each. The Brahmin kitchen consists of a platform of mud raised several inches above the floor and to which only ritually qualified meibers of the household or their Brahmin guests have access. The cooking stove, too, is of specicil mua and stone construction and both stove aud platform (whlch Individually and jointid are called 'chulo") are required to be re-plastered with a mixture of mud and cow dung after each meal. Brahmin men take their meais only after ritual bathing and while wearing a special white loin cloth (dhoti) which replaces their ordinary clothes.

Iimbus on the other hard, cook on a simple stove consisting of sevural stones or an iron tripod. They eat in their ordinary clothes after washing ouly their hands and face ard 10 special platform is built for cating purposes. 
Distinct dietary prectices arc associated with each coste. As airuady mestioned, Brahmins are teetotallers, whercas Limbus are frec to arink intoxicating beverages. Although some Brainins are strict vegetarians by choice most eat the neat of goats and sheep. Iimbus also eat buffalo, chicken and pig meat, which are forbidaen to Brahmins. 2 Althuugh Brehmins do not raise chickens or pigs, they do keep buffaloes for their milk, curd alid clarified butter products.

Whereas Brahnins worship the universal Hindu partheon, Limbus worship, by mears of blood sacrifice, a host of deities which have no place in traditional Hindu belief. Limbu mouruing practices also differ significantly from those of the Brahmins. To meition only two features: the Limbus bury their dead whereas the Brahmins crenate theirs; and ilibus observe a poriod of three or four days of pollution (dependung on whether the deceased is female or male), while Brahmins consider pollution to extend for thirteen days after death.

$$
\text { Harriage practices, tuo, differ corsiderably. }
$$

Iimbu marriages are performed by Limbu ritual specialists (phedangma) aid require a blood sacrifice. Costs of marriage are burre by the bridegroom's Ianily, ard the cerenony itself takes place at the home uf the bridegroom,

1. Vegetarians ad inon-vegetariain ane sonetines fund livines in tho same Brahnin household.

2. AlI informants ciain that beef was caten by iimbus prior to the nncorporation of Limbuan into the Gorkha jolity. 
before and after which a serios of payments are traisferred frum the groom's to the bride's fanily. Iimbu widows are re-inarried in essuitially the same ceremony as are new brides. Brahnin womer, by contrast, ere married at their natal homes in cermonies coiducted by Brahmin family priosta (purohit) and the narriages thereby made are considered indissoluble. The costs of the marriage are borne by the bride"s femily. Brahmin widows are not re-married.

other differcnces contribute to the identification of two aistinct cultural groups in the region of the Indreii settiements. Limbus grect one another quite distinctly from the way in which Brahmins greet their caste fellows. Greetilig prectices thereby express aut merely differences in kinship norms between the two castes but their cultural 'apartiless."

There are also distinctions in the weys in which merbers of each caste dress. All easteril hill nen wear the same besic costume: a double-breasted upper garment which falls below the waist, and a paix of trousers loose at the waist but taperilg gradualdy so that it is tightfitting from the kneus down. A European style jacket is worn ebove this costume oit dress-up occasions aild a cap which is high on one side and low on the other, is worn on the head. Ald men wear thuse cumponent units of the dress, but the distirction is in the mailier in which the aress is 
worn. In mbus tend to prefur the upper gament to be kneelength, whlle Brahnims wear tho gamoit six or elght inches above tho knees. The rosult is a distrnctive Limbu 'style' despite the sinilarities in the compoient parts of the costume. Limbu womeil are even nore set apart from Brahmin womex. Iike the latter, their head is covered by a shawl. Women of both castes wear a blouse and a sari as a lower garment. Iimbu womer, however, prefer their blouse to be made of velvet - usually black - while Brahmin women generally wear multi-coloured cotton or silk blouses. Limbu womer also wrelp a bright red cloth around their waists in the style uf ais apron back-to-front, a feature which Brahnin women omit. The result is that the caste affiliation of most people is readily apparent by the manier of their dress.

Finally, a word might be said about differences in the "pleasure complex" of the two groups. The most importart aspects of this complex anong the Limbus are drinking and lascing. Willet beer (jar) and liquor distilled from millet (raksi), the two main kinds of intoxicating beverige made and corsuned in the settlements constituto ai integral part of limbu social life. Obensance to headnen is expressed in the presentation of liquor; the request for a girl's hand in maririage is preceded by the offering of liquor: marriage payments 
include large quantities of liquor; the settlement of a dispute between Jimbus is symbolized by the sharing of liquor. Indeed, there is hardy a social event which does not in some way involve the sharing of drink.

The importance of drink is especially evident during rituals which bring together large numbers of people. Marriages and funerary rites are characterized by the consumption of vast quantities of beer. The norms of hospitaiity, too, demand the serving of beer. A visitng kinsman or other guest is made welcone by offering beer in a bamboo container (tongba). I have heard one old Limbu remark: 'Tongba is the Limbu god'.

On the weekly market day in the nearby bazaar town it is not unusual to see a number of Limbus drinking together in ad hoc stalls set up along the main road. Those intent on arriving at the market carly will have a hard time avoiding the invitations from kinsmen and friends to share one for the road.

Another form of recreation which marks off the Iimbus from the Brahmins is the formers' enjoymert of dancing. The iimbu 'paddy dance' (dhan nac) involves a line of men aid worner, hand to hand, in a series of musical challenges and rebuttals, danced and sung in Iugubrious rhythm over many hours and eveil days. since certain categories of kin - especially sglutes of the opposite sex are barred from daicing toguther, dances are usually held 
when visitors arrive from another settiemest cluster. In the Iidrexi settienut dances tare place weekily on market day for the boncfit of young men who want to spend a few hours dancilg with the local giris before returnirg to their homos. The hosts or hostesses are expected to serve beer or liquor to their guests at intervals during the daice. Limbu wedings and other occasions for large gatherings invariably include dances for the young men axd women. A number of major Hindu festivals provide aditional opporturities for limbus to indulge their delight in dalicing. One such occasion is a large four-day fair which takes place at the confluence of the Mai and Jogmai rivers beginning on the first day of the Nepali month of magh (Jaluary/February). The distunction in 'pleasure complex' between the Brahmins and Limbus is made manifest in the varlous ways in which the two groups regard the fair. Although the wain purpose of the festival is sacred, viz. the worship of the Mai River, the Limbus gather in one section of the fair ground asd spend the better part of the time dancing and arinking. For the Limbus this is primarily a secular eveit elabliıg tho young people to neet others from every part of the district at the daises which continue for days.

For the Brahnins the festival's importance is in its sacrod contont the ritual puriflcation obtaned 
by bathing in the holy river, culd the spiritual duty discharged by propitiation of the Rivur Goddess. Consequently the recreational or pleasure value of the festival is inseparable from the sacred value.

This sacred aspect is the focus of all recream tional activities in which Brahmins participato. Irformal groups organized by wealthy Brahnins gather occasionally to sing religlous songs. Brahmin weddings feature stylized singing competitions (silok) - usually recitations of passages from the scicred literature - between the cejips of the bride and groom. Women from the groom's settlemut gather on the night of his wedding (which takes place at the bride's home) to indulge in songs and play (ratauli) - mostly of a lewd nature - at the expense of the bride's relatives. These and other ritual occasions provide the framework for tho Brabrin 'pleasure complex'. The dearth of secular occasions for recreatioual activity aud the prohibition on arisking ard mixed dancing set the Brehnirs apart from their Iinbu neighbours.

Despite their sharling of a comnon cnvironnent ard their fuslori into a sirgie social syston, each caste thus maintains a distinct 'style of 1 ife'. 
Larid Teinre

Those culturcid differcuces are mphasized by the fact that each gruup is associated with a separate kind of land tewure. The inimbus core identifled wath the 'kipat' tenure system, and only Iimbus can own. this kind of land. All other castes, including Brahmins, possess laid under the 'raikar' system, which is the dominalt form of terure in the country. ${ }^{1}$ Both systems exist side by side in the Indreni sottlenonts, as in the entire area of Iimbuan. 2

The raikar system may be described as one of 'state landlordism under which the rights of an individual to utilization and transfer of the land are recognized by the state so long as taxes are paid. ${ }^{3}$ Possession of land under this systom has no reference to the caste affiliation or place of residesce of the individual.

It is unlikedy that the Gorkhas who established the Kingdom of Nepal actually created the kipet systen. As Regmi suggests, the syston is probably 'a relic of the customary land tenure that the Hongolian commuties establishod in the areas occupied by them prior to IndoAryan penetration. 4 The first rulers of the new state,

1. A variety of land tenure forms have boen noted for liepal. Most weru abolishod after the overthrow of the Renas. See M.C. Regmi, 1963, 1964, 1965, for a description of these systems.

2. Iimbus cal, but on the whole do not, hold land under raikar tenure. See Chapter II.

3. M.C. Regni, 1963.

4. M.C.Regmi, 1965, p.86. 
however, confimma the rights of these groups over their lailds.

The term "kipat" itself seems to have originated in the westerin part of the country aud only reached Iimbuan some years after the imposition of Gorkha ruie. ${ }^{1}$ Although today only the Limbus possess this kilid of land, other irdigenous groups have held land urder the wipat form of tenure. What is significant to note is that the Government of Nepal abolished the kipat system iu all areas of the country save Eimbuar. The ripat associated with members of other groups was thereby also abolished. The reasons for this differontial treatment of Limbus, as I show in Chapter III, appear to be Largely political.

The Goverinneit's adoption of a special policy for east NepaI derives from the relations botweeis the Gorkhas and the semi-independent limbu chiefdoms of the pre-1770 period. The incorporation of Iimbuar into the Nopal state was as much a result of liogotiation as of conquest. Gorkha expansion eastwards in the 1770 s resulted in a series of aLiances with potentially troublesome Limbu chiefs flanking then on all sides. In a royal declaration issued at the time by King Prithvi Narayan Shah, the rught of the Limbus to oujoy their traditzonel priviletges and customs was

1. This view contradicts the argument put forward by some writers (Pradhanauga, 1953; I.S. Chenjost, 1961 ) that the term "kipat" appies to laid cleared cild brought under culitivation by Limbus. In foct these writers imply, as some Indreni informonts insist, that 'kipat' is a Limbu word. 
recognizea. In return for their support the Limbus were assured a necosure of interwat rule unäer their chiofs and guaraiteed their rights to aicestrat lands. ${ }^{1}$

1. Royal urder to the Limbus of Far kirat, 1774. Quoted in Regmi, 1965 , pp. 15I-2. 


\section{CHEPTER II \\ LAID A D D DEOCHET GROUPS}

How does an indivadual obtain rights to kipat land? In this chapter I attempt to answer the question by first describing the structure of imbu groups aid their relationships to land. It is then shown how growirg land shortages brought about two kinds of changes in these relationships. The first wes a concern on the part of descent groups to defune their cruteria of memburship more riglaly in order

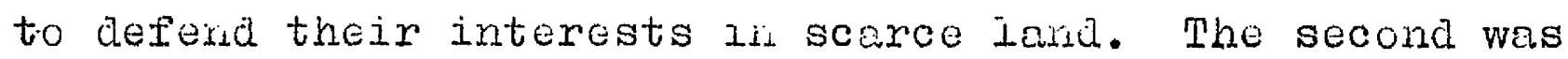
the tendercy for groups of lowest genealogical depth in the nesting hierarchy i.e. the householas to stress their rights to land against those of the wider group.

The Clan

The Limbus are divided into a number of named units which have been referred to as tribes or sub-tribes. This is a trauslation of the tem 'suharg' or 'swaig', although Limbus in the increni settlements romaliy refer to this sub-division as thar, which is the sawe word they use for the exoganous wit, or clar. Vaisittart lists over eighty such suhaig cinolig the Limbus. ${ }^{I}$ wiost, but not all, contain a mumber of clans, although so sirgle informant can 1. Vansittart, 1915, pp. 117-123. 
name more than a few. The suharg Tanling is represented in the Inareni settlumerts by two clans, the Chongbung and the Kambo. These Tenling clans recognize descent from a common ancestor with othor clans in the suhang, but here again they know of only six others, although Vansittart names thirty-eight. ${ }^{I}$ some Chongbung informants clain not to marry with several other Tamling clans, but they contradict one another about which ones. It can be assumed that the clan and rot the suhang is the basic unit of exogamy.

Other suhangs, such as the Nombeke found in the Cluster, have no sub-divisions and so constitute both a suhang and a clan.

Clan menbers explain the rule of exogamy in terms of the belief of agnatic descent from a comon ancestor. But there is no occesion on which clan nembers meet for a common purpose. Nor is the clan a corporate group insofar as naintaining a continulty of possession to kipat Iaind.

Over the years the clan has bocone dispersed, and its segmonts havo cloared and Laid claim to virgin lands in a numbur of areas of eant Nepal.

In much of Limbuari, certainly in Ilam, rights to occupy particutar areas of land under kipat tenure derive not from direct royal grants nur from 'estates 1. Ibia. 
of holding" conferred by supurzor authority, but by virtue of being 'first settiur". ${ }^{1}$ These first settlers, migrating from areas of relatively high population density, or for political or military reasons, led small groups of kinsmen into what was mainly jungle ara staked out clains to vacant areas. Even following the Gorkha conquest the Government allowed that Limbuan was a kipat area, hence Limbus who cleared the land and brought it under cultivation 'by their own hoe' could legitimately claim the land as their owa kipat. In some regions, as in parts of ILam, they may have driven off previously settled lepcha inhabitants or perhaps intemarried with them. The Legitimization by a royal decree of these cicims to land by first settiers usually came much later, sometimes generations after the fact.

The Chongbuigs of the Indreni settlements express clan dispersion in a kinship idiom which designates each settlement cluster knowr to harbour some members of the clan as the place where one Chongbung sibling founder settled after Leaving the original (unspecified) clan territory in the district of Panchthar. Thus, the second Chongbung brother is said to have gone to Jidhpur, a settlement cluster to the south-west of the Indreni settlenents; the thira son unded up in Phungetapa, a cluster of settlements in the western part of the district, and so on. The

1. This notion of 'first settler' asso exists in parts uf Zambia. Cf. C.M.N.White, 1958, p.127. 
Indreni Chongbuness rugerve fur thoir own apical ancestor whose nane, Sai kenba, cais be cited by only a handful of the more articuiate Chongbungs - the position of senior sibling (jethe ) of the original group which staked out lands in various parts of east Nepal.

The justification for the presence of kambos in the Indreni settlements presents sonething of a problen for the inhabitants. Since no other kambo groups are known to exist outside the Indreni settlements, the Karnos cannot claim that they are part of a wider clan. Several varieties of explanation are offered for their presence. One susgests that the kambos are in fact the descendains of the fifth Chongbung sibling who cane to the Indreni settlements with his eldest brother. Another legend relates that the Chongbungs and Kambos were one clan until a severe famine cane upon the land. Some members of the clan ate a species of stinging nettle found in the hills and these people cane to be known as Chongbungs. Othurs ate soil and they becane kambos. 1

A thira Iegend, more commonily heard, ties together elements of the first two with the ecrly presence of Lepchas in Ilam. I quote the version of one Chongbung informant: This was the place of the Lenchas. There was a fish-trap

1. 'Karl' is the Himbu word for suil. The word for nettle (Sikya) bears no similar rulation to 'Chongbung'. 
at the confluence of the pua and liai Rivers. Sorne Chongbungs from Panchthar currived there and asked the Hepchas if they could borrow the fish-trap since they were hungry. The following morning the Lepchas cane to ask for the trap. "We won't give it back", the Chongbungs said. "Why not?" the Lepchas asked, "We'I teach you to make one and you can go somewhere else." But the Chongbungs would not leave. So they fought there. Many Iepchas were killed, but they fought on. They cane to Bharapa (in the Inareni Cluster) and still they fought. Then the Lepchas said: "We won't leave until you eat this soil." What to do? So the Chongbungs sent for a kinsman and ono came from Dharan. 1 He ate the soil, and his descendants became kambos.'

This last legend, like the first, emphasizes the seniority of the Chongbungs in the Indreni settlements. They are recognized as the first arrivals, the conquerors of the Lepchas, and as such the most prestigious of the clans in the Cluster. This position of seniority is expressed in a kinship idiom. They are jetha in the Cluster. The appelation 'jetha' attaches to the first-born, who is entitled to the respect and obedience of his younger brothers. This status is bolstered by the fact that the majority of the Iimbu population of the Cluster are Chongbungs. That the Kambos ate soil is a damning comentary on their prestige as compared to that of the Chongbungs.

1. Dharan is in the eastern Terai just north of Biratnagar. 
The thira legeid also points to the fact that the Chongbung who dia oat tho suil could not nave bacil the apical forefather of the Indreri Chongbungs. On the contrary, it was an 'outsider" who was imported for the unsavoury task of soil eating. And since he lived in the Terai, which is not a part of limbuan, he was probably a wigrant who had lost contact with his ancestral kipat lands.

This tends to support the private speculations of some informants that the Kambos wexe probably outsiders who cane to the Indreni area aftex the Chongbungs, and were granted kipat Land by the latter.

The Nembekes, with the second largest limbu population in the Indreni Cluster, have Iinks with a wider clan unit, but I have not heard any legends dealing with their arrival in Ilam. The two clans with the smallest population in the Indreni settlenents, the Phatras and Syelings, originally settled uxorilocally in the cluster as affines of the Chongbungs. The latter conferred on them kipat grants which are now inherited in the male line by menbers of the two groups.

I refur to a eroup, tho members of which share the seme clan nowe cild who besieve in patrilineal descent from a comon 'first suttler" in tho Irureni Cluster as a 'local clan seguent? A case could be made for using the tem 'maximal Iineage' to aescribe such units since in all likedihood members of such a group are descendants of a 
common ancestor. The rotion is strursthened by the fairly wide spatial distance separcting the newbers of one of the local groups from others beaning the same clan name. There are no occasions on which clansinen in other Localities are invited to particlpate in the social functions of clansmen from the Indreni ciuster. In other words, there is no attempt on the part of residents to maintan active ties with agratic clarsmen living in different areas of Ilan or other parts of east Nepal. This is true of the smallur groups as well, who might be expected to make such an attempt in view of their aomination by the more populous groups. I Nevertheless, use of the term "maximal lineage" to describe such local units would seem to imply ability to demonstrete Links to a common ancestor. Most Limbus in the Indreni settlements can remuiner only the names of their grandfathers. While some are able to remember ties beyond two generations, none car demonstrate agnatic Iinks to the first settler. Indeed, there is sone uncertainty cmong the Indreri Chorgbungs about the idestity of their founding ancestor. As pointed out eariler, the consensus among the nore articuiate minority is that his rane was Sai Kemba. One Literate muber of the group, however, has suggested that one Sanagimba was in fact the first Chongbung settler. The inforncont who suggested this name, however, had come into possession of a document written at 1. See livayer, 1960, ㅅ..167-69. 
the beginning of the 19th century Eiving Sandgimbn and his descendants rights to hold Land under kipat tenure in perpetuity. The incorporation of the recipient of such a royal decree into a Chongbung gentalogy was very politic in view of constant pressures on contemporary kipat owners to present documentary evidence of their rights to land.

Given the fact that beyond three or four generations genealogies tend to become obscure, it seems preferable to distinguish between local clan and lineage in terms of stipuiated and demonstrated descent. ${ }^{1}$ for this reason I adopt the term Iocal clan segrent'for the groups described above. The population of the five local clan segments with rights to kipat land in the Indreni settlements are shown in the following table:

\section{TABLE 3}

Population of local clan segments

Local Clan Segment

Chung'bung

Kanbo

Nerabeke

Syeling

Phatra
Population

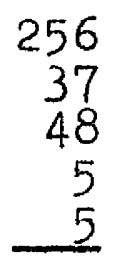

351

By virtue of nembership of such a local clan segment a Limbu obtains rights of ownership ${ }^{2}$ to kipat land in 1. This is the basis for Kuper's aistinction of the two kinds of groups (clan aild lineage). Cf。 kuper, 1947, p.11.

2. The term "uwhership" refers to the possessiun of a certain quantuni of rights in respect of land. (Lloyd, 1962, p.66). What these rights are in the context of the kipat land system will energe during the course of the essay. 
the territory with which it is assuciated. While members of a particular local clan segment share in the bulief of descent frum a comon ancestor with Local segments of the sane clan in other parts of east Nepal, rights to a share in the kipat land of one local group do not Eccrue to nombers of another local group. The bearing of a particular clan neme, in other words does not of itself entitle a limbu to attach himself to any local clan segment whose nembers happen to have the same name. The importance of locality is borne out by the following instance.

In 1953 a man carie to the Indreni Cluster and asked to speak to a Chongbung headnas. He stated that he was a Chongbung and wished to settle in the cluster on kipat belonging to the Chongbungs. He was questioned closely about his kinsmen and it became evident that the man was not a descendant of an Indreni Chongbung. Later the man adnitted that his forebears had migrated to India many generations before and that he no loneer knew whore his kipat was located. He only knew that he was a Chomgbung Liribu, and when he heard that thero were members of his clan in the. Indreni settlements, he had cone in the hope of being given Iond. The hain was refused and went away.

This instance highlights the fact that clan membership is not sufficient credential for pressing a claim to kipat Land. It is juembership of a localised clan which validates a Linbu's right to land. 
In the sunse that a local clan segment retains a continuity of possessiun ${ }^{1}$ to kipat land and also confers (or witholds) nuborship of the group, it can be said to act as a corporation. As tong as agiatic links can be remenbered and traced a nember of a local clan segment, even if living away from the territory of the group, can exercise his rights to a plot of land. Thus the local clan segment must be seen to include those who are not in fact permanerity resident in the group's territory. ${ }^{2}$

The Lineage

When segnentation occurs within the local clan segment, the unilineal descent groups which emurge can be called limedes. lio special term is used for the four to six generational unit which treces genoalogical links to a common ancestor; it is referred to by the same name as a clan i.e. thar or occasionally as 'brothers' (dajyu-bhaj) although the Intter tern can refor to the wider agnatic unit as well. The corporatenuss of the lineago is expressed through the rights it possosses in kipet land as against 1. Sec Fried's definition of 'corporate group' (1957, p.23). 2. Fried spears of corporate finctions of a unilinear kin group which 1 io domant.. o but continuo to exist if strongers who con identify thonsulves as numbers of the kin nay nove in ald enjuy the bunufits of unilinear kin group nenbership." Loid, p.25. 
the rights of the local chen segrient. ${ }^{\perp}$

The Lineags is the core uf anch to a large extent synonymuls with the tax-paying unit. äipat taxes are levelled not on the amount of land owned or cultivated but on households. ${ }^{2}$ Kipct-owning Limbus thurefore pay tax without reference to the amount of land they cultivate or have registered in their names. Insteal, a limbu pays tax as a mexber of a kipat-owning group provided he builds a homostead and establishes a right to a plot of the corporate land. kipat texes are paid to Government-approved taxcollectors or headmen (Subba).

The Gorkhas dia not create subbas among the Limbus. They on 1 absorbed the traditional headmen into the cadministrative structure of the new state. As pointed unt eariier first settiers had staked out claims to land and later their patrilineal aescendants sought confiruation of their rights to hola these lands as kipat. Authentication by Goverrment autonaticaldy absorbed the Subba into the taxcollecting achinery and mate hin responsible for taxes due from lineage netibers.

The first written evidence of Limbu rights to hold kipat in the Irdreni cluster dates to the first half of the Igth century. ${ }^{3}$ The Chungbung Subba was the first to receive I. The lineage is ciso corporate in certain ritual contexts. See Chapter VI.

2. The first Gurkha Kind Hrithvi Warayon whah refrained from taxing the Limbus. Their imanity, huvever, lasted only until the end of the L8th century. Cf.Mi.C. Regini, 1965, p. 105 .

3. The ating tends to confirm the statement by a former governor of Ilar. that onily aftur 1820 were such written decrees issued to Subbas in the district (Lama, 1959). 
a royal decree (1almohar) in 2825; this was followed by similar decrees to the iverimbere subia in 1832, and the Karabo Subba in 1852. Each 'Ialnoherial Subba' - as they are termed - was able to choose a number of lesser functionaries from arnong his lineage mates to assist him in his duties, including those of tax-collection, and the functionaries were granted a measure of tax relief by the Government. ${ }^{1}$ With the growth in numbers of a Lineage, some of these functionaries were able to secure Goverment approval to submit the taxes they collected directly to the revenue office. In this way, new Lineages energed as separate entities. Thus, for example, in 1872 the Chongbung Subba applied to have subordinate tities granted to three of his father's classificatory brother's sons. The eldest of the three later becarne recognized as the first in a line of new tax-collectors for what is now a separate Chongbung Lineage. By this dual process of segmentation and validation of new tax-collectors by Goverment, five Chongbung lineages have emurged. Because of a dispute, however, the details of which I was unable to Learn, the headinan of one of these linecres was aispossessed and attempts to replace him appareitly were not sanctioned by the Governinent. Instecid, his tax-collecting uties were assigned to the Subba of anuther Chungbung Lineage - the one genealogically closest.

1. These functiunaries aro called 'rai', 'karte', 'karbari' arid 'budyauti'. 
The members of the first Linocow nuw recognize the latter Subba as their own headran. Is a result, the Chongbungs now have four recognized tax-culiectons, ecch of whon is regarded as a Subba, although in fact unly one holds the title by official grant of a decree. No special status accompanies either the officially-appointed subba or his lineage. ${ }^{1}$ The differences between the latter kind of Subba and the lesser functionaries is mown, but rights all obligations attending all those called subba are identical. There is also the fact that all enjoy Government apurovad. The dimbus themselves make no point of emphasizing the distinction although the fact may be remembored when it seems worthwhile to do so. In the remainder of the text "Subba" will be used to refer to all Iimbu headmen regardess of the circumstances surrounaing their initial appointment.

The Nembeke have not experienced fission as have the Chongbungs. Their apicel ancestor is traced back only five generations, so that the lineage has renained coincident with the Local clan segmurt. The Nerbeke consequenty recognize only one subba.

The hambo group is divided into two Iineages, each with its own Subba.

The subba, them, anticulates the fissiparous tendencies of the wider ciern segrient. I have heard it stated 1. To receive decree (1almohar) a subba nac to make certain payments. See ij.95- $\overline{96}$. 
that ripat bejongs not to a thar (clan or clan segment) but to a subba.' This remark stresses the corjorcteness of the Lineage as a Lond uwhing group.

Hineages vary considerably in size and extent of kipat ownership. The smallest Chongbung lineage (4) with $5.7 \%$ of the kipat owning Iimbu population in the Indreni Cluster owns $4.2 \%$ of the kipat land, 'I while Chongbung Iineage (3), with $26.5 \%$ of the population owns $14.2 \%$ of the land and Chongbung Iineage (5) contains $18.5 \%$ of the Limbu population and owns $21.2 \%$ of tho kipat land.

The average kipat owning linegge contains only 35.I members (including inmorried wives), although if we disregard the population of the two Lineage groups recentiy settled in the cluster (soe following peges), the average number would be 42.6 jer Iineage. Chongbung Iineages average 51.2, Kambo Iinewes 18.5 and the Nombake group totals 48 persons. The percentage figurcs for tineage land ownership and population are given in Table 4 .

1. This lineage lost holf its penciy lands in a cuurt case about 35 years aso. ïe p. 408. 
TABDE 4

Linovge land umership and population

Iineage

Percentage of

kipat land owned
Percentage of

Kipat-owning pupliation
Chongbungs

Lineage I

Lineage 2

Lineage 3

Iineage 4

Iireege 5

Kambos

Lineege 1

Iineage 2

Nemberes

Phatras and

Syelings
$12.1 \%$

11.0

14.2

4.2

21.2

62.7

11.5

7.8

18.3

15.1

2.6
$11.1 \%$

12.5

26.5

5.7

18.5

74.3

\section{Lineage Lands, especially irrigated fields for .} paddy, are scattired over arl area of severat square miles. Dry plots, situatea on highor ground and on which inhabitants construct thcir houses, though not as widedy spaced as paday lands, tena to be distributed through mone than one settlement in the Indreni Cluster. Table 5 shows that Chongbuld linuage $(1)$ owls ary lena in three settlenents, while sipat ary lands belonging to Chorgbung Lineages (2), (3) and (5) aro found in two settiements. 


\section{TABLE 5}

Pattorn of kipat ary land distribution

\begin{tabular}{|c|c|c|c|}
\hline in Angbung & - & Chongburg Lincenes & $(1),(2)$, \\
\hline in Bharape & & Chongbule Linuages & (2), \\
\hline in Chitok & - & $\begin{array}{l}\text { Chongbung Lincages } \\
\text { Kanbo Iineages } \\
\text { Phot }\end{array}$ & $\left(\frac{1}{1}\right),\left(\begin{array}{l}3 \\
2\end{array}\right)$ \\
\hline in Dorumba & - & Nembekes & \\
\hline
\end{tabular}

The pattern of kipat ary land aistribution indicates that nembers of nore than one kipat-owning lineage are usualiy neighbours within a single settlement. However, lineage land in a particular settlenent is not distributed haphazardy among all lineage mates, but is likely to belong to a branch of the Iineage. So that siblings and extended families incline to sub-divide adjacent holdings and thus to occupy the sane settlement. In some cases land associated with a porticular lineage or lineage branch extends across the vague boundaries of settlemunts, so that nembers of one lineage branch might live in the same neighbourhood but in different settlements.

Iimbus inthout Kipst

The distribution of kipat dry land on which homesteads are erected must not be construed as a complete picture of the distribution of the Limbu population in the Indreni settlenents. The Cluster is also inhabited by a number of Limbus who are not mombers of kipat-owing 
Iineages ari so possess mo owronship rights to kipat land. The existence in the Clustor of non-kipat-owring (Nho) Iimbus has created a situation in which two sections of the population enjoy unequal status on the basis of aifferential rights to land.

The presence of Mio Limbus urges us to consider the relationships between kipat-owning lineages and 'outsiders.' Fomerly, in conditions of land abundance. lineages owning land eithor absorbed outsiders into the group or enabled them to acquire land in other ways. More recently, however, outsiders have been denied access to kipat land ownership as qualifcations for lineage menbership have been more stringently defined. In the following paragraphs I demonstrate how various outsiders were accomodated in the past and how the lineages owning kipat becane less willing, indeed less able, to do so when land shortages reached acute proportions about the turi of the century. Underiying the aralysis is the implication that the Lineage, by exercising its prerogatives to grant or deny land to outsiders reiterates its corporateness in respect of thet land.

I have alreaty aldudod to the uncertain origins of the kambos. ${ }^{I}$ Perhops aue tu those uncertainties, or because of their swell unbors and high ratio of land to population, the kanbos tunded in the past to absorb outsiaers into their ranks. rriox to the turn of the century

1. See above pp. 60-61. 
kipat paddy Lands were granted to untsiders by the then incumbent Subba of Kambo Linecge (I). It is uncertain if or how the outsiders were related to the grantors, but in ary event the geneaiogy was exronged to accommodate the new Lineege nembers (seo aiagram).

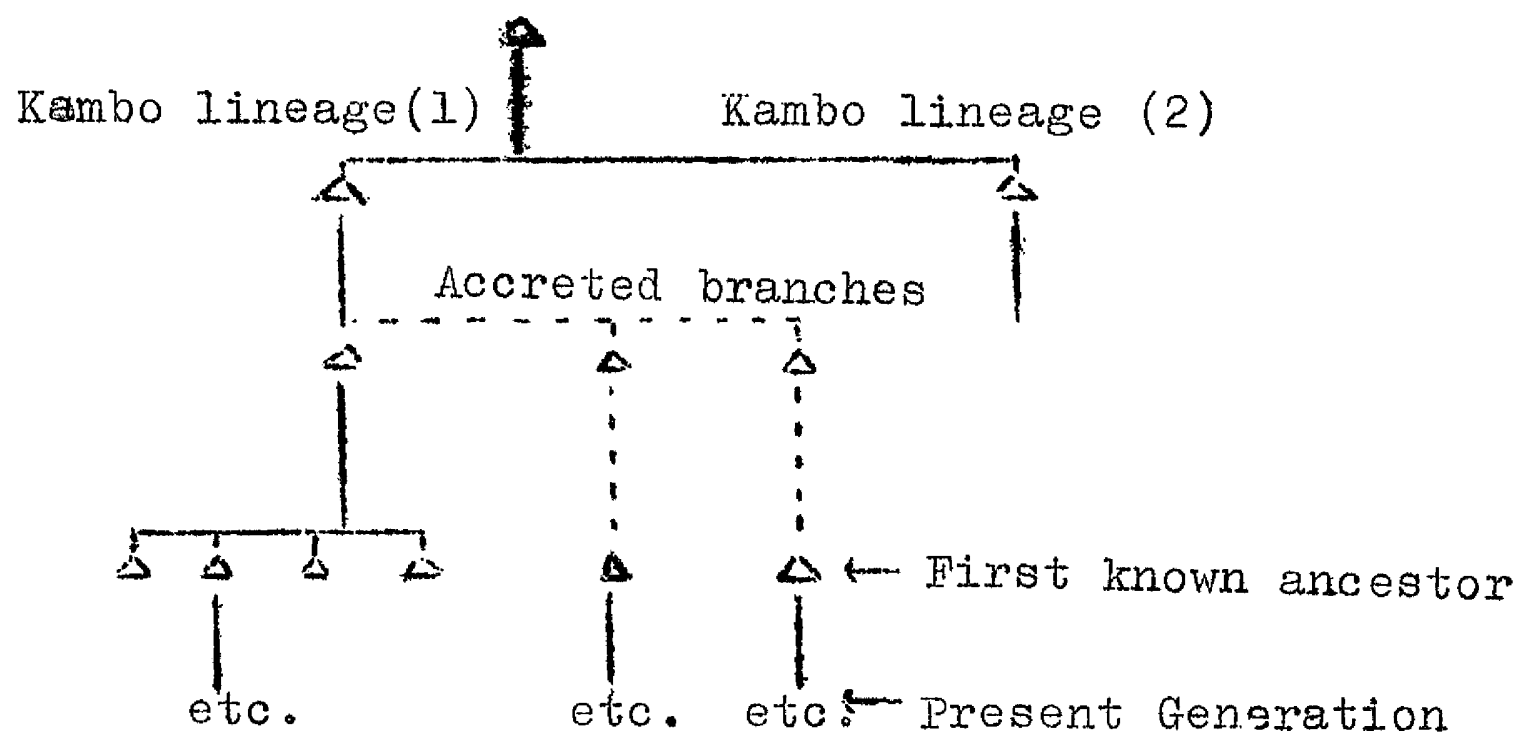

Fig. 1.

Today, their descendants cultivate these lands as Kambos and pay taxes to the present Subba. They also observe puliution on the death of a lineage mate cind in every way act as menbers of the lineage. The only diacritical evidence of their uncertain pedigree is the fact that they possess no ary plots as part uf their kipat estates. Oniy their paduy fields on the ridge siopes below 
the residential areas are under kipat terure.

There is no attempt to deny the fact that two branches uf karno lineage (I) are accretions to the original lineage. On the other hand the othux members of the lineage make no attempt to isclate or in any way enbarrass the absorbed branches. One reason may be that due to death and migration the senior branch of the lineage is now outnumbered by the two accretions. Another reason may relate to the severe impoverishment of the ontire lineage so that no crisis has arisen which mieht test the structural cleavage. Such a crisis, however, did arise anong the Nembeke.

A dispute erupted 1131944 when the consequences of a similar (alleged) absorption threatened the landholdings of lineage members.

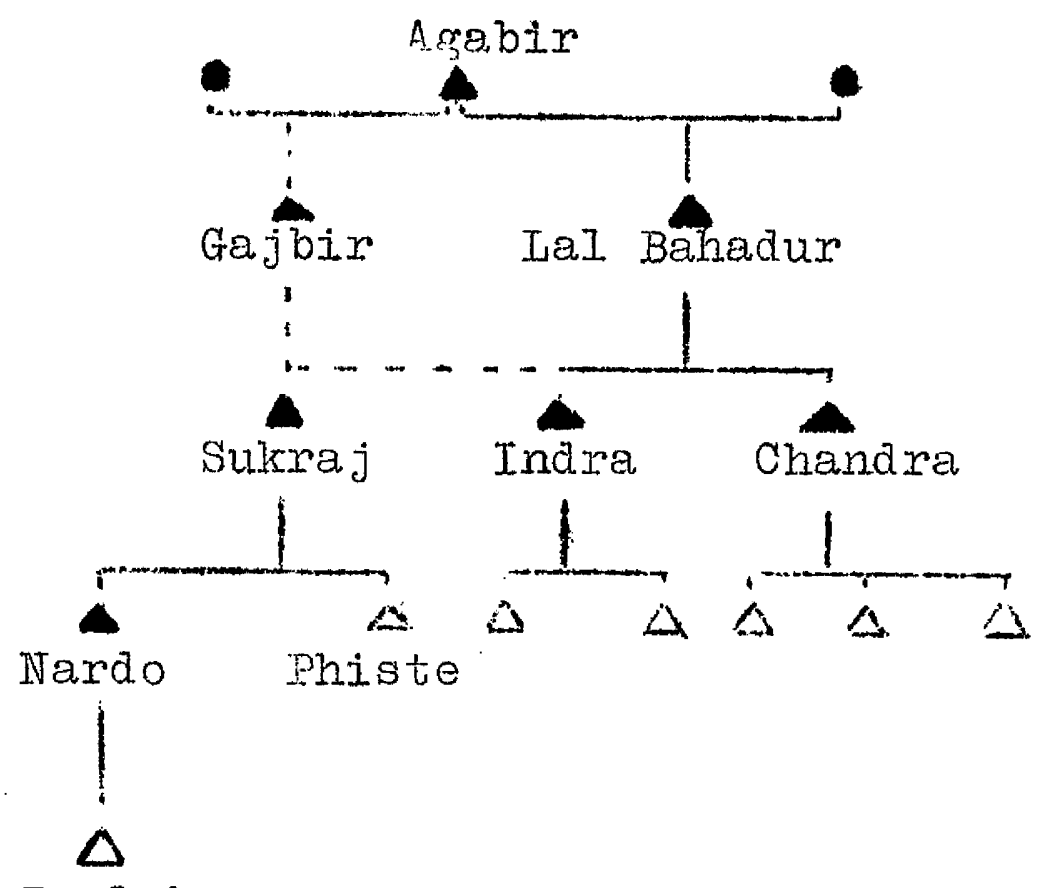

Bagluk 
Iil that year Phiste, tho son of sukraj returned to the Indreni settlements aftor speriling 23 yoers in India. He claimed that his fathur's Lands had been registered at the time of the 1936 reverue settlement in the names of his father's brothors Inara and Chandra and their sons. He demanded the return of the lands. He then went on to argue that since his father had been the ondy son of Gajbir, who in turn had been the only son of the first wife of Agabir, the Iinoage founder, his (Phiste's) branch of tho lineage was entitled to one half of all lineage lands. He claimed that Sukraj had not inherited his due share because a final division of property hod otill not beew madeat the tume of his death. Phiste also pointed out that since his branch of the lineage was descended from Agabir's first wife, it should claim the title of subba as well. But since his father sukraj had rofused the headmenship because his duties as a diviner took him away from home constantly, Phiste would not claim the title. He demended only the Lands which he claimed wero rightfully his.

Since Indra aid Chandra had both died, their five sons canc together to Cefera their interests against the interloper. Their lands together represented the great majority of Linecue holdinss and Phiste's claim to hasf, if. successful, wolld have constituted a blow of the severest kind. But thuy dic not attempt to weny that phiste had a 
right to the Iands of Sukraj. Indoed, they pruved that the Lands of Sukrej had not beon rogistered by Indra and Chandre, as Phiste claimed, but wore in fact in the name of Phiste's brother's son Bagluk.

The probien with which the defendants concerned themselves was Phiste's clain to half of Agabir's lands i.e. half the lands of the lineage. They argued as follows: that, indeed, Agabir had two wives. But that the first was barron. The second then had a son Ial Bahadur and they are his descendants. LaI Bahadur died before the revenue settlement of 1890 which recorded his lands in the names of Chandra and Indra, and the hoadmanship in the latter's name. About this time, they then stated, Sukraj had come from Sikkim and in securching for a place to settle had come to Dorumba in the Indreni cluster since he was related distantly to the Nembekes there. Sukraj had pleaded with Indra to give him some land to cultivate. Inara dic grant him some kipat and male him a Nembeke (1it. 'built a Nembeke'). But even so, they concluded, neither Sukraj nor his son Phiste could now clain to be the co-heir to all the lands of Agair. 'They are not real (pakra) Nembeke.' After a numbor of attempts to settle the matter within the Indreni settlenents had failed the dispute went to court. The court faulted the plaintiff (Phiste) on a technicality and when ho appealed the case, the highor court threw it back to the lower court and asked for a decision 
on the crucial question of descert. Hitigation costs prevented Phiste frun jursuing the mattur, aid shortly thereafter ho returned to India.

From the viewpoint of the defendants it would have been folly to concede the point that thiste was a Iineage member by descent (even if he had been one), and then seek to avoid his clain to a share of lineage lands. They were constrained to attack the very basis of his status in the lineage. Only in this way could they hope to deny him the rights which would have accrued to him as a bona fide member. They could not deny him membership of the lineage since they had observed pollution on the death of Sukraj ond acted in every way as lineage mates to the accreted branch. But they could suggest (or romind him, whichever it was) that he was a lineage member by absorption and not by descent.

A different way of accomodating outsiders was to grant them kipat Lands, without attempting to incorporate the recipients into the kipat owning linvage. The Chongbungs appear to have preferred this method to outright absorption. In the L890s the. Syclings and Phatras, who now possess kipat land in the Indreni Cluster, were given grants in this way. The. Syelings received theins from Chongbung Iineage (2) when the sister of the Iincage Subba married a Syeling man who then settled uxorilocally. The original Phatra recipiont came to the Indruni suttemonts as a boy 
with his mother, a widow, whu rarricd the subba of Chongbung lineage (4). In juth casos these lunds have been registered in the names of the recipiunts and are inherited through the male line. The descendants of those recipients recognize the subbas of the grantor lineages as their heałnen and pay taxes to them. I But the grantor lineages have no right to repossess the land, aithough if a group which received the grant were to dic out, the lands would probably revert to the original grantor - unless patrilineal kinsmen of the deceased could exert a prior right.

It is impossible to presume a single attitude by host lineages to requests fur land frum outsiders. Decisions as to whether such grants would be made undoubtedily depended on factors such as the need for labourers or supporters, the degree of kinship between the host and the outsider, and perhaps on the need for capital, since some of these grants might in fact have been made for finalicial gain. But the chief determining factor would have been the availability of land.

Since rights to kipat land were held by kinship units shaller thali the linesuo grump, kipat srants were in fact made by households and not Lineases. In the Indroni Cluster, in most instances of land grants having been made to outsiders, the grantors were nost often subbas. This is

1. Only in these two cases, as in the case uf the chongbung Iineage without a subba, is the tax-paying group not synonymulas with the Liruage. 
not unusuat in view of the fact that subbas, becase of the rights ettached to headmonship: wore able to accumulate nore lands than their Iincage lates. ${ }^{1}$ Nevertheless, because all lineage mates were potential co-heirs of any one lineage member, no individual or group could aliunate kipat lands without the consent of the entire ineage. Prior to the turn of the century, when land was relatively plentiful, a decision to grant land to an outsider would have met with little opposition on the part of the lineage. The fact that the lineage could deisy the right of any one of its members to rake such grants, however, supported the corporate character of the group vis a vis kipat. During the past 70 years no lineage in the cluster has been in a position to make land grants. Land shortage has led to a more stringent definition of criterid for lineage membership and rights to alienate kipat. ${ }^{2}$

The result is that thore exists jin the Indreni settlements today a catogory of persons without ownership rights to kipat. There are 58 persons in the NKO category comprising $12.7 \%$ of the Limbu populatiun. Less than onefifth are attached to kipat-owning housuholds. Most, however, are the descondaits of men who cane to settie

1. See Chapter VIL.

2. In a sonewhat ancilogous situation, Colson notes that the Nakeh have become concemed to aefine nembership in the tribe nore rigialy since such merbership brins with it political and oconomic privileges on the rescrvation (Colson, 1953, p.80)。 
uxorilocally in the clustor, and have established independent households. Four household heads are members of a NKO lineage (Angu) whose founder, the father of one household head and the srandatier of three othurs, cane to Bharape to marry the sister of the Chongbung lineage (2) Subba. The father of another household head married the grandaughter of the sane Subba. In Dorumba, the Nembeke Subba's daughter was married to a Limbu who, after a decade of virilocal residence accepted the invitation of his father-in-law to settle in the Cluster. His sons are another of the lNKO groups.

But not all IVis Ijimbus in the Indreni settlements are the patrilineal descendaits of men who came to reside in their wives' natal settlements. Two are the offspring of women who married Indreni men and brought their sons by previous marriages with them. One example will illustrate how reluctant kipat owning lineages have becone since the turn of the century to alienate land to outsiders. The case is especially interesting sinco it involves a karao man who was himself the descendait of an outsider absorbed by tho Kambos into their lineage and given a kipat grant.

While Gabe, whose father was accreted to Kambo Iineage (1), was in the amy during the First Wordd war his wifo went cway with anuther mail. Mearwhile, Gabe narried enothor Linbu woman he met in Burma whero he was stationed and had a son by her. Shortiy after, the woman died, and 
when Gabe was givon leave he brought the boy home to the Cluster to be cared for by kinsmen. On Learning that his first wife had gone away Gabe went to hur matal settlement to claim compensation. When he arrived he was met by the woman who was at the time visiting her natal home. After some pressuro by the woman's kinsmen Gabe agreod to waive his claim for compensation and insteal to take the wonan back with him. He agreed also to allow her to bring with her the son she had had by the other man. In the ensuing years she produced two more sons for Gabe.

Although the son of his wife by the other uan became a part of Gabe's household and was addressed by the kinship reference for eldest son or brother, he was not absorbed into the Kanbo Lineage. The lineage affiliation of the boy's genitor was remembered and his rights to kipat land were considered to exist whexe those of his genitor did, but not in the Indrerij settiements. When the boy grew up he chose to renain in the Indreni ciuster and not to. return to his kipat. Today, his son, Dhaman, is head of a household in the Cluster, but, like his father is not a Kambo and has no owitership rights to kipat land in the Iridreni settienents. The position was aranatised when a neaber of hambo Lineage (1) died in 1964. Dharman took as full a part as any lineage member in the various activities consequent upon the death of an agnath. But when it came time 
for the purification rite to bo purfurmed Dhandin had to stand aside. Lineage members bunched tugethor facing the ritual specialist, and, at a particular time, carie forward to touch salt and oil which rendered then de-polluted. Dhannan could only stand close to the group but not mingle with it, nor could he turch the holy foods.

'He isn't polnuted when one of us aies, and we won't be poicuted when ho dzes. His own 'brothers' would have to rourm him, " stated a Kambo spokesman.

Ideally, overy binbu knows where his kipat is situatea. Several NkO groups, only one generation removed from their kipat lands stild retain links with aginates and even visit these kinsmen on occasion to take advantage of financial benefits accruing to kipet owners. ${ }^{I}$

But links to kipat fade as prolonged residence away from ancestral lands leads to the sevorence of contact with agnatic kinsmen. Some NkO groups in the Indreni settlements have no precise knowledge of where their kipat land is Located and have lost contact with patrilineal kin. The Angus for exanple, are aware that their ancestral home is in a region some thrue or Pun days away from the Cluster, but have aroped all ties and probably could not exercise a clain to thuir kipat even if it could be located. Tho uwnership of kipat carries with it prestige and muburs of NkO Linedges in the Indrert settements are 
quick to refor to the fact that thoy too have kipat somewhere, ever if thoy have nuile in the Indruni cluster.

During the early puriod uf lis fiuldwork, when I was coldecting genealogies, on severat occasions lilubars of NKo groups attempted to conceal their lineage or clan affiliation. In every case they insisted that they were Chongbungs and only later admitted that they were members of NKO groups whose kipat lands were in fact somewhere else.

For a member of a lino group, there are two weys to obtain land for both a homestead and cultivation. The Iirst is to jrovide creait to an owner of kipet land in return for which rights to cultivate a plot of land are granted. This kind of usufructuary or possessory mortgage (bhog bardhaki) is the most common method used by ivio inhabitants to gain access to land, ospecially irrigated fields for packy. Five who homesteals have been built on kipat ary land taken under mortgage in this way. A certain degree of security attends the homestead on this kind of land, since once it has been built the owner ${ }^{\text {I }}$ could not easily evict the inhabitant. But the security extends only to the ared on which the homestuad stands, and not to the cultivable plots which may surrcund it, so that both irrigated and unlrrigated lands on which homesteads are nut constructed cen be re-possessed at any time (arter the

1. Usually, but not always, a descondait of the host huusehold which cilabled ar outsider to settle uxorilocally on its Land. 
annual harvostj by rejaymunt of the murtgagu. For the inko Iimbu thas means air anost contimal state of insecurity on the land. One Angu put it this way: oThey (referring to some Chunebungs) are ownors of kipat (kipatiya) but I an only a Iimbu. My kipat is in ancther place. Here I live with my maoli (mothor's natal group). I have ro land of my own, ondy land taken under usufructuary mortgage. If my debtot returns the molley to ne and takes his Iard back I would have only my homestead plot (ghar bari) Ieft. I would have rothirg.'

This irsecurity renders those without kipat land, as I show in Chapter VI, economically the nost vulnerable section of the Limbu population. The almost total lack of land to spare by $k$ groups, Eveil to give under mortgage, would seem to be affecting uxorllocal residence. It apsears to be sIGliflcant that all NKO rosldents Living in the Cluster are at least one genuration removed from the first uxorilocal settlor. In other words, durlig the last quarter of a contury, no outsider has beex accominodated in the Inarexi settlemuts ma any menrer whatsoever. Land shortage has virtually obviated any possibility of uxorilocal resiclorice.

Ore of the ways in which IIKO groups have attumpted to renforce their position is by arrardging marriages within the Clustor. Although marrieges with ko groups is preferable, the degrees of prohibited marriage and considerations of 
stetus lo nut alweys make such matches possible. As a result, many narricges aro wath simlardy placed ino groups in the Indreni sottlenonts. Of seven oxtant intra-Clustor marriages, five involve partners who are of Nho status. Although the numbers are too small to be of any statistical use, they do point to the possibility that intra-NKO group marriage is one way of fortifying a shaky position in the settlements. The fullowing diagram shows how one inlo group, the Argus, have married with other groups in the cluster.

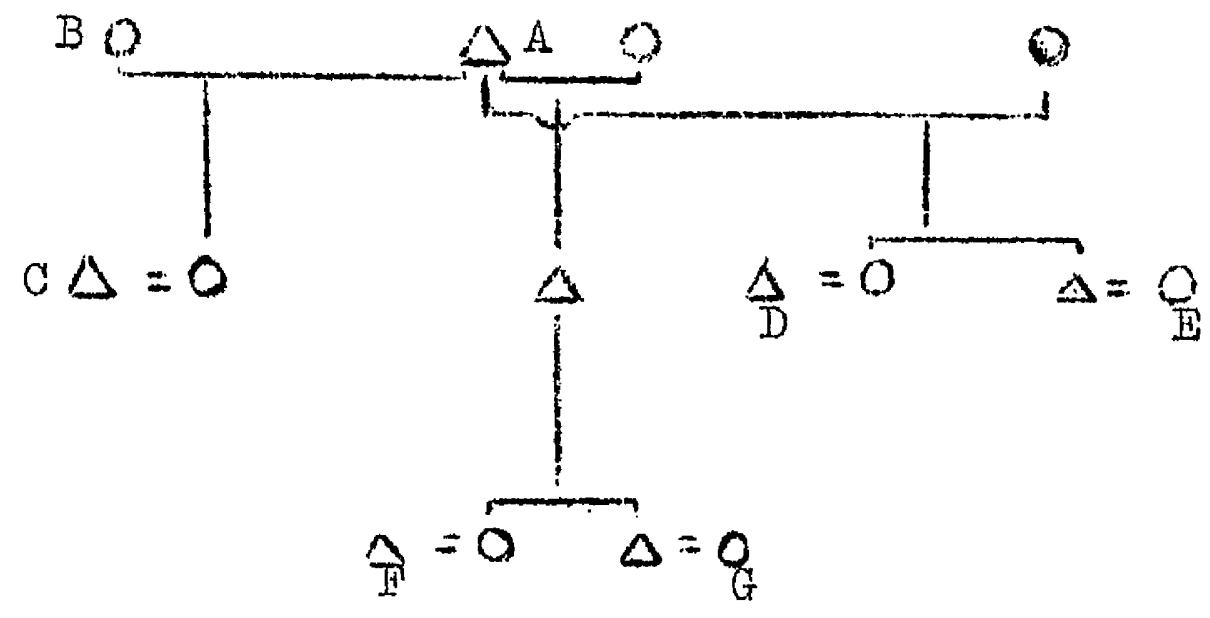

Angu - part genealogy

A married B, a Chongbuisg woman of Bharapa; settled uxorilocality in Cluster.

C - a kipot-owilns Phatra uf Chitok

$D$ - a kipat-owning Chongbung of Angbung

I - a Chongbung womar of Bharapa

F - a won-kipat-ownirg man of Chitok

G - daughtor of a noll-kipat-owning man of Angbung.

Fig. 3 
Tis tho part gencalogy showa kbove, within two Angu gencretions, oxcluaing that of the first uxcrilocal settler, the Angus heve marricd within the Cluster five tumes. They have given women to Ko groups twice, to a Nko group once, and have taken one woman from each kind of group themseives.

I have referred to one way in which NKo Iimbus can gain access to land. There is another way as well, and this is tu purchase raikar laind in the open market. Ralkar land can be bought and sold in a ramer akin to western freehola. Moreover, raikar land has no reference to the caste affiliation of lts jwher. Unilike kipat, which can only be owned by Limbus, raikar can be owned by anyone, including Iimbus.

Nolue of the Nko residents in the Indreni settlements have been able to afford irrigated raikar fields, although several own small raikar plots on which hornesteads have bec. built. Descendarts of the first Angu settler in the Ludreni Clustor, for example, now Live on raikar land which he purchased with monies earnod from service in the local militia in Ilan. Only one other Mo househola, in Dorumba, lives on a tiny plot uf raikar Lana purchased by the Nembere Subba an given to the present household: head's father when he cane to settle in the Cluster after marrying the Subba's daughter.

Sevoral ko householas have, in addition to their kipet holdings, a few dry land raikar plots. The outsiders 
Distribution of dry lands in the Indreni Cluster NOT TO SCALE
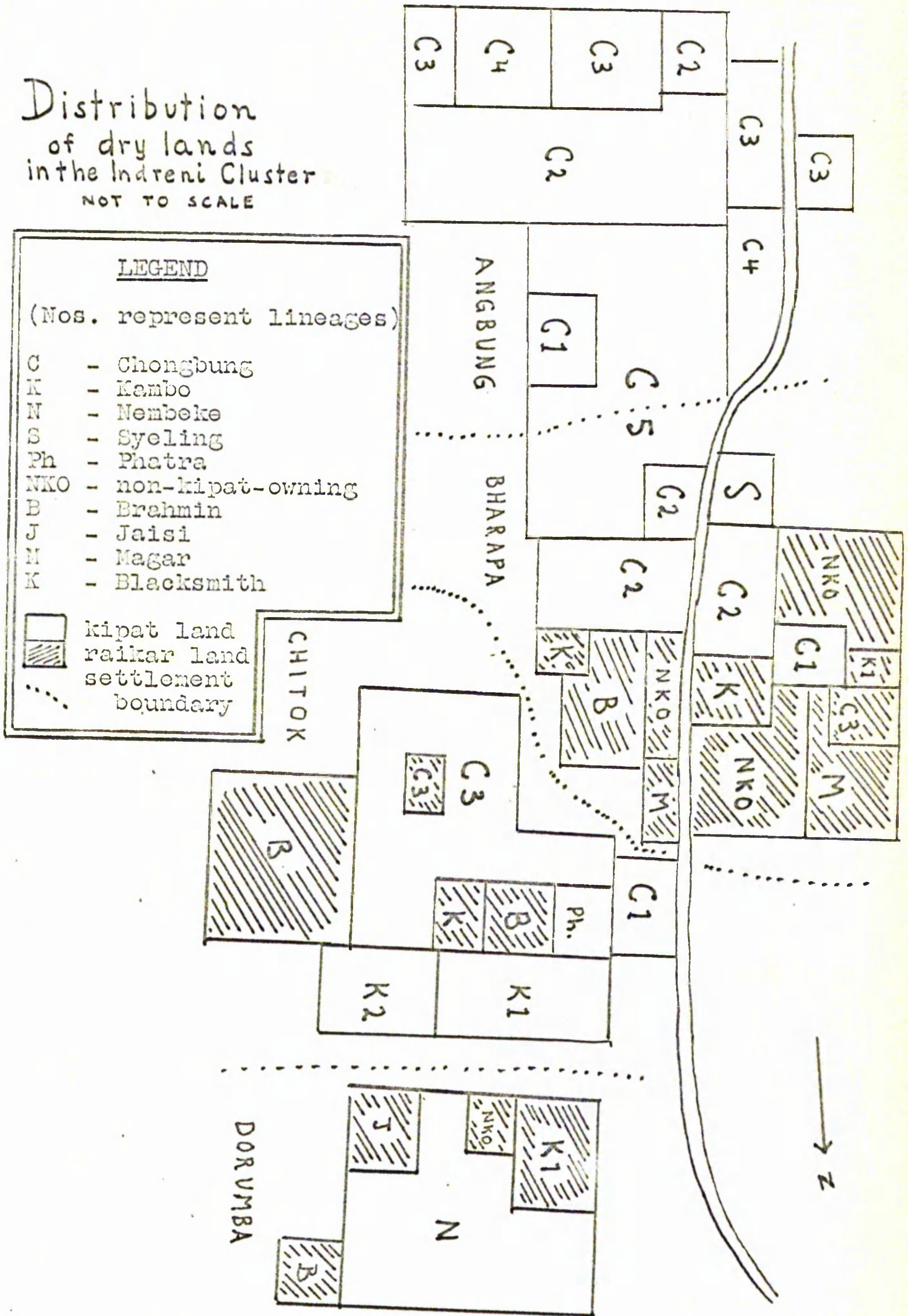
who were absorbed into a hanbo Linese and gIven kipat paddy lands but no ary flulas heve built homoteads on raikar plots purchased by their forefathors.

By and large, the hish costs of raikar laid, and the high taxes paid on this kind of land as cumpared wath those for kipat place it out of the roach of the great majority of Limbus in the Indreni settlements. As a consequence, with few minor excoptions rotod abovo, raikar land tonds to bo assciatod with non-imbu sections of the population. The map on $\mathrm{p} .87 \mathrm{a}$ gives a gonural picture of the distrubution of homestead sites in the Indreni settlements It will be seen that the non-imbu residents of the Indreni Clustor are settlod intersticlaily among the Limbus, although of course unly on raikar land.

Individual Kipet Rights

As we have seen, an individual obtains rights to kipat land by virtuo of membershij in a patrilineal descent group. These rights cre secure if the individual continues to recogilizo his limoage memborship and alteruatively, to bo recognized as a kinsman by Linedec matos. As long as agnatic links are ronubored a mon retains his right even if he resides away from the kipat territury. In this suise, thers, the kipat land can be said to bo 'uwnod' by individuals who enjoy complote security uf teiure, subject only to 
certain overriang nignts of tho descent group. I The individual's prerogatives are reinforced by the fact that for the pest seventy years the boundaries of estates have been fixod and titles registered. This has further obviated the individual's resporisiblitty to reaffim constanty his membership in any group wider than the household.

Formerly, there were obligations to reassert Iineage affiliation by demonstrating allegiance to the Subba. It was necessary to do so because of the latter's greater command of land resources tham his dopendents. ${ }^{2}$ Most Lands which had been vacated or on which taxes had not beenpaid tended to revert to the subba. Although comeirs could clain the right to take these larids, the tax burden which they woula have to assune at the same time prevented many from exercising their claims. Horeover, since the Subba had access to local officials by virtue of his position as headman and was usually in a finarial position to afford the taxes himself he was favourably placed to assure rights to these lands. In such circumstances, an attentive kinsman might hope to be granted a plot when the need arose, or perhaps be assisted to piy his taxos by the subbe in the event of possible defaut and so retain tho lands in his possession.

1. The systen (called 'raibandi') whereby Lineage land was redistributed periodicaldy to lineage membors was apperentiy practiced by kipat owners in some jarts of Nepal, but never in Limbuan. (Cf. M.C. Regmi, 1965, p.83).

2. A detailed description of the subba's changing rights and obligations apoars in Chapter VII. 
Lond shortate his dissipated whatever advantages the subba onjoyed in respect of land. In the unusual case of Land boing abardoned novedays there is no question of its revorting to tho subba. Taxes are no lonser an obstacle to potential co-heirs, so that these lanas pass directly from one inciviaual to another without any intervening authority. And since the individuat is, first of ali, a member of a household, this mesis that the latter unit has become the group with the greatest interests in land. Stated otherwise, there has occurred a shift to the household of rights previously monopolized by the lineage.

The foregoing aralysis of land-owning groups, and of the changes in their modes of accomodating uutsiders as well as of the shift of importance away from the wiger kin group towerds the household as a kipat-owning unit has beer predicated on the transition from abundance to scarcity of kipat land. By scarcity of land, three things are implica. Firstiy,population growth has increased the pressure on land resources. Althuagh figures for the period prior to 1952 qre based on unofficlal estimates, they indicate that botween 1920-61 the popuiation of Ilam increased by approximately 40\%. I Between 1952-4 and 1961 the increase was $8 \%$. Although no seperate statistics are available for the Iimou sector, there is no reason to suspect that their 1. Landun, 1928 (vol. 2), ipp.256-257. 
rates of growth huve not kept pace with those of the remainder of the population.

Secondly, the amount of kipat land owned by Limbus has dininished over the past century. And thirdly, Limbu access to the productive capacity of their remaining kipat lands has been reduced due to heavy mortgaging. The latter manifestation, itself an outcome of the first two, will be discussed in some detail in Chapter $V$. The second trend has come about lergely as a result of the Goverhment's kipat policy. It is thereforo necessary to consider this policy in order to understand the background to the land shortages which developed towards the end of the 19th century and which had the kinds of social repercussions already noted. It will then be appropriate to consider the structure of the Limbu household in the Indreni settlements. 


\section{CHAPTER III}

\section{IAND AND GOVERTHENTS}

By confirming the rights of Limbus to hold

land under kipat tenure, the Government by no means abrogated its own rights to determine the course of events in its easternmost region. "The policy which came to be followed by successive administrations in Kathmandu was based on the containment and reduction of lands under kipat tenure and a corresponding conversion of these lands into raikar tenure. The results of this policy are evident in Ilar. In the district today, only $39.7 \%$ of irrigated lands (khet) are under kipat tenure, with the remaining $60.3 \%$ under raikar tenure. In the Ilam-Dardo sub-division of the distrilct the figures are $40.5 \%$ under kipat and $59.5 \%$ under raikar?.

Following the incorporation of Iimbuen into the Gorkha state, Kathmandu's polfcy vis a vis the Iimbus became double-edged. On the one hand, it sought to

1. Since dry lands are not measured, there is no way of knowing whether the proportions of rejker and kipat are the same as on irrigated lands. There is no reason to believe that the proportion of raikar to kipat is any different for dxy londs. 
placate the Iimbus, ever jealous of their rights, by providing sareguards of their land holdings. On the other hand, Kathrandu lost no opportunity to reduce the area under kipat tenure and concurrently increase that under raikar tenure. The first moves to reduce the amount of kipat land took place soon after the pacification of Limbuan. The Gorkhas apparently dealt severely with those sections of the Limbu population which had opposed them during their march eastwords. One Limbu writer estimates that some 32,000 Iimbus fled. in the face of cruelties perpetrated by the Gorkhas on thase suspected of having aided the sikkimese? Buchanan also mentions that large numbers of hill people fled as far as Furnea in India to escape the invaders ${ }^{2}$. Many returned after assurances were given by the Government that the exiles could come back to their homes and lands, to enjoy the same privileges as those limbus who had not fled. But they discovered on their return that in their ebsence the Government had confiscated their kipat lands and allowed thern to be taken up under raikar tenure by non-Iimbu immigrants from the west and the plains of India who hed entered Himinan in the wake of the Gorkha army. Some of the lands were restored to the 1. Phago, 1843. 2. Buchanen, $1928, p .257$. 
retuming Iinbus as kipet, but the immigrant settlers could not be turned off the major portion of the lands they had begun to cultivate?

The arrival of non-limbu settlers was part of a policy instituted by Kathmandu encouraging the immigration of other peoples into Limbuan. Iimbu Subbas, for their part, were urged to settle these immigrants on their lands. Since Isimbu land holdings were extensive and there was a need for settlers to provide both labour and a following, the Iimbus gave away land grants called 'soranni'2 to these immigrant settlers. Recipients of these holdings gave away sub-holdings to other imigrants out of lands which they could not themselves cultivate. Until 1886 these lands continued to be regarded as kipat. In that yeer the Government introduced legislation which in effect allowed non-Iimbu settlers to convert into raiker tenure all kipat Iands which had been or would in future be granted to non-Iimbus by their limbu owners ${ }^{j}$. Thus

1. Order Regerding Restoration of Tipat Lands in Pa.11o-kirat, 1881. See M.C. Regmi, 1965, pp. 88-89; 97.

2. The term 'soranni'is a controction of 'sora anna' meaning sixteen annas or one Indian Rupee. Nost Limbu informants insist that their forefathers gave their lands to immigrant settlers for this meagre amount.

3. M.C. Regmi, pp. 97-98. 
at a time when lana shortages were beginning to be felt by the Limbus the Government effectively dissolved whatever rights still remained to the Iimbus in the soranni holdings they had given away. These conversions were regarded by the Government as immutable. Once registered as raikar, land formerly held under kipat tenure could not be node kipat agoin. On several occasions Iimbus petitioned the Govemment suggesting that any kipat lands which had been converted into raikar and later re-purchased by Limbus should be occupied again under kipat tenure. The argument was that in any case the land had once been kipat ${ }^{1}$. These requests were turned aside by the Govemment which would. entertain no reversal of the kipat-into-raikar trend they had initiated.

Other aspects of Govemment policy designed to reduce the area under kipot tenure concerned the appojintment of jubbas and the registration of land. titles. In official subba, on appointment by royal decree was required to pay an initial fee of $R_{5} 52^{2}$,

1. Petition of the ijubbas of Ilam, 1951. -.1so, Report of the Muluki Office, 1947.

2. One inepali Rupee equals opproximately one shilling. 
which represented a considerable sum in the past. He was also required to surrencer sixty muris ${ }^{1}$ of paddy land to the Government as rairar. If the claimant could not afford this anount he could choose a lesser title (rai) which would be granted after the surrender of half the amount taken from a subba. Although these regulations still exist, the dearth of land to convert in this wey makes the creation of new Subbas an extremely rare thing. In the Indreni settlements the only Subbas who surrendered land in this way (and are thus 'official' Subbas) were the three original grantees of royal decrees in the first quarter of the 19tb century ${ }^{2}$. Government insistence on documentary evidence of title to kipat land provided the climate for further conversions of kipat into raiker tenure. Hit first the Government allowed that actual possession and the concurrence of local dignitaries would suffice for proof of omership in the absence of documentation. But in the 1888 edition of the Legal Code, and, indeed, in all subsequent legislation, failure to produce evidence

1. One muri is equivalent to $1369 \mathrm{sq}$. ft. It is also a volumetric measurement equal to 2.40 bushels. 2. See Chopter II. 
of tit]e was decreed tontamount to an admission that the kipat owner hod encroached on raikar land. In such an event the kipat land. would have to be converted to raikar tenure.

This led to further losses of kipat since, in most instances, documentary evidence was either totelly lacking or at best vague and open to conflicting inter.pretations. Although in some cases Subbas had received royal decrees stipulating the exact boundaries of their domains, in most cases, certainly in Ilom, the decrees merely confirmed that the subbas could go on using the lands of their forefathers. In one such decree given to the Kambo grentee in the Indreni Cluster, for example, it is merely stated that '..... you may use your ancestral property, whatever your forefathers used.....'

With such manner of evidence to title, it is obvious that kipat omers have always been vulnerable to accusations of encroachnent on raikor land.

In other ways, too, Government policies led to a retreat of kipet boundaries. Revenue settiements, postel services and army nointenance were partially financed by the surrender of kipat lands, but the subsequent reliance on altematives for roising such revenues did not result in the restoration of the kipat 
lands. Their conversion to raikar was judged to be irrevocable 1 .

Likewise, conceming the manner of expiation for offences of caste pollution, after surrendering 1000 muris of kipat land as raikar the Subbas of Limbuan were assured by the Government thet they coula deal with such offences themselves. Yet at the same time the Government imposed a tax for the very same purpose, and the courts ruled that the subbas hed no authority to expiate these offences. The lend, however, remained rajkar.

The courts and administrative offices in Limbuan apparently did little to redress the balance in favour of the kipat owners. On the contrary, they tended to find against Iimbus even when the law appeared to be on the side of the latter. When the owner of a plot of kipat land dies heirless his nearest co-heirs ore entitled to clain the land. This is the law. Even if the land has been given under usufructuary mortgage to a non-Iimbu creditor, the death of the kipat owner confers no special rights on the person holding the usuruct as against the co-heirs. Nevertheless, in

1. Report of Deva Man angdembe to the Shahi Commission, 1960. 
casos where the non-Iimbu creator sued for full ownership rights, the courts often found in his favour, and of course the land then became raikax?. In addition, the basis of the contractual system of taxcollection is that any homesteads built or lands brought under cultivation by the limbus need not be reportea to the authorities until a revenue settlement is held. But complaints of land or homestead concealment were continuously being entertained by the courts and govemnent offices between the holding of such settlements and the 'guilty' party would have his land confiscated and converted to raikar tenure ${ }^{2}$.

By the turn of the century the rote of kipat conversions into raikar had reached alarming proportions. Iimbus could not rely on land mortgages to meet growing demands for credit, since their non-Iimbu creditors insisted on outright purchase of Iimbu lands. The Government therefore executed a partial reversal of their policy and in 1901 banned the pernanent alienation of kipat lands to menbers of other castes. They decreed that henceforth no Iimbu could give his kipat

1. Report of the Nuluki office, 1947.

2. Ibid. 
by grant or sele to a non.-limbu. Two years later the decree was modified to jncluce under the ben only those kipat lanais under cultivation. But since by that time there was little wasteland the legislation had the effect of freezing the distribution of land in Iimbuan. Kipat lands ceased to cone under raiker tenure through contractual arrangements between Iimbus and members of other castes. Conversions did occur on a small scale, however, as a result of court decisions or by occasional Government directives aimed at specific areas of Iimbuan. Although the turn of the century savi the growth of an ever nore cautious kipat policy in Kathmandu, where the Government felt that it had little to fear from the limbus, anti-kipat measures continued to be bold.

Between 1912 - 1917 Ilam iistrict, where the Iimbus no longer formed a majority of the population, was the locus of a concerted effort on the part of Kathmandu virtually to abolish the kipat system ${ }^{1}$. The circumstances which gave rise tö this severe course concerned

1. Since Ilam was the most vulnerable part of Iimbuan due to its smaller proportion of Limbu population, Kathmandu would often test its kipat proposals there to geuge the reaction before applying theil in other kipat areas. 
the widespiead pledging of kipet lands. The restrictions of 1901 on pormenent alienation of kipat had intensified an already growing practice by Limbus of giving their kipat lands to creditors of other cestes under usufructuary or possessory mortgoges. The creditors assumed the rights of usufruct for a specified pexiod of time or, under other foms of agreement, until such time as the mortgage could be repaid. But the Iimbus continued to sink further into debt and $\theta$ s they did so, they were forced to ollow more and more land to come under mortgage. In circular fashion, as they lost access to their kipat, their chonces of earning enough to repay the mortgages and repossess their lands grew dimmer. iven those diminishing waste lands brought under cultivation by the Limbus had to be mortgaged almost as soon as they were reclaimed.

As a consequence, the Govemment in 1913 sought to ereeze the anount of kipat land in Ilam by ruling that any ner lands brought under cultivation by limbus between the revenue settlenents of 1890 and 1912 would be converted into raikar tenure. The rule was then amended to allow that $10 \%$ of these reclaimed lands 
could remain unaer kipat tenure and the amount in excess of that figure would become roikar. The Limbus, alarmed at the new proposels, suggested that the key to the whole problem lay in those types of mortgages which prevented the Iimbu debtor from re-possessing his kipat lands until the stipulated period of the mortgage had expired, even if the monies for repayment were available before that time. They then offered to refrain from mortgaging their lands, and take back those already pledged if the Government would alter the regulation on fired periods for mortgages and also agree to abandon its scheme to convert londs reclaimed between revenue settlements into raikar.

These somewhat bizarre negotiations reached a climax in 1917 when the Government introduced legislation ruling that the conditions offered by the Iimbus were to be accepted provided that they redeemed all kipat mortgages within six months. Failure to do so would result in the lands under mortgage and ony lands pledged in future being registered as raikar ${ }^{1}$. If

1. Order regarding Kipat Land in Ilam and Dasliajhia, 1917. Misis attempt to do bway with agriculturel indebtedness by threats assumed that the phenonenon was a Iimbu device to enbarross and annoy Kathmandu. In the same vein, Iord Hailey ceutioned Colonial governments concerning the problems they would call upon themselves if they allowed 'the nisuse by inexperienced peasants of the power of transfer or encumbrance of land.' (Iord Hailey, $1952,9.7$. 
the pattem in the Indreni settlenents was anything like typical of the situation in Ilam, it is unlikely that less than half of all kipat lands were under mortgage at the time. The enforcement of such a law would have virtually abolished the kipat system in Ilam. Although the order was promulgated in 1917 and re-stated as late as 1934, there was no attempt to enforce it in Ilam. Indreni informants suggest that local officials realized that if they had tried to enforce such regulations, there would likely have been widespread unrest in the district.

The underlying motives behind the Government's kipet policy, as I have already suggested, were mainly political. But fiscal considerations undoubtedly were of groat importance as well. By increasing the amount of lend under raikar tenure the Government could increase its income considerably. when the Government was contemplating the conversion into raikar of kipat lands brought into cultivation between the 1890 and 1932 revenue settlements, it was estimated that over Rs 60,000 would accrue in increased revenues. This figure represented over half the district's income from land taxes at the time.

The Government has more than once made explicit 
its concern that whatever noves it mekes in regard to kipat shoulc not result in any loss of revenues. When the Limbus suggested thet raikar land purchases by a Limbu should be convertiole into kipat tenure, the Government refused on the grounds of the decreased incorne from taxes which would result ${ }^{1}$. Again, as a prelude to the introduction of the 1917 legislation to turn kipot lands under mortgage into raikar the Government called on Ijimbus to offer their opinion and advice on Government proposals to a touring commission. The only caution was that whatever the limbus proposed 'should not result in any loss (or taxes) to the Government'.?

The need for funds to finance Government in the Limbu areas of the country was a constant problem. And taxation from kipat land contributed little to the general income. In Ilam, for exemple, although $39.7 \%$ of all paday lands in the district are under kipat tenure, tax revenues from kipat owners constitute only 10.6\% of the total land revenues. Mioceover, because of the peculiar characteristics of the taxation system

1. Report of the Huluki office, 1947.

2. Order to the Officers and Clerks of the Ilam Administration, 1913. 
as it applies to kipat, a decroase in the proportion of kipet lands bxings no comesponding decline in revenues from kipat owners.

Still, despite the obvious importance of fiscal coisiderations it is doubtful if they were of paramount importance in determining the Govermment's kipat policy. It would appear that the main concern of the administration all along has been the reduction of Iimbu hegemony in East Nepal and the control and decrease, not to say abolition, of kipat tenure was the first priority in effecting such a goal. Successive governments felt thenselves compelled to reverse those policies adopted by the early Gorkha kings granting Limbus a large measure of autonomy and security on their lands. The initial policy of support for the kipat system soon changed to one of encouraging a reduction of land under kipet tenure and a corresponding increase in raikar londs. But the process was gradual and choracterized by a series of seemingly petty encroachments often accompanied. by minor Government concessions to the Iimbus ${ }^{1}$. Generally specking, kipat was nibbled at, not swallowed whole. Jven the prohibition on the

1. Cf. M.C. Regmi, 1965, pp. 123-5. 
permanent alienation of kipat lond must be seen as an attempt to check the too rapid loss of kipat lands which had resulted from the Government's earlier course.

Kathmendu had to take into account Iimbuan's strategic location on the borders of Tibet, Sikkim and India. The Government's policy, therefore, while clear and consistent, was continually subject to the mitigating considerations of a volatile area which, because of its location and distance from Kathmandu, could prove difficult to control ${ }^{1}$. The authorities were aware that, in their own words, 'Far Kirat (i.e. Limbuan), a distant and extensive territory, rnust be governed through a conciliatory policy. ${ }^{2}$

1. In some perts of Jimbuan the Government has been unable to hold a revenue settlement since 1893 because of the intrensigence of the Limbu population.

2. Order to the Dhankuta District Court, 1880. Quoted in M.C. Regmi, 1965. 


\section{CHAITER IV}

THE HOUSSEHOLD

\section{Composition}

By a 'household' I mean a group of relatives shoring a common kitchen and budget. The same word ghar - is used to refer both to this group and to the dwelling it occupies. Although the tendency is for each household to occupy a separate dwelling not all, in ract, do so. In the Cluster there are two examples of more than one household sharing a common roof. In one instance, the widow and children of a Iimbu whose fother had settled uxorilocally in Chitok live on the verandah of their host's dwelling, which has been partitioned off to allow for privacy. In the other, two brothers, after separating from their father's household, reconverted an old house on the far side of the courtyard. Each lives with his spouse on a separate floor. A special door and staircase was built so that the occupants of the top floor could have direct access from the outside.

The great najority of Limbu households - 90.6\% con be classified as of 'simple' type. By this is meant that the core is on elementary or simple family. 
Such households may consist only of a core and include no other persous. Over half of all iimbu households axe of this latter kind (see Table 7). Others may include widowed mothers or unmarried brothers of household heads. Because of the stress on virilocality and patrilineal inheritance, households tend to be composed of agnatic kinsmen along with in-married women. Just over a tenth of Iimbu households, however, include other kinds of relatives as well. Table 6 notes their relationships to the household head and the reasons for their residence in the cluster.

\section{TABIE 6}

Attached members of Iimbu households

Relationship to

Numbers housebold head

a. 2 women Sister's doughters.

b. I boy ife's brother's son.

c. I women Sister's daughter.

a. 1 boy

e. 1 girl

f. I mar

g. 2 vomen

h. I woman

i. 1 boy iffe's son by previous marriage.

ife's doughter by previous marrjage. Bister's daughter's son. iife's sister and mother. Sister's son's daughter. Class. maternal grendson.
Reasons for residence

Raised from childhood. To attend school in. Bazar. jeparated from husband. Brought by mother.

Brought by mother.

Came for support. Came for support.

insther recently emisrated. Pather recently enigrated. 
In six of the nine cases above, the atta chment of affinal or matrilateral kinsmen is regarded as a temporary expedient until the persons involved join their husbonds (in the cases of women a. and e.) or their agnatic kinsmen outside the Cluster (cases b, $\mathrm{d}, \mathrm{h}$ and $\mathrm{i})$. By and large, economic difficulties rule out the permenent incorporation of non-agnatic kin. Table 7 lists six kinds of simple type household found in the Indreni settlements. 'Joint' type households are those which include a married couple or widower and at least one of their/his married sons and spouse ${ }^{1}$. As the Table shows, $9.4 \%$ of Limbu households containing $13.7 \%$ of the population fall into this latter category.

1. I have classified as 'joint type' two householas headed by widowers because in both ceses the seinior mele is still able to work ond to direct the activities of the sroup. 
Simple' type

Number Iation

a. Husband and wise and their chila(ren).

43

208

b. Iusband and wife and their child(ren), and husband's widowed mother.

4

22

c. Brothers, one married with child(ren), other(s) unmarried or without wife (wives) with them.

d. Brothers, one married with child(ren),

4

other(s) unmarried or without wife

(wives) with them, and brothers'

wiowed mother.

e. Hidow or widower and unmarried children.

9

28

f. Man or woman living alone.

4

4

8. Other kinds of simple type household.

\section{'Joint' type}

h. Husband and wife or widower and theirl his married son(s) and spouse(s).

Total households -

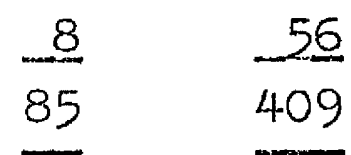

It is to be noted that simple type households contain an average of 4.5 persons while the number for joint households is seven persons. The Limbu household thus tends to be a small unit.

The low proportion of joint type housebolds anong the Iimbus might be compared with the proportion anong other castes. As Table 8 shows, of the six

1. See Meyer, 1960, p.180. 
Brohmin households in the Indreni Cluster, four are of joint type. Two contein narried brothers and their widowed mother, one a husband and wife and their two married sons and spouses, and another a husband and wife and one morried son and his wife.

TABLE 8

Non-Iimbu household composition

(Indreni Cluster)

Type ${ }^{1}$ Caste Number of households Population

a. Brahmin

Miagar

Blaclismith

b. Jaisi

Nagar

e. Blacksmith

g. Brahmin

h. Brahmin

Magar

Blacksmith

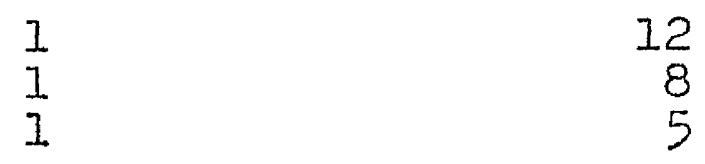

$\frac{1}{2}$

1

1

$\begin{array}{r}4 \\ 1 \\ 1 \\ \hline 15 \\ \hline\end{array}$
12

5

12

3

1.1

35

100

This tendency among Indreni Brohmins towards a. higher proportion of joint households is supported by figures from the Syawa Panchayat area. Of 153 Brahmin

1. Refer to Table 7 . 
households in other parts of the Village $17.6 \%$ are of joint type 1 . Juisi households, too, show a similar distribution of joint and simple types, with 19.3\% being of the former kind. Among the other caste groups only Chetri and Gurung households based on extended families exceed 10\% of the total. The latter, whose numbers in the Village are small, nevertheless control large landholdings, and the wealthiest Gurungs maintain large joint households.

There is, then, a correlation to be discerned between wealth and household type. As I will show in Chapter $V$, there are a number of non-Iimbu households, both within and in the immediate environs of the Indreni settlements on whom the Iimbus rely for a substantial portion of their credit. Of the fourteen most importent non-Limbu creditor households, nine are orgenized on the bosis of extended families ${ }^{2}$.

This correlation, however, appears to be bome out only partially when applied to the limbu joint

1. These household figures for the Village ore based on census data gathered by Ponchayat representatives. I accept their usefulness in inaicating trends or tendencies, but would not vouch for their complete accuracy.

2. See p. 176 . 
households in the Cluster. Weven of the ejght rank anong the wealthiest 30\% (23) of Limbu households. rost other households in this economic bracket, however, including severel of the wealthiest in the Cluster, are based on elenentary families, even though there are married sons who might hove remained under a single head. They chose not to do so.

The absence of this kind of correlation points up the need to distinguish between division of land and separation of hearth and budset.

Separation and Inheritance

Separation from the main household (mul ghar) is generally sequential, with the eldest son leaving first, followed by his younger brothers as they marry and bring wives to join them. It is not unusual for youngest sons, after marriage, to remain with their parents crwidowed mother once their elder brothers have separated. In the three cases of widlovs having more than one married son in the cluster these women Iive together with their youngest. At the time I conducted a census, there was not a single Iimbu household in the Indreni settlements containing two married brothers and their wives. This 
was true for joint households as vell. In each case where there was more then one married brother in a sibling group, the elder brother(s) did not reside with his/their parents or widower father and younger brother in a joint household.

There is evidence to suggest that the incidence of joint-type households was higher in former times. Some older informants state that in their youth younf men remained in their father's household unit their own chilaren approached the age of puberty. Several insist that in only rare instances would a son seek to separate from the main household before his father's death. It would appear certain that the partition of households occurred at a later stage of the developmental cycle since young men, who were married around the age of puberty, could not hope to establish new households until ther and their wives were sufficiently mature. This process would also correlate with the greater economic viebility of households before the turn of the century, and with the absence of alternative sources of incowe for the young men, so thet the older men wielded greater sanctions to leep the household group intact then is the case todey. Unfortunately, my data is insufficient to support these speculations 
in any concrete trashion.

The tendency towards early pertition is usually rationalized in teris of the strained relations anong the wives of brothers within a single household. One informant, two of whose sons had recently established thej.r own households described the process of separation in these words: 'men our eldest daughter-inlaw first came to the house seven years ago she was quiet and obedient. She did her work as her motherin-law told her to do. Then two years later the second son was married and the two daughters-in-law were brought together, They worked without troubling each other for a time. Then the younger one had a child, and she had to stay home and take care of it. So she did less work, but she needed the best food. st first the eldest daughter-in-law understood, but soon she complained to her husband that she worked too much, and that her sister-in-lew did nothing. When another child was born to the younger one, the dauphters-in-law quarrelled often, and then even their husbands begen to have bad feelings. The eldest son repeated the words of his wife that the jounger brothex's femily was getting more to eat even though they contributed less to the household. So last year they 
both said they wanted to build separate kitchens (chulo) and we dia this. It is better now, they do not fight anymore.'

This description traces the growth of separate nuclear units within the larger group, and the strains between these units which lead to the partition of the household.

flthough household partitions are most frequently attributed to disputing daughters-in-lew, another, not uncommon, explanation is the tension arising out of the co-residence of wives and merried sisters. The latter, since they are not co-perceners in the household's lands, are not structuraliy opposed to their nale siblings. Moreover, since they go to live in their husbonds' settlements shortly after marriage, they do not represent a threat to the status of their brothers' wives. However, when women leave their husbands and retum to reside, sometimes permenently, in their natal hones - a not infrequent practice - condjtions are created which can lead to strains between sisters and biothers' wives and, ultimately, to the break-up of a household. Daughters are indulged to o much greater extent by their parents than are the latters' daughtersin-law. It is comonly adnitted that a woman, however 
kindly she mey be disposed to her son's wife, will invariably favour her ow daughter in ony intrahousehold squabile. Arguments often arise when married daughters living in thein natal households are allowed the customary privilege of earning a private incoine over which their fathers can exercise no claim. As will be explained below, although in-married wives also hove certain rights to possess property outsice the househola estate, it is not until thejt are mistresses of their om households that they can fully exploit their rights. As long as their activities continue to be controlled by their motherin-lav, little time is avoilable for personal business. As a result, daughters-in-lay see themselves as contributing their time onc energies for the benefit of all household members, while their husbands' sisters are free to spend much of their time accumuloting a private equity, and thereby neglecting obligetions to the household unit. In sucin circumstances, the pressures for partition are strong. It was generally acknovledsed, for example, that when the only son of a Bhorapa mon established e separate household in the spring of 1964, the detemining factor was the constant quarrelling between the young man's wife and his two 
married sisters who were living in their natal household.

Finally, in addition to the disputes among brothers' wives and between the latter and their husbands' sisters, the strains inherent in motherin-law - daughtor-in-law relations also contribute to household partitions. Indeed, the belief in the inevitability of hostility among the women of a single household occasionally leads the parents of a recently married girl to refuse to allow her to join her husbend until arrangernents have been completed for the establishment of a separate household by the young couple. The creation of a new household usually, but not invariably, implies its independence as a landowning unit. The rules of inheritence practised by the Iimbus resernble those prescribed by the Mitakshara system found in north India. Under this system, a household estate is conceived es being shared equally by a man and his descendants - in the case of the Iimbus his male descendants - and each male offspring secures his rights at the time of birth ${ }^{1}$.

1. Vijnaneshwar, who expounded the ritakshora system, spoke of the principle of ownership by birth'. 'This is the opposite of the Deyabhaga principle whereby rights are acquired by the sons only on the death of thejr father. Thus, 'the principle of ownership by death'. Cf. Karve, $1965, \mathrm{p} .344$. 
In effect, this means thet $\varepsilon$ nan's sons cen claim their share of the property at ony time, elthough in practice such claims are pressed only arter merriage 1 . When the partition of a household is accompenied by a final property settlement, the son who sets up a separate household renounces any claims on property accumulated at a later stage by his father's household. His rightful inheritance may be augrented after the death of his porents by a portion of the property (jiuni) which a father puts asioje for himself and his wife to sustain them in old age. A father can determine who is to inherit this property arter his death and that of his wife $e^{2}$. Generelly, it is decided to share it out equally axongst the sons, but if the youngest soin lives with and helps to support his parents in their old age, he may get the entire jiuni after their death. The exercise of inheritence rights by Indreni Limbus occasionally proceeds by stages, so that the separation of a son from the main household may not

1. ficcording to Karve, under the Mitakshars rules 'the proper time for the division of property was any time the co-sharers in the property wished. to effect a partition. ' Ibicd, p. 345 .

2. Claims to jiuni constitute a frequent canse of quarrels eriong brothers. See for exomple, pp. 32?-28. 
coincide with a final division of property. He might toke only a temporaxy settlement pending the marriage of his younger brothers. Frequently, only sons establish households away from their parents. The heads of four households in the Indreni settlements are only surviving sons whose parents are still alive. In such cases the son takes only that amount of property necessary to provide an adequate living, since the entire inheritance will, in time, come to him.

Occasionally, the partition of a household results in the division of only certain kinds and limited amounts of property, with the rest left undivided and under the supervision of the head of the main household. This arrangenent satisfies the desire of a young couple for a separate householä and yet the unit remains only partially independent in terns of property. In this, as in all stages of the process of division, the kitchen and budget of the new household are quite separate from the rain household. HIl income remains the property of the household and its expenses and debts are its own responsibility. Nevertheless, in the eerly stages of separation, especially where certein types of property (such as cattle, for exanle), are left undivided, the amount of cooperation between the 
main and the new household can be extengive. The two households maintain a continuous interdependence and an interest in each other's affairs not usually found between households where the division of property is more complete. Indeed, in many respects they continue to act as a single unit. In the Indreni Cluster this kind of relationship tends to exist between the agnatically related households of the few wealthiest Iimbus. In other words, the wealthier bouseholds can be seen to prolong the division of property more so than the less affluent limbu households. In the case of the latter, the household head can apply no sanctions to forestall the early division of the group's estate, so that household separations usually coincide with the division of household property.

But the sons of wealthy men are reluctant to force a division of what may be an expanding estate. In questions of inheritance, no rigid distinction is made between ancestrol and self-acquired property, since a household head is not expected to maintain a private estate separate from that of the household. This is especially true of wealth which bas been converted into land. Ihus, for example, when the sons of a Chitok men who enjoyed a regular cash income 
from non-agriculturel sources received e partial settlement upon a partition of the main household, each son was given land which had been pledged to their father ggainst loans made with the latter's cash income. As long as the income remains in the form of Iiquid assets, however, the sons could not demand a share during their father's lifetime. By holding out the prospect of a larger inheritance in the future, a nail can hope to delay the final division of his property despite the partition of his household. The term 'separate' housebold thus disguises the various kinds of relationship which can exist between a new household and the main unit. When this is recognized we note that the ties among some - usually the vealthiest - households liken them to a joint type housenold. In this regard, the correlation between wealth and type of household tends to follow the pattern found among Brahmin and other caste groups. Stated differently, the werlthiest Limbu housenolas in the Cluster are either of joint type or cooperate as if they were?

1. In this regard it is worthwhile noting a remark by Freedmen: '...Co-operation betireen closely related households of a kind to make then seem to resemble one houschold was nore likely to occur anong the better-off.' (ireedinan, 1958, p.30). 
Although, as pointed out, a division of the estate can be arranged on a variety of bases within the household, a finel property settlement, to be valid. in the eyes of the comminity (and the law) must be effected in the presence of several respected elders. Such settlements generally occur after all the sons of a man have married and established separate households, and occasionally it is delayed until after theis father's death. Ht this tine, a written document is usually prepared, setting out the terms of the agreement, and it is then signed and witnessed by the elders. Fiftyeight of the 85 Iimbu households in the cluster have made what can be regarded as a final property settlement, and 37 of these have prepared docunents attesting to the agreenent, while the rest have relied on verbel settlements, backed up by customary knowledge of boundaries. Many in the latter category suggest that a written agreement will someday be mede.

But even a final settlenent may leave sone lands undivided so that nore than one housebold head would have a stake in the same fields. The inclusion of tracts of undivided property in a settlement is a function of the heavy mortgaging of kipat lands to obtain credit. Irends to which the Iimbu owners have long lost 
usufructuary rights are passed on from fathers to sons, sonetimes with only cursory attemts to define the boundaries of each parcel. Thus, it is not entirely uncomion to find sons of one father sharing some undivided lands, and descendants of a common grandfather sharing others. These questions are usually clarified at the time of a revenue settlement when households and their irrigated fields are registered, and the boundaries of the latter defined.

The definition of the household group is also influenced by the system of tax collection on kipat land. As mentioned earjier, the contractual system of tax-collection prevalent in limbuan requires that kipat owners pay taxes according to the number of households and not in relation to the amount of land omed or cultivated. But households are counted and registered only at the time of a revenue settlement, and no amount of increase or decrease in the number of households between settlements need be reported. The last revenue settlement in Ilan in 1936 registered thirtymine households in the Indreni sett]ements. Todey there are 75 kipat-owning household units. The taxes essessed on a registered househola are shared amongst those households which separate off and divide the lands 
of the former after the revenue settiement. Ihus, in the case of Chongbung Lineage (5), twelve households share the tax burden on six registered households in the nanner indicated in Figure 4.

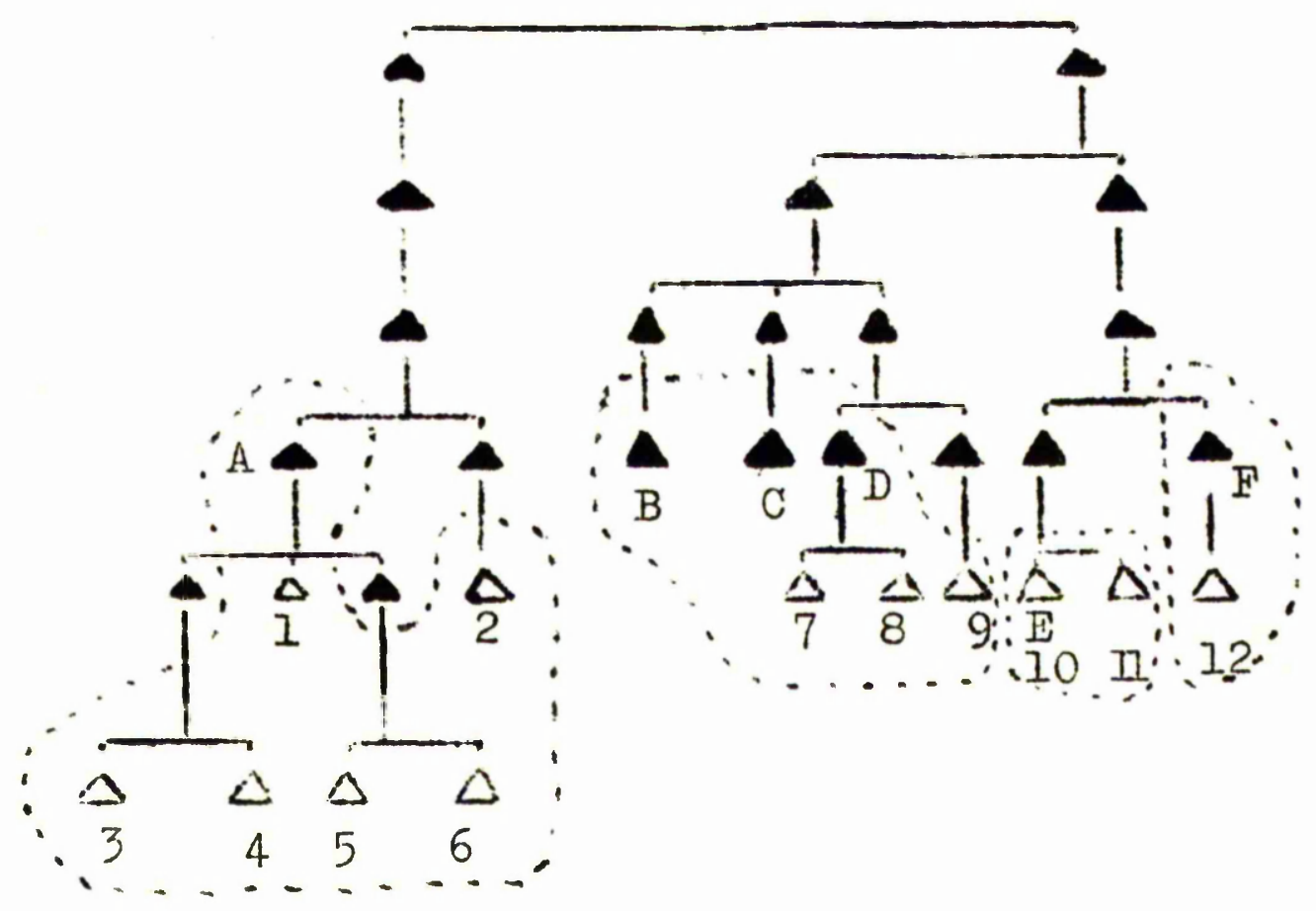

Registerea households are lettered Existing households are numbered

Fig. 4 .

The tax burden on Chongbung Lineage (5)

households are distributed as follows: households I - 6 share the tax on s; households 7 - 9 share the tax on $B, C$, and $D$; households 10 - 11 share the tax on $E$; household 12 pajs the tax on F. Within each 
section the distribution is not necesserily equal as between households of different generations. Thus, for example, the tax on $i$ would be distributed in the following manner: household 2 : $\frac{1}{2}$; household 1 : 1/6; households 3 and 4: $1 / 12$ each; households 5 and 6 : 1/12 each. And so on.

Alternatively, where the existing households now outnumber the registered units, the tax burden on the former is proportionately greater. In the case of one Kambo lineage, for instance, the household population has decreased due to a number of household heads dying heirless. As a result, two existing households must pay the tares assessed on five households registered at the time of the last revenue settlement.

It would seem that traditionally the method of taxing kipat-owning households might have put a brake on the partition of households. Because all housebolds registered ot the time of a revenue settlement would have been taxed without regard for the size of the estate, a conflict arose between the desire to establish an independent housebold and the realization that such a step would mean a heavy tax burden for the household. Since the turn of the century, however, 
with the drop in the value of the rupee", taxes no Ionger represent a sicinificant expenditure ${ }^{2}$ and so this is no longer a serious consideration in the calculations of potential householders. Even so, I have been told that at the time of a revenue settlement some householas 'merge' together in order to avoid being registered ${ }^{3}$.

The system of kipat taxation also serves to stress the links among closely related households within the same agnatic lineage or lineage branch. Despite the tendency towards early partition and the fragmentation of estates, the very persons who are the protagonists in such divisions are potential heirs of one another's property. The eclipse of a household whether through emigration or the absence of male heirs results in the transmission of its tax assessment to the nearest agnatically related household, which also assumes ownership rights in the former's estate.

1. Since 1914, the price of paddy has risen approximately fourteen-fold in Ilam.

2. See p. 224 .

3. During $\&$ Penchayat-instigated household count in 1963, the census-taker, a Brahmin, was astonished when he was told that the only Iimbu households in the Cluster were those registered by the revenue settlement of 1936. 
In Figure 4 the heads of households $B$ and $C$ died without sons to inherit their property ond oblicrations, which then passed to the nearest collateral. line, represented in the Cluster by the patrilineal descendants of their father's brother.

\section{Women's Rights in Land}

The foregoing discussion of property division has suggested not only a stress among Limbus on the patrilineal transmission of land but on the exclusive inheritance rights of males. Even the word 'aputali', which indicates one who is childless, is used to refer to a men who has daughters but no sons and implies that he is without heirs. What rights, we might ask, do women have in kipat lands?

On marriage, a women forfeits all rights to the lands of her natal household. As I suggested in Chapter II, when land was in greater supply uxorilocal residence was a not infrequent practice. Until about fifty years ago daughters or sisters whose husbands settled in the cluster were occasionally given small plots of land as pert of their dowry, which lands were then inherited by their sons. But these grants were never regarded as a customary or legal right of lineage 
women to a share of the patrinony. When a married woman or widow resides in her natal household she expects to receive support, but can exercise no claims to land. In the case of an elderly woman who returned to the Cluster after the death of her husband and chose to live alone in a soparate household, she was allowed to live on and cultivate a small plot belonging to a syeling man, although she was a Chongbung. Her lineage agnates were under no obligation to provide her with land.

Unmarried daughters, however, on reaching the age of thjrty-five, have a claim to a share in the estate, equal to one-half the inheritance of each male sibling. In the event of the woman being an only child she assumes rights in the entire estate following the death of her father. These rights, however, are hedged by three main stipulations. In the first place, a daughter can only press her clains if she establishes a separate household. $\quad t+5$ Iong as she resides with her iather or brother her status is similar to that of an unmarried brother, and her shore renains in the custody of the household head. Spinster daughters, in fact, seldom urge their prerogatives since the difficulties of managing a houseluold onc an estete alone are 
considered fomidable. Desiaes, property divisions among sons take no account of the possibility that a female sibling might renain unmarried. By the time a woman reaches the ace of thirty-five the estate has usually been allocated taher brothers and she could, only with the greatest difficulty, obtein her rightful share. I have heara of no cases of such a redistribution to accomnodate an unmerried sister actually taking place. In the Indreni settlements there were three spinsters in this age bracket and one, an only child, inherited rights to the lands of her father, from which she maintained a separate household. The other two were residing with their brothers.

A second condition concerns rights of transmission. The land cannot be gifted or in any way trenswitted permanently to anyone other than the male agnatic heirs . Then the spinster mentioned above died in the early part of 1955 her movming rites were performed by three agnates of the nearest collateral line who were to divide her lands. A young married

1. Before 1901, when kipat was olienable by sole, a spinster daughter could not sell the lands. arly, if land is reikar it cannot be sold by unmarried wornen. 
woman, who vas the dead person's sister's dathhter, and who had been living in the sewe household, was regarded as having no claims whatsoever to the spinster's lands.

itven to pledge lands to a third party, an unmarried women must have the permission of the potential male heirs. Her rights, by and large, are restricted to the use of the land during the course of her lifetime provided - and here o third condition applies -. she remains unnarried. On maxriage her rights would be forfeited.

In some respects, the ribhts of a wife to lana are similar to those of an unmarried daughter. While she remains part of her husband's housenold she is entitled to support, but camnot demand a separate share of the estate. Nor can she choose to establish a separete household without her husband's permission. If a man takes a second wife, however, the first then hos the right to claim half his estate ond to estoblish a household for herself and her children, if she has any. There is some disagreenent about the pattern of inheritance following on such a division. some informonts maintain that land would be divided equally among all a man's sons, while others suggest that the 
sons of each vife would inherit only that portion of the estate held by their mother. Although the two contradictory ideals exjst aide by side what in fact appears to happen when a man has sons by more than one wife is that the wife who establishes a separate household is aljocated an amount of property according to the number of her male heirs. In one instance I was able to record, the four sons of a mon by his first wife each inherited an amount of property equal to that given a ifth son born to his second wife.

The existence of contrary notions about inheritance is partly a reflection of the lack of precedents in such matters due to the low incidence of polygynous unions ${ }^{1}$. lien seldom marry for the second time while their first wife is still alive unless she has produced no sons, goes away with another man, or returns to live in her

1. I was surprised to learn that the $1 \mathrm{ack}$ of clarity about the rights or half-brothers did not lead to a spate of quarrels. In addition to the dearth of polygynous unions, it is probably due also to the fact that most kipat lands have been pledged away (see Chapter $V$ ) so that helf-brothers would have only titles to quarrel about, unless of course the household was rich and had managed to retain full use of its lands. In one dispute, hovever, the descendants of an only son by e first wife did claim half the lands of her husbend. See pp. 75 fr. 
natal home because of fulluxe to get along with her husband or other members of the household. Only eight Indreni men have two wives. In four cases a second wife was merried because the first was barren; in one case because she had borne only daughters; in another case an only son had died after his mother was beyond the age of child-bearing; and in two cases because the first wives, neither of whom had hed any children, returned to thejr natal homes shortly after marriage and had no intention of returning to their husbands.

Certainly, an important reason inhibiting multiple marriages relates to their high costs ${ }^{1}$. On the other hand, prestige does not attach to a man with more than one wife, and the wealthiest Limbus in the Cluster are monogamous. Indeed, a man with two wives is often regaxded with a mirture of pathos and amusement. Wile co-wives remain together (two Indreni households contain both wires) quarrels are considered inevitable, and a husband who must wollify his spouses is little envied. The quarrels almo to invariably lead to seperation, with one of the women, usually the senior 
wire, either leaving the juster and retuming to her natal home - as dic the wives of two men - or moving into a separate homestead within the Cluster and becoming custodian of part of her husband's estate. Such a division has been effected in two cases where first wives have novea away from their husbands ${ }^{1}$. When a wife clains her rights to a part of her husband's lands, she becomes, in effect, the head of a separate household. whe controls the income and expenditure of the unit, and directs the labour of its members. Although her husbanc continues to enjoy sexual rights, he does not cominand her labour or that of ber household, and cen assert no clains to its incone. But he does retain a veto over the trensmission of his lands by his wife to third parties. Fe also continues to take a strong interest in the affairs of her household, and a husbond would be consicered remiss in his duties if be did not txy to help in every way he could. The husiond of one woman who had established a separate household with her daughters arranged a lucrative tenancy agreenent for his wife and agreed to act os guarantor of the rent.

1. There have been instances of a husband continuing to reside with his first wite and alloting a seperate homesteed and estate to his junior wise but this happens rajely. 
Some informents suggest that the division of a man's estate does not merely confer rights to a portion of his lands on the wife who separates, but leaves the renainder of the estate under the control of the other wife. Thus, it is said that 'when a men has two wives he has nothing'. The husband in such a situation is viewed as a pouper dependent on the goodwill of his spouses for his subsistence, and discussions of polygyny often include a joke about ' the inan who starved to death between the homesteads of his two wives'. In fact, a husband resides permenently with one of his wives, and is the effective household head, in control of its estate and in complete chorge of its personnel. The point has been stressed thet the right to establish a separate household accrues to a wonan only if her husband takes another wife. But it is also contingent upon her continued residence in the cluster. If a woman resides in her natal household she forfeits her claim and if she leaves after hoving already established a separate unit, her husband re-assumes control of her portion of the estate. The fact thet this usage is sanctioned by both custom and law, howeves, did not prevent one wife living in her natal home from pressing successfully - Por half her husband's lands. The case 
is worthwile recounting because it presents a good example of norns being enunciated ond clarified at the very tine they are being disregarded.

In 1953, a wealthy anc much respected ex-arny serviceman of Chitol. arranged the marriage of his eldest son to the daughter of 8 man of similar status resident in a settlement cluster about fifteen miles west of the Indreni settlements. About a year later the young wonen came to live in the Cluster, but uneble to get along with her husband, returned to hex natal home after a few months. Her husbend nade no attempt to persuade her to return, and in 1958 he merried for the second time. In 1963, he established a separate household and received a partial properity settlenent. In Jonuery, 1965, the first wire, hor mother, father's brother - her father had since died - and sevoral other kinsmen come to Chitok to demend a divorce. They accused the young man's fether of allowing his son to menry another wife without first using every possible means of persuasion to have the first wife rejoin her husband. The boy's father and his supporters (with the latter carrying the burden of the discussions) reminded the girl's family that it was not contrary to limbu custom for a nan to teke a second wife, but that they still regarded the 
girl as their doughter-in-law. As such, she had every right to claim the presogatives of a wife and denand a half-share of her husband's estate. The girl's representatives were ademont in their demands for $a$ divorce, but the young men's side were equally fim in their refusel to grant one. Although the reasons were never made explicjt, it was clear to everyone that to acquiesce in a divorce would mean waiving their rights to recover at least a portion of the maxriage expenses if and when the girl re-married. After about two days of conversations, the girl's family agreed to accept the offer of half the husband's estate, but on condition that the women would continue to live in her natal home. This shocked the Indreni men (and the many women who had gathered to enjoy the spectacle; even more than the demand for a divorce. In the enc, hovever, after protesting that such an arrangement was contrary to alI custon, the young man, witi the support ot his isther, agreed to the condition of theij in-laws. An agreement was reached whereby tie husband voula cultivete those lands over wich his first wife now had usufruct, and Day her a fired amount as rent.

Privately, the boy's fatber and otier observers rationalised the decision by surmisine that the jol's 
family had really come to 'reise their prostige' and that sooner or later the young women would marry onother mon, whereupon hew Indieni husbend would receive compensation and at the sane time resume full rights in his Iends agein.

Finally, the rights to land of wi.dows wj.thout sons should be mentioned. Following the death of a mon who leaves no male liairs his property is inherited by his nearest agnatic kinsmen. Their claims, however, are held in abeyance during the lifetine of his midow. Like spinster daughters and wives who have separated the widow enjoys rights to the usufruct of the land, but cannot alienate or pledge it without the expressed pernission of her husband's potential heirs.

Thus, we have seen that certain women heve well defined rights to land and its products during their lifetime, subject to speciric restrictions on their freedom to dispose of these rights. The categories for which these prerogatives are prescribed include women who for a limited phase of their lives ere faced with a loss of economic support from their husbends or fothers and brothers. The rights granted these women thereby enable them to achieve a measure of security when it is most needed, yet neintains the patrilineel 
pattern of land ownersipip and inheritence proctised by the Limbus.

Relations within the Household

As noted at the beginning of this chapter, the Iimbu household tends to be a small unit based on a simple family. In effect, this means that relations within the household are synonymous with those between members of on elementary family.

I may have given the impression earlier that the Limbu household is a scene of continuous squabbling as younger members press theix clains to independence. In foct, these stresses emerge gradually and undromatically, and characterize a particular phase in the developmental cycle of the group. For the greater port of its lifetime, relations within the household are anicable and co-operative. To govern these relations a body of traditional rules offer guidelines for behaviour. I. father's attitudes towards his male offspring cannot be sumed up by a single term. They can be seen to change through time as a son proceeds through the various stggas of the rifo cycle. I ban without sons is much pitied. 'is mon must have a son to inherit bis property and nourn him when he dies' is how the 
Limbus invariably explain the desire for nale chiloren. The remorks of one limbu following the birth of his first son after twelve years of marriage had given him only daughters illustrate the depth of a man's feelings about mele offspring. 'The birds were sleeping previously. Wow they are awakened. They are chirping and flying to and fro. Ell living beings are owolrened. Now the sun is risen. All the rivers, streains ano fish are awakened. Trees and hills are swakened. All ane awakened now.'

The early years of a child's life are free of any responsibilities. He is regarded as an infant (balak) and indulged by his parents and other members of the cormunity. At this stage, he is an object of affection and fathers are frequently to be seen walking or visiting others with their young sons in their arms or on their shoulders. There is no shame attached to such display of fondness for a small boy.

A gradual change in the character of a father-son relationship occurs when the child is reckoned old enough - around six or seven years of age - to assist in various tasks outside the homestead. Then the boy begins tending cattle and helping in the fields his father assumes the role of instructor and disciplinarian. 
The affection and familienity of the early years dissolve as the relationship becomes more formal.

When asked to state the ways in which a youth should behave towards his father Iimbus usualiy refer to the dominant pattern evident amongst their Brahmin neighbours. They suggest that a son must be reticent in the presence of his father, must not share the same bench or sit on a level above the latter, nust speak guietly and with respect, and never interrupt or contradict his father. In proctice, however, Iimbu behaviour falls short of these ideols. Certainly, ofother is treated with deference and it would be a rare Iimbu son who joked with or behoved towards the formen with disrespect. But aiter heeding the degree of rostroint in a Brahmin household, the observer cannot help but remark on the coinparative lack of inhibition which characterizes the eather-son tie in a Iimbu family. Iimbu sons, for example, smoke freely in the presence of their fathers, join in their conversations with others, express opinions without hesitation and behave in ways which no Brahmin father would countenence from his sons. This permissiveness does not alter the superordinate-suborainete principle underlying the father-son relationship among the limbus, but mitigates 
considerably its implications for bebavior.

although puberty is not marked in any formal

way, it is recognized as the phase during which membership of the community is attained in the sense that full mourring rites would be performed by members of \& youth's household and Iineage in the event of his death ${ }^{1}$. Irormerly, a pubescent boy was thought to be near reaciy for marriage, but nowadays little thought is given to finding a wife before the age of seventeen or eighteen. Even so, new sezual awareness and a growing sense of independence encourages a youth to spend a good deal of his spare time away from his parents, usually in the compeny of age mates of the same sex. Often, they do not sleep in thein own dwellings, but circulate amongst those homesteads in which there are no males of the next ascending i.e. their father's generation.

t.S a boy epproaches the age of marriage, tensions between he and his father increase. He senses his growing importance in the economic activities of the

1. Some informants state thet these rites are often performed after a boy cuis his second teeth, but that et this stage it would not be obligatory to do so. 
household. sis his father grcis older, heevy agri-culturel tesks are increasingly assigned to the young man and he regards himself as the meinstay of the unit. He is also able to earn a cash incone from agricultural labour and a variety of other sources both within and to an extent outsice the region oi the Indrenj settrements. But as long as be is part of uis father's household, his laboln is at the comend of the latter. And whatever cosh income he eams by his own efforts must be chennelled into the househola budget over which his father retains conplete control'. jome voung men find the situation intolerable end run away from home, usually to a town in vest Ben where they attenpt to find work. Occasionaly they try to join the army. While $I$ was in the Indreni Cluster four young men left home without informing their parents where they were going; a.l four returned within eight months. When they were asked their reasons, each inaicated a desire to 'see the world', but two tien pointed out thet 'bere we work and in the end have nothing'. The fact that they almost always do return, however, reveals the

1. There are certein exceptions to this rule in the cose of the salaries of young men serving in the army. See chapter VI. 
other side of the young men's dilemna. For, despite the strains in the selationship with his father, there is the realization that he is depencent on the latter not only for day-to-doy support, but for the means to enable these tensions to be resolved. In other words, he is beholden to his father for the monies to malre a marriage, which first step must be taken beiore a separate household can be established and a division of property effected. Since the costs of marriages are borne entirely by the housebold, it is only by fulfilling his obligations to this unit - which include the acceptance of a father's authority - that he con hope in time to win his rights.

Until they marry and become full co-parceners in the patrimony, brothers live amicably within the household1. As children, they play together and except for the fact that the eldest is usually made responsible for the safety of bis younger siblings, no special importance atteches to age diffecences. Hs they grow

1. It is sometimes aad that the eldest son belongs to his father, anc the youngest to his mother, but few parents would admit to having favourites. 
older, however, each develops iriendships with others in his ow age bracket, so that the intimacy of the early years gradually diminishes. Although ideally an elder brother is his younger's master, in practice the relationship is marked by a lack of obsequiousness on the part of the latter. If a father should die before his sons have all seporated, the eldest son living in the household succeeds to his father's position and authority as household head, provided he is married and provided his mother is advanced in years. In such circumstances the importance of seniority is stressed, and an elder brother dominates the affairs of the household and controls the same sanctions as did his father.

Throughout this anolysis the patrilineal bias of Iimbu descent, succession and inheritance has been stressed. It is obvious that the sons of a narriage are incorporated fully into their father's lineage. The stetus of a caughter, however, is less clear. Until her marriage she too is considered a member of on agnatic group which exercises full control over her person. Are these rights, we might ask, ever surrendered? What claims over a women are retained by ner agnates ofter she is married, and how do they compare with the 
prerogatives of her husband's group?

* husbend has undisputed sexuel rights in his wife, and if these rights are violated, he is entitled to compensation, which transaction signifies the dissolution of the merriage1. But a man's death leaves his widow free to remarry. If she chooses to do so, the bridewealth and other marriage payments demanded of the new husband are given not to her late husband's agnates, but to her natal kinsmen ${ }^{2}$. IA widow is a virgin (kenya), explain her agnates, and bridewealth must be paid anew for sexual access. When the widow of a Chongbung decided to leave the Cluster in 1965 to morry another man, the father of her late husband made no attempt to dissuade her since, on her husband's death, his group retained rights only to her children - although it still had the obliggtion to support the widow while she remained in the loonsohold. In this sense then, marriage can be seen to confer on the husbend rights to the reproductive powers of his wife, but does not transfer to

1. See Chapter VII, pp. 313 ff.

2. 'A test of the married woman's absorption into her husband's group was her fate on widowhood.... when .... she chose to get or was given another husband the rights over her in second marriage lay lorgely with her first husband's people.' Cf. Freedmen, 1958, p. 31. 
him or his agnates complete ard permenent rights to her person 1 .

A woman's attachment to her agnatic group is also symbolised in the custom of putting aside a token quantity of the production of each paddy field for the daughters and sisters of a household, including those who have married out. This custom is said to please the deities controlling rainfall and to assure an abundant monsoon in future.

The obligation to perform the mortuary rights for a woman resides with her own agnatic kin unless and until a special payment -. called 'saimondri' is made by her husband or sons to her natal household. This payrent transfers the mourning obligations from the woman's lineage to her husband's group. I have heard it said that a woman is not a wife until saimondri is given ${ }^{2}$. The aecision about when to pay

1. Leach spealis of procreative rights to o Lakher woman being 'rented' by her husband. (1961a, p.119).

2. The traditional implications of suimonari might very well hove been significant. one of the Jimbu texts (undated) in the Iodgson Collection at the India Office Iibrary states that the children of a divorced Iimbu couple would be 'illegitimate' if the fee were not poid. A Limbu informant in the Cluster suggested that formerly foilure to pay soimonari would give a women's agnetic kin the right to claim the chilaren of her manxiage. 
the fee rests with the husband, end it connot be refused by the woman's agnates. But it is almost never offered until the women has had chilaren or until she receives a dowry, and the belief exists that if it is given too soon after marriage it will hasten a wife's death. Occasionally, sojmondri is delayed until after a woman has died. If this is done her agnates are not bound to accept the offer, although in practice they seldom refuse. Thus, for example, when the wife of a Kambo man died her parents, who had come to visit during the final stages of her illness, agreed to accept gaimondri which had not previously been paid and arrangements were quickly concluded for the amount to be handed over by the dead. woman's husband.

Failure on the part of a husband to pay saimondri - which is only a nominal amount - leaves with the woman's natal group not only the obligation to perform the mourning rituals, but the right to reclaim her personal possessions. These are of two kinds: her dowry and other self-acquired property (pewa). Some years following the marriage of a woman her lineage must provide a dowry. The obligation folls most heavily on her natal household which 
furnishes the majoz share - usually jewellery, or money or, less frecruentyy, cattle - wile lineage members who received a part of the marriage payments contribute a variety of household utensils. With her dowry as initial capital, she wight then make interest-bearing loens or earn other income from petty trade. Generally, the women who engage nost actively in earning a private izcome are married or elderly spinster daughters living in their natal householas. wives, on the other hand, spend most of their time working around the homestead or in the fields, and so have little opportunity to pursue private interests. Besides, a woman who neglected her household obligations to increase her personal property would be upbraided by her husband and much maligned by other members of the community. Nevertheless, over the Jeers, many wives manage to accumulate some private property in adition to their dowry, and a husband has no legitimate rights to this wealth. A woman often allocates some of her belongings - in particular jevellery - to her deughters and less often, distributes cash on cettle to her soms. After her death, however, that portion which nas not been allocated can 
be clajmed by her netal kin - unless sainonini has been peid ${ }^{1}$.

In sum, then, what energes from the foregoing outline of differential rights to wonen enjoyed by agnatic and affinal households is a picture of a weak manriage bond and, altematively, of an enduring link betiveen woman end her natal group. Such a structural representation, however, must be balanced by a description of the affective aspects of the marriage relationship.

Relations between a husband and wife, like those between a fother and son, undergo changes over time. Following the wedding, the new bride spends several weeks in her new household - et tbjs juncture this woulc mean the household of her father-in-law during which time she is introduced to her duties and begins to know the nembers of the group. The young couple would scarcely speak to one another out of shyness, and it is unlikely that they will have sexual

1. Consequently, some limbus reigh tre costs of funerary rites, which are quite high, against the value of the possessions their wives have accumulated before deciding whether or not to pay saimoidri. 
relotions. At the end of this brief period the pirl returns to her natal household vhere she remains for about one yeer, although the husband would visit her on one or two occasions during this time ${ }^{1}$. When she retums to live with her husband, the nelationshjp is still tentative, and depends for its success on a number of factors. I have already suggested that ties between a wife and her husband's mother and brothers' wives can lead to strains and disputes. But the marriage tie itself can be affected by the attitude of a husband in these matters. A husband has always to balance the obligations towards his parents against his interests in the nuolear family in which his wife will play an essential role. Several Indreni women have cetumed to their natal homes in the Cluster because their husbands would not support them against their mothers- and/or sisters-in-low. thter a wife becomes mistress of her own household the ties with her busband become less fragile, but a man who is inconsiderate to his vife risks ariving

1. This is true only for arrenged and 'theft' merriages. when a man abducts onothen's vife, the latter would not return to her natal housebold after the wedaing rite. Jior a dotailed account of morriage, see Chepter VI, pp. $238 \mathrm{fP}$. 
her back to her natal household. vomen not infrequently take refuge in their natal homes, where they are always welcome, and if her husband is the cause of her flight, he will hove to face en angry group of affines when he comes to fetch her back. If the pattem is recurrent, a women may be persuaded to remain permanently in the household of her birth, and even be encouraged to run away with another man.

The birth of a child, particuloriy if it is a boy, gives the wife new status, and puts the conjugal relationship on a firmer basis, thus increasing its chances of persevering.

* woman is said to regard her husband as her master, and to clothe her every attitude towards him in respect. illthough a wife's behavior in public would not belie this ideol, the situation inside the household con be quite different. Some men are known to be 'henpecked' and snide anecdotes occasionally circulate to point out the victins. But in the majority of instances, a busband is rocognized as the authority figure, and a wonan will seldom dispute her husband's decisions. Even so, a wire exercises a strong influence on these decisions by virtue of her relationship with the children. At woman's role 
includes the instruction ond disciplining of her daughters, but she is also their closest confidante before they marry, and few ties are considered as close as that between a mother and daughter. But mothers feel no less affection for their sons. Eince a boy seldon discusses matters of a personal nature directly with his father, he will reveal his feelings, address complaints or make requests through his mother, who is then counted on to intercede on his behalf to her husband. Thus, a wife and mother is the dominent object and source of affection, and this enables her to exercise a not inconsiderable influence on household decisions.

By the time a married couple approaches middle age, and the vicissitudes of the early period have been successfully overcome, their relationship has settled down to a comfortable routine, and is characterized by affection, infornality and mutual dependence.

One theme which might be isolated from this discussion of the household thus for is that the group acts as a self-contained economic unit. Through the custon of early property division it ossumes, almost from the moment of its establishment (with tise notable exception of the wealthy few) primary rights of 
ownership in land. Mlthough other groups may have some residual and/or potenticl cleims, a household is essentially master of its own estate. Thus, it controls its ow income from agriculture and other sources, is responsible for meeting the expenses of sons' marriages and daughters' dowries, as well as recurrent expenditures. It also mailntains a jealous hold on its laboun resources. Beceuse of the nature of relations within the simple family, the father assumes responsibility for household decisions and his authority serves to underline the corporateness of the group.

Household es a Ritual Unit

The household is also the most important ritual unit arnong the Indreni limbus. The deities whose annual worship is regarded as obligatoxy are propitiated by, and for the benefit of, a household group. Roughly, they can be classified into two categories: domestic and forest gods.

The numbers and identity of the fomer vary from one household to the next, but at least four are worshipped universally. The Grandmother goddess 
$(\text { Yuma-samang })^{1}$ is regarded os the mistress of all Limbu deities, and the most ubiquitous and powerful of supernatural beings ${ }^{2}$. $\therefore$ second, the Grandfather god (Theba-samang) is thought of as a hind of consort to the Grandmother goddess. Hlthough the implication of affinity seens obvious, not all Limbus regard him as the husband of the former. Some hold the view that he is unrelated, while otbers suggest that the two are sister and brother. A third domestic deity (Misek) is worshipped as a Funter god, responsible for the protection of and the procuring of food for all the other domestic deities, wile the fourth, (Himsamang), is described as the caretaker of all the lesser domestic gods or, in the words of' one ex-soldier, 'a sergeant major'.

1. She is sometimes called 'Meboreni' (Queen) and propitiated under this name by membors of other castes.

2. Despite her primacy in the Iimbu pantheon the Grandmother goddess is not generally credited with the creation. The majority of Iimbus employ the Nepeli term for God (Bhagwan) when referring to the creator. A few articulate limbus state that one deity, Tagera Ningma-phuma, was responsible for creating the world of nature, while another, Puromi-Yambabi, created all living beings. In a Iimbu text in the Hodgson Collection a reference is made to the former as the 'mine of knowledge' and to another deity, Porok-miha (which may be the same as Puromi) as the instrument of creation', deriving its power from the former. 
Domestic deities are associated with women. 'Men have no gods' say the Limbus. 'Just as a man inherits his father's lands, a woman inherits her mother's gods.' Thus, when o woman marries and comes to live with her husband she brings her deities along, and these become recognized as the gods of the household in which she resides. But because the anger of the gods affects men, women ond children equally, the welfare of the household is believed to depend on the assiouousness with which the group propitiates its deities.

If a woman beers no deughters, then her eldest son should worship her gods after her death, although these would not be inherited, in turn, by his doughters. In practice, few Indreni men without sisters do so, cloiming as their excuse both the expense and the fact that the household is well enough protected by the worship of their wives' gods. 'hen the gods of more than one woman inhabit a hornestead, each set is propitiated separately, elthough generally on tho sene day. Thus, for example, if a household includes a woman and her daughter-in-law, two separate rites will be conducted. Axcluding the four principal deities, every woman is vulnerable to the influence of several 
lesser gods in the pentheon, and so the totel set she worships is likely to differ from that of any other woman.

Like humans, gods require nourishment and propitiation consists in offering a variety of foods, including blood sacrifice, depending on the preferences of any particular deity. The Grandmother goddess is especially partial to pork, and one of any litter born to a sow should be offered to the goddess. There are a number of occasions on which domestic gods should be worshipped, but one annual ritual is obligatory. lost limbus perform this rite in early November, at the comnencement of the paddy and miliet harvests, when they offer the first fruits of the harvest to the gods. At one ritual offering (nowangi) I witnessed, two sets of deities were worshipped, since the household included the second wife of a Kambo man, and his daughter by an earlier marrioge. The wife's gods were dealt with before those of the latter. first to be propitiated were the Eunter god (Tisisek) who wos offered rice, flowers and an egg, and a lesser goddess, given millet and a cock. This part of the ritual was held in the courtyand, since it is believed that these dejties reside outside the dwelling. 
Inside, the first to be propitioted wes the Grondmother goddess, who wes offered cooked rice, millet ond fish. The Grandfather god. was then given rice, millet, fish and a cock, followed by an offering of the same ingredients to a lesser goddess with whom the womon was associated. Finally, the Caretaiker deity (Him-saneng) received a similar variety of food. The process was then repeated, although the second woman's lesser deities were substituted for those of the first.

Despite the relationship of domestic gods to women, men play a key role in these rituals. In addition to the ritual speciolist (phedangma) who conducts the rite and who is always a mole, any sacrifice must be performed by one of the men in the household, since women are prohibited from ritual slaughter. Thus, if a household contains only women, a neighbour, usually an agnate of the woman's husband, will be asked to participate in these rites. Ordinarily, however, aside from the ritual specialist, only household nembers are present when domestic gods are worshipped. Other persons are not invited to participate. The exclusion of outsiaers is represented in the rule that after a homestead has been purified for 
the offering - by re-plestering the floow with o mixture of earth and cow dung - no one other than the household members may enter the dwelling.

Although the household worships as an independent unit, it must still. take account of its place in a wider agnetic group. Hamonious relations among members of a Jineage are deemed necessary to ensure the efficacy of household worship. If a man has caused ill-feeling to exist, whether intentionally or otherwise, it is said that he is considered by the domestic deities to be in a state of impurity (jhutto) and until he is purified he cannot properly effect their propitiation. One ritual specialist explained that 'the bad feelings and disputes of the (Iineage) brothers must be driven away, or the deities will not heed the ritual'. For thjs reason, each occasion for the placation of domestic gods is preceded by a ritual 'to wash away bad feelings' (sarap bagaunu) in the lineage. Prior to the commencement of the nowangi rites referred to above, members of the household recited the names of their Rombo lineage 'brothers', while the ritual specialist poured water on the sround. liorsels or various foods to be offered were then buried to symbolize the end of the state of impurity, and 
thereby enable the homestead dejties to be worshipped. In addition to domestic gods there is olso a complex of forest deities who require ennual propit-iation. These are thought to ininabit the area permanently and to have no special association with women. Tevertheless, their appetites are similar, and the maner of theic worship is the same as for domestic gods, except that the rites are conducted in a field away from the dwelling. Here, too, each household worships as a unit and assumes that its offerings will benefit only the household group. Alternatively, it is this group alone which will suffer the consequences of a deity nade angry by neglect. Indeed, the rationale of worship is to ward off the malevolence of dissatisfied gods. Liach is believed to bring several kinds of misfortune, most frequently in the form of illness, and to strike only when a household ignores its demands or is stingy in its offerings. Fropitiation is not necessarily considered to brine good fortune, but at best to postpone or mitigate bad fortune. The attitude of Ijimbus to their deities (domestic and forest) is suggested by the following legend. 'Some gods were angered by men and set out to kill them. 
But they were met by God (here the riepali terin 'Bhagwan' was used to imply the creator) who said: "If you kill people what will you gain? If you want to be respected by them brins them illness and trouble. When you will be respected. They will give you offerings; they will perform rites; they will always fear you." So the gods did this and now people placate them.'

The range of homested and forest gods does not exhaust the realm of the supernotural. There are other deities which possess malevolent powers, but are conciliated only if they victinize a household. Fror example, all Iuimbu women are said to 'om' a monkey god, a potentially violent deity, but that these are only 'active' in rare instances, and when such a one exists, a permenent shrine must be erected and offerings made annually by the household.

Limbus also share a number of deities with nembers of other cestes. One, the River goddess (Phakurani) is usualy civen an offering in gratitude for special favours received. lhus, when the deughterin-law of one man was ill he promised the River goddess a pigeon if she recovered, which promise was fulfilled several months ofter the wonan regained her health. 
Hithough Iimbu ritual specialists are called to ofriciate at these rituals, concessions are made to the Nepeli character of the Goddess by conducting the rite in the Nepeli languege, and by not offering secrifices (e.g. pigs) which are thought will orfend ber susceptibilities.

Hindu gods, too, are worshipped by some Limbu bousebolds, but for these rituals, Brahmin priests are called.

In addition, a variety of evil spirits inhabit the supernatural world, and pose a constont threat to the well-being of all inhabitents of the area. To - lesser extent witches (bolsi) intrigue to bring about misfortune, and even the nost innocent people can fall victin to their powers. The propitiation of these nelevolent forces, however, is not effected as a matter of course, on a regular and obligatory basis. Their implication in a household's misfortune must first be detemined by divination, and only then can steps be taken to put the matter right. figajn, the point to be noted is that the conciliation of the verious deities and spirits is the task of a household group, which seeks to protect its members from the barnful forces of the super- 
netural world. Since these forces are seen to arfect households, it is the latter and not any wider unit Which acts as a corporate sroup in these rituel contexts.

There are circumstances in which a household may join with others to worship particular deities. Occasionally, a goddess is 'discovered' (usually by divination) to inhobit the banks of a strean or a small wood near some paday fields. Just prior to harvest time, to ensure a successful crop, those cultivating the surrowding fields make offerings to the goddess individually or ia concert. Lt one such offering I observea, eight nen - one on hingu, the rest members of four different chongbung lineases - contributed a total of Rs 20 to purchase a coat for the sacrifice. None of the individugls was obliged to contribute or to take port in the rituel, and it is most unlikely that tho same men would join together the following year for the some purpose since, for one thing, cultivation rights to at least some fields would probobly change hands.

On the moring of the fulj moon or Boisolkh (ipril-May) Indreni inhobitarts gather at five shrines in the Cluster at each of which resides a different 
soddess. kimbun, Ohitol and Dorumbe each contein one, vhile tro are found in Bnarapa. Although these are conceived as settlement deities in fact their worship does not crystallize permanent rituel groups. Each household is free to vorship at the shrine of any of these deities and though nost participate only in the rite of the goddess nearest thejr homestead, sone househclds attend two on even three rites, while others choose to propitiate a different goddess each year. The itinerant worshippers explain that several of the goddesses were revealed in the recent past and so are not believed to possess the same powers as the more established deities. Others, with dry fields in more than one area of the Cluster, attempt to please the goddesses who are most likely to afrect, by reason of propinquity, the fertility of their lands. jome comend the healing powers of certain goddesses. I Limbu of Dorumba, who regularly attends the rite in Angbung, pointed out that his wife had recovered from a serious illneas after he had brought a sacrifice to the goddess in ingbung. is few households without means to contribute to these sacrifices simply opt out of the propitiation rites altogether. In sum, then, even rituals perrorned on beholf 
of large collectivities do not constrain the bousehold to regand itself or act as part of a wider ritual group.

The Iimbu household, despite its 'encapsulation' in a lineage, hes been shown to be a self-contained unit in certain economic and ritual contexts. The 'individuation' of the household, in economic terms ot least, is partly the rosult of land pressure and Govemment policy which, as pointed out earlier, led to the virtual disappearance of the lineage as a corporate group in respect of land, and a corresponding emergence of the household as the group with the greatest interests in that land. But self-containment and individuation do not imply self-sufficiency. The universe of social relationships does not begin and end with the household. This will become evident in the remainder of this essay. One theme I have been concernea to emphasize in this chapter is that the decisions Iimbus make in the course of their daily Iives are affected not so much by the interests of wider structurel sroupings as by those of the household. itself. 


\section{CHAPTER V}

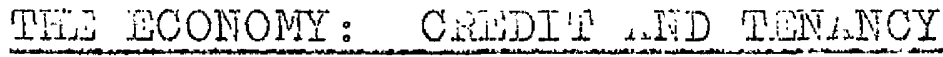

As I showed in Chapter III, Government policy resulted in the reduction of the amount of land under kipat tenure. At the same time, population pressures were increasing on those lands still under Limbu control. By the turn of the century the majority of Iimbus found it impossible to maintein their level of consumption and meet minimal social obligations without resort to borroving from the immigrants to whow they had originally granted a portion of their lands. These latter, whose numbers had increased, were in need of additional lands and denanded, as security for their loens, that the kipat lands of the Limbus be given them under possessory mortgage. In other words, the creditors assumed the rights of usufruot pending repeyment of the loan. The circle wes as cumulative as it was vicious. As they went further into debt the Iimbus vere forced to mortgage more and more land; and as they lost access to their lands, they could not eam enough to repay the mortgages. 
Mortgages

There are two types of mortgage. The first bhop bandhalki - leaves unchanged the amount of capital and enables the mortgegor to repossess the land upon repayment of the amount. The second type (nosikatta) reduces the mortgage capitol by a specific sum each year. This latter type, which applies to $85 \%$ of all mortgage transactions in kipat land, derives froin a kind of nortgage prevalent until 1914, when it was abolished by the Government. Such mortgages enabled the contracting parties to stipulate a period of tine during which the omount of the nortgage would be reduced by an agreed sum annually, and at the end of which the mortgagor would resume the land without further peyment. However, such agreements did not allow the mortgagor to repossess the land before the end of the period, which could extend for as long as 100 years or more. 1 The masikatta mortgage enables the kipat owner to repossess the land at any time upon repayment of the originel capital less the fixed annul reductions ${ }^{2}$.

1. See po. $100-02$.

2. Nasikatte has certain features in common with the kanam system prevalent in Ialabar. Cf. Vayer, 1952, po. 79-81; Kumax, 1965, pp. 23-25. 
In both kinds of nortgage agreement the mortgagee exercises rights of usufruct in the land as long as the loan is outstending. If the mortgagor repays the loan ofter the seed has been sow he must allow the nortgagee to teike the harvest of the land. For his part, the mortgagee may not charge interest on the capital. The former is prevented from taking the land back piecemeal, by paying back the capital in installments. Once pleded, a field is regeroded as a unit, which can only be returned as a unit when the entire capital is repaid as a lump sum ${ }^{1}$. Only when the fiela has been sub-divided among the heirs of the mortgagor, each of the latter can repossess his own share individually. Of the kipat owned by the Limbus in the Indreni settlements, $68.2 \%$ is under ruortgage. The percentage of irrigated land pledged is much higher than that of dry lands. $82.8 \%$ of the forner, which comprise twothirds of all Indreni lands under kipat tenure, have been mortgaged; only $38.6 \%$ of dry londs have been pledged. This is due manly to the fact that a feir

1. This practice does not derive from any mystical notion about the unity of a field, but relates to the increasing costs of cultivating o field which is aiminishing in size as a result of pieceneal repossession. 
proportion of dry lands are homestead plots wich are not mortgaged.

\section{TABLE 9}

Iipat inortgages by land type

Type of land No. of units ${ }^{1}$ Amount Percentage

\begin{tabular}{|c|c|c|c|}
\hline Irrigated & 91,462 & 75,790 & 82.8 \\
\hline Dry & 45,222 & 17,490 & 38.6 \\
\hline Total & 136,684 & 93,280 & 68.29 \\
\hline
\end{tabular}

We see from the figures in the above table that Irimbus in the Indreni settlements have unrestricted rights of usufruct to just under one-thire of their injpat lands. The extent of nortgoging varies from one Iineage to the next (see Table lo).

1. Jee Appendix. 
TABIE 10

Kipat mortgases by Iinesge

Iineage

Chongbung Iineage (I)

Chongbung Iineage (2)

Chongbung Iineage (3)

Chongbung Lineage (4)

Chongbung Isineage (5)

All Chongbung:s

Kambo Lineage (I)

Kambo Iineage (2)

All Kambos

Nembekes

Phatras

Syelings
Eercentege of Land Iiortgaged

60.3

66.5

56.3

76.9

62.7

62.4

90.2

96.5

92.7

61.0

7.5

84.5

Lmong the Chongbungs the comparatively high percentage of lands pledged by Linesge (4) can be explained by the loss of almost half the lineage's paddy lands in a court case half a century o80 ${ }^{1}$. Iireage members were forced to mortgage a good part of their remaining lands to meet the heavy fines imposed at the time, and to mantain subsistence since. The relatively low figure of mor tgagine by Chongbung Lineage (3) is largely the result of repossession of lands which were in fact previously nortgaged. The repossession

1. Soe Chepter VI. 
has been made possible by the importetion of monies from outside the Cluster. By and large, however, the fact that land mortgaging is a cumulative process which has been going on since the late 19th century, makes impossible any precise explanation of the differences in extent of mortgaging among the various Iineages.

TABIE 11

Iipat mortgages by household

Percentage of Kipat Lands Miontgoged

None

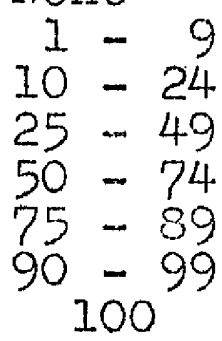

No. of KipotOwning Households
Percentage of Kipat-Owning

Households

Table 11 shows us that almost two-thirds of

1. I include here only households which are potential mortgagors of kipat. This exclures by definition households which ow no lipat. But also excluded are households which, though kipat-owning, are not in a position to mortgage these lends. Tiro bousehold heads have not yet inherited their kipat lands, but have been given, as their (as yet incomplete) inheritance lands taken under mortgage by their father. Three other households are headed by women who have been granted the use of lripat duning the course of their lifetime but cannot transfer these rights to others. I have excluded these five householas from the table. 
kipat-owning Limbu households $(64.7 \%)$ have pledged more than helf their lipat lands. The figure of only one household hoving nortgaged all its kipat lands stresses the tendency for limbus to hold on to homestead sites. Since the figures are for all kipat Iands, they obscure the fact that 39 houselolds (57.3\%) have pledged all their irrigeted lands.

\section{Distribution of Miortgeses}

To whom do the Iinbus pledge their kipat?

By far the great majority of mortgaged lands (72\%) are held by non-limbus. Thus, the first point to note is thet kipat lendowners and Iendholders 1 are, to a large extent, members of different caste groups. A second point to note is the residential spread of the landholders. Just under two-thiras (64.6\%) of mortgaged lends are in the hands of landholders resident outside the Cluster. Settlement boundaries, then, do not define the spatial limits of mortgage relationships. Nevertheless, only a few landholders live beyond a radius of

1. Henceforth, I use 'I mortgagee or pledgee and distinguish this person from the 'Iandowner' and the 'tenant', or person who actually cultivates the land. 
two miles of the mortgaging household. In this category are several kinsmen of Indreni jumbus. One is a shopkeeper living in Ilam Bazar, who is the sister of a non-kipat owning resident of the Cluster; another is the brother of a woman married into the Cluster from a settlenent across the river to the west. i third is a wealthy limbu from the district of Ponchthar in the north, who has interests throughout east Nepal. But these rank as exceptions in that Iimbu kipat owners prefer to have their lanaholders nearby. Indeed, as I point out below, mortgage ties tend to be formed within 'neighbourhoods' - even if these extend beyond cluster boundaries.

TABIE 12

Distribution of mortgoges amons Limbu landholders

Iimbu Landholders Percentoge of Kipat Lind mortgaged

Kipat-owning Limbus resicient in Cluster 17.2 Non-kipat-owning Limbus resident in Cluster Iimbus resident outside the cluster ill Limbus

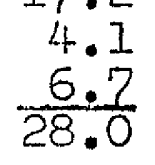

Table 12 gives the distribution of mortgaged lands among Iimbu landholders. It is shown that $21.3 \%$ of all kipat mortgaged is pledged to Isimbus resident in 
the Indreni settrementis. This leoves just under four-fifths in the honds either of Jimbus resident outside the Cluster or members of non-limbu groups. Turning to this latter cotegciy, it is to be noted that members of non-limbu groups resicient in the cluster hold $14.2 \%$ of mortgaged lands, while 57.8\% are pledsed to non-residents. Table 13 gives the distribution of mortgaged lands among non-Iimbus.

\section{TAPIS 13}

Distribution of mortiages among non-Limbu landholders

Jon-Limbu Iandholders

Brahmins resident in Cluster Jaisis resident in Cluster Others resident in Cluster Brahmins and Jaisis resident outside cluster

Others resident outside Cluster All non-iuinbus
Perceatage of Kipat Iand Mortganed

These figures illustrate several points. The pirst is that members of the highest twice-born castes (Brahmins and Jaisis) have taken by far the largest proportion of kipat lands under mortgage. Brahmins and Jaisis between ther hold hali of these leads, while members of other castes hold slightly over one-wifth. secondly, jrahmins and Jaisis resident in the Cluster 
have a much higher proportion of lencholdingis in relation to their numbers then those resiant outside the cluster. Whereas Brabmins and Jaisis in the Cluster represent only $3 \%$ of the total number of Brahmin and Jaisi households in the Villoge area, they heve $3.4 .2 \%$ of the kipat lanaholdings. Pinelly, none of the other non-limbu households in the cluster - there are seven: four Megar and three Blaclismith - have taken any kipat under mortgage.

I proceed now to consider by the use of quentitative data the linkages formed between limbus and those to whom they pleoge their lands. My focus in the discussion will be the individual lripat-owning Iimbu houschold and the pattem of mortgage relationships in which it is involved.

The majority of lijpat lands pleaged are concentrated in the hands of less than a score of landinoldens ${ }^{1}$. These (nimeteen) 'Main lundholdens' - as I shall call then - who have taken $68.8 \%$ of all lands mortgaged, are

1. I innore tive fact that several of these londholders outside the Gluster may heve spanned a few households of soris or younger brothers. ine landholding households within the cluster, however, are hovsenolas in terms of my earlior definition of the word. 
resident nainly in the Clusben on in its innediate environs. Of the nine Indreni landinoldens, six are Brahmins, one is a Jaisi, and tro are Limbus. Five of the ligin Landholders living outsice the cluster are Brakmins, three are limbus - the only ones living at some distance from the Cluster - while one is a Gurunge and one a ITewar.

TABIE 14 Distribution of mortgages among liain Lerdholders

Main Irandholders Residence

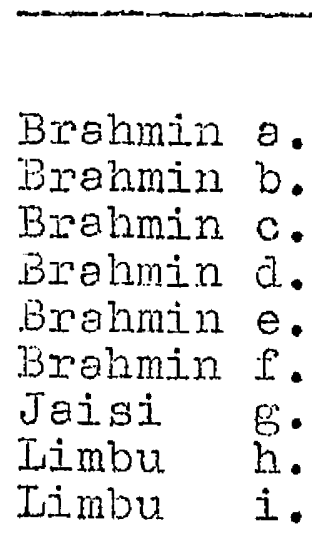

Brahmin $j$. Brahmin $k$. Brehmin I. Brahmin m. Brahmin $n$. Guring 0 . Newar $p$. Limbu $\mathrm{g}$. Limbu r. Iimbu $\mathrm{s}$.
Dorumba jorumba

Chitok

Bharapa

Chitok

Chitok

Dorumba

Chitok

Chitok
Percentage of Ho. of Iink. l'iortgaged Iands ages to Landowners

\section{in Cluster}

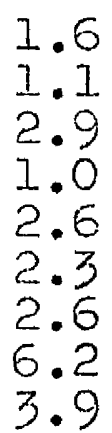

2
8
3
2
6
5
7
16
8

ex-Cluster

$1 \mathrm{mj}$. I of Angbung

I mi. E of singbung

7. mi. S of Angbung

$1 \frac{1}{2}$ mi. S of sngbung

$\frac{1}{2}$ mi. of Chitok

I mi. of Dorumba

$1 \mathrm{mi}$. S of kngbung

Ilam Bazarr

3 mi. it of Cluster Panchthor district
2.7

3.6

4.7

9.6

2.4

10.6

3.6

3.2

1.8

$\frac{2.4}{68.8 \%}$ 
Teble 14 shois that the vain Iandholders are linked in mortgage relotionships with an average of 7.2 Iimbu householas ${ }^{1}$, although the range extends from a minimum of two to $\&$ maximum of seventeen households. Iandholders with the greatest amount of pledged land tend to be tied to the largest number of kipet landowning households. I have given the residential location of each of the Main Iandholders because geoEraphical propinquity appears to be a factor in the formation of mortgage relationships. The kipat owing households tied to the three Dorumba landholders (Brahmins a. and $b$. and Jaisi $\left.g_{\bullet}\right)$, for example, are confined to Dorumbe and that area of Chitok adjacent to Dorumba. Sirnilarly, the landholders resident to the east and south of hngbung have mortgage ties almost exclusively with Iimbu households in that settlement and Bharapa, its neighbour to the north. Only two landholders (Limbu h. and Gurung o.) have links to kipat-owning households in all four Indreni settlements, while

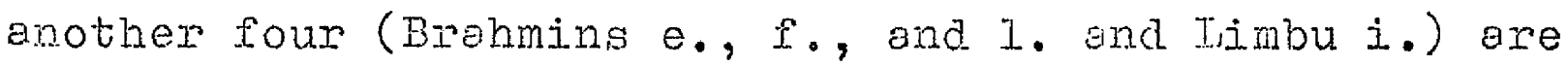

1. I am forced to ignore what night be called the relative weight of each linkage. A landowner may give one field or several to a landholder; the mortgage capital may be great or smell. 'Linkage' obscures these differences. 
Iinked to households jin three sethlewnts. The majority of thirteen hold land omed by Limbus whose residence is locelised in one or two (ajjacent) settlements.

Limbu landowners, for their part, are linked to an averege of four lendholders. This includes linkages to others as well as to the Moin Iandholders. The range of ties per household is shown in Table 15 .

\section{TABDIE 15}

Linkaees to lendholders

No. of Jinkages

To: 1 Iandholder

2 landholders

3 landholäers

4. Iandholders

5 landholders

6 landholders

7 landholders

8 landholders

9 landholders

10 or more londholders
Limbu Kipat-owning Households

18 households

6

6

8

10

3

2

$\frac{1}{4}$

The tendency is for Limbu households to disperse their mortgages, especially if they are heavy, among several landwolders. The eighteen households which are linked to only one landholder (see Table 15) are those whicin have pledged few lands on conversely, have only fev lands to pledge. These eighteen households, 
while they repiesent $30 \%$ of timbu housoholds which have motgaged kipat, account for only $6.6 \%$ of all lands pledged. Twenty-ive of the sixty limbu households pledgins land have concentrated thejr ties among the Nain Iandholders and have formed no mortgage ties with others. Alternatively, only three households have no lints at all to these Main Landholders, but these are anong the households which have only single mortgage links. An aditional twenty-five households have links with landholders other than the Main Iandholders resident outside the Cluster. Woreover, twentytwo households have mortgaged lands to other Iimbu households in the Indreni settlements, excluding the two Iimbu Main Landholders resident in the Cluster. Some of these latter landholder households may at the same time pledge their own kipat to other landholders. Taking the total number of linkages (236) between Iimbu households and their landholders, we find that 59.45: (138) are with the lain Landholders, 21.6\% (50) are with other non-Limbu lendholders, and 19\% (48) are with other Indreni Limbus. The picture, then, is of a series of prongs emenating out from Iimbu kipat-oming housebolds, Iirking them to a wide assortment or landholders. 
Most households heve ties to several lendholders, others to a single one. Pang have ties to limbu landholders who are thenselves nortgagors of kipot. These linkages can be exprossed cienrammetically as follows:

Landholders

Iimbu land-owners/ holders

Limbu households

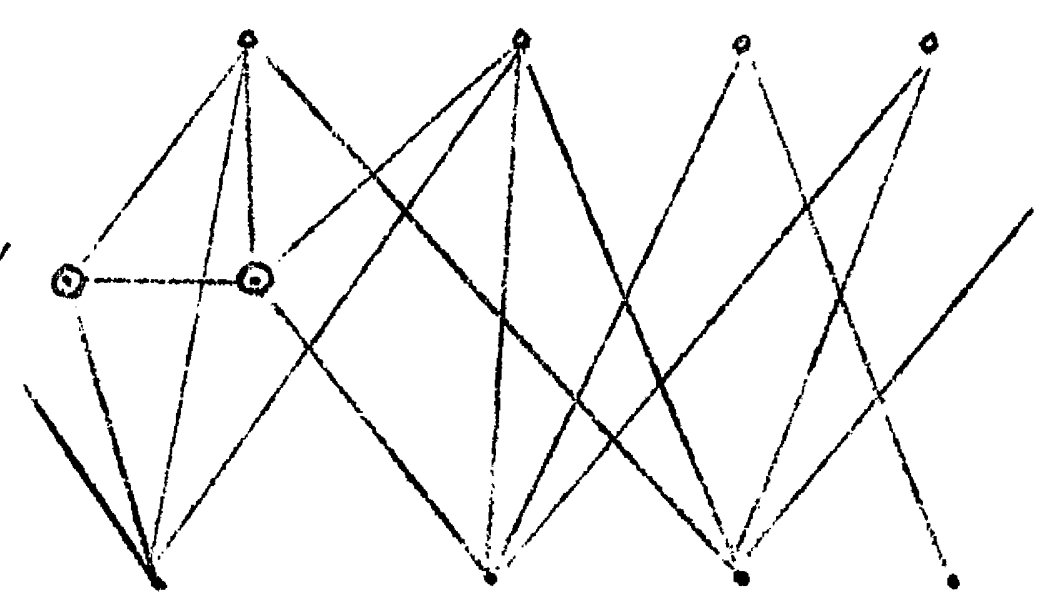

Fig. 5

Is the pledging of land the only means whereby limbus can obtain credit? It is necessary to consider this question in order to discern the range of credit choices available, and the relative inportance of mortgoge credit as compered with loan creath.

1. To avoid confusion in teminology, 'Ioan' will imply interest-bearing loens only, and not loons egeinst which Jands ene pledged, and usurruct transferred to the creditor. 
The aiscussion will olso ottempt to indicate the extent to which loon credit linkeges 'converge' with those formed on the basis of mortgages.

Loan Credit

Loans can be obtained without the necessity of trensferring rights of usufruct to land. Short-term, non-interest bearing loons of smell amounts (sapat) are occagionally given to close kinsmen or neighbours. They require no security and gererally no documents are written to attest to the loan. Irowever, these loans account for only a minuteproportion of loan credit given or received, ond for the purposes of this discussion, this type of loan can be ignored.

Generally, land or other property is put up to secure a loan, but unlike possessory mortgages, the borrower retains possession of the property, forfeiting it (if kipat land, its usufruct) only if he defaults on the payment. Isoans (rin) of this sort bear interest at anywere from 15 - 35\%, although the lew stipulates a maximum of 10\%. A substantial proportion of loans are mede in grajis, and both interest and captal would generally be repaid in kind. sven where cesh loans ore nade, creditors alnost always state the interest 
and require its peyment in quentitios of erain. rhis hos tended to forls egainst the interests of the debtor, since grojn prices have been rising steedily, so tiat, for exanple, a loan negotiatea ten years ago at $20 \%$ interest on the basis of a stipulated quantity of grein, would now bear $30-55 \%$ interest at the present price of the same grain.

The amount of loan credit avoilable is obviously limited by the property which limbus con put up as security. Other than land only jewellery and cattle are aveilable to secure loens. Jewellery usually enters a house as part of a dowry at the tine of or soon after o new wife joins her hueband in bis settlement. Later, if the husband can afford it, she may receive an additional gift of sold or silver omaments. But any jewellery given a women by her natal household remains her personal possession and her husband exercises no cleim to this property. ihe rights of the husband to gifts given by him to his wife is less clear. Most informants suggest that once given, a girt of jevellery could not be telren back duxing the rife's lifetime. But they add thet a good wife would allow the jewellery to be put up as security if the houbehold were in 
serious economic difficuzty. Tiovever, a man's prestige woule suffer if it vere knom that he offered his wile's ornaments to secure a loan.

In any case, fer limbu housoholds mangge to store any substantial wealth in the form of jewellery. fill women would possess silver bracelets; a few would heve silver anklets; but only the vealthiest are able to afford a splendidy carved silver chorm box. The value of silver omments in the Indreni settlements anounts to an average of approximately Rs 80 per household. Ornership of gold jewellery averages ebout $k$ s 200 per hourehold although perhaps halif the Iimbu women hove no nore then o gold nose rinE, and a nostril piece worth about $R_{S} 50$ tosether. Loans are frequently obteined by offering cattle as security. In larcin, 1964 o Subba, after collecting tares for submissjon to the tex office, elitued away the noney during a trip to the plains. In dansen of losing his title, he borrowed Rs 115 against the security of his bullocks. IIe wes given until. Hovemper to repey the loan, and wen he vas unable, the lexdes added anotien Rs 100 and lapt the catile. A fully grown pair of duatht animals can 
fetch up to hs 500 on sale, end a milch cow is worth in the resion of is 350 . The peucity of cettle, hovever, party a function of the cearth of grazing land in the area of the Indreni settewents, limits the anount of credit available on such security. Despite the fact thet draught catile are essential for farming in the Indreni settlements, only 56 out of 85 Limbu households $(65.1 \%)$ possess a pair of bullocks. Sixty-one additional heed of cattle are distributed. among 35 households, while eight householcis share 19 buffaloes. Thus a total of 192 head of cattle are availeble in the Iimbu community, the majority of them elready offered as security.

The Limbus have outstanding; interest-beering debts of approximately is 28,000 . Wher compared with the value of mortgeges which total ebout ris 318,400 , it j.s seen that loan credit is a vory sisell proportion $(8 \%)$ of the total cutstanisig debt ${ }^{1}$.

1. Ten households of non-kipat-owning limbus have outstanding debts or Rs 2980, but since, by definition, they have ino kipat land to mortgage, I ileve omitted these figures tor purposes of comparison. 


\section{D. $31 \mathrm{~L} 16$ \\ Comperison of rortigase and loan credit}

Intorest-bearing loans Mortgage loans (aver. per househola) (ever.per househola)

$\begin{array}{lrr}\text { Chongbung } & \\ \text { Iineage (1) } & \text { Rs } 760 & 6160 \\ \text { Iineage }(2) & 518 & 4302 \\ \text { Iineage }(3) & 238 & 2090 \\ \text { Iineage (4) } & 150 & 2328 \\ \text { Iineage (5) } & 511 & 5590 \\ \text { Kambo } & & \\ \text { Iineage (1) } & 493 & 10048 \\ \text { Iineage }(2) & 328 & 15616 \\ \text { IIembeke } & 553 & 5405 \\ \text { Syeling } & 50 & 3298 \\ \text { Phatra } & 160 & 24\end{array}$

Table 16 compares average mortgages outstanding with loans outstanding by households in each lineage. These figures convey little meaning in themselves without being set against amnul incomes per household. lion the present purpose vhat is significant is the ratio of the two cotegories of debt. In no case is the average credit obtained from interest-bearine loans more than 1.0.95: of the averase hovsebold's total credit (this in Chongbung Iineage (I)). For the syeling households the figure is as low as 1.5\%. Clearly, then, mortgages are by far the primary means of roising money in the Indreni settlements. I have sugsested 
that a scarcity of: security othe: than land mey be part of the reason for the rather lopsided proportions of mortgage and loen credit. But another fector might be mentioned as well. Once land has been mortgaged, a Iimbu con continue to obtain mortgase loans on the security of the sane land, thus obviating the pressures to seek creät elsewhere. This will be discussed in sreater detail at the eno of this chapter. The next step in the analysis, to which I now turn, is a consicieration of the linkages formed by loan credit, and the extent to which they are convergent with those besed on mortgages.

It has been show that only $8 \%$ of all outstanding credit in the Cluster is based on interestbearing losns. Ge would expect, then, that the averege number of ties betweon a borrower househola and its lenders would be fewer than its ties to land-holders. The fact that the borrowing household has an average of 2.5 linkeges to lenders bears this out. Teble 17 gives the brealudow oi linkages. 
TiATJis 17

Linkgries to lenders

INumber of Iinleges Iimbu Borrower Housenolds

To: J. lender

2 lenders

3 lenders

4 lenders

5 lenders

6 lenders
13 housenolds

13 households

12 households

4 households

4 households

2 households

To whet extent do linkages mede with creditors providing interest-bearing loans converge with those formed on the basis of mortgages? A comparison of the distribution of the sources of these two kinds of credit gives us an indication of the degree of overlap. From Table 18 we note that Brabnins resident in the cluster provide almost no credit unless it is secured by land mortgaging. Lhis suggests that Limbus nust seek loan credit outside the ciuster, especially from members of other castes to make up for the lack of non-Limbu lenders in the Indreni settlements. 
TiB B I I 18

Comparison of mortrage and loan credit distribution

Percentage of rortgege Credit Provided
Fercentage of Loan Creait Provided

Limbus in Cluster Iimbus ex CIuster Brahmins in Cluster Jaisis in Cluster Brobmins/Jaisis ex Cluster others ex Cluster
15.5

6.9

12.1

2.4

41.3

21.8
16.9

6.1

.5

2.8

$4 \cdot 4 \cdot 3$

29.6

Since Branmins in the Cluster are part of the Main Landholder cetegory distinguished earlier on, it is essential to know how the category as a whole, which holds approximately $70 \%$ of all kipat mortgaged, fares as a source of loon credit. ihereas the njneteen Maim Landholders provide $71.1 \%$ of all mortgege credit, the sane category yielas only $40 \%$ of loans to Limbu borrowers. Nine of these viain Landholciers, who together provide $20.7 \%$ of the rortgage credit, supply no loens whetsoever. Gix of these persons - five Bramins and one jimbu - are resident in the Cluster. The impression given by these figures is that the two kinds of credit sought by linbus are available only to a Iimited extent from the same sources. The inpression is borne out by an erenination of the total number of 
Iinlrages formed between limbrhouseholds and those supplying loen credit. Only 39.3\% of these linkages are with Wain Landholders. This is to be compared with 59.4\% of mortgage linkages formed with the same category. Iinkages with other limbu lenders in the Cluster account for $19.6 \%$ of the totel - which compares favourably with $19.0 \%$ of mortgage ties. Ties to nonIimbus (other than the Main Landholders) account for $40.9 \%$ of all loan creait linkages, while only $21.6 \%$ of mortgege ties were with this category of creditor. There is some convergence of the two kinds of credit ties with those IMain Landholders who provide loon as well as mortgage credit. Of 50 loan credit linkares formed with these rain Landholciers, almost 40\% converge with those formed for mortgage purposes. Put another way nineteen Limbu households are related to some Main Iandholders both as kipat mortgagors and as borrowers of interest loans. Outsicle the Main Landholding category, convergences of this sort occurred in only tro cases between limbu householas snd other Iimbu lenders. In brier, given a small area of overlep between the two sources of creati, providers of mortgege credit and of loon credit are essentially 
different sections of the populotion in and surrounding the Indreni setblements. The creatt linls emenating from a Jimbu household might be represented diagrammatically as below.

Landholders/Jenders

Iimbu landowners/borrowers landholders/lenders

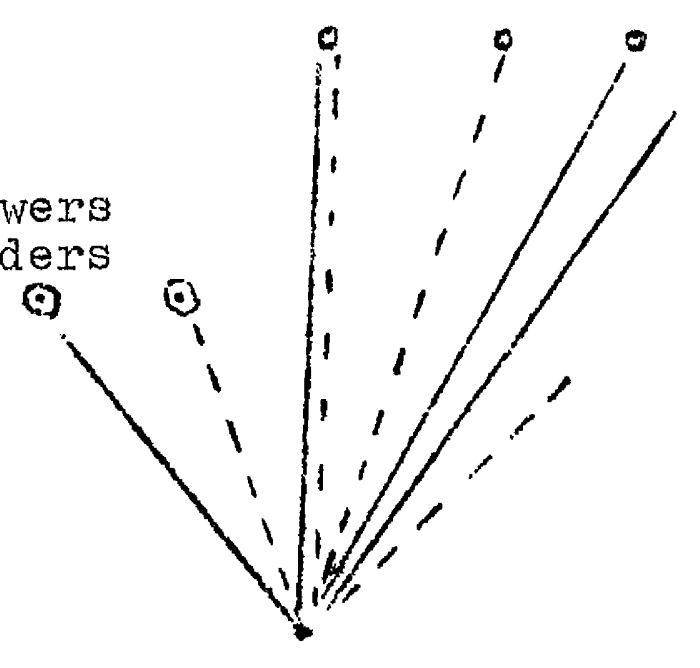

Limbu household

Solid line represents links to landholders Broken line represants links to lenders

Pig. 6

I begen the chepter by a consideration of social relationships created by the mortgaging of kipat land. To determine the relotive importance of other forms of creait it was then necessary to discuss the sources of and linlrages based on loan credit. The next pert of this chapter returns to the exenination of social ties created by other rights in lend. 
Mortgages tronsfer rights of usuruct from the landower to the lendholder. But there still remains the question of who cultivates the land?

\section{Wenancy}

The person to whom land is pledged may choose to cultivate the land himself, or transfer the rights of cultivation to a tenant in return for a share of the crops. Two kinds of tenancy arrangement can be made. The first is an agreement to share equally all the production of a field, including any subsidiary crops. On an irrigeted field, for example, the contracting parties would civide not only the paddy crop, but the lentils which are usually grown in the levees of the terraces. They would even share the straw of the pady. With such an arrangement, the londlord provides at least halin the seed. The second lrind of tenancy, which is the one more commonly practised, is the stipulation of a fixed rent to be paid by the tenent at the time of harvest. The rent is generally a part of the mein crop, but where $a$

1. I use 'landlord' as a generic terr for the person who transfers the rights of cultivation to a tenant. He may be the lendownen, or the lancholden. 
tenont cultivates a dry field, the agrement nay specify payment in either millet or moize. The landlord has no claim on subsidiory crops or straw, although he has inst right to the produce of the land, so that he has a measure of insuronce against a poor harvest. The Iandlord does not provide the seed but he normally pays the costs of transporting the rent from the field to his home.

Thether or not a landholder cultivates a field he takes uncier mortgage depends on a variety of factors. If the land. is near his homestead, the time saved in going to and from the field, and the ease with which manure can be transported to, and the harvest brought from the field will likely make it worthwhile for the landholdex to cultivate the land himself ${ }^{1}$. As well, if the land is adjecent to a field he is already cultivating he will almost centainly cultivate it himself. The additional expenditure of resources required to encompass the adjacent fjeld is considerobly less than the commensurate gaing he can expect. One fector likely to weigh, in favour of hiving the land to

1. Where is also the problen of guerding dry fields, especially against monkeys who sometines destroy a supbstential portion of the noire crop. 
a tenant is the shortage of avoilable lobour in the Househola. But \& wealthy man, especially a Brahmin, even with adequate lebour resources at his commana, is reluctent to send the women in his household to the fields. In either of these situations, agricultural labourers would have to be hired. In such circumstances, the landholder might decide to transfer the cultivation rights to a tenent.

If a landholder chooses to give the kipat land he has taken under mortgage to a tenant, the Iimbu kipat-owner is considered to bave the right of first refusal. The kipat owner may waive these rights or may accept the tenancy and then transfer cultivation rights to a sub-tenant. Phe latter pays the kipat-owner a sinali part of the crop over and above the agreed rent payable to the londholder. Irowadays this practice is rare, and I hove recorded only a dozen instances involving such aouble tenancy?

Occasionally, the kipat omer's right of first refusel is reaffined in the nortgege document. In most instances the landholcers honour the rule and, os

1. Ho avoia confusion, in eny stetistics on tenancy Which rollow, the person actually cultivating the land will be regerded as the tenant. 
I shall point out presentiy, the kipet oyner is often in a position to enforce his claim. Lendholders are seldom reluctant to allow the kipat owner to cultivate the land as a tenent unless he is slow to pay the rent. Some informants state that kipat-owners usually pay less rent when cultivating their own land as tenents than when cultivating land belonging to someone else. My own data on rents do not bear out this stotement. ilents vary considerably from as 'little' as one-quarter of gross production to as much as one-half, and the ronge applies equaliy to ownertenants and stranger-tenants. iNo single reason can expJain the variation. One Limbu explained that he had accepted to pey a rent amounting to 50\% of the main crop because the field was adjacent to another he was already cultivating. There is also the personal factor to be considered: some landholders are known to charge higher rents than others, and tenants of those charging lower rents seldom give up their contracts. When it is found that a Limbu kipatowner is in fact paying a low rent os tenant on his own land, the explanation nay lie in the size of the mortgage. A limbu nay be forced to pledge a field to 
meet an unexpected oblisftion, and accepts far less than the actuel land value in the hope of repaying the ginount quickly and resuming his lend. In such a case, the rent would probebly be e comparatively small proportion of the harvest. The evidence indicates that rents will have the same variation whether the contracting parties are both Iimbus or members of different castes. But the relationship of the individuals con affect the rent. In the only three cases in which the Iimbu landlord and tenant are siblings or father and son, the rents have been in the range of 25\%, and in two of these cases the tenant was not in fact cultivating the land he owned. How are cultivation rights to land mortgaged by Indreni Limbus distributed? Over half (52.5\%) are being worlred by the landholders themselves, while the remaining $47.5 \%$ have been let to tenants. The distribution of mortgoged kipet lano among various categories of tenants is shown in Table 19. Just over 15: of mortgaged lands ore being cultivated by their owners as ienants. Approximately the same amount is being share-cropped by kipat-owning Iimbus who are not, however, the owners of the land they work as tenants. Jimbus who are not kipet owners and other 
Indreni residents (Ragors and Blacismiths) are tenants on $3.1 \%$ of mortgaged lends. the reinainder 15\% - are worked by non-Limbu tenants resident outside the Cluster.

Distribution of cultivation rights on mortgaged lands Cultivators Fercentage of Mortgaged Iond Cultivated

Limbu landholders

ITon-Limbu landholders

The kipat-owners as tenants

Other kipat-owning Jimbus as tenents

Iion-kipat-ownine Limbus as tenents

lion-Iimbus resident in Cluster, as tenants

Ifon-Limbus resident outside Cluster, as tenants

To complete the figures on tenancy, we must also mention how cultivation rights to unmortgaged kipat are assigned. It will be recalled that $31.7 \%$ of all kipet lands are unmortgaged. Of these, 5.2\% are given to non-limbu tenants outside the Indreni cluster, while kipat-owning Limbus cultivate 4.2\% as share-cronpers. The remsining $90.6 \%$ are worked by the kipat-owners themselves. 
re might now exerine the linkoges based on tenancy. Pifty kipat-owning Limbus cultivote kipat land as tenants. Table 20 shows how many landlords they ere linked to.

TABTS 20

\section{Iinkages to landlords}

\$o. of linkages

To: 1 landlord

2 landlords

3 landlords

4 landlords
No. of Limbu Tenant Eouseholds

24 households

19 households

5 households

2 households

Limbu tenent households are linked to an average of 1.5 landlords. Again, the greatest proportion of linkases between tencits and Landlords are with Main Landholders (76.4\%) while $12.9 \%$ are with other kipatowning Limbus in the Indreni Cluster and 10.7\% with other non-limbus. These figures can be compared with those of linkages formed on the basis of mortgages and loon credit mentioned earlier. 


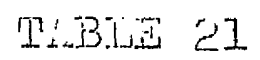

Comporison of distribution of mortgase, tenancy and loan credit linkages

Iinkage rype Fercentage with Fercentage with Percentage with Miajn Iandholders other KO Limbus other non-Iimbu

Nortgage

Tenency

59.4
76.4

Loan Credit

39.3
19.0

12.9

19.6
21.6

10.7

40.9

The comparatively low figures for tenancy linkages with landlords other than the Main Landholders suggests, on the one hand, that the latter, who are by definition the wealthiest londlords, cemot cultivete themselves all the lands they have taken under mortgage. On the other hand, the remaining landloras, to a much greoter extent, take lands under mortsage in order to cultivate these lands themselves, and so are not as able to transfer cultivation rights to limbus.

A hish proportion of tenant households thisty-three out of fifty - cultivate as tenants lands which they own thenselves, and which have been mortgaged to Main Landholders. As well, eleven of these houreholds have borrowed nonios from these same landholders. In such instances, we might speak of double and triple 'convergences', since these households are linked to the same individuals as londowners 
to landholders, tenonts to landlords, and in soine cases as borrowers to lenders. snother kind of linkage might be mentioned. It is thet between a kipat owner and the tenant on his land which has been pledged to a landholder. I have shown in pable 19 that $33.2 \%$ of mortgaged kipat is cultivoted by tenants other than the kipat owner himself. In such cases a tie is created between the kipat owner and the tenant working the land. Where are 34 linkeses of this noture between kipat owners and other Limbu tenants on their land, and a similer number with non-Limbus. The tie is not a direct one in the sense that no paynents are made by one to the other. The relationship is based on different interests in the same land. For one thing, since the kipat owner is considered to have prior claims to tenancy, the rights of a tenant who is not the owner are dependent to a considerable extent on the kipat owner's desire and ability to exercise his claims. Tror another, any change of landholder can influence the security of a tenant, and, es I shall show presently, the limbu kipet-ower is in a position to effect such a change. 
In the foregoing pararophs I have attempted to use quantitative dato ois mortgages, loon credit and tenancy to illustrate the complex pattern of relationships which links Jimbu households both to each other and to members of other castes in the Indreni settlements and the surrounding area. It was found that for mortgages and tenancy the Iimbus are linked to a wide ronge of landholders and londlords. liany of these linkages are concentrated within a small wealthy closs - whose members represent under $4 \%$ of the total Villase household population - and most of whom are Brahmins. Por credit otber than that obtained by pledging land the limbus rely on this class to a lesser extent, casting their net wider, as it were, and creating other linkages to obtain the loans they require.

The limbu household has been viewed as the central point from which emonate severol series of linirgges. Wach series relates to e specificcontext or purpose. The limbu household esteblishes relationships with one or more households from which it obtains loan creait: this is one series. It establishes another on the basis of nortgages, anc a third when it contracts tenancy agreements. Where is jet onother 
serjes creeted out of the latter two: that between owners and tenants. Men superimposed on one another these series of linkages give a picture (at one moment in time) of the range of a household's relationships in, let us say, an economic context. The superimposition reveals a certain anount of convergence in the linkages, so that some kipot-owners are mortgagors, tenants and borrowers to the same individuals. Some are tied to landlords as tenants, and at the same time to other tenants as landlords. The point I an concerned to establish here is that the basic unit in Indreni society - the hovsehold is the focus for a number of linlrages each of which arises in a particular context (nortgage, tenancy) by means of dyadic contracts between the focal household and the individuals or households which compose the series. Some limbu households are liable to have the same terminel points in a porticular series as have other households. Even where the series are not identical there is bound to be a continuous overlapping of linkages emenating from the various Limbu households because of the concentration of mucis wealth in few hends. still, it is unlilely thet the totality of relationships based on a number of linkages sround any 
one household would be identical with those of any other.

Does the totality of linkage series, once formed, show signs of becoming a persistent entity? The question might be directed primarily to series based on mortgege links, since the crucial reletionships, from which those of tenancy and loan credit follow, are bosed on mortgoges. It hos been established that few limbus ore able to repossess their mortgaged lands. Most have inherited kipat already pledged to landholders, and as I will.show in the next chapter current income is barely enough to meet 'normal' obligations, let alone provide enough to repay heavy mortgages. The majority of limbu households remain permanently indebted and their lands permanently under mortgage. Given such conditions, the above question might be phrased in another way: is the relationship between landholder and kipat-otner one in which power resides overwheliningly with the former at the expense of the Jatter?

The Henipulation of Ties

Since 1901 kipat land has not been alienable by sale. Members of other castes with nonies to invest 
in land can purchose only roikor lanci, wich is in short supply. Lis a result its costs have been driven to almost probibitive heights. For many, taking kipat under pledge is the only practical alternative. But since most kipat land is already pledged, the potential landholdex is forced to offer the kipat owner a higher mortgage than that given by the existing landholder. 'Kipat is like a goat', Bramin landholders remerk, 'it goes to the highest bidder'. Since the kipat owner can repossess his lands upon repayment of the mortgoge cepital, the new landholder supplies tisis amount, and an increneat (bard) for the owner. The increment is not a gift, but is added to the mortgage capital. Rights of usufruct are transferred to the new landholder, where they remain until the process is repeated. In this wey, many kipat lands change hands every few years, so that the security of kipat landholders is at best tenuous. This process can be documented by several examples. a) In 1954, Loftone pledged a kipot padjy field to a Brahmin in a wearby setilement outside the Indrenj. Cluster. The mortgage capitel was Rs 960. In 1958, the land. was repossessed by the Limbu and re-pledged to 
a Raj londholder who had added enother Rs 960 bard bringing the mortgoge ceipital to Rs 1920. In 1953, the first Brahmin Iandholder offered to let Loftone have another ks 950 bard for the right of the usufruct on the same land. The latter took the field back from the Rai and re-pledged it to the Brahmin. The mortgage capitel is now hs 2880.

b) Bire nortgaged a paddy field to a Brahmin from a nearby settlement outside the cluster in 1955. Five yeors later a Jaisi offered Bire bard of Rs 240 more than the mortgage capital. The land was taken from the first landholder and transferred to the second. c) In 1926 Suk Bahadur, a Kombo, mortşaged o paddy field for Rs 80 to a Cobbler. Six years later, the younger brother's widow of the decensed Suk Bahadur repossessed the land and tronsferred it to a Brohmin who geve her bard of Rs 50, bringing the capital to RS 130. Five years later the Jancholder was again changed to a Chongbung Iilmbu, who offered Rs 70 bard, thus bringing the capital to Rs 200. The present landbolder, a Joisi, took possession 15 years later by adding $\mathrm{Rs} 200$ to the capital in the form of berd given to Suk Bahadur's heir. 
The decision to transfer kipet from one landholder to another is taken only after the kipot owner is satisfied that the existing landholder will not neet the new offer. since all mortgage holders recognize the potential threat to their security of tenure, the practice has taken root in the viuster whereby landholders accede to Iimbu requests for berd on a regular basis, without waiting until another potential lendholder forces their hand.

The Limbus are thus able to use the ownership of land and their rights of repossession as a wedge to obtain interest-free loans. The Iimbu who owns kipat lons since mortgaged relies on periodic visits to his lendholders for bard to meet contingencies. The most conmon reasons cited for asking bard are househola expenses which generally means food requirements. Funersis, weddings and compensation demends from aggrieved husbands are also occesions for requesting bard. For example, we might follow the history of one mortgase on land given to a Brahmin in 1938 for Rs 128 to cover househola expenses. For the next ten years two Limbu brothers took an average of Rs 90 per year for similer expenses. In 1948 the elder brother died and Rs 80 bord was taken to help 
meet the costs of his funexel. Duxing each of the five years followine an average of is 40 was added to the mortgage capital for household expenses. In 1953 the sol of the younger brother was married ond Rs 144 was borrowed, the anount added to the capital. An average of only hs 32 was taken each of the following five years for the household and in 1959 the widow of the elder brother died. For her funeral expenses Rs 80 was added to the nortgage. During the next five years, until 1964, an average of lis 63 per year was taken for the household. The total value or the mortgage is now $R_{s} 2009$.

Jimbus attenpting to keep mortgages to a minimum in the hope of repossessing theix kipat, of course do everything they can to avoid running up the debt. In such cases mortgage capital may remain level for years, and no attempt is made to play off landholders for the purpose of obtaining berd. But these Iimbus represent a very small minority of the Indreni population.

For most, bord represents an importent source of cepital to close the gap left by insufficient agricultural production. One Iimbu, for example, an old Subba, collected. Ps 576 from seven landholders in 
1963 and, in adition, trensferred a large paddy field to a new landholcer who gave the Limbu bard which increased the mortgage capital by Rs 1600 . The exanple is atypical of the anounts usually obtainable from landholders; but it is representative of the despairing attitude on the part of nost kipatowners towards ever reclaiming their lands. Pew entertain the hope of repejing their mortgages, but realize that in their ownership rishts lies the only opportunity to benefit from lnipet. A variety of practices have been devised to exploit these rights. Limbus with more than one field pledged to a single landholder might request one of these fields as bard, and distribute the capitel on this field among the mortgages on the remaining rields. jome who are tenonts on kipet lands they own will vithhold the rent and regard it as bard to be added to the capital. others desirous of becoming tenants on their kipat will use the threat of repossession and tramsfer in order to pressure an otherwise reluctant lendholder. Placed in such position, landholders must balance the denends of the Limbu kipat-owner against the benefits they derive from continuing to hold the land under mortgage. Unlike the Iimbu owners, many 
of whoin are vinawere of the extent of their indebtedness ${ }^{1}$ and hence unablo to establisin a rational basis for their continued derand.s, most lendholders determine approximate limits beyond which additional payments would bring diminishing returns. Even so, the 'cut-. off' point is constantly chonging as pressures on land increase. In a sense, bard can be seen as a built-in cost index for kipat land. For as its value rises the landholders recognize the increase by giving the kipat-owner these additional loans against security of the land they have already taken under mortgage.

An analysis of 75 kipat histories based on land documents reveals the pottern of increases in mortgage capital due to bard increments. Taking the initial mortgage capital as index 100, twelve histories show that during the first five jears a mortgage is held the capital increase: by an average of between $20-30 \%$ (median value 5 - 10\%). Another eleven histories of

1. This is partially due to the traditional practice of making only one document which is kept by the landholder. For three years now both parties have been required to keep a copy of mortgage agreements, but bard receipts are still kept only by the lencholder. 
kipat land held between 6 - 10 years indicate that by this period the capitel hes risen to an average index of 140 - 150 (nedion index 120 - 130). vighteen histories indicate that the mortgage capital will have risen to an average of just over double the initial cepital between 11 - 15 years after the land was mortgaged (median index 140 - 150). Between 16 20 years after the initial transaction the average index will be 310 - 320 (median 190 - 200) - based on thirteen histories. Fwenty-one histories of land held for the unusually long period of over 20 years shows bora to have driven the capital up to an average index of 470 - 480 (median index $330 \ldots 340$ ). Table 22 summarizes the data.

TABLE 22

Mortgage capital increases due to bard

Perioa ffter Initial

\begin{tabular}{|c|c|c|}
\hline Iortgagie & siverage Index & Median Index \\
\hline $\begin{array}{r}\text { Within } 5 \text { years } \\
6-10 \text { years } \\
11-15 \text { years } \\
16-20 \text { years } \\
\text { Over } 20 \text { years }\end{array}$ & $\begin{array}{l}120-130 \\
140=150 \\
200=210 \\
310=320 \\
470=480\end{array}$ & $\begin{array}{l}105-110 \\
120=130 \\
140=150 \\
190=200 \\
330-340\end{array}$ \\
\hline
\end{tabular}

Based on 75 nortgage histories 
The practice of berd is made possible by the nature of the kipot system of land tenure. Because kipat land is inelienable by sale, the limbus retain the final right of repossession of lands hovever transferred to others. By retention of this right the kipat owner is able to play off competing interests for scarce lends to his orm advantage in a kind of institutionalised extortion. It is not surprising that on more then one occasion I was told that if it were not for bard the Iimbus would have to leave the Indreni Cluster and enigrate to India.

In this chapter I have attempted to show how the Iimbu household is the focus of severol series of relationships based on mortgages, loan credit and tenency. Each linkage represents a dyadic contract entered into between the Jimbu household and a portner it has chosen from a fairly wide range of possibilities. Because of the nature of xipat tenure the persistence of these contractual ties depends on the balence of adventage to be gained by both perties to the contract. In othes words, despite the fact that Iimbus usually fill the subordinate roles in these economic linkages, they are not trapped in the vice of cilentage by those with whom they are linked. The linkoges formeo around 
a housenold ane thereby changing or poised to change. This can be attributed to Iimbi ownersibe of kipet Iand.

I have stressed the element of choice in the contracting of mortgage relationships, and as a byproduct of the latter of loan and tenancy ties as well. But I do not want to create the impression of the Indreni settlements as an open market ploce where land is freely bid for and continuously trensferred in response to market factors. I'here are, of course, restrictions on the freedom of choice to sever existing and form new linkages. The most obvious of these Iimitations is the ract that the Limbus are an economicolly depressed sroup ond as such, depend for a large part of their subsistence on these relationships. The second limiting factor hos already been touched on: it concerms the fact that of the wide range of linkages formed by chy household, many are convergent. Put another way, it might be suggested thot the more inultiplex tise linleges, the less freechom of choice for the kipet-omer to manioulcte relationships based on land. Then the ronge of relationships is extended to include those of lxinghip, neighbourhood and 
politics, the number of converccuces mutiplies. tis the Jimbu household bocowes 'hemed. in' by these relationships, of contract and stetus, its capacity for choice is curtailed.

Before discussine the neture of some of these other ties, still another aspect of the Limbu household's license in contractins social relationships must be consiciered. It pertains to the extent of the household's independence of the agricultural economy and, alternetively, its dependence on outside sources of wealth. 


\section{CIIHPIIR VI

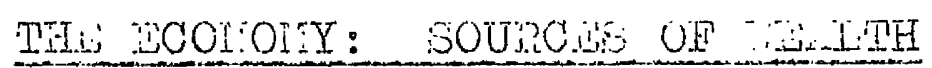

The growth of new opportunities for earning wealth outside the traditional agriculturel economy affects sociel relationships within the Cluster in two woys. In the first place, it has given rise to a small class of wealthy limbus who, to the extent thet they invest this weolth in lond, are displacing Brahnins and members of other castes as landholders. secondly, the exploitation of opportunities outside the agricultural system serves furthex to weaken the ties of dependency on all landlords, which ties, are, as I have shown, in any case mitigated by the prerogatives of kipat ownership. In the beginning of this chapter I consider whether the agricultural economy meets the basic sood requicenents of the household. The various recurrent ard contingent expenses which it must meet are then discussed. Finaly, the sources of 'commercial' income are reviewed and compored with incone from ogriculture.

\section{Agriculture}

Poddy, naize and nillet are the principol crops grown in the Indreni settilements ${ }^{1}$. Peddy - tiere are

1. According to one economist $30.4 \%$ of the totel cultivated area in the country is given up to these crops. (Pent, 1965, p.12). 
as many as twelve varieties grom - is planted in irrigated fields along the terroced slopes of mountainsides, mainly in the lowlands close to river valleys. A comprehensive system of irrigation channels directs the mountain streans into the pady terraces which store the water. During the rirst two weeks of liay, prior to the commencement of the monsoon rains, seed beds are ploughed, inundated, and levelled after which they are seeded and fertilized with green leaves. Five to six weeks later, when the seedlings are about $12^{\prime \prime}$ hish, they are transplonted into the paday fields which have in the meanwhile been preparea as were the seea beds. During September, the fields are weeded and the paday is ready for hervesting in Iovember. Indreni timbus, like most cultivetors in the district grow only one pady crop a year. There is little attempt to plant winter crops for fear of its effects on the pady yield. in few wealthy Iimbu households in Chitok follow Brahmin neighbours in planting small quantities of wheat jn paday lands ot higher elevations. but they heve been able to do so only because of adeguate livestock holdings which enable them to manure the fiejos.

Maize is the chief crop srown in dry fields generally situeted on higher ground, sno moinly on plots 
surrounding homesteads. The fields are first fertilized with o mixture of strow, leeves and wenre, which is then ploughed into the soil. In Morch, with the onset of the brief and internittent spring rains the seed is broadcast. fabout eight weeks after planting and again four or five weeks later the fjelds are weeded. The maize is ready for harvesting in late wugust or early septernber.

Iililet, the third most important crop grown in the Indreni settlements is sown in dry seed beds in July, and transplanted about four weols later. come cultivators plant the seedlings in the shede of the maize stalks, while others prefer to clean a small plot beforehand. One weeding, in september, is sufficient, and the crop is reaped in November.

Households also reserve a sull section of their homestead sites to grov mustard seed, potatoes, squash, cabbage, cauliflover, spinach, punpkin, cucumbers, tonatoes, etc. Bananas are the most comonly kept fruit, while two households have small mandarin sroves. Are Limbus able to depend entirely on the production from the fields they cultivate to meet food requirements? By this term is not meant on objective measure of minimal denands of nutrition. Instead, it emerges from the estimates given by household heads of 
the quantities of rein required daily to feed their fanilies. Of course, this does not ncen that the Iimbu household is always able to provide for its meinbers what it recognizes as their requirenents. When stockss are running low, especielly during July and August, before the maize is ripe, they mey be forced to cut down their food consumption. On the other hend, since the period of greatest shortage comes in the midst of the most denanding agricultural season, the househola will usually borrow if necessary to see itself through the few weeks to the maize harvest. is a result, the estimgtes of food requireinents are a fairly accurate reflection of what the bousehold actually consumes.

The statenents about food requirements made by informents vary little. Adults (esed 14 and over) consune one unit per day or 365 units per year. Children from 10 - 13 yeers are hale-comsumers, while those between 2 - 9 are quarter consuners. The requirements of children under two years are insignificent end can be ifnored.

The 85 Iimbu households in the Indreni cluster require 102,600 units of grain per ennum or on average

1. These consumption figures accord almost exactly with those given by Bałley (1957, pp. 277-78). 
of sligitly more then 1200 units per household.

Kipet lands in the Cluster have a productive capacity of approximately 136,860 units, more than enough to meet food requirements. In adjition, Iimbus ow raikar land with a productive capacity of 8290 units. However, as was shown, a large proportion of kipat land has been mortgaged. Iven so, many of these lands are being cultivated by Limbu tenants. To arrive at the total of agricultural income from lands owned or cultivated by Indreni limbus, we must add together production figures from (a) uniortgoged kipat lands cultivated by the owmers; (b) reikar lands owned and cultivated by Iimbus; (c) mortgaged kipat lands cultivated by Limbu landholders; (d) mortgaged kipat lands cultivated by Iinbu tenants; (e) rajkar lands cultivated by Limbu tenants. To these figures must then be added ( $f$ ) the rent received by Limbu lendlords from non-Iimbu tenants. Finally, froin the total of all these ve subtract $(g)$ the rent paid by Limbu tenants to landlords other than Limbus resident in the Cluster. Table 23 gives tho oppropriete figures. 
Units

a) Irom unmortgaged kipat lends cultivated

b) from roikar lands cultiveteo by Iimbu

c) from mortgaged kipat lands cultivated by

41,150

7,522

a) from mortgaged kipat lands cultivated by Iimbu tenants

e) from raikar lands cultivated by Iimbu

f) rent received by Iimbu landlords from tenant
tenants

g) rent paid by Iimbu tenants to other than non-Iimbu tenants Agricultural income (after rent) Indreni Iimbu landlords - 8.507 87,157

Leaving aside the costs of cultivation, agricultural income after rent amounts to $84.9 \%$ of the food requirements of Iimbu households. This is an aggregate figure for the whole population in the Cluster. The degree to which each household produces its ow food requirements veries considerably. Wwenty-two (25.9\%) households produce more than their minimal food requirements. Another eight housenolds ( $9.5 \%)$ produce just enough to meet these reguirements, while the remaining fiftyfive households (64.6\%) produce less than they require. Table 24 gives the breakdown of households in the Latter caterory. 
TABTH: 24

Production of food requirerents by 'deficit' households

Percentage of Food

Requirements Produced

Under $25 \%$ of requirements $25-49 \%$ of requirements 50 - $74 \%$ of requirenents Over $75 \%$ of requirements
No. of Percentage Households of Households

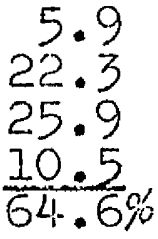

By way of comparison, of the non-Iimbus in the Cluster, all six Brahmin and one Jaisi households produce more than their food requirements. The four Magar and three Blacksmith households, on the other hand, like the majority of Iimbus, produce less than their requirements. Two Blacksmith households produce just over a quarter, while a third yields slightly more than half. One Magar household produces 38\%, another 52\%, a third 65\% and a fourth $89 \%$ of household food requirements for consumption purposes.

Aside from feeding its members, the Limbu household must meet other expenditures. Beginning with recurrent obligations, some of these expenditures are considered in the following paragraphs.

Recurrent Oblipetions

Before considering the household budget and the kinds of consumer itens imported into the Cluster, 
it will be worthwhile noting the number and veriety of retail facilities in the aree, and the xinds of foods they offer for sale. The two shops situated on the main road to the west of the Cluster are hardjy to be considered major comerjcal ventures. Their combined inventory of under Rs 500 only allows for a few items of stationery for local schoolchildren, religious articles, lierosene, tobacco anc paper, sweets and a few staples such as spices, sugar and salt. inhey are visited by Indreni Iirabus only to replenish unexpected shortages and then usually by persons living in the settlements in the immediate vicinity. Most people prefer to combine their shopping with the excitement of market doy in Ilom Bazar.

The Bazoor is only one hour wolk - about three miles - south along the main road from ingbung, the southernwost settlement in the ciuster and just under a two hour walk from the northemmost - Dorumba. On Thursdeys, and to a lesser extent Sundays, hundreds of petty traders from the surrounding settlenentis set up 'shop' in the main square, squatting on blenkets and bamboo mats, to sejl their wares. Shoppers can buy from these small traders as well as from the permanent shops and stalls siturted along the mein street of the Bazaar. There are about ninety such shops and stalls 
offering a wide variety of consumen iters - imported mainly from India - end services.

\section{TiBLE 25 \\ Shops in Ilam Bazaar}

28 cloth shops, most cerry other goods, such as kerosene, sugar, metals, as well.

21 tea stalls, most sell cigarettes and sweets; some also sell liquor clandestinely.

29 genergl shops carrying both western and i-yurvedic medicines, stationery, toys, torches, lanterns, batteries and food staples.

I hardware shop, selling various copper, iron and aluminium cooking vessels.

1 shoe shop.

I watch and torch repair shop.

I 'pharmacy', carrying mainly western patent medicines.

I2 stalls for shoe repairs, tailor, smith, barber, loundry, etc.

It is sometimes argued that exposure to vesterntype consumer goods will create an immediate demand for these articles. To find the means of acquiring these 'targets', the argument goes, potential consumers will bring about profound changes in their work and investment patterns. This is certainly not true of the Limbus. $r n$ inventory of homesteads attests to their indifference to the sreat veriety of merchandise on display each week in the Bazar. There are perheps three torches and the same number of hurricane lanterns in the Cluster. Nedicines, syurvedic or westem, are not bought, umbrellas are only infrequently seen, cosmetics are 
never used. The apparent disinterest in acquiring these goods is undoubtedly related to their costs and/or costs of upkeep. Still, even the wealthiest men seem to prefer investing their monies in land and other socially valued perguisites.

I should not give the impression that all goods available in the Bazars have gone unnoticed by Iimbus. Copper and aluminium cooking vessels hove replaced the earthenware of their forefathers. The women have taken to the brichtly coloured. beads and glass bangles sold in the Bazar. Moreover, in all the household budgets I collected a number of non-durable goods appear regularly. Kerosene, for one thing, is a standard item of expenditure. This fuel is used in the crude lamps - a small tin can containing a wick which provide the only source of indoor lighting. Since few households produce thein requirements of mustord seed, cooking oil must be purchased regularly in the Bazarr. Some of the poorest households gather discarded nuts from the tea plantation on the outskints of the sazaar and crush then for oil. But the amount obtoinable in this way is slight and the taste very bitter. Iobacco and peper count as regular expenditures for most households. Bome of the old men remerber when they smoked earthenware water pjpes, but nowadays all 
roll. their tobacco ia small strips of paper. Spices, soap and tea, only the latter iten grown in Ilam, are regularly purchased on market day.

Since large quantities of salt are required

both for cooking purposes ond for cattle, householas which can afford the cash outlay for bulk purchases go as far as sanisare, a market town in the Terai about two days' walk from the Indreni Cluster. Several household heads, who spent part of the winter of 1965 labouring in the Terai, each purchased out of earnings their annual needs - a maund (80 lbs.) - of salt for $R_{S} 16$, thereby saving themselves as much as $40 \%$ on the retail price in the Bazar.

Meat is the most expensive item in the food budgets of most households. Pork is purchased at least twice a month, and by some, weekly. At the tine I conducted a census, four-fifths of all households had at least one piB, so that part of the demand can be satisfied from within the Cluster. The sacrifice of a pig to the domestic gods is usually accompanied by the sale of its ineat to neighbours. But such sacrifices are intermittent, so that a regurar supply is available only from traders who sell mest on marlket dey. Food items constitute one categony of expendjture by the household. Hor those with children in school 
there are rees ond other school expenses to pay. Fifteen Limbu chilaren from twelve houseiolds were enrolled at the primary school situated between higbung and Bharapa. These represent about one third of Limbu boys aged 6 - 13 years. No Iimbu girls have as yet attended school. Nost boys who were registered in fact attended sporadically, when they were not required to mind cattle or work in the fields. During Perch, 1964, for example, only ten of these children appeared at all at the school and only holf that number attended with regularity, sill, enrollment requires the payment of fees which renge from Rs. 0.80 per month for students in their first year to $R_{S} 1.60$ for those in the fifth (and highest) class. Additional expenses for the parents of school children ore for copy books and pencils, and the contribution of a bundle of thatch and a day's labour for re-roofing the school house each jear.

Households require cash to pay taxes. Limbus in the Indreni settlements pay a total of $2 \mathrm{~s} 327$ in kipat taxej each year, which neans an average of Rs 4.35 per lwipat-owing household. Iine households pay his 29 on raikar lands owned, an average of is 3.25 . Kipet owers who beve mortgeged some of their lands, however, ore entitled to claim a proportion of their 
taxes (damasahi) from the landholders. The amount is determined at the time land is pledged and is written into the deed. The greater the amount of land mortgeged and the nore numerous the number of landholders to whom it is given the larger the damasahi collected. Nany Iimbus with lands mortgaged have thus not only had their tax burden eased, but have in fact been able to turn a profit from this regulation. Eight households with taxes of up to Rs 5 to pay receive more thon $R_{s} 10$ in damasahi payments, one as much as $R_{s} 18.40$. with total taxes of Rs 327 assessed, Iimbus collect approximately $R_{S} 380$ in this wey. On an aggregate basis, then, taxes do not constitute an expense. But not all households receive damasahi, and the amounts received by those who do, are not equally divided. In al1, 35\% of Irimbu households must set aside cash to meet annual tax. obligations.

Budgets allow for substantial expenditure on clothing. Each member of the household expects to be provided with a new set of clothing at least once a year, generally at the time of the Dasain festival in evtumn. Although many limbus in the northern parts of the district, and in Fanchthar, still weave much of their own cloth by hand, Indreni Timbus purchase Indian made cloth in Ilam Bazarr. Despite the appearence of some 
ready-made western style clothes in the Bazar, Iimbus still wear the traditional costume of the hill peasants. To sew their clothes they engage nembers of the Tailor caste.

Traditionally, the Tailor's service was supplied within the context of a relationship of interdependence between client and craftsman. The latter received a fixed amount of grains (bali) at harvest time in return for the services he provided. Moreover, the relationship between railor and client was permanent in that it was transmitted from one generation to the next.

Nowadays, all. but two Iimbu households engage Teilors from settlements in the surrounding area or Ilam Bazber on a piece-work basis, and pay in cash for the sexvices received. With such an arrangement, the household is free to shop arouna for a Tailor whose craftsmanship and prices are most suitoble. Two households prefer to poy their Tailors annually in fixed quantities of greins. But even here the relationship between client and craftsmen is unlike the traditional one in that it must be renewed each year anc the payments determined on the basis of the estimated. requirements of the client. In one cese, the relationship is meintained because it is to the financiel 
advantage of the client who hes a verJ large household. Another limbu client severed such a tie with a Tailor two years ago because he preferred the craftsmenship in the Bazaer to that of his erstwhile Tailor in a neighbouring settlement.

Households also require constant repairs to and replacement of a variety of farming implements and other metel wares. This work is reserved to members of the Blaclismith caste. As with Tailors, the traditional relationship between Blacksmith and client was one of interdependence - a proportion of the harvest in return for services provided. Mowadays, the majority of households engage Blacksmiths on a cash for pieceworl: basis ${ }^{1}$. This even applies to the nine clients of one of the Blacksmiths resident in the Cluster. But whereas only two households retain teiloring services in return for a fixed amount of grain, ten households enter this kind of arronoment with Blacksmiths. The reasons given by the households for preferring an annual payment in grains vary. Some state that payment in a lump surn at harvest time precludes the

1. Relationships with service castes are similar to those described by Farper for the Vielnad Erea viz. the alliances are easily brolien; payments are nainly in cash; the prices of scrvices fluctuate. (Cf. Harper, 1959). 
necessity of finding ready cash which may not be available on each of the occasions when a Blacksmith's services may be required. One informant insisted that it was less expensive to pay a fixed quantity of grains, while several others admitted that the expenso was probably greater, but that it was worthwhile if the craftsman gave good service. The insistence of some Blocksmiths on this form of payment and the dictates of tradition were other reasons offered.

It is the wealthiest households which tend to maintain a relationship based on payment in grains. This is to be expected since only these households are able to commit in advance a fixed quantity of agricultural income. There is, too, a question of prestige jnvolved in maintaining the traditional type of relationship. It does not escape the limbus that a.II Brahmin and Jaisi households in the Cluster prefer this kind of arrangement with both lailors and Blacksmiths ${ }^{1}$. Why more Limbu households have such ties with the latter then with the romer is difficult to

1. Gould points out thet 'the capacity to retain troditional ties with (service castes) marks a household as socially important.' (1964, p.18). 
explain. It may be thet the peilors thenselves prefer to be paid cash Por specific work chone, for I have heard that Toilors who accept an onnual grein allotment are difficult to find.

To the extent that a relationship based on grain payments does exist, it is not akin to the Jajmani tie found in most multi-caste villages of India. For one thing, in a society with only two operative service castes $^{1}$ it seems impossible to speak of a 'jejmani system'. Secondly, the alternative to poyment in grains is everywhere available, and by and large adopted. This latter factor makes even the relationship based on grain payments one of contract, since it can be broken with impunity by either party ${ }^{2}$. Finally, the establishment of a client-craftsman relationship does not radiate out into other spheres. Rights and obligations begin and end within the context of the specific contract. The relationship is single-purpose.

1. There is a third caste of untouchable Cobblers, but their services, when required, are paid for on $\theta$ cash basis only.

2. 'Beidelman reminds us that both iarx and jeber pointed out the importance for the jajmani system of the lack of outside markets for labour or products.' (Kolenda, 1963, p.18). 
In the foregoing peragrephs some recurrent expenditures of limbu householas have been considered. Wealthier households mey spend more on a wider assortment of cormodities or services, but all allow for the purchase of essential consumer need.s. The budgets of two households are given in Table 26. Household 'A' contains two adults and produces only $57 \%$ of its food requirements. Household ' $B$ ' contains three adults and six children aged 1 - 14 years. It produces $152 \%$ of its annual requirements of food.

THBIE 26

Two annual household budgets

Household ' ' H' Household 'B'

Kerosene

Salt

Cooking oil

Soap

Tobacco and paper

Spices

Tea

Meat

Cloth

Tailor services

Metals

Blacksmith services Bchool expenses

Taxes

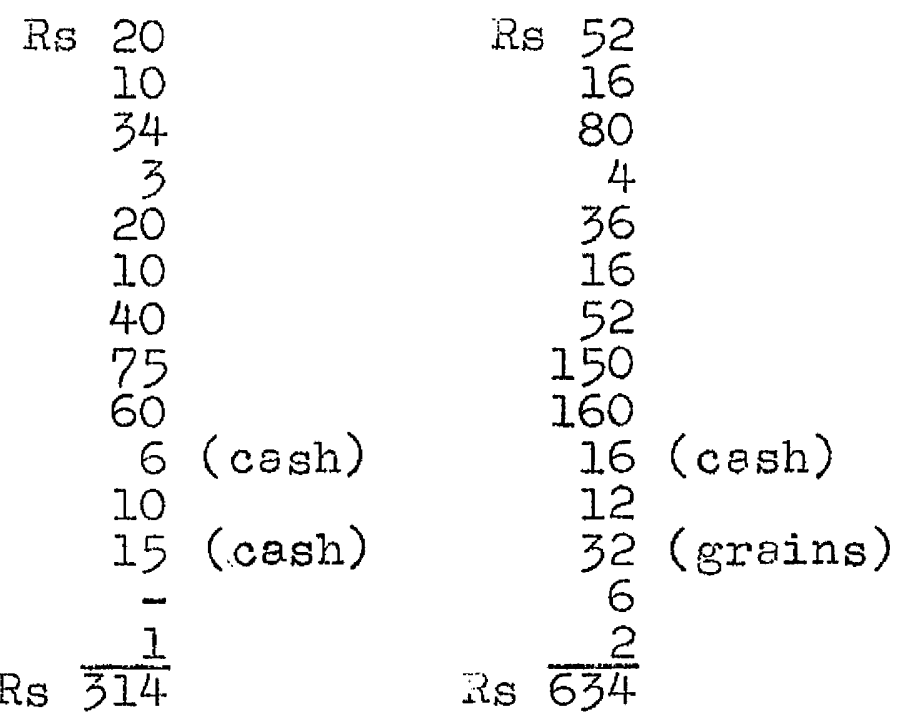


Contingent Expenditures: liortuery izites

There are a number of contingencies which arise, inevitably, in the lifetime of o household. Those which involve the greatest expenditures are marriages and mortuary rites.

The death of a Iimbu renders lineage members ritually polluted for a period of three days if the deceased is a woman, or four if a man. During this period they are required to refrain from eating foods cooked in oil or seasoned with salt. int the end of the period a ritual of 'touching oil and salt' (num tel chunu) is performed to remove the pollution. sit this time the principal mourner (kiriya putra) must give a fesst for those who assisted in the burial rites. However, neither the mourning sequence nor the expense ends there. Iineage members are prevented from propitiating household deities or making marriages until a second ritual is held to signify the cessation of further intercourse between the living members of the lineage and the deceased, and to indicate the return to normal relations between the lineage and the rest of the community. This latter rituel, which is also accompanied by a feast for as meny people as the principal mourner cares to invite, may be held at any time from nine days to a year following the death. 
To avoid the costs and inconvenience of holding two rituals some Iimbus prefer to combine them by repraining from eating prohibited foods for only one meal following the death and then observing the period of pollution from the seventh to the ninth day after the burial. Both rituals are then hela at one time.

The quality and variety of food served at mortuary feasts varies little, being confined to buffalo meat, rice and millet beer. Thus the precise costs of the rites depend mainly on the number of guests. Participation in these rituals is a function of spatial, kinship and status distance between the principal moumer or host and his potential guests. The interplay of these three factors becomes evident on consideration of those to whom invitations (nimto) are given and their response, measured by attendance.

Persons resident in the same neighbourhood as the host are invariably invited to attend mortuary rites and feasts. The host of a rite to be held in fingbung, for example, would expect other residents of the settlement to attend, as well as some from the adjoining settlement of Bharapa. Inhabitants of the two northernmost settlements would not be invited on the grounds of propinquity . 
- The spotial proscrintion or stondance at unoptuary rites is, however, mitigcted by kinship ties. Since Iineage members are required to be present for ritual reasons the degree of their spatial separation from the host is irrelevant. Thus, a rite held following the death of the wife of a Kambo man living in Bharapa was attended by neighbours in Bharapa, nost of whom are Chongbungs and Angus. But his lineage nates, all of whom reside in Chitok and Dorumba also attended, even though members of other groups living in the latter settlements were not invited. Ties of agnation outsiae the lineage are of some importance in determining the range of invitees. Other than Iineage mates, those who share membership of a local clan secment are not ritually affected by a death. Nevertheless, many recognize the loss of an ognate (or his wife) by refraining from eating ritually relevant foods for a single meal. The tie is generally recognized by the invitation of at least some agnates who live beyond the iminediate neighbourhood of the host, provided, of counse, he can effordit. fi wealthy Chongbung man of kingoung, for example, extended invitations to a nortuary rite as far as Chitok, the northemmost limits of chongbung residence in the Cluster. 
Other kinds of ties within the Cluster may be aclnowledged as well. These result from the practice of toxing wives from groups with which affinal ties have already been established. Of the 145 women married into the Indreni CIuster, 62.7\% belong to 30 different local clan segments from 19 settlement clusters within a radius of six miles. The result is that few women narrying into the Indreni Cluster are not already related agnatically to at least some wives of Indreni men. For example, six women of the same local clan segment from one settlement clusier three miles away are married into four Chongbung and one Kambo lineages. The death of an Indreni woman, therefore, obliges the host to invite the dead woman's agnates resjdent in the Indreni settlements, even if ties of agnation do not already exist between the host and. the husbands of these women.

Are members of other castes invited to attend Limbu funerary rites? Aside from a prohibition on the handling of a dead body by non-limbus, there are no ritual restrictions preventing the ettendance of other castes at such rites. At the three rites I witnessed the only non-limbus present were a few Blacksmiths from the neighbourhood who had come, uninvited, to enjoy the feasts. st one rite, in Bharapa, only 
Iimbus were present, although the settlement contains one Brahmin and four lagar households. hhen questioned, the host explained that no Brahmins or llagars were invited because they would not accept cooked food from a Iimbu. Other informants state that members of other castes, excepting Brahmins, have been known to show up at mortuary rites if the Limbu is a close neighbour with whom they have friendly ties. Brahmins will attend, however, only if the Iimbu is a man of comparable status. I'his suggests the existence of what might be called a status barrier to certain kinds of social intercourse, fortifying the existing cleavage along caste lines.

Do distinctions of status similarly affect relationships within the limbu community? Wealth differences alone have little bearing on sociel ties among Iimbus. These differences are irrelevant to the formation of work gangs for cultivation, or friendships, or in attendance at one another's rites. This may be due to the realization that wealth differences are ephemeral and thet the fortunes of a household can change, figuretively speakine, overnight. But jt also accords well with the view which Limbus have of themselves as an egalitarian people. However, where wealth is seen to be more thon temporary, and, 
moreover, where it is accompaniea by other qualities which are universelly hailed and which leed to recognition of the wealthy person as a 'Notable' (bholadmi) the status differences which energe con produce a 'discontinuity' in sociel ties.

Status distinctions are expressed in the absence of a social superior from the mortuary rites of bis inferiors. Attendance implies recognition of the superiority or equality of the host. The conflict of this principle with thet of egalitarianism is resolved by excluding women from the conceptual hierarchy. Thus, one Iimbu who would not attend any of the feasts to which he was invited beceuse the hosts were 'small men' would allow his wile end daughters-in-law to participate while he remained awey with his sons. In sum, the greater a man's status the higher the numbers likely to attend the rites he sponsors.

The participation of affinal relatives is essential for both.prestige and ritulal reasons. The consent of affines is required to remove the pollution of death from a lineage. In addition, whereas no other limbu ritual enjoins the ritual specialist to be related in ony special way to the host, rites following 
a death are thought to be more efficacious if the person officiating is an affine. The Limbus say that 'with an affine (officiating) we are certain that the mourners will be rid of their pollution.'

The essential expenditures for a mortuary rite are the costs of the feast and a new set of clothing for the principal mourner. One household spent Rs 73 to purchase a young male buffalo which was sufficient to feed 100 - 125 people adequately. The guests consumed 65 units of rice at a cost of Rs 78. An additional Rs 20 were expenaed on rice to feed eight affjnes who attended the ritual and were the guests of the host for two days. since two of the guests were related as elder sister's husband to the host, it was also expected. that a goat wovld be sacrificed in their honour. This cost the host on additional Rs 18. The expenses for beer were only $R_{S} 39$ since guests brought gifts of fermented millet, thus providing a substantial proportion of millet needs for the ritual. A new set of clothing for the host, which is put on following the removel of pollution, cost Rs 18. Finelly, a member of the Tailor caste was paid Rs 1.60 to provide music for the occasion. The total expenditure on the mourning rite was in the region of $2 \mathrm{~s} 250$. 
snother rite, attended by about holf the number of guests cost the host Rs 203, while a third, which attracted the same number of guests as the first cost ins 298, mainly because the host did not have time to search around for a smaller buffalo and so ended up buying one larger than he in fact needed. In the latter two instances the entire costs were borne by the household head whose daughter-in-law, in one case, and wife, in another, had died. The expenses in the first instance were shared among three brothers whose classificatory sister, a spinster, had died.

inince the pattern of mortuary rites is standard, costs tend to vary only moderately in accordance with the number of guests attending. This is apparent from the examples above, where the cost of the second rite was only $17 \%$ less than the first, despite the fact that half the number of guests attended. Expenditures on merriages, on the other hand, display a much wider range due to variations in the kinds of marital unions effected.

Gontingent sxpenditures: Marrigge

Limbus marry in three ways: by arrangement (magi biha); by the 'theft' of an unmarried girl (chori biha); or by absconding with another man's 
wife (jari). İo stigme is attached to the latter two forms. Children of arrenged, theft or jeni marriages inherit equally. Nevertheless, arranged mariages are the most prestigous and consequently the most frequent. Of 172 virilocal marriages in the Indreni settlements, $58.7 \%$ were by arrengement, $21.5 \%$ were by theft, and 19.8\% were jari marriages ${ }^{1}$. T'wo-thirds of all narried men in the Cluster have been married only once. Their marriages are shown in Table 27.

TABID 27

Distribution of marrieses involving men married once

By arrangement

By theft

By jari

$66.6 \%$

$20.0 \%$

$13.3 \%$

The following Table gives the distribution of marriages involving twenty-eight men who have narried more than once.

The IE 28

Distribution of marriages involving men married more than once

Firct liseriages

Subsequent Marriages

By arrongement

By theft

By jari

$68.4 \%$

$18.4 \%$

$13.2 \%$
$44.0 \%$

$25.5 \%$

$30.5 \%$

1. I count only those marriages of which at least one spouse is still alive. 
Clearly, what energes from these figures is that a significant majority of Limbus marry their first wives by arrengement, but that subsequent narriages are more frequently effected by thert or jexi. There is no indication that the proportion of first marriages by arrangement is higher among eldest sons than omong their junior siblings. Of 33 eldest brothers (excluding only sons), $63.7 \%$ married their first wives by arrongement, while of 39 younger brothers the proportion is $64.1 \%$. Altogether of 113 marnied men in the Cluster, twenty-two have married twice, eleven men have had three wives and five nen have married four times. But despite the fact that one third of Indreni men have had more than one wife, only four men heve more than one wife living with them in the Cluster. Four others have two wives but in each case one has separated and is living in her natal settlement.

The low incidence of polygamous unions can be related directly to the high cost of marriages ${ }^{1}$. Arronged marriage is the rost expensive of the three forms. Traditionally, becouse marriage took place at an early age, the task of finding a wife hed been the responsibility of the boy's guardian, usually his father. However, during the lifetime of a single generation the average age at which young men tend to marry has 
increased by about four yeans - to eighteen. This has resulted in greater pressure by the young men on their elders to negotiate for partners they have already seen and chosen for thenselves. Young men frequently have occasion to visit the settlements of their relatives and at such times mix freely at dences with the local girls. In 1964 a young Chongbung men was married to a girl he had first seen in 1962 when he attended the weding of his father's brother's wife's brother. Since that time he had mode a number of visits to her settlement in the company of other Indreni boys. Wen it came time for him to marry he informed his father of his choice. lihe latter agreed and set in motion the machinery for marriage negotiations. The elders tend not to disagree with the preferences of the young men so long as the household of the prospective bride is of approximately equal status to that of the groom. Hccording to the wealthiest Iimbu in the Cluster: The character of a big (i.e. rich) household differs from that of a small one, since there is much housework to do, many guests to feed, visitors who must be given tea, and so on. For these reasons the people of a big household do not like to take a daughter-in-law from a small household. And a boy from a very poor family does not come to ask for the daughter 
of a rich man, since he could not neke tho necessary payments or provide for her in the way she has known before. She would soon run away.'

Before taking any formal initiative in marriage negotiations the boy's side will make discreet approaches, often through persons related to both sides, to determine the attitudes of the girl's family to the proposed union. Having ascertained what amounts to a tentative agreement from the other side, the young man's representatives travel to the home of the girl to conduct the formal, detailed negotiations.

It is considered proper for the marriage of a young man to be made by his agnates, more specifically, the senior agnate in whose household he resides. This is not always what in fact happens. Circumstances may lead to a boy being brought up in his mother's natal home. In such cases, the costs of the marriage will be borne by the nother's brother, although this tends to compromise the joung man's prostige, and that of his close agnates. Because of this a young men brought up in his mother's natal home will strive in every way possible to find the monies needed for the marriage himself. In one instence, outside sources of income enablea on Indreni nan raised by his mother's brother 
to provide the costs of his om mawige, a fact he was most anxious to stress.

\section{Bridewealth (sunauli) is paid to the girl's} household immediately the marriase proposel made by the groom's representatives has been accepted. The size of the payment depends on two main factors. The first pertains to the wealth ond status of the groups being united. The average of bridewealth poyments made during the past decade by households in the lower half of the economic scale amounts to Rs 110 which is approximately $68 \%$ of the average payments - (Rs 160) - made during the same period by those in the top half of the scale. Although I could not bear this out statistically, it appears that if a young man succeeds in his proposals of marriage to a girl from a household which is far better off economically than his own, the bridewealth he will be obliged to pay will be at least as high as that demanded of a household on the same economic level as the girl's. In the only two instances of this nature which I was able to document, the bridewealth payments were $\vec{R}_{s} 192$ in one case and $R_{s} 224$ in the other. Thus, in both cases they were above the averege paid by houscholds in the highest economic bracket. This would suggest that where the bride belongs to the economically 
better off household, bridewealth peyments are related to the wealth of her household and not the groom's. The second determinant of the size of bridewealth payments reletes to whether or not the bride has already been married. Iimbus allow widow remarriage and there is no difference in status within the household or community between a wife married as a virgin and one taken in widowhood. The natal household of a widow, however, receives a smaller bridewealth. One wealthy Indreni resident paid $R$ s 128 in bridewealth for a widow who four years earlier had been given as a virgin to her first husband for Rs 176. Hnother was married. for the first time to a nubile girl for whom bridewealth of Rs 150 was paid. Later the same year he was married again, this time to a widow for whom Rs 80 was asked. If a widow wishes it, she may, but is not obliged to marry her late husband's younger brother. If she does no bridewealth need be paid by the second husband although certain other marriage payments (rit) would be demanded (see following pages). There were two such cases of widow inheritence in the Indreni settlements. The rule applies only to real and not classificatory younger brothers who vould have to pay bridewealth anew. Marrying a dead wife's younger sister is also 
permitted. However, there is no obligotion on the part of the woman's group to provide another wife following the death of the first. The first marriage of a Chongbung man in 1935 cane to a ropid end when his wife died only a month after he hod paid Rs 40 bridewealth to her father. He could neither claim the return of the money nor her replacement by another woman from her natal household. Still, some groups seek to reinforce their fledgling relations by arranging for the provision of a younger sister of the dead woman as a new wife. In such cases, bridewealth is paid for the second wife, as well, although the amount demanded by the woman's household for the second would be less than for the first. Two Indreni men married their dead wife's older sisters, which is considered to be an unsivoury practice. To neutralize the 'sin' (pap) a special payment, regarded as a fine, is given by the groom to her household.

Apart from paying bridewealth, the groom is required to make a number of other payments (rit) in cash, meat and liquor?. Some of the rit poyments, like bridewealth, are retained entirely by the household of

1. For reasons of convenience I distinguish, as do the Iimbus, between bridewealth (sunauli) and other payments (rit). 
the bride. The remeinder is shared among her lineage mates and their wives, wile the tie to iner mother's brother is also recognized. These payments are sent to the bride's home the dey following the wedding festivities which are held in the groom's settlement. The quantitjes transported require three or four young men to carry them and the journey can take up to two days. To present the payments an elder must accompany the party and act as its spokesman on their arrival at the bride's home. The groom's father must undertake to pay the road expenses of the entire party. Table 29 records the rit payments made by an Indreni groom in 1965.

TABIF 29 Rit payments at one narriage 1

a) Fee to bride's father on arrival at his home

b) Whole pig for bride's father, plus Ris 1.60

c) One thigh of buffalo for bride's paternal

a) One thigh of buffalo for bride's father

e) For bride's iather's brother

f) For bride's fother's mother

g) For bride's grondfather's sister

h) For bride's linother's brother

i) Ior subba of bride's linease granderather

Rs 1.60 81.60 10.00 10.00 1.40 1.40 1.40 1.40 2.00 4.00 1.60

k) Tor wives of above lineage agnates

1) Fee to bride's father on entry of groom into house

m) Costs of meat (perengo)

n) Costs of liquor

o) Costs of transporting rit

Costs of rit

1. Wach of payments $(\mathrm{c}-\mathrm{k})$ is accompanied by a small wicker purse (perengo) containing about one-half pound of pig meat. The equivalent of about one pint of liquor (raksj) would also be added to each payment. The bride's household received twenty pints. The costs of meat and liquor appear as separate itens (m) and (i). 
The rit payments recorded in the above Table are about averoge. The renge is from Rs 150 to Rs 225.

Marriage payments extend over a period of three years. The Limbu husband returns to the bride's natal settlement each year during the festival of Dasein to make obeisance to his wife's father and his lineage mates. On each of these occasions he brings meat a whole pig plus perengo - and liquor on a scole equal to the initial rit payments made at the time of the marriage. The fees to lineage agnates and their wives need not be paid again, although these relatives continue to receive perengo and liquor. The expenses of transporting the payments are of course recurrent. The costs for each of these three annual payments for the husband whose expenses are listed in Table 29 would thus amount to Rs 168.60 (items b, c, d, m, n, o) or a total of Rs 505.80 over the three year period. This would mean that all rit payments amount to Rs 691.60 (i.e. Rs 185.80 plus Rs 505.80).

Bridewealth and rit payments for a theft marriage follow the same pattern as those in arranged marriages and amount to approximately the same. The husband of a woman married without the prior consent of her guardian also continues payments over a three year period. One 
additional and non-recurring paynent is made to the bride's household at the time bridewealthis transferred. Theft of a wife calls for a fine of Rs 10 - 20 because, say the girl's kinsmen, 'our roof has been broken'.

Marriage by thert eludes the costs of wedding festivities, which constitute the heaviest item of expenditure in srranged unions". is with mortuary rites, attendance and hence costs are related to factors of residence, kinship and status. Members of other caste groups do not, as a rule, attend limbu weddings. Ht one wedding witneased in Dorumba only Iimbus were present, although Dorumba runs into a setilement which is heavily populated by other castes. ist another, in Angbung, a Newar, the ritual friend (mit) of the groom's father was the only non-Iimbu present. The host in the first instance was a poor man; in the latter o mon of above average wealth. Only in Chitok, at the wedding of the grandson of the Cluster's richest limbu, were all castes, including the area's most distinguished Brahins, in atcendance. Their presence attested to the prominence of the host, not merely because of his wealth, but because his status transcended both caste and stealing a bride the high cost of wedding festivities. 
settlement boundaries. He is recognized as a 'notable' in the wider community.

To feed his 300 Limbu guests from every part of the Cluster and the dozen or so specially invited kinsmen from other settlements necessitated the slaughter of a buffolo costing Rs 288. The presence of about 25 members of other castes who do not eat buffelo meat required that a goat priced at $\mathrm{Rs} 30$ be slaughtered. Rice and millet beer added another Rs 285 to the expnnses. Fees totalling Rs 45 were given to the musicians and the Tailor who prepared the bride's clothes and whose blessing (asik) is thought to be auspicious for the couple. The cloth he sewed for the bride, whichwas a gift from the groom, amounted to Rs 55, while the new tunic required by the latter cost onother Rs 30 .

A variety of minor payments were also made to the twelve women accompanying the bride to the wedding. These women (lokanti), who are both agnates and lineage wives, represent the bride's household and kin group and must be treated with great deference throughout the festivities. The initial hostility of the two groups being united is symbolized in the spatial separation of the bride and her party of women from the groom's house on their arrival. They spend their 
first night in a specially constructed shelter ( dera) out of sight of the house where the wedding is to telre place. Fere they are fed ond entertained and indulged their right to insult the groom and his relatives in a highly formelized manner, which brings only abject pleas for forgiveness from the latter. Entrance to the shelter demanded a poyment of Rs 3 , and on their removel the following day to the groom's house for the wedding rite an additional payment of the same amount was given. Following the wedding rite the women, now classed as affines, were entitled to the respect relatives by marriage must be given. In lieu of a special feast for the women, they received $R_{s} 8$ in addition to a payment of $R s 12$ for their expenses on the return trip.

The actual wedding rite (Iagan) necessitated the sacrifice of a cock and hen $\left(R_{s} 8\right)$ and the presentation by the groom of Rs 2 in cash and a necklace of glass beads (Rs 5) to the bride. Hnother Rs 3 was given to the officiating ritual specialist who was the groom's classificatory grandfather.

Immediately following the vedding rite the deity which watches over the welfare of the household must be placated. This is effected by men beating on 
goatskin drums in a set rhythmic patem while circumanbulating the main post of the groom's house, at the base of which the deity resides. These drumers, who are Limbus ${ }^{1}$, come, uninvited from settlements as far as eight to ten miles away, to express the interest of all Limbus in the union of the young couple and their respective kin groups. Beven arummers from as many settlements appeared at the wedding in Chitok. For their attendence a fee totalling Rs 10 in cash and meat was paid. The itemized costs of the wedding festivities were thus as follows:

\section{TABLE 30}

Costs of wedding festivities

Buffalo

Goat

Rice

Millet

Fees to Tailor (and musicians)

Bride's clothing

Groom's clothing

Marriage rite

Payments to Limbu drumers

Payments to women escorting bride

Total
Rs 288

30

175

110

45

55

30

18

10

26

Because of the status of the host the number of guests attending was far higher than the average for

1. They are to be distinguished from the Toilors who ore musicians (and drumers) hired to provide enterteinment at weddings. 
Indreni weddings. Consequently, the costs of wedding festivities in this case vere about $20 \%$ higher than the average expenditure. Still, once an arranced marriage hes been deciked upon, there is a minimum standard of largesse expected from the host, however humble his neans or status. The lowest cost I have recorded for wedding festivities during the past decade is Rs 335, for the marriage of an Angu of less than aversge wealth and with a naxrow range of kin ties, thus making possible a comparatively low a itendance figure of just under 100 guests.

To help meet the costs of weding feasts, guests bring contributions of cash (chanda). The amounts are recorded and reciprocal donations are expected. from the host when he is invited to attend the weddings of his guests' sons ond brothers. Bighty-three households contributed Rs 240 to the costs of the wedding in Chitok. This is slightly higher than the average volume of contributions, which normally cover about 15\% of the expenses.

The least expensive way of obtajning a marriage partner is by absconding with another man's wife. The costs of a jari marriace are, by and lerge, confined to the amount of compensation (jarilial) the new husband pays 
to the cuckolded husband. Compensation must be paid for violation of a man's monopoly of sexual rights to his wife. A husband can, of his om accord, dispose of these richts by taking part in a ceremony in which he symbolically removes the red powder (sidur) from the forehead of his wife, and thereby signifies an end to the marriage. In the only case of this nature in the Cluster, the womon was barren and her husbend was anxious to be rid of her so that he coula take another wife. He wrote a docunent in the presence of witnesses claiming that if she became another man's wife he would meke no demands for compensation. Divorce is extremely unusual since it involves renunciation of sexual rights and the companion rights to cleim compensation ${ }^{1}$. Compensation rates are to a large degree determined by the negotiating skills of those representing the offended and offending husbends ${ }^{2}$. The former try to recoup as large a proportion of the narriage costs as they con. in Iimbu who had spent a totel of Rs 1280 on his marriage was able to get only Rs 480 when his wife went off with another man three years later. In another instance a wornon married by jeri left her Indreni

1. For the case of a womon who attempted - unsuccessfully to obtain a divorce, see pp. $136 \mathrm{fe}$.

2. See pp. 313 ff. 
husband two jeass laten to live with onother nan. The Indreni husband, who hed paid compensation of tis 640 in 1959, collected is 400 when she left bim in 1961. This process of 'devaluation' of women is recomized in compensation claims. The greater the number of men with whom a women absconds the lower the compensation that need be paid for her. Indeed, the old Iaw Code stipulated that o woman who absconds for the third time is considered a whore (besye) and no compensation can be claimed by the last cuckold". The least anount of compensation paid for a women inarried by jari into the Indreni Cluster amounted to Rs 40. The Indreni men is her third husband, and the second she bos married by jari. The average anount of compensation paid by Indreni men for their jari marriages during the post ten years amounts to $R_{S} 435$.

After compensation has been paid the new husband mokes token obeisance to his ather-in-law by presenting the latter and his lineage mates with some reat and Iiquor, the costs of which seldom anount to more than Rs 40 - 50. He does not pay bridewealth or other nit payments. Nor are visits to his in-laws during Dasein obligatory for the three year period, although most

1. Lew Code (Muluki 4in), 1935 edition. This has been replaced by a revised code introduced in 1963. 
Inareni itmbus do malse the trip along with small offerings at least once.

\section{TABLE 31}

Comparative marriage costs

Type of Marriage

Arranged Morriages

Theft Marrieges

Jori Marriages
Range of Costs

R.S $950-1400$

$650-950$

$300-500$

In sum, then, jari is the least expensive form of Iimbu marriage. Roughly, its costs amount to one-third of those for arrmged narriages and half those of theft marriages (see Table 31). The considerable costs of marrigge are made evident when we note that the average annual income from agriculture of the lowest $50 \%$ of Indreni limbu households omounts to Rs 500, while the figure for the top 50\% is Rs 1900. The new Law Code, introduced in 1963, in on attempt to discourage jari practices, sets a compensation figure of up to Rs 1000 or five years' imprisonment if the cuckold chooses to bring charges. So for, Limbu reluctance to use the courts in dealing with compensation cloims has left unaffected the amounts transferred. But this law is one of the few in the new Code with which the limbus are conversant and the threat of court action could yet 
become a potent weapon in the hands of the aggrieved husband.

One other kind of narriace expenditure, the dowry given married doughters, should be nentioned. A dowry (deijo) is usually given severol years following a marriase, after alI the marriage peyments have been completed, and when one or two children have been born. In the case of a wealthy household several hunored rupees or their equivalent in cattle or jewellery may be given. Mostly, however, dowries to Indreni women are small, consisting of some household utensils and between Jis 25 - 50 in cesh. Since lineage agnates receive a share of marriage payments given for a girl, they also contribute to the cost of her dowry, thus relieving what little burden there is on the girl's household. In consequence, the marriage of a daughter is regarded not as an ecomomic disaster, but as an event bringing the household temporary but much welcomed gains. 'Ve Limbus', they say, 'sell our daughters in order to eat. 11

The costs of a son's merriage, on the other hand, must be borne entirely by the houseluold in which the boy resides. Only the contributions of wedding

1. In contradistinction, a Brahmin with many daughters is a much pitied man. 
guests relieve the burden slichtly. The jineage, or even the sibling group - unless jt constitutes a single household - does not share in the expenditure. sis with mortuary rites, marriages of sons emphasize the independence of the household as an economic unit.

In the preceding section I have discussed a few of the obligations which a household must be prepared to meet during its lifetime. Some are recurrent, to be discharged weekly, monthly or annually. Others, like mortuary rites and marriages, are contingencies, and impose a temporaxy but considerable financial burden on the Iimbu household. To meet these expenditures and to fill the gop between agricultural production and food requirenents, the great majority of Iimbu households must rely on income from sources other then the fields they cultivate themselves. Vealth cen be earned locally, from 'comnercial' sources both within and in the vicinity of the Indreni Cluster, and extemolly, through militory service.

Commeroial Sources: within the CIuster

is primary source of income within the immediate area of the Indreni settlements is agricultural labour for woges. To determine the need for this kind of labour it is first of all necessary to inquire into the 
ability of the household to manage its cultivation tosks unassisted.

The household cen llande most stages of maize and millet cultivation on its own. Since the fields are usually within easy reach of the cultivator's homestead, the work can be done at a leisurely pace. The growing of maize and millet is further simplified by the fact thet men and women can perform the same labour, except ploughing. Only if the household possesses no bullocks for ploughing or if it works many lands does it require more than a few outside hands to help in the various tasks. The typical scene between March and June, when maize is planted and weeded, and again in late sugust and early September, during the noize harvesting and millet planting season, is of household groups working with only a minimum of assistance in their separate fields.

The picture changes rodically in June and July, and again in November, for the cycle of pady cultivation. Because of the pressures of a limited planting and hervesting season, a great many tasks must be perm formed in a short spon of time. During the days prior to a planting, the field has to be ploughed and the terrace walls cleared of grasses and weeds so that 
they will attract no insects or mice, and so that the grasses act as fertilizer, since no other is used. The latter work is performed mainly by women. When it is completed the terraces are flooded. On the day prior to the planting, women remove the paddy seedlings from the seed bed and tie them in bundles which con be easily corried or thrown to the planters.

At plenting, time, the ploughmen first turn and level the flooded terraces. They are followed by men whose job it is to complete the levelling of the mudded terraces with hand-hoes and repair and reinforce the levees broken by the ploughs and levellers. Women then plant the seedlings, working in cllusters of two or three to a terrace. Several other women are required to keep them supplied with seedlings. At harvest tine, a fairly rigid division of labour is again evident. Members of both sexes share the job of cutting the poddy stalks which are left to dry in the sun for about four days. The stalks are then bundled by men and carried, mainly by women, to a terrace which has been cleared and levelled for threshing. Whe stalks are piled in a mound and left to dry for about a week. The job of threshing and winnowing is left to the men, who are assisted by the women in 
bringing the grain to their homes. Transporting the bundles of straw is left mainly to the women.

In view of this eloborate division of tasks and the pressures of time, the household requires a labour force which it is unoble to provide from its own resources. To produce the 790 units of paddy which is the average for the 63 Iimbu households cultivating this crop requires approximately 46 male and 50 female labour days for planting and harvesting alone. The household obtains the assistance it needs to cultivate its fields through the recruitment of labour gangs. Each of the gangs is formed for the performance of a particular task and dissolves upon its completion. Planning in advance is necessary because cormitments to join a gang on a specific date are on a 'first come first served' principle, and no man can claim prior rights to commend the labour resources of any other househola than his own. Since there is a potential Limbu work force of only 257 persons (12 - 60 years) the need for coordination is evident.

The great majority of these gangs are recruited on the basis of mutual exchange of labour (pereli). The system is preferred by all who have lobour to exchange since it obviates the need to trensfer scarce cash. Irabour exchenges are strictly reciprocal, however, 
and each household keeps its account of the number of labour days it is owed and owes ${ }^{1}$. There is a recognized scale of job equivalents, so that, for example, a household without draught animals will have to exchange three days of plonting for one day of ploughing. These equivalents, however, relote only to jobs and not to the ability of the inaividuals performing them. So that a young girl con be sent to repay the labour given by a strong young man, as long as the jobs are considered on a par with each other. Labour exchanges need not be immediate: a lobour debt incurred at the time of paddy planting may be repaid at harvest time. The sanctions for fulfilling lobour obligations are the need to depend on others for similar assistance and foilure to meet lobour debts would mesn no further help for the recalcitrant household.

Despite the fact that pady fields are scattered. and situated at some distance from homestead sites, labour is exchanged not with those who cultivate adjoining fields, but with settlement neighbours. Only seldom are the tiro coincidental. Iinkages arong households exchangine labour only occasionally extend far beyond the boundarjes of settlement. So that labour

1. In times of illness or other crisis neighbours will help each other without expectation of an equivalent return. But the practice (Euhar) occurs infrequently. 
gangs formed in hingung, for exomple, are recruited mainly from households in the settlement ond partly from adjacent households in Bharapo.

The restricted radius of recruitment also tends to exclude members of other costes from Limbu work gangs. Only a handful of households in Bharapa exchange labour with liagars and a few poor Brahmins living in an adjocent settlement, and a similar practice is followed by some households in Dorumba. Labour is never exchanged with wealthy Brohmins in the Cluster. This is mainly due to the reluctance of the latter, for reasons of prestige, to send members of their households to work on the fields cultivated by others.

The labour pool on which households can draw is limited not only by factors of settlement and neighbourhood, but by considerations of trinship as well. One brother tends not to participate in another's labour gang. The reason is seen by limbus as relating to the fact that male siblings inherit from a single source. In one instonce, relations between two brothers were strained to the point of a complete severance of day-to-day ties. In others, structural strains were expressed langely in avoidence of one another's work gangs. ihere relations anong brothers are amicable, 
exchanges of labour wil involve nembers of their households, but the brothers themselves will not join the gangs. This does not prevent them, however, from working together in the lobour gangs of third persons. Of 27 such gangs observed working on the fields of men with merried brothers in the Ciuster, only one gang contained a male sibling group.

Seventeen Limbu households do not partake of mutual labour exchanges because they cultivate insufficient lands to require help from other households. The work they hovo to offer, therefore, is for payment only. Along with 57 other households, which combine exchanges with labour for wages, they form a pool of labour for wealthy Brahmins within and surrounding the Cluster as well as for a number of Indreni Iimbus. The eight Iimbu households regularly hiring labour are compelied to do so because the hands they require to cultivate their lands are not obtainable through mutual exchanges alone. The labour gangs recruited by these households, then, are apt to contain both paid and exchange labour. But whereas the recruitment of the latter type is confined to neighbourhoods, agricultural labour for wages is sought from within a wider circumference. Fiesidents of hngbung, for example, who never exchange labour with Chitok limbus, do work for wages on the fields of the 
latter.

It is impossible to speak of a eree market for labour in the region of the Indreni settlements. Jimbus con earn more by working for Brohmins in settlements to the south of the Cluster than by labouring for Limbus or Brahmins in the Cluster. For hoe work the deily rate in the Cluster is $\mathrm{Rs} 0.80$, while Brahnins outside offer up to Rs 1.20. Similarly, a ploughmen receives Rs 1.60 if he works on Indreni fields, and up to Rs 2.40 if he ploughs for outside Brohmins. Ljmbus, of course, do work for the latter, but not at the expense of withdrawing their labour from the former. Here again, explanation must be sought in the multiplicity of ties within the Cluster binding labourers and those who hire them.

How important is agricultural labour for wages? It would be impossible to estimate the amount of income earmed by Iimbu households from this source. of 74 households engaged in casual labour of this sort, six rely only on this source to supplement income from fielcs they cultivate. Ihey earn on average of about Rs 250, but most other householas depend only perfunctorily on agricultural wage labour. This is because a number of other opportunities for eaming cash are available. Some of these, like agricultural labour, can 
be exploited within the Indreni settlements.

F'ishing provides four households with on average annual income of Rs 105. Only one man uses a net, while the rest must employ cruder techniques to make their catch. L series of stone dams are first erected, jutting out several feet from the river bank. A grass is then spread over the slowly moving pools created by the blockage and this has the effect of stunning the fish so that they can be caught by hand. $\hat{A}$ number of wicker baskets are also placed at the foot of the dams and some fish are cought in this way. The process is labourious but between October and Rarch an assiduous fishermon can trap up to ten pounds a week. These sell in the market and the Cluster for Rs 2 per pound.

Two households hove mondarin groves producing about 7500 fruit a year between them. The manderins are transported to sanisare, a market tow about 25 miles away in the Terai where they fetch more than double the local price. The two households earn an avergge of $\operatorname{Rs} 310$ smudily from this wource.

Tive Indreni household heads earn o regular income by performing ritual services in the cluster. A Iimbu ritual specialist (phedangma) discovers his 
powers through dreans on, as is more of ten the case, by becoming possessed. He then seeks the gruidence of a teacher from whon he learns the secrets of his calling. Households choose their phedangma on the bosis of utility. Some try and discard severol before finding one they believe to be efficacious. Others alternate between two or more phedengme. Kinship is not a serious consideration in the choice of a ritual specialist. The two most popular phedangms in the Cluster hove amone their clients representatives of all the main lineage groups. Nor is neighbourhood an important criterion of choice. Three phedangma have clients in three different settlements and a fourth in all four of the Indreni settlements.

Fewer than one third of alJ Limbu households ever utilize the services of a Brahmin priest. For those that do - and they are mostly the better-off households - the occasion is on annual satya Narayan ritual. Limbus choose this particuler rite because for one thing it is brief and relatively inexpensive and for another, because Satya Narayan is the Hindu deity which is believed more than others to affect the fortunes of a household. But the employment of Brahmins stops there. 
It is the phedangras whom oll iimbus exploy to officiate at the importent rites de passoge at the time of birth, morriage and death. A phedengme is also required to conduct the worship of domestic deities and in addition, is one of a veriety of specialists who may be called to treat illness. Since the household propitiates its deities on an average of three times yearly, the phedengima's minimum annuel income from this source can be estimated. The fee generally paid for the perfornance of a ritual. is Rs 1.60 , a pint of liquor ( $R_{S}$ 1.) and enough rice for a meal ( $R_{s} 0.60$ ). The phedangme can thus expect to earn a minimum of approximately $\mathrm{Rs}$ 10. per client per year. One specialist, with twenty--seven household clients, relies only on his income from this source to supplement his meagre production from a household plot. The most popular specialist, with thirty-three clients, combines his work as phedangma with agriculturol labour. Lt a minimel estimate, then, eighty households pay $\mathrm{ks} 800$ annually for ritual services, which monies are divided among five phedangmo.

Four extrenely poor households earn small incomes by providing moro affluent houscholds with 'domestic service'. The most common proctice is for 
young boys from poor fanilyes to live in wealthier homes. They are treated like nembers of the new household and, as with other nembers, their labour is at the disposal of the household head. They are referred to as herdboys (rothalo) although they work in the fields as well as tend cattle. For these services they are fed and clothed, and paid an annual salary of from Rs 15 - 50. The relationship seldom persists over a lengthy period, the herdboys generally returning to their own homes after a year or two. Three households earned on income of $R_{S} 100$ from providing this kind of service. In another instance, the wife of a poor Chitok man did domestic chores for a wealthy neighbour whose own wife was chronically ill. The arrangement enabled the former to spend only a few hours each day at ber ohores, returning daily to her own home. For her assistance she was paid about Rs 40 over the year.

Finally, one household earns $\mathrm{Rs} 110$ a year from the sale of clarified butter to a Jaisi in the area who markets it in Ilam. The son of another household head, although only a fifth former himself, eams Rs 420 as a teocher in the local primary school. 
Commerclel Sources: outsjde the Oluster

Since the turn of the century, and especially during the past two decades, Indreni limbus have been turning to incone sources outside the Cluster. These opportunities come under three main headings: government service; portering and petty trading; and casual labour.

The Government has been a potential employer since the establishment of an administration in Ilam. Indreni Iimbus have been employed for years as minor functionaries in Government offices in the Bazaar. Three household heads spent a total of thirty-six years in the local militia, while three others served for two to four years in regular army units stationed in Ilam. At present two household heads are in Government service. One is a policemen, eaming Rs 740 per annum while another is in the militia with a salary of Rs 580. The former is able to return home regularly, but the latter, since he is posted to a border station about fifteen miles away, cen visit only during his leaves.

Opportunities for petty trading and portering have grown apace with the commercial development of Ilarn Bezoar. At the turn of the contury, the Bazaar 
contained only half a dozen shops, enough to cater for the few resident Government employees as well as those visiting the town on market day. By 1964 there were ninety shops and a resident population of approxinately $500{ }^{1}$. The size of the merket, too, has grown. On any Thursdey upwerds of 2000 inhabitants of the surrounding area make their way to the Bozasr, and provide a substential buying public for the permanent shopkeepers and petty traders.

Women of the Indreni settlements distill liquor (raksi) from millet and sell this to 'tea' stall owners in Ilem Bazear who retail it on market day. Some of the women also sell liquor on the main road through the Cluster to persons going to or returning from the market. I'hree households situated beside the main road offer hospitality to trading expeditions, providing cooking utensils and sleeping arrangements free of charge, and profiting from sales of liquor. Despite o Government ban - never enforced - on the sale of spirits without a licence, thirty-seven households earn an annual profit of about Rs 6840 from this trade. It

1. Under ranchayat regulations, to qualify as a 'town' there must be a population of 10,000. Ilam Bazaar has thus absorbed a number of surrounding settlements to nake up the difference. 
is the most importent commerciol source of income earned locally by Indreni Limbus.

Indreni women also regularly bring for sale in the market a kind of yeast loaf (marca) used in the preparation of liquor. From this trade, eleven households clear Rs 2195 annually. Another household head has a permanent stall set up each Thursday in an area of shops at an important crossroads between the CIuster and Ilam Bazar. From the traffic generated by market day he is able to earn a profit of Rs 160 over the year from the sale of meat, beer and liquor.

Since the revolution of 1951, Ilam Bazaar has enjoyed an unprecedented growth. The expension of existing and establishment of new Govemment services (including two secondary schools and a college) and a growing population have led to a surge of building activity. Since road communications in the district, as in most hilly regions of Nepal, are extremely primitive, goods can only be tronsported by horse caravans, or on the backs of men. For residents of the Indreni settlements, this has meant new opportunities to porter the increasing volume of raw materials required for building. Chief among these is wood.

Over the past five years alone the amount of wood caming into the Bazar has increased fourfold. During 
the dry season from November to iay, the porters carry planks from the forests south of Ilan Bazaar, where the wood is cut and trimmed, to the district capital. Indreni men usually work in teams, contracting to carry up to 1000' at an average rate of Rs 192. Sone men carry six days a week throughout the season, others porter only occasionally, as their cash needs demand or strength allows. The twenty households engaged in portering earned a total of $R s 5300$ in $1964-65$. Another three household heads, who are skilled sawyers, contracted to cut some of the timber corried by the porters. They brought home a profit of Rs 350 for a month's work.

Portering wood is confined to households in the two southernmost Indreni settlements, ingbung and Bharapa. This is portly because these settlements are closest to the forests. By leaving their homes in the early morning, the porters are able to return, after carrying a timber load, the same evening. But the confinement of this enterprise to households from one section of the Cluster also attests to the strength of neighbourhood ties. Porters like to travel in company with others, and neighbours are preferred company. Tin sheets for roofing, water pipes, cement, kerosene - indeed a whole range of capital and consumer 
goods needed to sustain the Bazear's growth - are also cerried by porters. For these items, however, the men must go to Sanisare, a morket town in the Teroi to the south. But unless they can carry a load both ways, the journey is not worthwhile. Ponters therefore tronsport mandarins to Sanisare from groves north of the Indreni Cluster. Some accept a fixed rate - about Rs 3.20 per 100 - to porter the fruit. Others assume the role of middlemen. They purchase the mandarins from the orchard owners and trensport then to Sanisare, where they can fetch from two to three times the hill price. The capital required is small and the profits earned are re-invested in consumer and capital goods needed in Ilam Bazar. The profits from these trading and portering ventures, which take up to five days, can be substantial. The eight households - ggain all from Bharopa and ringbung - engeged in this enterprise earn about Rs 900, most of it during the six week mandarin season.

Another source of income is casual labour in the Terej or in bordering areas of Indis. The agri-cultural lull around January and February, before the maize is plonted, finds a number of Indreni residents working for wages out of the district. During the 
winter of 1964-65 eight household heads spent from two to six weelis employed as unskilled labourers on a variety of building projects in the Teroi and Darjeeling district. The eight brought home a total of Rs 1150 . The head of another household is a skilled carpenter and relies regularly on work in the Tersi - and, when he can find it, in and around the Cluster. His annual earnings amount to approximately $R_{S} 300$.

\section{Military Eervice}

The most Iucrative source of income for timbu households is service in foreign armies. The history of militory service by Indreni men roes back to the establishment, in the first decade of this century, of two Gurkha regiments composed exclusively of Rais and Limbus ${ }^{1}$. Prior to this time nembers of the two groups had been admitted to vorious para-military forces stationed in Burma and Assam. But their service in the Gurkhas, created a century and a half ago, had been limited. The Iimbus, particularly, were considered to be inferior soldiers, opparently having acquired a reputation for lack of discipline ${ }^{2}$. Following the

1. To avoid confusion with previous references to 'Gorkha', I spell the term for servicemen as 'Gurkha'. 2. Jackson, 1940, p. 434. 
creation of the two eastern regiments, however, an averoge of 221 limbus were recruited annually from east Nepal. Ls the prejudice agajnst them gradually receded, their numbers rose. During the next decade an average of 283 were recruited each year?.

The acceptance of Iimbus into the Gurkha forces coincided with the growth of large-scale mortgaging of kipat lands in the Oluster. The limbus were compelied to find other sources of income. Possibilities were limited, since IIam Bazaar was still in its infancy and could not offer opportunities for trading and portering described above. After the first two Indreni men were enlisted in the Gurkhas prior to the t'irst World var, militery service was seen to be a viable means of earning income lost as a result of land mortgaging. During the War, when recruiting was intensified and standards of induction considerably relaxed, eleven Indreni men were accepted in the army. Since then, a substantial proportion of the Cluster's mele inhabi-tants has served in the Gurkhas ${ }^{2}$.

1. Vansittart, $1915, \mathrm{p} .8$.

2. By and large, Brahmins do not serve in the Gurkha regiments; nor are they encouraged to do so. Although members of other castes, such as liagors, are recruited, none resident in the Indreni cluster is in the army. 
The resson most often cited for joining the amy is the need to eam money becouse of economic hardship (dulke). Iinked to the financial inducenents is the respect accorded a returning soldier, especially one who manages to rise above the ranks. Prospective volunteers speek of 'making a nome' (nom komaunu), and each of the recruiting forces is graded according as how it is believed to allow for promotion'. Young men also admit to an urge to travel and, occesionally, to the fact that personol squabbles within the household may drive them away from the CIuster. Still, economic motives must be seen to underlie the widespread attochment to military service. Despite the fact that Ilam district has never been a prime source of recruits ${ }^{2}$, $43.8 \%$ of all living Inareni Limbu males aged eighteen or over either have served or are at present serving in the ermy. Those in the forces at present constitute 11.5\% of the adult male population.

1. In 1947, the Gurkho regiments were divided between the Indian and British amies, each of which now recruits separately. There is also the Hssam Rifles, whose recruiting efforts are closely coordinated with those of the Indian Gurkhas. For convenience I includo the Assarn Rifles with the Gurkhas.

2. Apparently, it still is not. Out of approximately 180 Limbus recruited in 1964 at Dharen, the British recruiting depot for esstem regiments, only 16 were from Ilam district. 
As might be expected, the more dopressed sections of the commity turn most frequently to Gurlkha service. Members of groups without ownership rights to kipat in the Cluster are a case in point. In Chapter II it was show how the accommodation of 'outsiders' by Indreni kipat-owners varied in accordance with the availability of land. Once the shortage had reached a critical stage, affinal or cognatic kinsmen who settled in the Cluster could not expect to receive kipot grants. At best, they were able to occupy small plots of kipat belonging to theix hosts or, as in some instances, to purchase some raikor land. But these lands were invariably insufficient to support their descendants. Whereas impoverished Iimbus with owership rights to kipat had first refusal on tenancy offers, in addition to rights of berd, non-lripet owners could claim no such prerogatives. In consequence, males of the first succeeding generation of outsiders tended to join the army. A few examples will illustrate the pattern which repeated itself almost without exception.

A man fron the district of Panchthar settled uxorilocally in the Cluster after marrying the sister of a Chongbung man. During his lifetime he cultivated a small piece of kipat land taken under mortgage 
from his father-in-low. The land was not sufficient to support two aditional families which his sons would soon create. On reaching adulthood, both joined the army.

In a replica of this instance, all four sons of a man who married the daughter of the Niembeke Subba joined the army.

Sometines, the process is delayed a generation. The first Indreni Angu settled in tie Cluster after marrying a Chongbung woman. Since he was a Government servant posted to Ilan, he had an income with which he was able to purchase some raikar land in Bharapa. There wes sufficient land to divide among his three sons, although one fell on bad times and enlisted in the Gurkhos. When the lands were divided again among the grandsons, the estates proved to be inadequate. Four of his six grandsons served in the Gurkhas.

A similar train of events follows on those who are raised in the Cluster through matrilateral ties. When a Kambo absconded with the wife of another man, he also brought along the woman's son from her first marriage. When the boy grew up he chose to remain in the Cluster rather than return to where his kipat rights lay. To accumulate the capital necessary to obtain land 
he joined the Gurkhas.

The army is still the most important income source for Limbus without ownership rights to kipot land. fix of the twelve men in the army at present are members of non-kipat-owning households. They account for $42.8 \%$ of Iimbu males without kipat between the ages 18 - 40 years. The six who own kipat, on the other hand, represent just over 11\% of kipat-owning males in the same age bracket.

Military service, of course, is not entirely a matter of the individual's own choosing. Firstly, acceptance into the army depends on physical and intellectual criteria over which the volunteer has no control. Secondly, his chences vary in accordance with the annual quotas accepted by the various forces. Thousands of hopeful candidates are turned away each yeax at the recruiting camps or by special recruiting agents in the hills. But once accepted into the army, a number of factors may still militate against long service. During both World Vars, for example, standards were lowered to allow for maximum enlistment. But at the conclusion of hostilities, most of the wartime recruits were dischorged. Sixteen of the thirty Indreni men who have completed their service were wartime 
volunteers who spent an average of 5.4 years in the military. Most were released at the end of their service, others chose not to re-enlist. Some, like four Indreni nen who were in the Gurkhas between the Vars came home on leave and never returned.

The need to return home to menage an estate is a common reason for the failure of Indreni men to complete the minimum service required for a pension?. Those who are away rely on fathers and brothers to protect their interests during their absence. The death of such a person, then, night require a man to leave the service. Quarrels over division of property are also causes of premature resignation from the army. But personal inability to adjust to army life also counts as an importont reason for leaving. The early years are the most difficult, and desertions or resignations occur most frequently in the formative years. None of the Indreni servicemen, however, left the army after serving eight years without first qualifying for a pension. The investment of so much time is thought to be worthwhile only if it leads to a pension, so that during the latter half of the period of service, the

1. The period of service required to receive a pension varies. By end large, to receive o private's pension, 15 years of service is mandetory. 
pressures of obligations at home are resisted more assiduously than during the first years.

Wight of the thirty ex-servicemen are receiving long service pensions totalling Rs 6110 per year. Two others, who were discharged on medical grounds, are paid Rs 1250. Three households receive pensions paid to immedjate descendants of servicemen killed in action. These amount to Rs 710 each year. The total income from pensions therefore amounts to Rs 8070 each year.

Service salaries account for a substantial proportion of current income. Twelve soldiers earn a total of Rs 14,250 annually in pay. Based on past remittances and on estimates of average savings, it can be ossumed that about $60 \%$ of a soldier's pay eventually reaches the Indreni settlements. This would mean a net income of Rs 8550 from army service. Not all these monies enter the CIuster on a regular basis. No arrangements exist for the trensfer of funds to homes in the hills. Remittances can be sent to the recruiting centres and fetched from there, much as pensions are collected. Servicemen returning on lesve often bring monies for the families of soldiers with whon they are serving.

There is little pressure on unmarried sons or 
brothers to send money. Lven when they return on leave they are not expected to hand over all their savings to the household head. An unmarried soldier who had saved close to Rs 2000 brought home only Rs 500 on his first leave. Even though the serviceman who is not formally separated is a part of his father's or brother's household, and recognizes his membership by token remittances, his position is somewhat ambiguous. Throughout his army career he enjoys a special status, not entirely consistent with membership of a household. This is best understood by considering the typical sequence of goals to which his ermy savings are applied.

The young man who enters the army as $\theta$ bachelor first of all saves for his marriage. Following his marriage, for as long as he remains part of a joint type household, he contributes to it a part of his savings, but holds back the greater proportion for the time he decides to establish a separate household. This usually comes several years later when he has savec enouch for a small estate. Occasionally, he puts off separation until completion of his service. One Gurkha soldier who was pensioned off in late 1963 separated from his fother's household three months later. 
He used monies accumulated over a number of years to obtain land, build a house, purchase cattle, and so on. These monies, strictly speaking, should have been turned over to his father while he was a part of his father's household. The extent of remittances will depend somewhat on the size of the soldier's nuclear family. As its numbers grow the greater the obligation to aid in their support. There is also the matter of residence. If they are part of his father's or brother's household, or remain in the wife's natal settlement as part of his father-in-law's household the serviceman is expected to contribute accordingly. On the other hand, now that facilities exist for wives to join their husbands for at least part of the period of service, some soldiers do bring their families with them, and correspondingly reduce their remittances. Clearly, the serviceman who remains part of a joint type household retains a special status unlike that of other household members. He tends to act as if he were the head of an independent household even if he is in fact nominally part of a larger unit. Just as clearly, members of the latter have little power to coerce him into placing his entire eamings at their disposal. 
When a soldier becomes the head of a household, the siturtion changes drastically. He assumes not only the responsibility for his own wife and children, but for younger siblings as well. Here, too, there is discernible a set pattern of priorities in the expenditure of monies earned from army service. Firstly, food shortages must be made up and recurrent or contingent debts met. For exanple, in 1965 a soldier returned on leave with Rs 1500 designated for the marriage of a younger brother. Following his own marriage, his savings had been deployed towards the repayment of interest-bearing loans and the purchase of food. Then his brother approached the age of marriage, monies were set aside to meet these costs. Investment in land generally occurs only after these initial obligations are met. For this reason, short term service seldom has any real effect on the overalil economic position of a household. It is only the cumulative effect of long service which allows for an alleviation of the poverty which may have driven the limbu to enlist in the first place. Those who remain in the army for long periods stand a better chance of proinotion with its attendant pay increases, and of course derive the financial security provided by a lifelong pension. 
Iong service provides the opportunities to accumulate savings which cen be invested in land. The procedure described in Chapter $V$ is repeated, but bidding for kipat ore no longer only members of other castes, but limbus with funds eamed by military service. The following examples will illustrete the process.

a. Between 1948 - 1961 a Limbu of Chitols without ownership rights to kipat took under mortgage four different kipat fields, now valued at ks 4560. ilwo fields had previously been pledged to Brahmins living outside the Cluster, one field to a Blacksmith of Chitok, and the fourth to a limbu widow Iiving alone in Bharapa. The Chitok man was only able to becone a landholaer because an annual pension of Rs 425 was being paid to his mother following her husband's death in Burma during the Second world War.

b. In 1962, a Chongbung of Bharapa with eight years of service in the army retumed on leave from the Assam Rifles with $R_{s} 960$ which he had saved to repay a mortgage on a paddy field. The land, his own, had been pledged. by his grendfather to the father of a Newar resident in a neighbouring settlenent. The members of his household, which incluced his mother, brother and sister repossessed the field and resumed its cultivation, 
which added 400 units to their peddy incoine.

c. In 1964, a non-kipat-owning resident of Bharapa, in his tenth year with the Gurkshas, cane home on leave and took under mortgage a paddy field which had previously been pleded to and worked by a Brahmin from outside the Cluster. The mortgage capital was $R$ s 1280 which he had saved during the last iwo years. Since his household contsined only his wife ond a young daughter, he gove the lond to his mother's brother on tenancy for on annual rent of 190 units.

d. In Angu of Bharapa, without ownership rights to kipat recently completed fifteen years of service in the army. With Rs 3200 of his savings over the last three years, he paid berd to the kipot owner (like those in the first and third cases above) and took under mortgage a field producing 1200 units of paddy. The field had previously been pledged to a Brahmin who had cultivated it himself.

These cases have two things in comrion. In the first place they involve monies eamed from amy service being used to gain, or regain, landholding rights to kipat. Secondly, virtually oll the lancls repossessed or token under mortgage with these funds had previously been 
pleded to members of other cestes, mostly to Brahmins resident outsicle the Cluster. This is of course inevitable since these other castes hove been the main source of mortgage credit for the Limbus. What is significant is that only during the past twenty years or so service in the Gurkhas has made it possible for Limbus to obtain and regain landholding rights to kipat which for decades has been in the hands of these other castes. From the point of view of the owners of kipot, the inflow of monies earned in military service provides added opportunities for them to obtain bard in the process of transferring landholding rights. However, it has already been suggested that the freedom to manipulate rights of land ownership cen be restricted by the pottern of multiplex ties. This would certainly apply to relations between Ijimbus - more especially, between neighbours. A dispute which arose following the transfer of a kipot mortgage from one Iimbu to an ex-soldier neighbour suggests the kind of reaction forthcoming upon an attempt to disregard these ties.

In 1960 Kabir Hang borrowed Rs 600 from his classificatory brother's son Ram. Kabir Hang in return gave the latter a small plot of unirrigated land to cultivate under possessory mortgage until the loan could be repsid. The plot adjoined one of Ram's own fields 
near his house so he could cultivete the entire stretch of land at one time. In 1964, rul Bohadus, an Angu, and a recently retired soldier (see above, case a.) offered Kabir Hing the mortgoge price and an additional increment (bard) of Rs 350. The landholding rights to the plot which Ram had been cultivating were then transferred. The maize was sown by Kul Bahodur in Merch but Ram said nothing at the time. In August, shortly after Kul Bahadur had transplanted his millet seedlings, Ram confronted K̈abir Hang in a rage and demended to know why the latter hod allowed Kul Bahadur to plant his millet on Ram's land. \& boundary dispute then ensued although the total amount in question was perhaps thirty square feet. The matter was composed by a number of onlookers who had heard the shouts, the most instrumental. being a Newar ritual friend (mit) of Lul Bahadur, who happened to be passing by. Kul Bahodur dia not appear himself. The disputed area wels divided in equal parts. When I asked Ram about the dispute, he did not refer to the disagreement over the boundary, but instead was vexed about the fact that Kul Bohadur had offered Kabir Fiong bard. Fe was equally annoyed with Kabir Hang for taking the land away from a neighbour and an agnate and giving it to Kul Bahadur, an affine who has no kipet (but who is also $\theta$ neighbour). Ram then went on 
to say how being in Malaye (where o lorge contingent of British Gurkhas are strationed) eno eaming a lot of money had gone to hul Bahadur's head. He cited a number of exemples of the latter's impertinent and haughty behavior. What had begun os a boundery dispute was in fact a gnievance oven having lost landholding rights to a plot of land. It was also a generol statenent about the fact that servicemen are at a distinct advantage in bidding for lands pledged to others. Ram was giving vent to bis anger, and. since kul Bahadur is not only an ex-servicemen but a member of a group without rights to kipat as well, he chose to attack along the lines of an olready existing structurel cleavage.

Such o dispute is atypical insorar as the great majority of londs taken under mortgege by soldiers and pensioners were previously pleaged not to limbus, but to Brahmins and other castes. I did not learn of any instance where a soldier attempted to bic for lands held by Brahmins resident in the Oluster. The people most affected by the srowth of this formideble source of income have been those lendholders of Brohuin and other castes resident outside the Cluster.

How much of this movement of kipot lands away from members of other castes and into Ijmbu hands can be ottributed to Gurkha service? In Chapter $V$ it was shown 
that $21.3 \%$ of all mortgaged lipot lands have been taken up by Jimbus resident in the Cluster. Of this amount, 14.8\% has been pledsed to ten ex-amy pensioners. This represents an investment of $R S 37,800$ during the past fifteen years and a transfer of just under 14,000 units to Iimbu lendholders and away from those of other castes. These figures do not represent the entire picture since they exclude monies expended by kipatowning soldiers and pensioners to repry mortgages and repossess their own lands. Thus, six of the seven Iimbu households which today enjoy the unimpeded usufruct of their own kipat lands can attribute their position to monies earned from service in the Gurkhas ${ }^{1}$. In adition, wen serving in the army at present have invested close to Rs 8000 to take over 1000 units of kipat land under mortgoge (1.2\% of mortgaged kipat) and purchase 500 units of reikar land.

In some measure, this tendency for funds earned. in the aring to be reinvested in lend is to be explained by reference to altemative opportunities. There is no industry in Ilem which might attrect investment sunds. Nox is there any other outlet which could offer the prestige and security that land provides. The only 
likely alternative is the provision of interest bearing loans. This is in fact exploited and four pensioners between them provide Rs 2000 in loans, equal to $48 \%$ of the credit provided by all Limbus in the Cluster.

But lack of alternatives is only part of the explanation. The system of kipat tenure, which ensures that rights to land can never be alienated, provides a strong incentive for men serving in the ormy to maintain their ties to home and land. For as long as they are away, ownership rights remain intact. The system, moreover, benefits not only those who ow kipat. The fact that kipat is inalienable means that limbus without ownership rights themselves, but with sufficient funds, can always obtain lands through mortgage, by employing their ties of kinship and neighbourhood to keep open this avenue of investment, and of course by their ability to provide bard to the owners.

The effect of the inflow of pensions and salaries, therefore, has been to improve the agricultural economy of those households benefitting from external income sources. It is worth noting that four of the seven Iimbu bouseholds with the largest income from agriculture are headed by ex-servicemen receiving the largest pensions in the Cluster. 
Does income from local sources provice an investment fund for land in the same way os do pensions and army salaries? As I hove show, opportunities for earning cosh have increased substantially over the past fifty years in the areas to the south of the Cluster. Sixty-five households regularly engage in a variety of commercial activities. The available opportunities are not, by and large, mutually exclusive. About half of all Iimbu households earn incoine from more than one of these sources. Even a household whose head is in the army can add to its revenue by petty trading, since it is engaged in mainly by women.

Earnings from commercial activities in the area, however, serve only to maintain the status quo. Households which do not have sufficient agricultural production to meet their veried requirements, recurrent and contingent, rely on alternatives available locally to fill the gap. Others with adequate agricultural resources sustain their viable economic positions by availing themselves of the opportunities for eaming extra cain. In general, the inflow of cash from sources around the Cluster enables Limbu peasants to hold the economic line. But these injections of cash, unlike the monies eamed by military service, are not adequate to bring about any lasting improvement in the overall 
economic position of the Iimbu households which exploit them.

Nevertheless, certain advantages are seen to attach to economic activities in the area. Such activities, unlike army service, do not require a man to be away from his home and family for long periods at a time. Certain kinds of trading are confined to weekly market days. Others, like wood portering require the adoption of a commuter schedule. Dome long distance portering involves absences of only a few deys at a time. Moreover, the commercial activities can be taken advantage of without neglecting the demands of agriculture, so that a household con manage its tasks in both sectors with a minimum of conflict.

There is an indication that as local opportunities for earning cash have expanded, fever Indreni limbus are turning to military service. This is especially noticeable among those limbus who have ownership rights to kipat land. Whereas $71.8 \%$ of living males over 40 years of age who own kipat served in the army, only $14.8 \%$ of those between 18 - 40 years have served or are doing so at present. The corresponding figures for limbus without kipat are $75 \%$ and $50 \%$, which is to be expected for reasons already cited. The figures are undoubtedly biased since the over-40 category subs!mes those who 
joined during the two world wers when recruiting was less selective. Still, the trend awey from military service appears evicent, when it is noted that seven of the eight kipat-owning servicemen in the lower age category are resident in Dorumba and Chitok, the northernmost Indreni settlements, where local cash earning opportunities outside the Cluster are of only incidental importance. None lives in Angbung, and only one in Bharapa, from which settlements the local sources of income are most fully exploited.

How do earnings from all other sources compare with income from subsistence agriculture? Translating the net income from agriculture into monotary terms at the current rate of $R s$ 1,20 per unit of paddy and maize, and Rs 0.80 per unit of millet, the value of net agricultural income is $R_{s} 99,420$. Dernings from commercial sources are detailed in Table 32. The number of households engeged in each activity appears in the column on the left. 


\section{TABIIE 32 \\ Eamings from comerciel sources 1}

Local Sources: within Cluster ${ }^{2}$ ijo.of Eouseholds Annual Income

Domestic service

Fishing

Sales of mandarins, butter

Ritual services

Teaching

Iocal Sources: outside Cluster

Government service

Sale of liquor in market

Trade in liquor, meat

Sale of yeast bread in market

Portering wood, wood-cutting

Trading, portering mandarins, etc.

Labour in Terai, India

External Sources

Pensions

Army salaries, remittances 3
4
3
3
5
1

Rs $\begin{array}{r}140 \\ 420 \\ 730 \\ 800 \\ 420 \\ \hline 2510\end{array}$
2
39
1
11
23
8
9
1320

5950 160 3085 5650 900 1100 $\overline{18165}$

\section{3 \\ 12}

8070

8550

16620

Total Rs 32295

The above rable shows that commercial sources

provide an income equal to approximately $38 \%$ of net agricultural income. Table 33 gives the proportions for

1. It is necessary to stress that some of these figures are only estimates.

2. Income from agricultural labour proved impossible to estimate and is omitted here. It should also be remembered that bard provides another source of unearned income.

3. As I explained, remittances from servicemen are not made regularly or in full. The figures, then, are for potential, not actual, income. 
individual Iimbu households. The breakdown is given by settlement, since proximity to local sources of income is a determining factor in thejr utilization.

\section{TriBIJ 33}

Income from comnercial sources

(expressed as a percentage of agricultural income)

Income Percentage

None

$1-49 \%$

$50-99 \%$

$100 \%$ or over
Number of Households Angbung Bharapa Chitok Dorumba Total

Eleven households eam no income from commercial sources. Most of these households (eight) are in the two settlements situated farthest from Ilam Bazar. Seventyfour households, therefore, have some income from commercial sources. The majority ( 43 households) earn funds anounting to less than half their income from agriculture, while onother eleven households have commercial incomes which amount to between $50-99 \%$ of their earnings from agriculture. Approximately one quarter of Indreni households earn more from commercial then from agricultural sources. Again, it is worth noting thet seventeen of the twenty-one households in this category are resident in ringung and Bharapa. Four 
of the eight households in Bucropo are in the cotegory because of remittances from nen presently serving in the Gurkhas. But the four remainine households, like the nine in Ingbung, earn their commercial income from locel sources. Two Chitok and Dorumbo households are in this category because of pension earnings, while the other two have local sources of commercial income.

The growing comitment to commercial sources of income can be seen to affect social relationships within the Indreni settlements in two ways. In the first place, the agricultural system no longer represents the sole means of livelihood for the Iimbus. To be sure, the origin of, and, indeed, the motjve sustaining their reliance on commercial activities turns on economic necessity. But as opportunities for earning wealth outside the agricultural system hove expanded, the household continuously reappraises its om alternatives and makes new choices based on economic selfinterest. The effect, evidenced in the fact that $25 \%$ of all limbu households earn more from commercial than 
from agricultural activities, hes been to confer on the Limbu household a greater freedom to opt out of relationships of dependence on those who tend to dominate access to the lond.

In the second place, that wealth eamed outside the Cluster which is reinvested in land redounds to the benefit of the Iimbus and, conversely, to the detriment of the chief landholding castes. Thus, Limbu exploitation of commercial income sources poses a constant threat to the economic ascendance of these other castes. The kipat system of land tenure, by guaranteeing Limbu owhership rights in perpetuity, keeps ajar the portal of economic change. So that while agriculture is less important in the overall economy of the Limbus, land is still the basis of Iimbu security, and the Cluster still the focus of their social ties. 


\section{CHAPIER VII}

\section{POLITICS II THE SEITLEHANTS}

In this and the following chapter I consider the political configuration in the Indreni settlements. Any description of political life in the Cluster must take into account the factor of Government presence. Since the absorption of Ilam into a national polity in 1774, Kathmandu, first through the militia, and later through the civil administration, hos exercised a monopoly of coercive force. Settlements, however remote, heve been encompassea within a wider political system.

The influence of the Centre is evident at the lowest political levels. Government-approved headmen exercise leadership roles, the definition and scope of which are largely delineated by the netional authorities. The first task, then, is to describe the role of Subba. This is done by outlining the bierarchicel framework of leadership which existed until the liattes part of the 19th century, at which time the hierarchy collapsed as a result oi both Government policy end changes in the pattern of londholding described esrlier. I then consider contemporary contexts of leadership and relate these particularly to the settlement of disputes in which 
Indreni Iimbus are involved. The emengence of new leaders who derive power not from traditional ascriptive criteria but from wealth and stotus eamed through militany service is noted. Finelly, the nature and composition of factions formed around two Brahmin residents in the Cluster are described. The question which underlies the latter analysis asks whether or not factional strife mitigates the freedom of alignment maintained by Iimbu households in other contexts already noted?

\section{The Ieadership Hierarchy}

In Chopter III I pointed out how Subbas gave grants of kipat land to non-Limbus immigrating into Iimbuan from the west of Nepal. The recipients of these grents were appointed by the jubbas as political underlings (Theri) ${ }^{1}$. These latter, were, in turn, encouraged to settle their own Holdings by offering land to the immigrents who followed. In the region of the Indreni Cluster, for example, the extent of land grents was considereble. The Chongbung and Nembeke Subbas between then granted fourty-four Holdings out of

1. Although there would seen to be no logicol reason why Limbus covld not be mede Theris, in ract this did not happen. All 'iharis are non-Iimbus. 
which further ellotnents were wade by the recipient Tharis 1 . The Holdings encompassed an area of some twelve square miles and included, by the time of the last revenue settlement in Ilam in 1936, approximately 1000 registered households.

Thus, a political hierarchy was created which mirrored the hierarchy of land Holdings. This was symbolised in the annual payments of tribute made by dependents (reiti) to their rharis, and by the latter to his Subba. During the festival of Dasein Tharis were obliged to bring gifts of parched rice, curd and fruit, and in return received a tika from their subbas. sgain, at the beginning of the liepali year, during the Iunar monti of Bajsakh (fipril-May), Tharis were constrained to bring further offerings of cash (Rs I) as well as clarified butter and cura, at which time they would request the renewal of their land grants for the coming year ${ }^{2}$. Theris were also expected to provide five days of unpaid labour or their equivalent in cash. This was

1. I was unable to ascertain the exact number of grants made by the Kembo Subbas, though they were probably fewer then either the Nembeke or the Chongbung grants.

2. It is unlikely, however, that subbas could evict their Theris without sufficient cause. See below. 
usually obtained from anong their ow dependents, who owed their Thari a similar tribute. The Limbu dependents of the Subbas, most of whom were his lineage mates, offered similor quantities of tribute. The Subbas also had the right to demand a percentage of the price of land sold by those settled on the Holdings he had granted. The fee usually amounted to about 10\% of the sale price, and was shared with the Thari concerned. Chief among the duties of the Subbas was taxcollection. This role placed him in a position from which certain economic adventages could be derived. Due largely to administrative problems in the far corners of the country, a contractual system of tax-collection was established in Iimbuan. Unoer this systern the amount of tax due was deternined during the course of a periodic revenue settlement. Moreover, Limbus were taxed not on land holdings but on the besis of a flat rate per kjpat-owing household. Although new households established between settlements were not liable for tax, Subbas were prone to collect taxes from these unregistered households and appropriote the revenue for themselves. The use of both Nepali and Indian currency in Ilom also enabled some subbas to assess the taxes in Indian currency and pay the revenue in Kepali coinage, 
thereby pocketing the difference in exuirange.

Another feature of the tax-collection system accrued to the advantage of the Subbas. Once registered, a Iimbu household was liable to the tax fixed at the time of the settlement. The tax was payable even if the kipat-owner died wi.thout heirs or emigrated. In such circumstances, if no other co-heir came forward to assume the liability of the vacant homestord, the obligation fell on the Subba. But the law, by obligating the Subba to pay taxes for lands vacated by his lineage mates, also recognized his right to re-allocate or keep for himself such vacated lands. These rights enabled the Subba to accumulate more lands than his lineage agnates. In rable 34 landownership by the Subbas is contrasted with the average landownership of households in his lineage - taken as a basic index of $100^{1}$.

1. Chongbung Iineages (I) and (2) pay taxes to the same Subba. Phatras, Syelings and Kambo Iineage (2) are omitted because in the first two cases they pay taxes to Chongbung Subbas while in the latter instance, there are only two households in the lineage. 
TABTI 3 and by Sub

Owmershis of kipa land by Subbes

Iineage

Chongbung Iineage

Kambo Iineage

Nembeke
Ownership of Itand by Subba*

( 5$)$
270.0

298.9

378.1

239.0

174.0

435.1

213.4

* The average landownership per lineage household is taken as index 100 in each case.

The differences between the amount of land owned by the Subbas and the average for households in their lineages are evident in the above Table. These figures, of course, refer to present-day ownership and do not necessarily reflect with accuracy the ownership ratios almost a century ago, since they take no account of inheritance patterns. But the trend indicated by the figures seems more than coincidental. Moreover, it is likely that the differences in landownership between headman and dependent arose jefore the turn of the century, since after that time land shortages encouraged co-heirs to press strongly their claims to vacated lands so that fewer lands accrued to the subbas unless they were related as co-heirs themselves. Tharis collected taxes from the dependents on 
their own Holdings and passed these on to the Subbas for submission to the land revenue office in Ilam Bazarr. If the Tharis attempted or, indeed, were implicated in attempts by their dependents to avoid taxes, the Subbas were entitled by the Government to 'fine (the Thari) one year's production and eat (i.e. keep) the fine.' In cases of persistent attempts to avoid tax obligations, a Thari could be dismissed by a Subba, acting in council with other Iimbu headmen ${ }^{1}$. By and large, however, as long as the Tharis submitted their taxes, behaved fairly to their dependents, and respected their Subbas, they enjoyed security of tenure on their Holdings. The Subbas could not arbitrarily evict either the Tharis or their dependents once they had been granted land.

The Subbas were the main channels of Government control in the settlements. A judicial council of Subbas (omal) acted as a court of original jurisdiction, with rights to hear cases of a civil nature involving damages not exceeding Rs 100, and with authority to impose fines of up to Rs $25^{2}$. Their responsibility for the

1. Order regarding failure to register lands and homesteads in Far Kirat, 1868.

2. The amal was not authorised to hear certain kinds of cases, called 'panchkhat': broadly speaking, those relating to caste or offences punishable by death or life imprisonment. (See Regmi, 1965, p. 1.18). 
mointenance of low and order extended even beyond the boundaries of their Foldings. when grented thein titles, Subbos were instructed to 'arrest any person who crosses the border (into Ilam) without our (Governmental) permission.'

Subbas were also held accountable for the maintenance of the main roads through their territory and all dependents were required to contribute labour, usually after the monsoons, to keep the roads in good repain. They recruited the porters required by the administration for the transport of essential foods and other materials. The Subbos were the earliest foresters and their pernission had to be requested before anyone in the orea under their jurisdiction could cut down heavy timber. They rounded up buffeloes and goats from the herds of their dependents for the Dasein sacrifice at military headquarters in Ilam. Obligatory contributions were imposed on the population at the time of such special occasions as the marriage of a princess or a royal coronation, and the Subbas were charged with the responsibility for administering the 
collections ${ }^{1}$.

The first chink in the political hierarchy

which had evolved from the system of land grants appeared in 1886. In that year, the Government decreed that all Holdings granted to non-Jimbus out of kipat land could be converted to raikar tenure by the Tharis. In consequence, the Subbas lost all rights in these lands. A dispute in 1954 illustrates the immutability of this regulation.

Shortly after 1912 the Nembeke iubba Indra granted some kipat lands as a Holding to a Jaisi neighbour and appointed him a Thari. During the revenue settlement of 1936 the Jaisi registered the lands within the Holding as raikar. In 1954 Jahare, the son of Indra, sent his son Dharam to cut some leaves for their cattle from a nearby wood which was within the Holding given by his father to the Joisi. When the sister of the present Thari (the son of the original grantee) saw Dharam she

1. Sometimes, the Subbas were colled upon for assistance of a more personal nature. Found among some old papers belonging to a resident in the Cluster was a note, written in 1876, and addressed to a subba from a member of the administration in Ilam Bazarr. The correspondent, who was builaing a house, requested a rew bundles of thatch for his roof, which he suggested might be forthcoming from the subba's dependent households. 
became angry and told him he had no right to cut the leaves in this wood without her brother's permission. The young man cursed her and it is alleged that he struck her. When the Thari heard the commotion which ensued he came running and asked what had happened. Dhaxam told him that he was only a 'cowherd' (gothalo) on the land and did not own it since it belonged to the Subba who had made the grant. As such, Dharam insisted that he had every right to cut the leaves of the trees. When the matter was brought before a mediation panel Jahare was held to be at fault for sending his son into another man's wood. iven if the land had once been kipat, they pointed out, it had become raikar and the Subba or his descendants who made the grant no longer hod any rights in it. Jahare was made to promise that in future he would seek the permission of the Jaisi if he wished to cut leaves from the wood.

Jehare had set out to test the immutability of the srant which his father had given the Jaisi. He did this by sending his son to cut leaves without asking permission of the Jaisi, since ownership rights are recognized by requests for such permission. When Dharam used the term 'gothalo' he was repeating o word used frequently by Iimbus when referring to the relationship 
of the Tharis to the Moldings grented them by the Subbas. A gothalo tends the cattie of his master, but does not own the cattle. Likewise, the Tharis were supposed only to mind the lands entrusted to them by the limbus and take their products. The Irimbus insist thot the grants were given in good faith, and only the treachery (jal) of the recipients led to the conversion of these lands to roikar tenure.

Another development followed from the regulation of 1886: Tharis began to rely directly on the Government for their security of title. The Government, which had previously only guaranteed the Tharis a measure of security after appointment by the subbas, began to take a direct hand in their assignment. Although succession to the title by primogeniture was usually accepted, the authorities reserved the right of confirmation. If a Thari died without heirs or emigrated, leaving his Holding without a headman, the Government and not the Subba would make a new appointment, usually after consulting the dependents. For a brief period, Tharis were even allowed to sell their Holdings, subject only to the approval of the new Thari by the Government ${ }^{1}$. The rights and reeponsibilities of the Tharis

1. This right was abolished in 1911. 
no longer devolved Irom the iubias. Channels of communication led straight from the administration to the Tharis. The latter become answerable directly to the Government. The final collapse of the leadership hierarchy came at the turn of the century when the Tharis of Ilam began paying the taxes they collected from their dependents to the revenue office instead of to the Subbas ${ }^{1}$. Phus the Subbas were left to collect only the taxes assessed on their own Holdings of kipat. This rearrangement of the tax-collecting system relieved the Tharis of traditionel financial obligations to the Subbas. They were no longer bound to make mondatory contributions o: labour to the Subbas, even though they retained the right to demand this labour from their own dependents. The fee payable by a purchaser of land, which had previously been shered with the Subbas, became the sole prerogative of the Tharis. Such income bolstered their economic position, not only vis à vis their dependents, but vis à vis the subbas as well.

Even so, these new advontages only strengthened the trend towards the economic ascendency of the Tharis which had begun even before the conversion into raikar

1. I was unable to discover the exact jeor when this regulation came into effect. In other areas of Limbuan, Tharis still submit their tares to the Subbas. 
of Foldings granted by the Subbas. I hove already shown how Government kipat policy ond population pressures had combined to bring about large-scale mortgaging of kipat lands. The Tharis, because of the singular advantages gained through their position, were those most likely to provide the mortgage credit and become landholders of kipat pledged by Limbus. Thus, for example, all fourteen non-Limbus who are among the Main Iandholders of mortgaged kipat, are Tharis 1 . It seems possible to project this correlation back to the last decades of the 19th century, and to infer that the leadership hierarchy initially based on the system of land gronts was already on shaky economic foundations when the raikar regulations of 1886 were introduced. The Iack of coincidence between the political status conferred on the Subbas by the hierarchy and their economic stotus is demonstrated by a consideration of their land mortgages. Table 35 shows the percentage of lands owned by Subbas which have been mortgaged. The figures have chenged. Iittle since the turn of the century.

1. See p. 176. 
TABTE 35

Kipot rontestiod br Sibbes

Iineage

Chongbung Lineages

Kambo Iineages

Nembeke
Eercentage of Land

Mortgaged by Subba

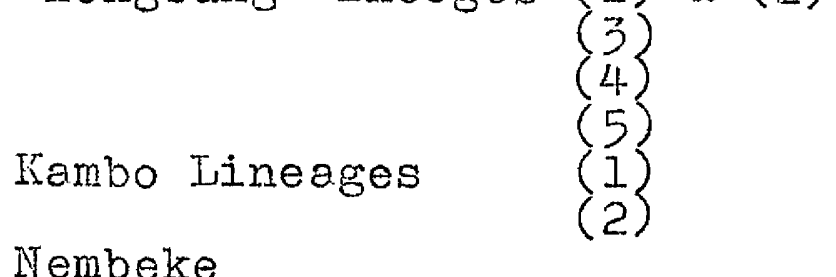

(1) \& (2)
$91 \%$

30

63

60

98

97

These figures support the contention that the economic base on which the leadership hierarchy was originally built was eroded by the tum of the century. The Government's restructuring of the tax-collection system wos fundamentally a recognition of this fact. The Subba's role as Government tax-collector on kipat holdings remains unaltered, and constitutes the basis of his formal authority. But most of his other traditional duties have been usurped either by the Tharis or, nore recently, by new administrative bodies such as the Panchayat Committee, described below. Still, the subbo remains a much respected figure among the Iimbus, ond the fact is recognized even by the Penchayat Committee which channels many of its instructions to the Limbus through their Subbas. Thus, for example, when each ward ${ }^{1}$ in the Village was required to

1. The Villege is divided into nine wards, each of which chooses a representative to the Eanchayat Committee. 
provide labourers for a road-building project, it was the subbas and not the word representatives who were asked to prepare a list of 'volunteers' from those wards containing the Indreni settlements.

There are two main reasons for the continued prestige enjoyed by the Subba. The first, which I consider in the next chapter, concerns his role as symbol of the unity of limbus in their opposition to the outside. The second relates to his dual role as mediator in minor disputes between Indreni Limbus and as a leading figure in negotiations over compensatory claims arising out of jari narriages. I consider the latter context first.

\section{Disputes over Compensation}

In an earlier chapter I alluded to the high rate (almost 20\%) of marriages by abduction of other men's wives. Such marriages precipitate crises on three counts. Firstly, they give rise to the possibility of violence. Becondly, they involve the severance of existing linkages between affinal groups which is potentially dismuptive since the groups in question are often related in a number of ways. Finally, they require the settlement of compensation claims and so have economic 
consequences which seriously arfect the fortunes of the households involved.

Although the use of force by a cuclolded husband. is no longer recognized in law, attempts to employ violence to gain redress for marital grievances are not unknown. When a Limbu of Bharapa abcucted the wife of another man, the latter's attempts to take revenge on the adulterer led to on outbreak of fighting between supporters of both men and resulted, in the words of one participont, in a number of 'broken heads'. Such occurences are rare since steps are taken to ensure that the new husband and the cuckold do not meet. Thus a Kambo man of Dorumba spent the best part of three days in hiding while the man he hadcuckolded conducted negotiations for compensation with the former's representatives. The explanation for the disappearance was that 'if the cuckold meets the man who has seduced his wife he must "cut" the latter.'

However, in the great majority of ceses rompensation is sought directly from the new husband only if the wornan has been abducted from her marital home. This is an uncommon eventualjty since both a husband and his kinsmen keep a close wetch on the woman's activities and woebetide the man who is discovered attempting to seduce the woman under their very eyes. Most abductions take 
place while a woman is at her natal home. I have shown that the ties between a woman and her natal group remain strong after marriage, with sisters and daughters visiting frequently and for long periods of time, and with many maritel separations leading to permonent residence of women in their natal settlements. This situation provides both the climate and the opportunities for the formation of liaisons with married women. Then a woman is seduced while resident at her natal home, the aggrieved husband generally seeks compensation from her natal household, which then reclaims the amount from the new husband.

To negotiate the terms of compensation and, in general, to effect the severance of existing or the establishment of new marriage ties are the tasks of representatives chosen by the households directly involved. I have been told, though this is impossible to verify, that traditionally this role fell to lineage groups led by the Subbos. The latter continue to justify their right to claim a special portion of any bridewealth in terms of the obligations they are prepared to accept on behalf of lineoge mates during negotiations over compensation. The Subbas indeed play an essential part in the discussions, although more in their role as 
figures of influence within the commitity than in their capacity os lineage headmen. The lineage group, if it ever was, is no longer e corporate unit in so far as negotiations over compensation are concerned. The households involved in these disputes must mobilize supporters on principles more varied then, although including, lineage agnation. It is important to stress that the strength of a household's support depends not on the number of persons it is able to recruit, but on what might be called the strategic qualities of those recruited. Although the numbers taking part in discussions vary from instance to instance, indeed, from hour to hour during a single case, the effective supporters of a household seldom number fewer than four or more than eight for ony compensation dispute.

What are the chief criteria for recruitment? Of first importonce is seniority. Although young men and women are invoriably the partners in jari marriages the responsibility for dealing with the consequences of their actions falls on their elders. Young men nay observe the deliberations of their elders, or answer questions of fact if asked, but none would presume nor be invited to porticipate in the talks. Seniority implies a number of qualities. To wrangle over compensation and to handle the delicate task of severing old 
affinal links requires patience, and a facility for selfexpression, which latter suggests an ability to converse in the idiom of Ijimbu tradition and customs. Such qualities cone only with age and experience. The importance of seniority is highlighted by on instance in which on Inareni Limbu found himself negotiating for compensation without the benefit of support from his elders. Then a young Chongbung man went to fetch his wife who had been visiting her natal settlement for a few months, he discovered that she had gone off with another man several days before his arrival. Instead of returning to the Cluster (a three day walk) to muster support he allowed himself to be persuaded by the girl's father to settle compensation immediately. His only supporter was another young man from the cluster who had come along for the trip. He was able to collect Rs 300 but he would have received much more, he insisted, if there had been some older men with him. 'We were two babies (balak) ageinst their elders (burdo).'

Not all elders possess the qualities usually associated with elderhood. In the Cluster men with the required telents are few and much sought after. In infomation obtained about twenty-eight cases of compensation disputes, the nares of ejoht men appear constantly 
among the supporters recruited by households from every part of the Cluster. All but one - who is 65 years old are between 45 - 60 years and possess the ability to present an argument forcefully and tactfully. They are all of above average wealth, although the richest Indreni men are not amongst them. These men command considerable prestige and influence among the Limbus. During talks, one supporter on each side acts. as chief spokesman, carrying the main burden of the aiscussion. Although any elder with orotorical talents can assume this role, ideally it should fall to a Subba, since it is felt his title alono commands respect. 'All men talk but a Subba must be listened to.' In $70 \%$ of the cases recorded a Subbo did act as spokesman, although in the majority of instances the household for which he spoke was not a dependent (roiti). In those cases where households were, by virtuc of owning kipat Iand, linked to subbas as dependents, only $40 \%$ were actualy represented by their own Subbas. Because most Iimbu headmen were either too young or did not have the necessary qualifications to be spokesmen onother 40\% of these households were represented by a Subba other than their own. In one case, for exanple, a Kambo man whose elder brother was a Subba, but still young and 
inexperienced, invited a Chongung Subbe to be his spokesman.

The Subba performs another important function in providing whe channel through which negotiations can be inaugurated. The residents from gnother settlement cluster who arrive to negotiate for compensation are expected to make the first formal stotement of their intentions to a Subba. If this is reglected, as it sometines id, the Subba could refuse to allow discusian to begin and certainly thregten to withhold his participation. By adhering to this custom, which includes the payment of a bottle of liquor to the Subba, the visitors ensure that the discussions will commence with haste and in an atmosphere of cordiality.

Neighbourhood is another important consideration when gathering support, since neighbours are first of all dependent on one another in a number of contexts and therefore thought to be reliable allies. Secondly, neighbours are expected to know the intimate details of the circumstances they are beine called upon to discuss. Since most Iimbus are neighbours to at least some of theis lineage mates, we might distinguish between the latter and neighbours who belong to other lineage groups. Thus, $60 \%$ of the households in the cases recorded mobilised non-lineage neighbours to support them, while 75\% 
included lineage kinsmen. Whis latter figure is of some significance since it indicates that one quarter of the households did not muster their lineage agnetes even though such were avoilable. Most households recruited both categories of neighbour.

Glose to half the households recruited nonIineage supporters from other neighbourhoods in the Cluster and even from settlements outside the Clustex area. These persons were brought in to negotiate for one of two main reasons: either they fulfilled some of the criteria already discussed, or because they could trace links in the opposing camp. If neighbours or lineage mates had similar links the need for 'outside' recruitment would have been unnecessary. The importance attached to the inclusion of supporters with matrilateral. or affinal ties to the opposition is illustrated by the following examples.

After Hlahang, a Kambo of Chitok had seduced the wife of another men and brought her to be his own wife, the woman's father and his supporters came to demand compensation 1. Of the four supporters recruited by

1. It is not uncommon for the rather of a wonan who has gone off from her natel settlement to seek compensation from the new husband before the cuclrold comes to claim from his ex-father-in-law. 
Alahang one, another Kambo belonging to a different lineage, was related affinally, through his third wife, to the father of Alahang's new wife. A second supporter, a Chongbung of Bharopa, was also mobilized partly because he had matrilateral ties in the same settlement cluster as the woman's father. By continualy stressing the importance of these ties, Alahang's supporters were able to dispel the initial hostility of the woman's father and his allies caused by Alahang's abrupt abduction of their daughter, and to reduce a first demand for Rs 1500 compensation to a final figure of Rs 600 .

In another instance, the married daughter of Sandu, a Chongbung, disoppeared after a dancing party in Angbung which was attended by some young men from the district of Panchther. Her husband, whose home was about four miles away, heard of her disappearance and came with his father and two other supporters to demand the payment of compensation. Here again, two of Sandu's supporters traced affinal links to Sandu's in-laws. The first two wives of one had come from the same settlement cluster, and the present wife of the other was a lineege sigter of the opposition spokesman. Since sondu could not pay the compensation, it was essential to postpone the discussions for os long as possible to give him the time to look for his deughter 
and her abductor, who had indeed disappeared, and to raise the compensation payments fron his new in-laws. After 8 number of refusals, the husband's supporters agreed to a postponement of one month on the basis of a personal guarantee from the husband of their lineage sister (and a supporter of Sandu) that at the end of the stipulated period the compensation would be paid.

Persons linked to both cornps, even when not taking as crucial a part in the discussions as those in the two cases cited, do tend to bridge the gulf between the negotiators and so omeliorate the bad feelings which jari marriages cai cause, while exerting a strong force for compromise.

Since virtually all jari marriages are between partners in different settlement clusters there are no universally recognized mediators such as there would be in intra-cluster disagreements. To an extent, the presence of Subbas and the common vocabulary of tredition and custom provide a framework within which discussions can proceed. But it is unlikely that any compromise could result from such negotiations without the inclusion on each side of supporters with interests in mainteining their links to both sides. Still, this is not the stated purpose for their recruitment. The household means to 
mobilize supporters and not mediators. One householder involved in such a dispute remarked: 'we want men who will carry us, not men who will compromise.' In this sense, the household musters an 'action-set' - to help it achieve a specific goal viz. the settlement of compensation on terms favourable to itself ${ }^{1}$.

In the process of their confrontation, however, these sets are gradually 'trensformed' into a: panel of mediation because of their interests in maintaining relationships which transcend in importance the immediate subject of their dispute. This becomes evident when it is noted that once recruited, a set will negotiate without the direct guidance of the household it is meant to represent, and will reach decisions which the members of both sets feel serve their own or the general interest. In the latter case cited above, for example, Sandu was entirely without control of his supporters, and did not wholly concur in the compromise they reached.

The inclusion in the household's set of Subbas and elders who are men of influence thus ensures that its case will be well represented, and at the same time guarantees that compromises reached will be respected.

1. For a discussion of 'action-set' see Mayer, 1966. 
Even the most powerful Jimbu households, olthough able to exert a greater measure of control over the sets they recruit and thus in a better position to influence the final decision of the mediation panel, would be reluctant to disregard this decision forfear of alienating the support of the Subbas and elders in future 1 .

\section{Intra-Cluster Disputes}

Informal Mediation

The Subba's statutory authority no longer

extends to the maintenance of low and order. The council of Subbas (amal), which existed until about 50 years ago, is now defunct? In consequence, most disputes between Iimbus within the Indreni Cluster are mediated

1. These mediation panels are unlike the 'councils of reconciliation' described by Cohen in that the mediators are not chosen by each side because they are neutral. In the sense that the sets which ultimately reach agreement regard themselves, at least in the initial stages of the discussions, as opponents representing different sides of a dispute, they resemble what Bailey refers to as an 'orena council'. (See Cohen, 1965, pp. 142-45 and Bailey, 1965, pp. 9-15.)

2. This is due partiy to the fact that Subbas have lost much of theis traditional power and partly to the spread of Government courts which usurped many of the functions of the amel. 
informally by men who are regarded as Notebles (bhaladmi). A man achieves notability with age, wealth and, increasingly, with literacy. Iie is expected to be fair and impartial when hearing disputes, and to possess the influence to make his decision acceptable to both parties. Still, the term is a vague one and depends not only on the context in which it is being used, but on the identity of the disputants. One man's Notable, so to speak, may not be another's. We might distinguish two categories of Notable. On the one hand there are the local variety, men who are regarded as Notables in each settlement or neighbourhood and who invariably help to compose minor quarrels between their neighbours. The Subbas and elders referred to above, for example, are regularly called upon to mediate in disputes involving individuals who recognize the higher status of the former.

To deserve the appellation of Notable on a Cluster-wide basis, however, demands validation by a status recognized in a wider context than the neighbourhood and even the Cluster. It accrues only to individuals with high status in the wider community. For reasons mainly connected with their economic impoverishment, none of the Subbas today enjoys the status of Notable in this sense; and to avoid confusion, it is in this latter sense only that I will employ the term. 
In the cluster toajy those who are regarded universally as Notables are army pensioners, more particularly, pensioners who combine literacy, age and wealth with 'high' military rank. Of these qualities it is only wealth, of course, which once attained, can be aissipated and lead to a loss of Notable status. To sustain a viable economic position over the years requires a combination of skill in managing a farmstead and a favourable balance of good fortune. That this is not always achievable can be illustrated by reference to one Chongbung ex-serviceman. As a result of the eighteen Jears he spent in the army he was able to repay a number of debts incurred prior to enlistment, to repossess his own mortgaged kipat lands and to take some other lands under nortgage. During the first three years following his return to the Cluster with the rank of a Havildar ${ }^{1}$ and a pension of $R_{s} 40$ per month, he invested in more land. Within ten jears, however, by a combination of unfortunate circumstances, shief among which were eight young children and a penchant for drink, the Havildar's household was anong the poorest in the Cluster. The status he imported from the Gurkhas is irrelevant in the context of Indreni Ieadership because of his present

1. H Havildar is roughly equivalent to sergeant. 
economic circumstances.

Another ox-soldier, a Nembeke, who attained the same rank and pension, has been able to maintain a viable estate, although with increasing difficulty because of his own jnvolvement in expensive litigation. Nevertheless, now in his early sixties, he is recognized as a llotable in the Cluster, and disputes are frequently taken to him for mediation. Thus, a quarrel between two brothers over the division of property retained by their widowed mother (jiuni) prior to her death was brought before the Havildar even though he was a Nembeke of Dorumbo and the disputants Chongbungs of Bharapa. The brothers threatened to tore the matter to court but were assured by the Havildsr that a fair solution could be found which would be satisfactory to both and moreover, which would save them undue time and costs. The procedure, as in mast instances of mediation was informal, with each disputant presenting his argument in tum and answering questions put to him by the mediator. Others joined freely in the talks and witnessed the signatures on the document setting out the terms which were finolly agreed upon - the division of the land into equal shares. The return to harmonious relations was signified when everyone present was invited to share a bottle of liquor. 
The aispute did not require the attention of a gifted mediator. The solution was obvious at the outset and could have been foretold by any Indreni man with an average amount of experience in these matters. Why, then, wos it brought to a Notable? When the question was put to one of the disputants he replied: "Why should we bring it to a Subba? He is no bigger than we are. If there is any quarrel about the decision in future, then others will tell us: "this is the work (decision) of a Noteble; why do you quarrel about it?"' The acceptance of mediation by men who are universally recognized as Notables thus ensures thot the decision is not iikely to be aisregarded.

The most widely acknowledged Notabias in the Cluster are two ex-soldier brothers of chitok. Both are known and addressed by their ranks: the elder, Lojahang, was a Iieutenant; the younger, Parsade, a Subedar 1 . Their pensions amount jointly to Rs 2280 annually. Between them they hove taken under mortgage 10.1\% of all kipat lands pledged by Indreni Iimbus ${ }^{2}$.

1. Under the system of ranking in the Gurkha Brigade prior to 1947, a Gurkho Ii eutenent was referred to as an Indian Commissioned Officer, while a Subedar was a Viceroy C.O. The latter ranked slightly below the former.

2. They are among the Main Iandholders ( $h$. and i.) distinguished in Chapter V. See Table 14, p.176. 
Lojahang also oms raikar lands in the Terai, purchased with his earnings during service, and from which he derives on income of approximately Rs 2500 per year. Both are considered to be among the wealthiest men in the area. Since their return from army service in the early 1950 s their assumption of leadership has seemed both inevitable and welcome. As the most important Notables they have to mediate in the greatest number of disputes. One quarrel, involving a Subba's son, is worth recounting since it illuminates the established. trend away from mediation and, more generally, from pollitical leadership by the Subbas, in favour of that provided by Notables who have achieved status as a result of army service.

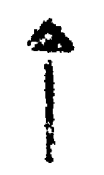

$\Delta$ Kabir Hang

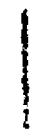

$\triangle$ Khem Bahadur

Fig. 7 .

In October, 1964 Kanak, the brother's son of Lajahang and Parsade Ioaned Rs 1 to Khem Bahadur, the son of subbe Kabir Hong, so that Whem Bahadur could remain in a game of caras some boys were playing. The following Jenuory, Kanak asked for the return of the money. It is alleged thet Khem Bahodur refused, and that there ensued 
an argument auring which the Subbo's son was beaten. When Kabir Hans heard what had taken place he discussed the matter with another Subba and both decided to hold a moot (in their 'amal', as they put it, using the term for the traditional Subba's court). Both Kanak and his father's brothers - but not his father, who is a poor man without influence - were summoned to the house of Kabir Hang where the moot was to be held. After some time a representative orrived saying that both Laiahang and Parsade preferred that the meeting be held at the former's house. Those who had gathered in Kabir Hang's courtyard then walked the half mile to the new meeting place.

Kabir Heng regorded the beating as a deliberate insult to the dignity of a Subbe. He insisted that 'the Subbe is a king, and to beat the son of a Subbo, is to beat a king's son' (and future king). The purpose of the moot for him wos to seek redress for this affront. The incident was regarded in quite different terms by the ex-army lieutenant. He pointed out thot it is against the low to gomble and that both boys were wrong to do so. He then reminded Konak that it is also agoinst the law to beet another, and thot $=$ court would deol severely with such an orfence. Kanak was then mode to present a 
bottle of liquor to the subbe, and to signal his apology by making obeisance to the latter anc to his son.

Two points are worth noting. Firstly, Lajahang, by insisting on holding the moot in his ow homestead, established his ow right to mediete as against that of the subbas. Secondly, the different value frameworks within which each interpreted the misdemeanor illustrates the divergent bases of the two kinds of leaders. Stated crudely, it is the distinction between, on the one hand, ascribed leadership founded on traditional norms and, on the other hand, achieved leadership validated by the norms of the wider society.

Athough it is often said of Iimbus that their disputes are never aired before members of other groups, in fact mediation is sometimes provided by another category of Notables who are not Iimbus. The status which most often leads to the recognition of a non-Iimbu as a Notable is headmanship on roikar Holdings $i . e$. the title of Thari. Until recently it was unlikely that a non-Limbu could achieve the qualities demanded of a Notable without the status and prerogatives enjoyed by a Thari. In rare instances, a local Brahmin or other high caste man could rise to a position of prominence in 
the administration in Ilam Bazaer. Then this happened, the prestige he imported into the settlement would generally be supplemented by the grant or purchase of a raikar Holding, thus providing him with a base frorn which to sustain his externally-derived wealth and influence. Nowadays, in theory at least, a man can gain prominence through the new odministrative structures, such as the Fanchayat Committee. But in fact, as I will.show, this is highly unlikely. In the region of the Indreni settlements, while not all Tharis sre Notables, there are no non-Iimbu Notables who are not also Tharis. The nature of the relationship between a raikar headmen and his dependents relates, to a lorge extent, to the spatiel distonce between the Thari and his Holding. Because of the early practice of sale and purchase of Holdings as well as the introduction of a category of Government-appointed headmen, a Thari's residence often does not coincide with the location of his Holding. Of the sizr Theris resident in the Indreni Cluster, only one, a Jaisi of Dorumba, actuelly resides on his own Holding. The other five Tharis - oll Brahmins - have their Holdings anywhere from one to six miles awoy from their homes. As can be seen from the following lable, three of the tharis resident in the Indreni settlements 
have more than one Holding.

TABLIE 36

Holdings of Indreni Tharis

Thari $\begin{gathered}\text { Thari's } \\ \text { Residence }\end{gathered} \quad \begin{gathered}\text { Iocation of Holding } \\ \text { (distance from residence) }\end{gathered}$

Brahmin (1) Bharapa

Brahmin (2) Chitols

Brahmin (3) Chitok

Brahmin (4) Chitok

Brabmin (5) Dorumba

Jaisi (6) Dorumba
I mile
(b) 6 miles
(b) $1 \frac{1}{2}$ miles
(a) 6 miles
(b) 2 miles
$1 \mathrm{mile}$
(a) Dorumba
(b) 3 miles

The raikar lands within the Indreni settlements are divided amongst four Tharis, three of whom - the Jaisi being the only exception - live outside, but within a three mile rodius of the Cluster.

Due to the nature of roikar lond, the Thari is separated from his dependents in more than a spatial sense. Other than the fact that Holdings could be transferred by sale, raikar lands themselves can be alienated so that, over time, the composition of the Holdings' residents may change substantially. Thus, in contradistinction to the Subba, the Mhari is malikely to be a kinsman to more than a few, if any, of his dependents. The result is a relationship betweon dependents and Tharis 
quite distinct from that between Subbas and their dependents.

For a number of reasons it is to a Thari's advantage to keep in close touch with his Holding. For one thing, he is able to exact the traditional five days of lobour, despite the fact that such exactions are now outlawed. For another, he can ensure that dependents turn up at Dasein with their tributary payments. Thirdly, since a fee following the sale of any land within his Holding is still paid to the Thari, it is in the latter's best interests to be in touch with all developments, so as to know if the price mentioned in the documents of sale is in fact the real male price. Still, it is not in a Thari's interests to emphasize his prerogatives to the exclusion of his responsibilities. A Thari should be ready to offer financial and other kinds of assistance to his oependents during times of distress. He should also be prepared to help his dependents in their occasional dealings with the administration. And he must be ready to offer his services in mediating disputes. The Jaisi headman in Dorumba, for example, has on severel occasions attempted to seek a solution to a bitter antagonism existing between two Kanbo brothers and their wives, who reside 
on the Jaisi's raikar Holding. In the most recent incident, the wife of the older brother was severely beaten during a drunken quarrel by the younger brother and his wife. Since the case was one of assault, it was cognizable by the court, but the thari convinced the injured party that on official complaint would only involve everyone in endless appearances in court and untold expense, and stressed that 'brothers should not show their quarrels in public'. He then beld a moot where it was decided that the aggressors would paj the injured woman $R s$ 1.60 to 'raise her head' $i . e$. prestige (sir uthaune).

A Thari who is known to be fair in his demands and generous in his assistance earns not only the accord of his dependents but of his peers and neighbours, even if the two categories of persons are spatially quite distinct. Thus the reputation earned by a Thari through his relationships with his dependents gives him Notable status in the area of his Holding as well as in the settlement region where he resides.

Two cases serve to illustrate the foregoing remaiks.

A poor Brahmin from a settlement just west of Bharapa, had asked a Iimbu widow of Angbung if he might take some bamboo from a small wood belonging to her son. 
While he was cutting down e tree he wes apprehended by the woman's son who threatened to beat him. At that point a Brohmin Notable retuming home from the Bazaar heard the two men quarreling and suggested that they explain the matter to him. The three retired to the courtyard of the Limbu's mother where the matter was clarified. The Notable exacted an apology from the Limbu for his hasty accusation and a promise from the Brahmin that in future he would seek the Ijmbu's permission directly if he wanted to cut bamboo from the wood. The Notable, a Brahmin Thari of Chitok, had no specific kin or political relationship with either of the disputents. His Holding was situated about six miles to the north of the Cluster, but his status in the Indreni area dexived from his reputation as a man of wealth and influence, and his mediation attempts were both welcome and effective.

In another instance, the mediator was a man with similar Notable status, who was headmen of a raikar Folding within the Indreni settlements, though he was resident severol miles away from the Cluster. The dispute involved a Chongbung of Chitok who had cut off the ear of a goat belonging to a Brahmin from a neighbouring settlement because the animal had come unattended 
into the Iimbu's potato field and destroyed part of the crop. The Thari, who was asked by the owner of the goat to settle the matter, upbraided the Iimbu for not tying up the animal and then claiming compensation for the crop amage. It was decided that the limbu would pay the owner Rs 32 and keep the goat. The owner demanded a promissary note from the timbu, but the Thari insisted that this was unnecessary and that he would guarantee the payment, since both men owned a plot of raiker land in his Holding.

Thus Notable status within the Cluster can accrue, on the one hand, to Indreni Tharis who exercise ot least a port of their leadership roles in Holdings renoved from the Cluster, and, on the other hand, to Tharis resident outside the area but whose political bose, as it were, is within the boundaries of the Indreni settlements.

In sum, then, there are a variety of informal. mediators available to settle disputes in which Limbus are involved. The decision as to which category of mediator to choose depends partiy on who a man is quarrelling with, and partly on the disputants' personal. assessment of their om status. The first is of importance because limbus prefer, but as is obvious from some of the examples cited, do not always succeed, inheving 
their quarrels mediated by other Limbus. The second determines the 'level' at which mediation will be sought. The higher an individual perceives his own status, the higher will be the level to which he turns for mediation. Thus, 'small' men turn to subbas and other men of influence in their neighbourhoods; 'bigger' men seek mediation from one of several categories of universally recognized Notables. This explains the tendency for the decisions of informal mediators to be respected. The acceptance of their superior status is at the same time the strongest sanction of their mediation.

But informal mediation is only one area of choice open to disputants. There are also formal bodies to which men can turn for the redress of their grievances. They are the statutory Ponchayot and the vorious adininistrative offices, including the court, in Ilam Bazaar.

The Penchayat

The first attempts to introduce statutory Ponchayats in liepol dete back to $1926^{1}$. In that yeer, experiments in local govemment were carried out in the region of Kathmandu Valley and in 1930, were expanded to include

1. For a good discussion of Panchayats in liepal see Rose, $1963 a$. 
four districts in both the hill areas and the Terai. It was not untiz 19/48, however, that legislation was introduced allowing for the establishment of Village Panchayats throughout the country. At that time a Fonchayat Committee was formed of representatives from settlements in the Ilam-Darda sub-division of the district, which was constituted as a single 'village'. However, the revolution of 1951 aborted the Panchayats before they could begin functioning properly.

In 1953 the system was re-introduced, but this time Ilam-Darda was divided into three 'Villages'. A]I Village inhabitants over twenty-one years of age became members of a Village Assembly (sabha) which met twice annually to approve the budget and discuss the development programmes before it. The members of the Assembly also chose nine men to represent them on a Panchayat Comittee, and the latter in turn, selected their own chairman and vice-chaimman. The Government appointed two prominent men of the area to act as president and vice-president, responsible for the proper conduct of the Panchayat Comittee's business and, generolly, to oversee its functioning. idditional supervision wos provided by a Jistrict Fanchayat and a specially created Government department which audited the accounts of the Committee, approved its programme and had 
the power to suspend the body or any of its nembers. The main ains of the Panchayat, es set out in the Panchayat Jew, were to implement Government progremmes for welfare and development, collect essential census records and maintoin law and order. The greatest ernphasis was placed on the latter responsibility, and a Penchayat Court was esteblished whose jurisdictional boundaries were defined by a special Act. The Court was empowered to settle cases involving damages up to Rs 100 and for which fines of up to Rs 25 or imprisonment for up to three months could be meted out. In addition, it could offer mediation facilities for all coses regardless of the amount of domoges involved, provided they were not cognizable by Government courts. The Fanchayat Court consisted of five inen chosen by the chairman of the Panchayat; Comnittee, two of whom had to live in or nearby the settlement of the litigants and so be familiar with them. Miembers of the Court had also to be rotated on a regular basis, with no member serving more than one month at a time. The chairman or vice-chaiman of the Committee wos required to attend all sessions of the Court.

In the four year period during which the Panchajat was in existence, the Court entertained 
approximately 200 cases. It seldon used the powers given it by the Law. Instead, the Court sought to effect a cooling of tempers and to promote compromises. Acceptance of Court mediation of one dispute did not necessarily mean that the same litigants would not reappear before the Court under a different pretext. Where factional issues were involved Court mediation afforded only a temporary lull in the storm of litigation.

Indreni limbus tended not to bring their disputes to the Panchayat Court. In three of the cases in which a Iimbu was involved, the litigation was initiated by a member of another caste. In one instance, a Kambo man was accused of beating a Brahmin over an irrigation dispute. In another, a Chongbung was alleged to have deliberately damaged a Blaclssmith's crops, while a third case involved a Limbu who had purchased a bullock given as security to a third party. In only one case did a Limbu prefer charges; against a Brahmin whom he alleged had cheated him over repayment of a loan. The reluctance of timbus to bring their quarrels to the Fanchayat Court is explained partly by their preference for informal mediation by other Limbus, as I have pointed out, and partly by their cpposition to 
the Pancheyat system in general ${ }^{1}$.

The present Panchayat Comittee, established

in 1962 under a reconstituted system of Ianchayat Raj, retains many of the structural features of the previous body ${ }^{2}$. But the area under its jurisdiction i.e. the Village - called Syawa - has been reduced to about onethird of its former size. The Village has been divided into nine wards. The settlements of Bharapa and Chitok together constitute a single ward, while households in Angbung and Dorumba are bunched together with those in neighbouring settlements to form two other wards. The posts of president and vice-president have been abolished so that the effective head is now the Chairman chosen, as in the past, from among the members of the Panchayat Committee.

Under the present system, the emphasis is laid on the encouragement of 'self-help' development schemes, and involvement in judicial matters is actively discouraged. Not only has o Panchayat Court not been established, but a Panchayat Committee which seeks to utilize the powers previously held by the Court must

1. See Chapter VIII.

2. Another Panchayat fict was introduced in 1956, but no measures were taken in Ilam to set up Panchayat Committees. 
request special euthority from the Government. The Panchayat Comittee, however, reteins the right to offer its good offices to effect compromises when both disputants voluntarily seek mediation. Obviously, the distinction between Court and mediator is not as finely drawn in proctice as in the Panchayat Law. The main result of the emphasis on development work, however, has been to shift the mediation platform from the Committee meetings to the courtyard of the Committee Chairman where, sometimes slone, and occasionalyy together with other representatives, disputes are heard and composed. The mediation is not informal because the Chaiman acts with the full. authority of his position, and there is all but the force of law in his decisions. This will be evident from the following examples.

In 1963, following the death of his wife, Budibal, a Nembeke of Dorumba, brought an Angu woman of Bharapa to live with him. The woman was separated from her own husband, whose whereabouts were not known, and so since Budibal had paid no compensation, he did not consider her his wife, although she was referred to as such by everyone in the Cluster. The womar was subject to periodic moods of depression and sudden 
outbursts of violence. After one incicent, durine which she threw a khukuri knife, narrowly missing one of Budibol's young children, he decided that he could no longer allow her to stay in the house. Budibal and his two brothers met with several Angu men to seek a solution to the dilemma. Ihe Angus insisted that this was a domestic quarrel and should be settled within the household. If a wife is troublesome, they pointed out, a man cannot send her away, but must take the good with the bad. The Nembekes, on the other hand, stated that a wife is brought to make a house happy, and if she is unable to do so, she must be sent away, or at least another house must be built for her to live in. Budibal, however, was adamant about being rid or her, and based his determination on the danger to his children, thus shifting the nature of the dispute from a domestic quarrel to a public offence. Several. representatives from each side were chosen to present the case to the Chaimman. At this point, Budibal enlisted the support of Lajahang, the ex-army officer, who wos the father of Budibal's late wife, and the grondfather of Budibal's children who were alleged to be in danger from the uncontrollable anger of the woman. The Chairman agreed that the woman constituted a danger to the children. He suggested that she be given Rs 50 
to 'Iift her prostige' and that she return to her natal home in Bharapa. This is in foct what was done. The case provides on interesting contrast between what might be called the 'domestic' dimension of the dispute, in terms of which the supporters of both the husbend and wife sought a solution, and the 'legalistic' dimension, which approach Budibal adopted, probably in anticipation of the Chairman's own view. This is not to suggest that the first is a traditional approach, while the second a modern, since the presence nearby of police and court has long ago brought the law into the Indreni Iimbus' perception of their surroundings. But it does indicate a more immediate and effective presence, in the form of a banchayat Comittee, of the Porce and authority of Government. Indreni limbus are increasingly encouraged to take adventage of this stress by the Committee mediators on the legolistic dimension of disputes.

A Chongbung of Bharapa, for exmple, had borrowed Rs 180 and agreed to pay interest of $20 \%$ per annum. When it came time to collect the interest the creditor, a Brahmin from a neighbouring settlement approachea the Iimbu but the latter refused to pay, claiming the interest was too high, and suggested the matter be brought to the Chaiman. The latter scolded the limbu for refusing 
to meet his obligations, but conceded that the law set a limit of $10 \%$ on interest payments. The initial document was torn up, and a new one nade stipulating the legal rate, and the Iimbu was instructed to pay the amount within a month.

The Administration

The administrative offices in Ilam Bazar provide additional avenues for settling disputes. In addition to the Government court, both the treasury department (mal) and the office of the Governor have traditionally provided facilities for the settlement of disputes. This is party due to the blurring of jurisdictional boundaries between various branches of the administration and probably also a manifestation of the jockeying for power among the top officials. Other reasons are the high costs of court litigation as compared with disputes taken to the Governor or treasury and the relative speed with which these branches dispose of cases as compored with the time taken by the courts. Decisions from all these sources have the force of law. In consequence, inhabitants of the settlements of Ilam view the administretion as undifurentiated. Dealings with the Governor or his representotives, with the 
treasury officials or the court are seen as deelings with the 'offjce' (adda). And it js not uncommon to seelr redress for grievances concurrently in more than one branch of the administration.

I was not able to discover what proportion of disputes brought to Ilam Bazaar go to each branch, or what wos the nature of the disputes submitted. From a perusal of court records since 1951, however, several facts emerge 1 . Firstly, the majority of disputes taken to court are over land. Of forty-eight cases involving litigants resident in the Indreni settlements, twentythree cases concerned land disputes. Another ten were complaints about assault. Secondly, Limbus were litigants in only five of the court cases; three of these dealt with assault on other Indreni Iimbus, while two were land disputes with Brahmins. Thirdly, in forty-two of the forty-eight cases, at least one member of a single Brahmin lineage in the Cluster was implicated. This letter fact relates to the existence of factional cleavages in the Cluster, the nature and leadership of which are now considered.

Factions

For most Notables, the display of leodership

1. Most records of the court prior to 1951 were destroyea. 
qualities is confined to contexts of mediation. Some, however, become political leaders by gathering about themselves a core of followers whose ranks ore augmented on particular occasions by additional supporters. The immediate purpose for their recruitment is generally the waging of a dispute, but the underlying goal is the pursuit or maintenance of power or influence by the leaders. The followings such men muster will be called factions 1 .

Practional divisions bearing on the Indreni settlements are not confined to the Cluster, but extend throughout and, to an extent, beyond the Village area. The activities of factions, however, will be considered only insofar as they concern political alignments within the Indreni Cluster. The background to factional struggles will be discussed first.

Factions in the Indreni settlements are based on a schism within a single Brahmin sibling group. The origins of the split con be traced to 1925 when Loka Nath (see Fio. 8) purchased some raikar land in Chitok

1. The definition of faction which I prefer is eclectic: a leacier-based quasi-group, recrujted on diverse principles, and operating in the politicel field. This combines the definitions of factions given by Nicholas (1965) and irirth (1957) with 'layer's use of the term 'quasi-group' to indicate an egocentred, noncorporate collectivity of individuals. (Mayer, 1966). 
and Bharapo and moved with his wife and four of his five sons into the Cluster. lhe eldest son remained in the house where he and his brothers had been born, and which was situated in a settlement on the outskirts of Ilam Bazaar. The move corresponded with a division of property among the three eldest brothers Ram Chandra, Narad Muni and Gobindra and their establishment of separate households. Gobindra came to Bharapa, while Narad Muni and his father Ioka Nath built their homes on neighbouring plots in Chitok. The two youngest sons, Bishnu Prasad and Tunka Nath, who were only 17 and 12 years, continued to live for a time with their parents.

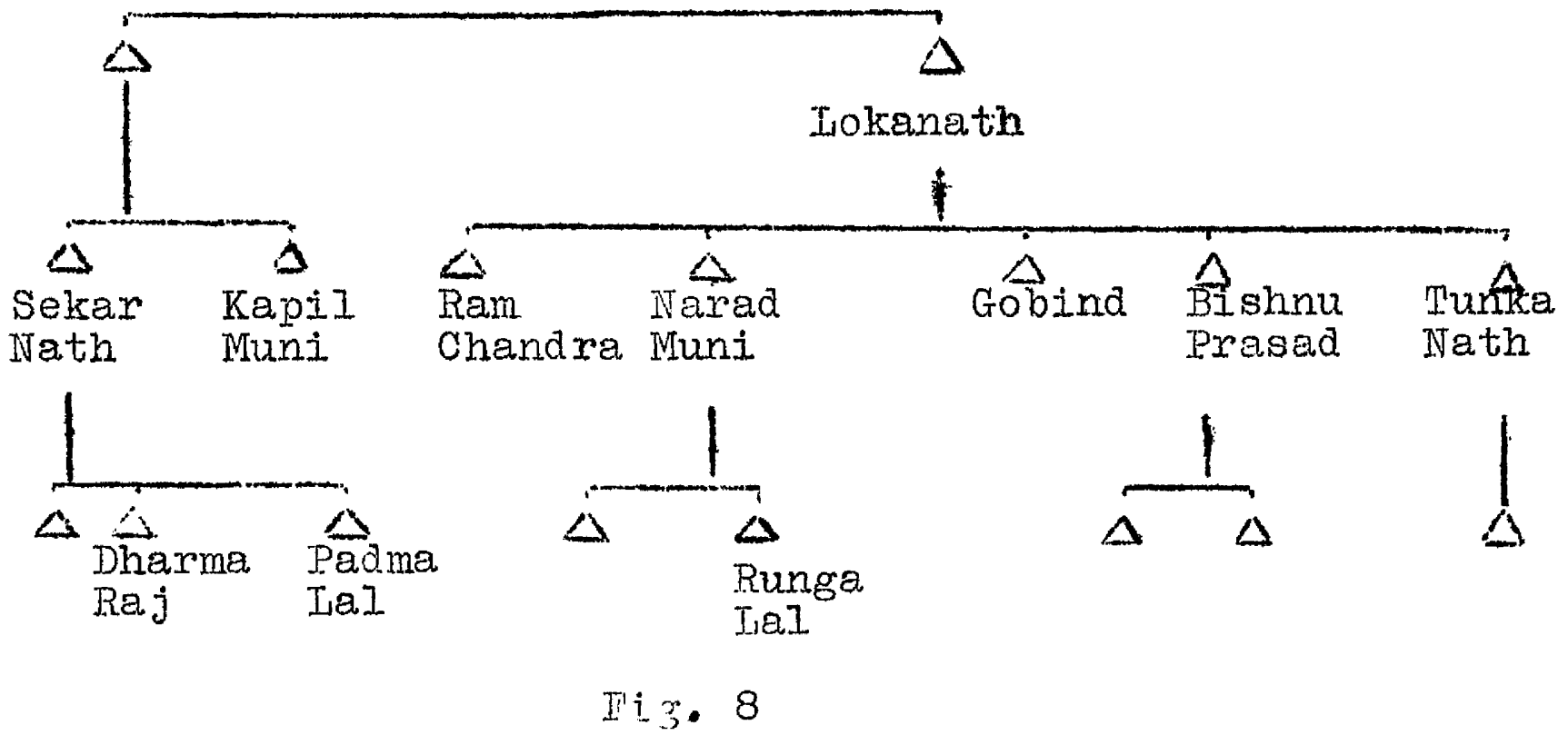

As is customary, not all the property was divided amongst the sons. A portion (jiuni) was kept by the parents to guarantee their own security in old age. 
The jiuni consisted mainly of forest and grazing lands as well as title to a Holding on other cultivated lands, all of which were situated about six miles north of the Cluster. The lands and headmanship had all been acquired by $\mathrm{L}_{\text {oke }}$ Nath as a result of his atteining a high position in the district administration. st the time the division of property agreenent wes prepared, it was stipulated that following the death of both parents, Narad Muni would succeed to the title of headman and receive the income from the Holding. The remeining forests and grazing lands were to be divided amongst Narad Muni, Bishnu Prasad and Tunka Nath. But a further stipulation required that the son who cared for his parents in their old age would, following their death, receive a larger share of these lands than the others.

In 1931, Loka Nath died. Shortly after, Bishnu Prasad established a separate household in Chitok. Ioka Nath's widow lived with her youngest son Iunka Nath until her death about ten years ago.

The death of Loka lith set the stage for a series of disputes among the sons stemming initially from disagreements over the division of the jiuni, and then becoming generalized in a wide range of contexts. Uithin the sibling group, the brothers formed a series of 
temporary alliances which dissolved with the settlement of a particular dispute or series of disputes, or upon the death of one of the brothers. Still, over a period of time, alliance patterns are discernible. The earliest disputes, following the death of Loka Nath, concerned mainly Ram Chandro and Narad Mini. Bishnu Prasad and Tunka Nath were still young men, while Gobindra spent most of his time in the Terai where much of his inheritance was situated, and so was never involved in his brothers' disputes. st the time of the revenue settlement of 1936, Narad Muni succeeded in registering in his own name all the jiuni lands which he was to share with his brothers following their mother's death. This led to prolonged court action which eventually ended with a Supreme Court decision in favour of Ram Chandra, who had pleaded the case on behalf of his mother and his other brothers.

From 1940-1950 Narad Wuni wes aligned against each of his brothers in turn, although occasional disputes broire out between Ram Chandra and Bishnu Frasad as well. By this time, the contexts for strife were not only their ow disputes, but quarrels concerning others as well. Thus, when Narad Mun's first wife brought him to court for selling her own private property, she was supported by Bishnu lasad. 
H.fter the death of Ram Chandra in 1950, both Bishnu Prasad and Iunika Nath quarrelled separately with Narad Muni and, on occasion, Ellied themselves against bim. By this time, moreover, the sons of Narad Muni and Bishnu Prasad has become protagonists as well. In one case of assault, each accused the other of instigating a beating because of a dispute over rights to an irrigation channel.

In 1956, following the death of Narad Muni, the only two remaining brothers, Bishnu Prasad and Tunka Nath, became the principal protagonists. When I arrived in the field, these two men were the leaders of factions which ramified throughout the area of, and, to an extent, beyond, Syawa Village.

How were factions composed? Each faction had established a 'core' of adherents, who tended to support their faction leaders whether the immediate dispute concerned them directly or not. The core included, first of all, the members of a leader's household. This is not as obvious a statement as it may seem. The ethic which exhorts a father to distribute his property (and his love) equaliy amongst his sons is occasionally ignored in practice. Fathers.often favour particular sons or the sons of a particular wife. Since property 
divisions are frequently determined before the sons establish separate households, such proctices cen result in a disenchanted son joining an opposing alliance against his father while still a member of the latter's household. Thus one of the sons of Narad Muni became an adherent of his father's elder brother Ram Chandra because of grievances against the former over property division.

As long as an estate remains undivided, a father can count on the support of members of his household. Both Bishnu Prasad and Tunka Nath head joint-type households, with two sons and one son respectively, who constitute part of their factional cores. One son in each househola plays a key role both as advisor and as a highly importent link with the administration where the two are employed.

Aside from household members, factional cores a.lso include men who, in the furtherance of their own cmidtions, find it expedient to seek the support of faction leaders. Hbsorption into factional cores may also have a basis in a history of disputes. Those led by Bishnu Presad and Tunka Nath included two brothers of a collateral line in the same lineage who had been at loggerheads for almost fifteen years. The initial 
antagonism developed at the time of their division of property. The elder, Dhanme Raj, alleged that his younger brother ladmalal had received a larger share of the estate than he did. The hostility between the brothers was exacerbated by the fact that their father, Sekar Nath, lived, during his old age, with his youngest son and was commonly known to favour the latter. Alignment with the primary faction leaders came about in 1952. At thet time Hadmalal was discovered to have impregnated the wife of an older brother who had emigrated to India. To cover up the scandal one of the dependents of Sekar Hoth, who was a Thari, was paid handsomely to take the woman away from the area. The arrangements were made by Tunka Nath in return for support given by pekar Irath during an earlier dispute. Dhame liaj refused to retain commensal relations with his younger brother, as did a number of other men in the area. Fadmalal, to save caste, was forced to distribute much of his wealth in the form of bribes, and had to sell a number of his lands to meet the costs. Tunka Nath was one of those who agreed to interdine with him (even if at some profit to himself) and since that time the latter has supported, and been supported by, the faction leader. In consequence, Dharma izaj was brought, 
somewhat inadvertantly, into the core of Bishnu Prasad's faction.

When Sekas Nath died in 1961, the two brothers, after observing a mouming period of one year, began campaigning for their father's title of I'hari, along with Sekar Noth's younger brother, Kapil Muni. Wach had in fact been sharing the income from a designated number of households within the Holding, but the title itself could not be shared $i . e$. the Holding could not be formally divided. The treasury office, which makes the formal appointment, decided at one point to seek the 'advice' of the dependents on the Holding. In preparation for the visit of the treasury representatives, each candidate enlisted the support of the faction leaders. Although Bishnu Prasad, by this time a Ponchayat Committee executive, could not campaign openly in favour of Dharna Raj, his support was commonly known and another member of his fection core conducted the campaign. Tunke Noth himself spoke in favour of Padmalal and, in on attempt to impress the treasury office of the strong opposition to Dharme Raj, who was the favourite by virtue of being the eldest son, Munka Nath encouraged another member of his faction core to bolster the clain of the third candidate, Kapil Muni. The meeting's only ensured thet eoch candidate would have the 
support of those households already paying taxes to him, since no dependent attended the meetings of his rivals.

In the end the treasury office heard only a few mild speeches in favour of each candidate without bringing the motter to a vote. Although nothing had been decided when I left the field, the general consensus was that the contest was a facade since the authorities generally follow custom in choosing the eldest son - in this case Dharma Raj - to succeed to a headman's title. The campaign continued behind the scenes by intermittent visits to the treasury office made by the competitors and their faction supporters. Two other men resident in the Cluster belong, together with Dharma Raj and Padmalal, to the core of the factions recruited oround Bishnu Prasad and Tunka Nath. Here again, alignment on a regular basis has resulted from the growth of intense hostility between a Jaisi and a Nembeke of Dorumba. The rivalry stems from a dispute over rights to land which the father of Jahore, a Subba, had granted as a Holdine to the father of the Jaisi, Bhagi Rath ${ }^{1}$. The latter aljied himself with Bishnu Frasad, who had already been at odds vith Jahare in a number of minor squabbles.

1. See above, pp. $307 \mathrm{ff}$. 


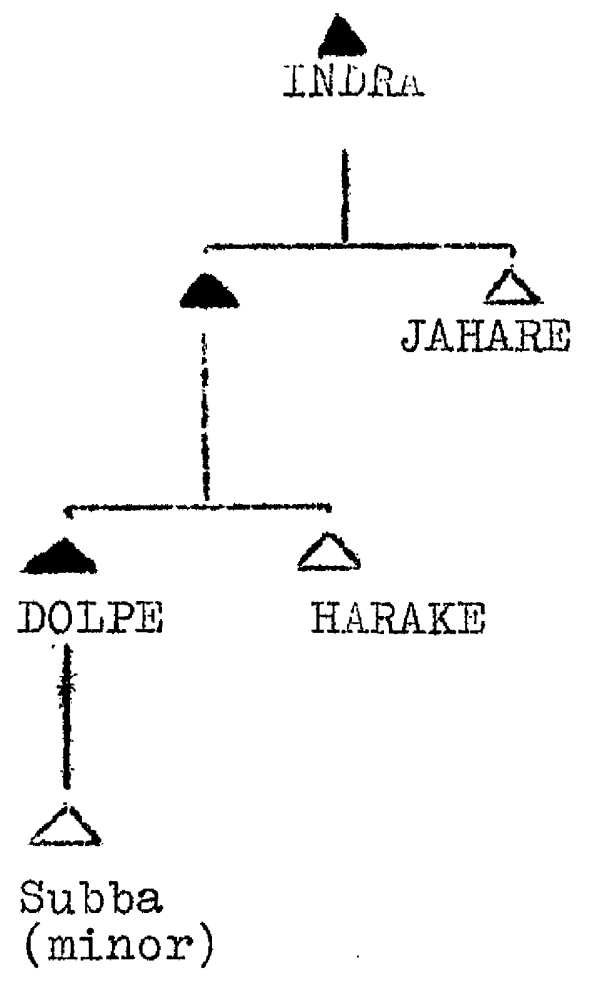

Fig. 9

The first major test of the coalition came in 1961 when Jahare attempted to claim the title of Subba after the death of his brother's son, Dolpe, who had inherited the title while Jahare was in the army. Although both customery and legal rules stress succession by primogeniture, Jehare challenged the right of the late subba's son to succeed on the grounds that the latter was a minor. With the help of Tunka Nath he was able to convince the treasury office that the dependents on the Folding should be allowed to decide the issue. rluey then went on to 'pack' the hearing by recruiting seventeen supporters from all parts of syawa Village, including five Indreni limbus, to eppear before 
the treasury representatives, who subsequently ruled in Jahere's fovour.

Bishnu Prasad and Biogi Rath then persuaded Harake, the late Subba's brother, and also a dependent on Bhagi Rath's raikor Holding, to appeal against the decision. They pointed out that the hearing, on which the treasury office decision was based, could be shown to be illegal, since most of Jahare's supporters who apperred before the hearing were not in fact dependents on the kipet Holding, but men resident on other Holdings. They then suggested that Harake emphasize that a minor's rights had been violated by the decision. If Harake would agree to act as the boy's regent until he came of age, the responsibilities of tax-collection on the Holding would be properly dis charged. Harake agreed to appeal and documents were prepared by the faction leader and his core adherents. Capital to fight the case in an appeal court in Kathmandu was supplied by Bhagi Rath, who took some of Harolie's kipat lands under mortgage. The original decision was eventually reversed, and the boy appointed Subba, with the stipulation that Harake would act on his behalf until he come of age.

In addition to their own households, Bishnu Prasad and Tunka Nath cen count regulariy on the support 
of four other households (between then) within the Cluster and perhaps another six in settlements outside the Indreni area. Factional cores, then, are small. There are several reasons for this. Firstly, unless a man has political ambitions, the risks involved in comitment to a faction core are too great. These risks are mainly finoncial. A core adherent may have to invest substantial sums of money in long drawn out struggles without any certainty of success. The costs to Jahare of his battle for the title of Subba, for example, were in the region of Rs 1200. Hence few men are able or prepared to comit themselves to a faction leader unless they are regularly in need of support. There are circumstances when a politically ambitious man has no choice but to align himself with the core of a faction leader: as, for instance, when a traditional enemy gives his support to one leader, and forces his opponent to seek the security of the other.

A second reason for the limited size of cores is that faction leaders seek adherents who are more then mere syncophents. Core supporters must possess attributes which redound to the benefit of a faction. In addition to wealth, litcracy is an essential criterion of core meinbership. Iiterocy in this context refers 
especially to a capecity to compehend the Legel Code, a formidable document of immense complexity, and a totel inystery to all but a few. Since most disputes involving substantial amounts of property or other wealth find their way to court, someone with a facility for supplying legal stratagems is a major asset to any faction 1 . Rien with ability to comprehend the witten word and to prepare petitions and counter-petitions based on legal arguments are of prime importance to a faction leader. Inceed, these are essential qualifications for faction leadership itself.

The term core suggests, of course, that a faction leader does rely in his political activities on other occasional supporters as well. Both leader and core adherents generally possess the means to recruit supporters through relationships esteblished in other contexts. Dependents on Holdings are one such source. Faction leaders Bishnu Prasad and Tunka Nath are both Tharis, as is Bhagi Rath; while Dharma Raj and wadnalal, who were disputing over their father's title, had nevertheless estoblished headman-dependent-like ties with a number of households within the Holding of their father.

1. Until recently, court officials were political appointees without legal training, so that the court itself was less than capable of coping with the highly complicated law. 
When Bishnu Erasad and Bhagi Rath opposed the claims of Jahare to the title of Subbe, Bhagi Rath was able to bolster his faction's case by recruiting several of his dependents to sign as witnesses on the petition presented to the appeal court.

Mortgege and loon credit, as well as tenancy provide aditional ties which faction leaders and core adherents can menipulate to recruit suppocters. AII, for exomple, are among the Main Landholders listed in Table 14 (p. 176). When the sons of Nared Muni and Bishnu Frasad accused each other before the Panchayat Court of assault each presented a number of 'eye-witnesses' to the event testifying to their opponent's guilt. Several of these witnesses were Limbus dependent on the faction leaders for credit or tenancy rights who were recruited to the factions for the duration of the case. Relationships of kinship, occasionally of agnation, but more frequently of affinity, provide another fund of potential recruits. Because Brahmins and Jaisis comprise the majority of the population in the region, nembers of these castes, especially wealthy families, are able to find spouses in nearby settlements, and so tend to have at least some of their affines and matrilaterol kinsmen close at hand. Moreover, ties to certain kinds of relatives are bolstered in a ritual 
context since, for example, sister's' husbanàs or sons, fathers' sisters' sons or daughters' sons con perform services as ritual priests (purohit). lit one Shiva ritual sponsored by a core adherent of lunlwa litath, eleven relatives in the category of purohit to the host were invited to participate in the ritual, and were appropriately fed and paid. Such men constitute an additional fund of occasional faction support.

Finally, the status of Irotable enjoyed by faction leaders places them in a position to do a variety of favours for others which accumulate as political debts to be collected at some future date ${ }^{1}$. Thus, a Limbu who had been accused of injuring a Brahmin in a quarrel sought advice from Bishnu l'rasad who prepared his counterpetition to the Eanchayat Court. Some time later, a witness was required by Bishnu Erasad to attest to the Jatter's presence in a particulor location and at a particular time to belie a charge that the faction leader hod instigoted an assault on a member of the opposing faction. The debt owed by the Iimbu was collected, and the charge against the faction leader was dismissed.

1. Faction leaders act both as 'patrons', when allocating favours to clients directly, and as 'brokers', when obtaining these favours as intermediaries. (Cf. Nayer, 1963). 
Notables also accumulate a store of favours because of their role in mediating disputes. st man who has sought and received justice at the hands of a Notable would be reluctant to refuse his support when called upon.

On the other band, those from whom support is sought by faction leaders are often placed in a dilema by overlapping claims to their allegiance. 'Debts' bosed on economic, political or kinship ties often link potential supporters to both faction leaders.

When a man finds himself in such circumstances he attempts to disengage completely from factional struggles. The dispute over the title of Bubbe provided one such occasion. Several of Jahare's affines were also dependents on Bhagi Roth's raikar Holding in Doruma, and efforts by both sides to enlist their support were assiduously and successfully avoided. There this is impossible, however, a man tries to shift support from one faction to another as personal advantage or shortterm obligation dictates.

Faction leaders usually search out, or even instigate disputes and make them a context for factional strife. In six of the nine cases involving Indreni residents which were brought before the Panchayat Court, faction leaders supported opposing litigants. The 
motives are often personal gain for the faction leaders and their core adherents, who charge for their various 'services', such as preparing petitions, and hope to share in the proceeds of any victory. Faction leaders themselves are quick to point this out, at least of their opposition. Thus, when a Iimbu brought a petition against one faction leader the latter, in his counter-petition, noted that the Iimbu was being 'corried. (boknu) by the opposing faction leader whose 'tactics are to seels out two persons who are quarrelling and incite one side; and by this he hopes to gain something.' Support may be offered gratuitously only when failure to do so could result in economic or political loss to one faction or, alternatively, gain for its rival.

To what extent are disputes involving Indreni Iimbus absorbed by factional rivalries? The bulk of cases in which Limbus are the disputants concern matters from which little profit is to be grined. Ihis is to be expected because of the poverty of most Indreni Iimbu households. But when a Limbu, especially one who is poor and illiterate, becomes implicated in a dispute where the stakes are high, allies with the necessary contacts, knowledge of law and court procedure are required to ensure any chance of success. To refuse the support 
of a faction in any important dispute would be to court defeat and financial 1oss. Major disputes are thus fed into the existing fectional cleavage.

The process is best illustrated by documenting a dispute over kipat land which has been snouldering for almost a half century and which has exercised two generations of faction leaders.

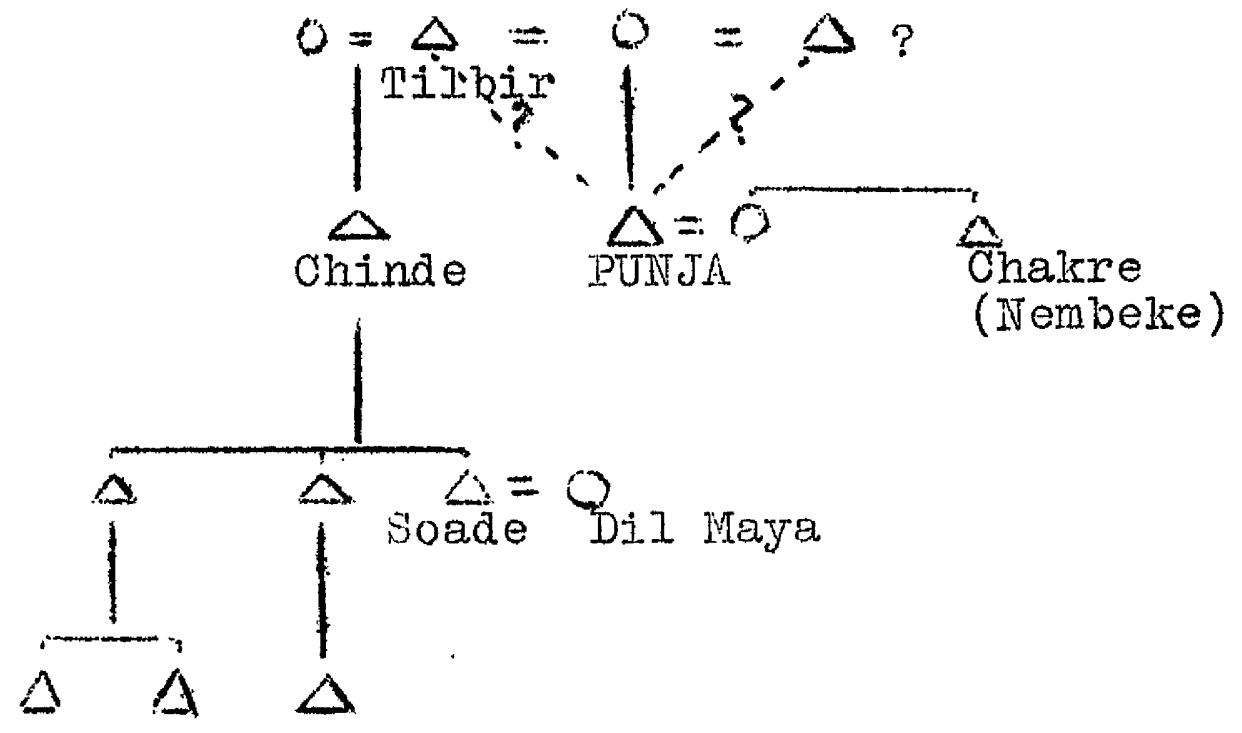

HIMLA

Fig. 10

Following the death in 1922 of lilbir, a Kambo of Chitok, Chinde, his son by his finst wife and Chinde's own three sons opposed the right of Punja to inherit a portion of Tilbir's lands. Although punja's mother had become 'Milbix's second wife, it was widely believed that the woman had come to the Cluster in early pregnancy, 
and that Tilbir was not in fact Punja's genitor. Chinde and his sons were successful in their dispute and so, without edequate means to get a living, Punja migrated to sssam in 1923, where he worked on a tea plantation. He continued to return on occasion to the Cluster, since he had married the sister of Chakre, a Nembeke of Dorumba.

On one of his visits in 1945, he was approached by Ram Chandra, who was at the time leading a faction against his brother Warad Muni, and urged to prefer charges against the latter for illegally encroaching on kipat land ${ }^{1}$. Punje realized that if he could prove the case against the Brahmin, then he might finally get the Iands he had been denied as a young man. Moreover, there would be no-one to contest his right since by 1945 the sons of his half-brother Chinde had died, as had all their sons but one, Himal, who was in any case in India. at the tine. Of all those with rights to lilbir's lands, only Dil Meya, the wife of Chinde's youngest son boade, wes resident in the Cluster, and she was old and sick. In any case, Ram Chandro pointed out, Dil Maye would not

1. See Fig. 8, p. 349. According to informants, Ram Chandra probably knew that Punja had returned from issam with Rs 500 in savings and hoped to get some of this money for preparing the case. 
stand in his way since she had herself been victimized by Narad Muni on severol occasions. Ram Chendra was certain that Punja could win his case, and orfered to prepere the necessary documents.

In his petition to the court, Punja argued:

When I came back (from Assam) I found that my old house, and the house of my brother's sons were no longer there. And there was a large house and there was Narad Muni. I said to him: "what is the matter that you have built a house on our kipat, ond who gave it to you? You are a wicked person." Then I went to $\mathrm{D}_{\mathrm{i} I}$ Maya and asked her.. She said that Narad Muni had driven away all the descendants of Chinde by his treachery. Narad lini, she said, called her time and again to sign papers which he then displayed to prove that the land was raikar and not kipat. Dil Maya had been afroid to refuse so great a man and anyway she is simple, so she signed.'

Narad Muni's reply to the accusation was brief. He challenged the plaintiff to show that any of the transactions he hac engeged in over kipot wos illogal. $\mathrm{H}_{e}$ also brought up the fact of Punja's uncertain parentage and stressed that since Punja hod not received an inheritance of kipat land he hod no business inquiring about the lands. Tarad Muni then spent the greater part 
of his defence attacing iam Chandra and Tunka Noth who was at this time alinged with his eldest brother. He accused them of bringing Punja back to the cluster just to bring a case against him. They seek to destroy my property, and when they are through, they will send Punja back to Assam.'

Beside this explicit statement of the manner in which faction leaders instigate disputes, the alignment of support behind each faction leader throws some light on the pattern of faction formation. Ram Chandra recruited his support for Punja on three bases. Whe first washostility to Narad Muni. A father and son of the same Kambo lineage had recently quarrelled with Narad Muni and could be counted on to support a grievance against the latter. It should be noted, hovever, that the two were from an 'adopted' line and so had no claim on Milbir's Iands. Consequently, Punja represented no threat to their own interests. A second basis was affinal ties. Three Nembeke men, among then the brother of Punja's wife, lent their support to the faction leader for the sake, as one put it, 'of our sister'. Thirdly, and to an extent this criterion subsumed the other two, wos the feeling of hostility shared by all kipat-owning Limbus towerds landholders of other castes. The kinds 
of accusations thrown at lioncd liuni by Ram Chandro and Tunka Nath through the mouth of Punje, echoed the common Iimbu experience. On this basis four Chongbung elders, one of them a much respected Subba, joined in support of Rem Chandra's faction.

Norad luni recruited the kind of support which was meant to achieve two main purposes. The first was to attest to his status as a Notable, and mutatis mutandis his reputation as an honest men who accomplished his ends b.y legal means elone. This required several 'character' witnesses, whose own reputations were immaculate. To this end eleven Notables were recruited from every corner of the Village area. Three were affines, while another six, all Brahmins and Jaisis, were themselves londholders of kipat and undoubtedly saw in this case the threat of a precedent which could affect their own economic positions.

Of perhaps greater importance was the necessity for Marad Muni to present his opponents with a denial of Punja's right to kipat, and this could best be effected by recruiting the support of Himal, who was at the time working in India. The latter was sent for and brought to the Cluster where he confirmed the denial of Funja's rights to kipat, and hence protected his own inheritance. On the basis of this latter evidence, and 
the lack of firm proof to back up Ran Chondra's allegations of dishonesty, the case was decided in favour of Narod Iuni.

fnother dispute over the same lands erupted in 1964, shortly after Himal's resettlement in the cluster after a long residence in India. To build a house and re-establjsh an estote in Chitok, Himal required capital, only some of which he could supply from savings accumulated auring his residence abroad. He proceeded to raise the money by taking interest-free loans (bard) from those to whom his lands had been pledged and adding the amount of the loan to the initial mortgage capital. The kipat lands of Tilbir which Narad Muni had taken under mortgage had been 'inherited' after his death by his son Rungalal. When Himal came to request bard from Rungalal, the latter refused. it first Himal sought to transfer landholding rights from Rungelal to someone else willing to take these lands under mortgage. But the mortgage copital was out of proportion to the value of the lands, and Himal could find no takers ${ }^{1}$. In a rage, Himal requested the support of Tunka Nath, who suggested

1. Informants, including Rungalal, agree that the figures on the documents did not correspond with the amounts actually paid by Narad Muni. 
a re-opening of the case which had defeated Himal's classificatory Grandfather, Punja. Tunka Vath welcomed the opportunity to involve his brother's son in expensive litigation since the latter had recently been making some embarassing accusations about Tunka Nath to Government officials and furthermore, had established good relations with the opposing raction of Bishnu Prasad.

The matter was brought to court but before a decision could be reached several influentiol men in the district, all resident outside the Village area, succeeded in convincing both disputants that by becoming involved in factional strife, they were courting financial disaster. Subsequently, a compromise was reached out of court - and against the wishes of the faction leaders - which enabled Himal to repossess some of his lands.

This case indicates how attachment to faction leaders is temporary and lasts only as long as there is advantage to be gained. A Kambo men who had supported Rom Chandro end Tunke Wath in the earlier djspute, found himself urging mediation in this one because of dual ties to both Himol, as classificatory brother, and next door neighbour and to Rungalal, as tenant on the la tter's land. The case also shows that it is possible to transfer 
alignments from one faction leader to another. Himal, for exanple, first allied himself with Narad Muni against Ram Chandra and Tunka Nath who were supporting his classificatory grandfother runja and later joined forces with Tunka Math against the son of Narad Muni. The basis for alignment in both instances was Himal's own interests.

The great majority of Jimbus are able to avoid involvement in factions. The sanctions which a faction leader can bring to bear on those whose support he solicits are mitigated by several factors. One is the nature of the land system which, as I pointed out in Chapter $V$, enables Limbus to manipulete land rights and so retein measure of economic and political independence. Thus the 24 Iimbu households which are linked by ties of mortgage or loan credit or tenancy to faction leaders and their core adherents are not conspicuous supporters of factions. Another factor is the nature of homestead ond settlement dispersion ${ }^{1}$. The inhobitonts of Bharapa and ingbung, in particulas, seldon have occasion to meet faction leaders and so are easily able to avoid becoming involved. It is not surprising that the few

1. Residence patterns also bear on faction formation in Indian settlements in Fiji. See Mayer, 1957, p.324. 
Iimbus who on occasion have eupported factions have been resident in Chitok and Dorumba where raction leaders and their core adherents reside. But important as land tenure and environmental factors may be in explaining the ease with which Iimbus can opt out of factional strife, they are peripheral to a third factor: the nature of the political arena. By this I mean the conterts within which factional struggles are waged. By engaging in disputes, their own, and those of others, faction leaders compete for economic prizes as well as power and influence. To wage disputes, supporters are of course essential, but their effectiveness is not in numbers. As I have shown, faction leaders solicit core adherents who possess specific qualities which can be utilised in the furtherence of their interests in disputes. Similarly, other supporters are mobilized to lend credence to an argument, act as witness to an event, sign documents or attest to firmness of character.

There is no context, however, in which the numerical strength of a faction is relevant. Although physical assault may lead to or result from factional strife, it is confined to two or three individuals, and does not lead to large-scale violence between foctions. In brief, leaders do not attempt to employ 
coercive force as a meons of achieving their ends, a practice which if rollowed could lea to the importance of sheer numbers as a neasure of faction strength. Both Myer and Benedict suggest that an emphasis on numbers might result from the establishment of an arena, defined by statute, within which elections for office can be held . The inclusion of the Indreni settlements within an administrative Village and the creation of a statutory Panchayat Committee has provided a new context for factional activity, but has not, as yet, brought ebout a concentration on numbers. The Panchoyat Committees esteblished in 1953 and again in 1962 didnot, strictly speaking, absorb the existing factional conflicts. The first Comnittee administered an area and a population considerably larger than that within which any faction leacer could exert his influence effectively. Also, the purpose and authority of the penchayot system could not be readily understood at the time of its inception. It was, and to an extent still is perceived as an justrument of Govemment, created not to innovate improvement schemes, but to implenent the instructions of district and Central authorities. The appointment by the Govornment of a

1. Hoyer, 1957, p. 322 and Benedict, 1957, p. 340 . 
president to oversee the day-to-day worlings of the first Panchayat Comittee further served to prevent the use of the Committee as an arena for factilonal dispute. The man chosen to fill the position was a Brahmin Pondit highly respected for his learning and impartiality in mediating quarcels. He and the vicepresident, another Brahmin of similar status, were largely responsible for the formation of the nine man Committee, although in theory the choice was that of the adult population. One faction leader, Tunke Nath, was chosen to be a nember of the executive, but being only one Notable among many on the Committee, most of whom were neutral to any faction, he had little opportunity to transform the Committee into an instrument for strengthening his faction.

Circumstances connected with the establishment of a new Panchayat system in 1962 changed the attitude of faction leaders to the Committee. For one thing, the area under its jurisdiction came withinthe purview of their own circunference of iniluence. Secondly, the post of Govermment appointed president was abolished so that the choice of the Committee would be entirely an intemal natter. Thirdly, those who had controlled the previous Committee were either outside the new Village, 
too old to assume the responsibilities of running the Committee, or refused to participete on the grounds that the responsibilities were not matched by commensurate gains. All these factors weighed on Bishnu Prasad's decision to represent his ward composed almost entirely of households in Bharapa and Chitok. No attempt was made by Tunke Nath directly to oppose the candidacy of his brother. Informants I asked about this stressed the fact that Tunka Nath had been on the previous Comittee and so 'had his chance'. Also, the idea that elections should be held to choose a representative was felt to be bad as they would 'show our querrels'1. Tunka Nath, however, tried to persuade one of the ex-army pensioners to join the Committee, knowing thot if he did Bishnu Prasad would stand down. Although there was some feeling in the word that it should be represented by a Limbu, the ex-servicemen refused and deferred in favour of Bishnu Prasad. Once it was known that the latter wos to enter the Committee it was a foregone conclusion that he would be its Chairman. He was able to ensure that the majority of representatives were men of no consequence, and that they were either his own supporters or men not attached to any faction. The notion that the Comitiee

1. No elections were held in any of the wards. 
should reflect a crosimsection of the various castes resident in the Village Iimited the choice somewhet. It was felt, for exenple, thot at least one representative should be a Iimbu. Since Bishnu Prasad was himself from a Iirbu-domineted ward, Jehare was chosen to represent the ward which includes Dorumba. This was the only successful attempt by Tunke Nath's faction to place one of their adherents on the Comittee.

When the Committee came to elect its Chairman, Jahare suggested that he might seek the office. It was thought that a contest would leove bad feelings and Jahare, realizing that he would have no support in any case, made no attempt to carry out his threat. Bishnu Erasad was then chosen by acclamation. Shortly thereafter, Jahare became involved in a court case with the district administration - which, he alleged, was instigated by Bishnu Prosad - and ceased attending Committee meetings. He was replaced by enother Hembeke of Dorumba, considered an occasional supporter of Bhagi Rath and Bishnu Frasad in their factional disputes.

Thus Bishnu Prasod succeeded in packing the Panchayat Committee with men who would not oppose his will and who are, by and large, ready to rubber stamp his actions. But the fact thot one foction leader monopolizes the statutory authorjty which resides in the 
Committee does not preclude the existence of opposition on the level of policy making. This is because decisions are arrived at by consensus of a body wider than the Panchayat Committee.

Neetings are seldom held, and important issues never broached, without the participation of at least some Notables who are not in fact members of the nineman Comittee. Except during the rainy season, meetings are held regularly, so that anyone interested in attending knows where and when to come. Although the Committee has the authority to initiate a wide renge of actions, when an importent decision is to be taken, invitations are sent to influential men in the area requesting them to be present. Committee deliberations thereby take on the character of informal gatherings of Motobles. This 'comprehensive cominttee', as Mayer colls a similar body in Ramkheri, is not given formal recognition and has no fixed membership or existence outside the framework of Committee decisionmalring 1 . It is also to be distinguished from a formally constituted sub-comittee, with on executive and determinate nembership which may be estoblished to deal with special

1. Hayer, 1960, pp. 116ff. The 'Comprehensive Committee' in Ramlheri, however, was a more formal body, itsele having officens. 
projects. Thus, for exomple, when it was decided to buila a Fanchayat Fouse, a sub-committee consisting of twenty-four of the wealthiest residents in the Village area wos set up to collect monies.

The Fanchayat Committee, then, is subsumed by a plenary body composed of men who are traditional leaders. Members of the former, other than Bishnu Prasad and one or two other articulate persons, voice no opinions in the presence of these men of influence. In such a setting, members of the faction opposed to Bishnu Prasad - who attend meetings regularly - participate in decision-making and are able, on the whole, to neutralize the possible advantages Bishnu Prasad could denive from control of the Panchayat Comittee. Ihere is room for factional hostility to be expressed in opposing views of various Committee projects, but a midale way can be saught under the guise of working for 'national development'. liatters are never taken to a vote. Discussions which cannot be resolved at one meeting, are carried over to the next until a suitable compromise is reached ${ }^{1}$. Often a decision taken at one

1. Comenting on the nature of consensus in a comittee, Boiley states: '....everyone knows that if the decision is not the result of an agreed compromise, then it cannot be jmplemented.' (1965, p.8). 
meeting is counternanded at the next, when news of the decision reaches the ears of liotables who were not present at the previous meeting. Minutes are kept, but they mention only those in attendance, and what the Committee eventually decided.

Ihus the established procedure of seeking consensus achieves the dual purpose of containing factional strife and enabling the Committee to carry out its tasks of local government. When the Committee attempts to ignore the wider consultative body on important matters it risks bringing foctional opposition out into the open. This happened when Bishnu Prasad attempted to win the approval of the Village Assembly - which must ratify the Committee's annual budget - for a tax plan which had been prepared without the prior approval of the plenary body. The faction opposing Bishnu Prasad gathered sufficient support to stage a walkout and so broke up the meeting before the required number of signatures could be gathered to legelize the proposal.

There are signs of a growing realization on the part of faction leaders that control of the Committee is an essential prereguisite for building a strong political following. Kothmondu's emphosis on the development of o viable Penchayat system has meant that Government officials at the district level are especially sensitive 
to anything they regerd as an attempt to hanstring the work of the Comittees. Opposition to proposals of the Committee, or to its manner of implementing Government programes, thus tenas to be equated with opposition to the Panchayat system. A faction leader in control of the Committee can increasingly aisregard the traditional methods of achieving consensus and pressure others to conform to his policies under the veiled threat of denunciation as 'opponents' (birodhi) of the Panchayat system. Several men who have been vocal in their disagreement with certain Committee proposals have been called to Ilom Bazaar for a browbeating by various Government officials.

Ultimately, of course, a determined Committee could exercise its statutory powers to take all necessary decisions without reference to a more comprehensive body. Thus, a new coercive weapon has been added to the arsenal of the faction leader entrenched in the Committee, and could lead to a shift in the delicate balance between the two factions. Given the continued development of this trend, it is possible to foresee the Commitee becoming the principal arena for factional strife. In such circumstances, formal election procedures could replace the hitherto consensual methods of choosing 
representatives. It would then follow, logjcelly, that new emphesis would be ploced on the large-scale recruitment of factional following and, altematively, on the need ror residents of the Village area, including Limbus, to take sides to a greater degree than they now need to do. Until such time, however, there is no circumstance in which it is necessary for a faction leader to measure his strength in numericel terms. 


\section{CULUUPE AND KIPAT: \\ THE EXTEEITAL DIIISHSTOL OF PCLITTCS}

In the previous chapter I doscribed certain kinds of political choices open to Inareni Limbus, There is, however, another aspect of the political configuration - which might be termed its 'external dimension' - to be considered. This has to do with the cultural distinctiveness of the Limbus and the manner in which the kipat systern of land tenure is fused with and articulates the culture. ${ }^{I}$ Many Limbus believe that 'kipat' is a term in the Iimbu tongue and, having been granted only to Limbus, is symbolic of their exclusiveness. Thus, 'our social, cultural and religious beliefs, way of life, and administration under the kipat system are completely different from those prevalent in the rest of the country. ${ }^{2}$

Indreni Limbus see themselves as part of a historical cultural unit with a special relationship to land, and which unit is both exclusive and in opposition to the outside. Such a relationship tends to define the nature of Iimbu social contacts outside the immediate area of the Cluster and absorbs them in political activities on behalf of the wider group. Inevitably, their apartness also affects and is affected by relationships both to non-Iimbus

1. For a description of some cultural differences between Iimbus and Brahmiris see chapter I.

2. B.B. Chemjong, 1957 (wuoted in hoC. Regmi, 1965, p.131). 
in the area of the cluster as weil as to other Iimbus within the Indreni settlements.

Ties outside the Area

Ixclusiveness is fostered by the dual regulation of caste endogany and clan exogamy which envelops Indreni Limbus in a widespread web of kin ties beyond the Cluster. These links are strengthened and expanded through a continuous process of interaction demanded by the norms of ininship. For one thing, the custom of visiting during Dasein provides the occasion for a renewal of ties between daughters and sisters who have married out and their natal kinsmen, as well as between the husbands of these women and their affines. During the three years following a marriage, a son-in-law is expected to pay his annual respects to his father-in.law. Since a variety of payments in meat and liquor must be transferred on each visit the couple is accompanied by anything from three to six young mer from the husband's settlement cluster who carry the payments. Such visits, obviously, not only discharge the obligations of kinship but enable fledgling affinal ties to be bolstered. The presence of so large a number of guests also requires the provision of hospitality which absorbs the attentions of a circle of affines wider than members of the bride's househola alone.

Marriage and mourning rites are other important occasions for the renewal of ties. Whe fomer rites, in 
particuiar, bring together large numbers of irinsmen not normally resident in the groom's settlement area. The marriage of a son calls for invitations to be sent to the groom's mother's brother and other close matrilateral kinsmen, to the groom's sisters and their husbands, and to the sisters of the groom's father and their spouses. In addition, the bride is accompanied to the wedding by a number of women from her settlement axea, some of whom may already be related to residents in the settlements of the hosts.

There are also less formal contexts for the maintenance of external kin ties. Visiting among relatives is encouraged and requires little prompting. A man knows he is always welcome at the home of his mother's brother, and often takes the opportunity provided by a slack agrim cultural period to pay a visit. When a woman is ill her father or brother are usually notified and someone from her natal household will be despatched to report on her condition. If the illness is traced to supernatural causes which cannot be treatea by local specialists a ritual expert from the wonen's natal settlement, "who knows her deities" mignt be summoned to treat her.

But kinship provides only one chanrel through which Indreni Limbus establish a widely ramifying range of ties to other iimbus beyond the area of settiement. 1 I. In one sense, any relationship between limbus can be subsumed within a framework of kinship. A superficial inquiry about clen membershlp elables two complete straingers to establish a pseudo-kinship tie. 
Shared culture and the notion of comon identity is another basis. Language forms en instant bridge between all Limbus, just as it provides a barrier which cain be erected at any time between themselves and members of other groups. Language serves to overcome the initial reserve with which any strangers are regarded. Moreover, the situations in which Iimbu strangers, are apt to cone together possess certain structural attributes which contribute to ease the establishment of rapport. For example, the market in Ilam Bazaar provides a regular occasion for Limbus from settlements in the area to come together. Iimbu petty traders tend to occupy one section of the market square and mix little with members of other castes except to engage in fleeting comercial transactions. The social concomitants of market day - renewai or creation of friendships, exchange of gossip, flintation - take place within a geographically and socially distinct area. Limbus frequent certain 'tea stalls' seliing liquor, thus dernonstrating their preference for the company of other Limous and easing communication with those who are unfamiliar.

A number of annual fairs held in various parts of the district bring together large numbers of mainly young Iimbu men aid women. Here again, the pattern of separation is evident. At two such events I witnessed, ettendance was not confined to Limbus, but brought together a large mixed population for as inany as four days at a time. 
In each instance, Iimbus segregated thonselves in one section of the grounds and had virtually no contacts with members of other groups. nihrough the medium of Limbu mixed dances, Indreni resident dispersed easily among the crowds, renewing old and establishing new friendships. Members of other groups who sought to join the dances were not turned away, but neither were they made welcome. Embarrassment at not knowing the dance steps or the language of the songs soon encouraged them to return with theix friends to another area of the fair grounds.

Long distance trading ventures provide another context in which Limbus from the Indreni settlements make contact with others from various parts of Iimbuan. During the mandarin season, in particular, the main road leading to the town of Sanisare in the Terai carries a heavy traffic of porters bringing the fruit from areas to the north. Since the trip takes several days, Limbus make camp at night in one of a number of shops where they can buy beer or liquor and find a place to sleep. Here they pick up the latest gossip and exchange information on prices with those returning from Sanisare. In the tow itseif, they seek out the company of other limbus, share drinks and make up parties to return together to the nills. On their retirn to Ilam Limbus from settlements to the morth of the Cluster are often invited to spend a night in the cluster, where a dancing party is orgarised in their honowr. 
Frierdships created in this way are sustained beyond the portering season all a pattem of mutuat visiting may endure for years, or eventually lead to the formation of affinal Iinks。 1

When Limbus traved Long aistances for any purpose, be it trade or visiting, they invarıably seek out Limbu households or wayside inus run by limbus at which to spend the night. When I trekked for several weeks in parts of Limbuan my Limbu traveliing companion would speed up or delay the dally journey in order to arrive at dusk in an area of limbu settlement so as to be certain we would receive hospitality.

In a variety of ways, then, Indreni jimbus recognise their exclusiveness as a culture group. In a sense, this group is more important than any local community which includes members of other castes. Opposition to the outside is conceptualized not merely in local terms but in the context of wider group membership. When an Indreni man refers to 'we Linbus' he identifies with all Limbus, not orly those in the cluster.

Cultural identity becomes political identity in the context of the confrontation over kipat land. Insofar as the lard terure system is included under the rubric of

1. The persons involved in these friendships do not become ritual brothers (mit) since this would eliminate the prospect of affinal links being created between menbers of their immediate families. 
cuiture, any assault on kipat is seen as a threat to the very existence of the Limbus as a separate unit within Nepal society. The strugste for kipat has therefore provided the framework for common action against those forces threatening Limbu hegenony over their Iands.

Since at least the late 19th century there have

been sporadic attempts to organize opposition among the Limbus to stem the tide of kipat conversions to raikar tenure and to redress the balance of power which weighed heavily against the Subbas as a result of the Government'a kipat policy. There is no indication that any permanent political association to represent limbu interests was ever set up. Instead, ad hoc comittees of Subbas and elders on a district- and even Limbuan-wide level were established from time to time, usualiy to protest against adverse legislation or tine threat of such legislation. Thus, in 1913, when the Government was contemplating the conversion into raikar of all kipat lands in Ilam mortgaged to members of other castes which could not be redeemed within six months, it invited the opinion of the iimbus to this proposal. Hieetings were held in settlements throughout the district and 330 men, most of them Subbas, were delegated to present the Iimbu case to the aistrict officials who were conducting the inquiry. The Government was ajparentiy impressed by the intensity of Limbu opposition to the proposals and withdrew them after receiving vague promises - which it must have lnown could not be fulfilied - that hipat land 
would in future not be mortgaged to members of other castes. Disparities between the Legal Code and special regulations enacted to deal witin the problems of imbuan led to the formation of another ad hoc comnittee of subbas in 1946. Several Ilam headmen, including one from the cluster, were invited to join the committee, consisting of fortyfive nembers, to make recommendations for the avoidance of contradictory rules pertaining to kipat land. The Subbas pointed out that in cases where the law of the State conflicts with laws relevant only to kipat the courts tended to ignore the latter. They urged that a subba familiar with the 'customary rules' be attached to the court as a consultant, since the officers of the court were not always aware that differences in the Laws did exist. 1 They also urged that a special law be written for Iimbus. 2 None of the latter suggestions was adopted but the authorities did issue an order (sarad) reaffirming many of the regulations issued in the past and promising to resolve some of the discrepancies in the law. Whether any concrete action was in fact contemplated is doubtful since similar promises had been made in the past. shortiy after the issuance of the order the Government released its plans for a panchayat system which the subbas regarded as inimical to their interests. Before the plan could be effected, however, the Rana Goverument was swept out of office. 1. The "clistomary ruies" they spoke of were in fact the special regulations dealing with the problems of limbuan, which were introduced by the covermment over the years.

2. This was not as bizarre as j.t might seen, since the old Iaw Code had a special section aplying to Newars. 
In the interval of several nonths between the collapse of Rana authority and the flrm establishment of the new Government the Jimbus sought to organze themselves for more effective political action. A meeting (chumlung) was held to which representatives from ald areas of Limbuan were invited. The more moderate voices felt that the meeting should limit its purpose to the formulation of proposals for presentation to the incoming Government. They sought only firm guarantees for the maintenance of the kipat system and a greater voice for Limbus in the affairs of Limbuar. This was to be assured by the appointment of Iimbus to senior posts in the administrative bodies in the area.

More extreme elements, however, taking cognizance of the temporary hiatus of power in the region, denanded the establishment of an independent Iimbu state. ${ }^{1}$

SeveraI Indreni subbas who were present at the meeting stated that these elements spoke of storming the administrative offices in the Limbuan districts and establishing independence forthwith. Some of those in attendance are even alleged to have set about deszgning a Jimbu flag. In one area of jimbuan where relations between Limbus and local Brahmins had been particularly strained there were some outbreaks of violeice, and it appears that a number of Brahnins were killed and much property destroyed. That

1.One author claims that in Januar' 1951 a "Frec Kirat State" was actually declared; mone of my informants could confirm this ard I have seen no documents to back up this statement. See Driver, 1963, p.85. 
these acts of violence were in any way connected with the meeting is very doubtfus.

There is 1 o evidence to suggest that even the mild proposals suggested by those responsible for oxganizing the gathering ever got beyond the talking stage. "They drank and boasted of what they were going to do' was how one Limbu who had been present summed up the meeting. In Ilan, following the transfer of power which was swift and uneventfut, a number of subbas sought to test the attitude of the new regime towards kipat by drawing up a list of demands. It is worthwhile listing them here since they are, by and large, typical of those presented to the authorlties over the years. They illustrate how kipat tenure has been the focal issue in all these rather diffuse and on the whole abortive attempts at political pressure. There were seven proposals prepared by 195 delegates including three subbas and two elders from the Indreni settlements - from thirty-five settlement clusters throughout Ilam. Two Chongbung Subbas in the Indreni Cluster were in the special committee of three chosen to present these demands to the district Governor. The proposals were as follows:

1. Most of our kipat lands have been pledged to landholders. One-third of these lands should be returned to their Limbu owners (without repaynent of the mortgage capital).

2. At present, a kipat owner must repay the mortgage in full before he can ropossess his Land. Landowners should be allowed to repay nortgages piecemeal and repossess their lands piecemeal. 
3. Any raikar land purchased by a limbu should be converted to kipat tenure aid the tax on the Iand included within the household tax alreaciy paid by the kipat owner.

4. At present, when a new household is registered at the time of a revenue settlement, it must pay a fixed tax assessinent. But the number. of households increase while the amount of tax renains the same. Henceforth, the amount of tax paid by newly registered households separating from one main household should not exceed in total that paid previously by the main household.

5. At present, Tharis subnit taxes collected from their dependents directly to the treasury office. Henceforth, they should be made to subinit these taxes to the Subbas who would then pass thern on to the office.

6. The Subba's court (amal) should be given the right to hear disputes (and to collect fines).

7. If these proposals are introduced we will accept responsibility for the maintenance of law and order in our areas.

8. Limbus are 'backward'. Something should be done to bring them up to the level of the other castes.

Seven of the eight proposals are concerned directly with kipat land ard the special position of the subbas as a consequence of their traditional relationship to that land. Numbers $1-3$ suggest ways of altering the balince of control of land, while the fourth proposal seeks to alleviate the tax burdeis on the land. Numbers 5 - 7 aim to re-establish the power of the subbas which grew out of their initial roles as custodians of kipat, as grantors of estates to ilmigrant settlers and as the principal

channels of administration at the settlement level. Proposals 6 and 7 are also veiled attempts to forestall the establishment of Panchayats in the area, which were regarded as additional threats to the few remaining prenogatives of 
the Subbas. The last proposal is meant to refer to the specific educationat needs of the Himbus and, nore generally, reminds the Goverment that Limbus are a distinctive group requiring special consideration.

In Ilam, this was the last organized atternpt to bring pressure on the Goveriment to alter its kipat policy, although attenpts to organize opinion on a Limbuan-wide basis continued. When a series of demands similar to those prepared by ILam Subbas were presented to King Tribhuvan in 1951, a statement was issued reminding the Limbus that east Nepal was inhabited by many castes and that only the wishes of all the people could be taken into account in determining policy. This represented not so much a change in the Government's attitude to kipat as the adoption of a more blunt method of treating limbu demands for special consideration. The Limbus continued to make representations to Kathnandu and at least one more major effort to co-ordinate political action was attempted in 1958. It is significant that of the seven organizers of this meeting, two were Brahmins and another a chetri. This was not merely an attempt to give voice to all sections of the population, as the Goverminent had recomended, but an expression of the interests which rich non-Limbu Landholders of kipat had in maintaining the kipat system. For as providers of mortgase credit, they had access for lengthy periods of time to lands on which the taxes were minimal and at a cost considerably Less than that reuired 
to purchase raikar Iand.

The ouicome, however, was similar to that of previous meetings: proposals were put forward and promises were received that they would be considered.

At the approach of elections in 1959 kipat threatened to become an issue when the Congress Party came out in favour of abolition while another party the Gorkha Parishad, supported its retention. Perhaps it is an indication of the numerical strength of non-iimbu residents in Iimbuan or a reflection of the tactful exclusion of its kipat plank from the Congress campaign in the east that the Congress party won all eight seats it contested in the region. I In any case, the threat of abolition was not implemented even after Congress formed a Government. In December, 1960, after only fifteen months of rule, parliament was dismissed ard the lilonarchy resumed control of the Government. The 'traditional rights and privileges' of the Limbus were again guaranteed by a royal decree, although again this meant no basic alteration of the Government's kipat policy.

For more than half a certury then, Limbus have attempted to protect their interests in land. Their political activity, by and Large, has been unco-ordinated and ill-organized. Their demaids have often been

1. None of the Limbus in tho cluster was aware of the Congress attitude to kipat, and apparentjy did not hear of it from the opposition candzdates. 
unrealistic, occasionally irrelevant and, nore recently at eny rate, far from effective. But by circulating petitions, holdirg mass neetings and seuding delegations to present their views to Goverment, the Limbus have cultivated a widespread awareness of their special position vis a vis the rest of the population. The land tenure systern thus blends with ard adas a structural dimension to the fact of cultural exclusiveness.

\section{Ties Within the Area}

The Subba

The development of a strong Iimbu identity has affected the position of the Subba within the local commnity. I showed earliex how the Subba's traditional role as custodian of ineage land gave him certain powers over his lineage mates. Additional authority, of course, devolved on him in his roleas tax-collector and representative of the Goverument. In a sense, the Subba expressed not only the unity of the lineage, but the importance of this group in the ownership and allocation of land resources. It spunity was bolstered by ritual functions vested in the subba and his position was recognized by nembers of the lineage through the systen of tributary payments.

His role has changed as a result of two linked developments. First of ald, the land shortages which developed at the end of the 19 th century brought about 
an emphasis on the rights of tine household against those of the lineage. As the inportance of the household, based on elenentary-type families, increased, the lineage structure ceased to function as an economic or political unit. The role of the Subba as head of a land-owning unit correspondingly declined. Secondly, the collapse of the leadership hierarchy, evolved through the system of land grants to immigrant settlers, and the subsequent usurpation of many of the Subba's powers by the Tharis and the Goverment (including, more recently, the Panchayat bodies) further eroded his traditional powers as Government representative to the Iineage.

Yet despite the removal of the bases of his power, the Subba remains a figure of importance in the communty. 1 This is especially evident during the festival of Dasein, when tributary payments are made and the Subba discharges certain ritual functions. Although Subbas no longer have the authority to exact tribute, few Iimbus make any attempt to avoid what they regard as obligations: In October, 1964, approximately $80 \%$ of kipat-owning Himbus visited their Subbas auring Dasein, bringing gifts of $\perp i q u o r$, meat and Rs.1.60 which latter, it was explained, roplaced the traditional labour exaction to which Subbas were entitled. In one presentation I witnessed, the Subba sat in the midale of his room and as

1. Headmanship apparently stili carries sufficient prestige to have brought about a dispute over succession to the title ariong two Nembeke men. See pp. $357 \mathrm{ff}$. 
each dependent approached, the gifts were placed on the floor beside the headnan, following which the dependent bowed to the other's feet and received a tika on the forehead. The liquor was then shared anong those assembled. Only members of Chongbung Lineage (3) did not honour their Subba, since the latter was still a young man in his late teens. Even so, some gave their tribute to one of the other Chongbung Subbas, explaining that it was necessary to honour a Subba, and that it mattered little if he was the headman of another lineage.

This same attitude manifested itself on the ninth day (naumi) of the Dasein festival. This was the occasion for a ritual display of the subba's diacritical trappings of power as weil as of his generosity. Since each subba is believed to hold his title by direct appointment of the king of Nepal, he is entitled to surround himself with the accoutrements of office. These are a sacrificial post which stands in a fixed spot near the homestead of the subba and which attests to his 'rule' in the area; a drum, traditionaliy beaten to warr people in the area of impending dangor; and a sword, which symbolized the subba's coucern for the defence of his followers.

On the mornizg of nauni each subia combined the ritual display of office with the practice of blood sacrifice. Following the rutuas, the subbas gave tika 
to those atterding and the meat, provided by the subba himself, was then cooked and eaten.

of particular interest was the pattern of attendance at these rituals. Jineage was ondy an incidental criterion, despite the fact that the Subba is traditionally associated with a lineage. For exampie, a number of Chongbungs and nembers of non-kipat-owning groups from neighbouring homesteads attended the rite at the sacrificial post of the Kambo Subba in Chitok and shared in the feast. One of his Lineage mates from Bharapa also attended, but several others resident in Dorumba attended the ritual of the Nembeke Subba in that settiement. No division of followers took place at rituals conducted by three Chongbung Subbas whose sacrificlal posts were situated in Bharapa and Angbung. There the three rituals were held consecutively, enabling all participants, some of whom came from Chitok and some of whom were not owners of kipat Iand, to move fron one rite to the next, thus honouring all three Subbas equaliy.

By cutting across lineage bouldaries, these rituals stress the point that the subbas have come to syrabolize a wider collectivity. In other words, there is a shift in emphasis away from the subba as representative of a Iineage towaras the notion of him as a symbol 
of the unity of the Local cosmunity. 1

The nature of his role energes more clearly in the context of the Himbu struggle to preserve the kipat system. I pointed out how the subbas were in the forefront of the activity to protect uimbu interests in land. Locally, this has added to the prestige of the headmen as a category, ever though of the seven Subbas in the Cluster, only two have engaged in these activities on a aistrict or Limbuan-wide level. The subba is also seen as the embodiment of limbu tradition and exclusiveness, and as a force of conservatism against the likelihood of change. Since 1952, subbas have led the opposition to the establishmert of a Panchayat system. When the district authorities invited the subbas to organize support for Panchayats anong their depondents, several Indreni Subbas were instrumental in the preparation of a letter calling on the Government to witharaw its intentions to establish such a system. Indeed, Subbas are often given credit for the fact that the Panchayats were abolished in 1956.

During the time I spent in the field the issue which most exercised their antagonism to the Panchayat was a project to erect a building for the Panchayat

1. Among a number of African peoples, the chiof performs a similar function. Among some, as ior example, the Mambwe, he also retains his traditıonal rights to allocate Land. Cf. W. Watsoil, 1958. 
Committee. About $80 \%$ of the flinancing was to be raised from Village residents. For the purpose of apportioning contributions, nembers of the Cormittee placed everyone in one of four categories on the basis of impressionistic (though fairly accurate) assessments of wealth. Although about $90 \%$ of Limbu houscholds were placed in the two lowest categories (contributions of Rs. 20 and Rs. 6) the consensus was that the level of contributions was too high. For morths, whenever Limbus gathered in some numbers, the topic of conversation turned innediately to the Panchayat Comittee and the financial burden it had imposed. Rescntmont at having to pay what for most amounted to a corsiderable sum was directed mainly at the Panchayat systom as such. The Comittee was seen to have replaced what for the Limbus was a far superior system based on the traditional ties between Subba and dependent. At one funeral rite, ais elder, (who had been placed in the Rs 20 category) spoke at some leisgth about how the

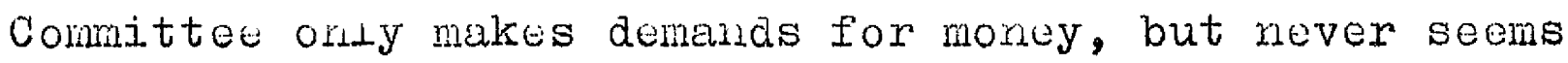
to accomplish anything. "What kind of Comnittee is this which takes monies from tine Govermant - (which contributed 20\% of the costs) - ard fron the people, but shows nothing for it?' Hu wert on to compare the Comittee to the Subbas, 'who did everything for the people and who returncd whetever they trok.' Tho aldusion was to the traditional balence of rights and obligations which 
characterized the subba's relatious with his dependents. By implication, he accused the Colinittee of emphasizing only its rights at the expense of its obligations. ${ }^{\perp}$

Brahriins, buciuse of their close identification in Limbu eyes with the Comittee, come in for a fair share of the genural hostility to Panchayats. ${ }^{2}$ Protests were voiced about the Lack of consultation at the time everyone was categorized for the assignment of contributions. The Lirabus vere not satisfied with the explanation that tho ward represcintatives had made the assigments. Residents of the two wards in which Limbus are a rajority and which are both represented by Brahmins complained bitterly that they had played no part in choosing their representatives and did not feel that their best interests wore being served by these men. Following a threat by the Committee that the police would be called in if contributions wero not forthcoming, a meeting of Angbung residents was held. One of the subbas suggested bringing a complaint to the Goverment against the Brahmins 'who because they are so rich aid educated run the Comattee and think they can do anything tiney waxt to do.' There was much talk

1. To be fiar, not only the Himbus complained about having to pay. But mumbers of other groups did not express their aiger in quite the same terms.

2. Five of the prescut Comittee members cre Brahnins, three of thor, including the chalrmen, are meribers of an extended famly. See betow for a discussion of Limbu-Brahuin relations. 
of refusing to pay, and of fighting the mattur in court, or, if lucessary, resisting with force.

In the face of the Govermont-backed authority of the Paichayat Comittee, the iimbus knew from the start that resistance would lead nowhere. When I left the field the building was nearing completion and the rate of payment of Himbu contributions was keeping pace with that of the rest of the Village population. The occasion had provided an opportunity to express hostility to the Committee regarded both as the instrument of the Brahmins and a usurper of the powers of the Subba. The emotional flare-up over contributions to erect a building for the Committee thus served to bring together the local community behind the rigure of the Subba who, in turn, symbolizes its unity.

Iimbu-Brahrin Relations

The identification of Brahmins with the Panchayat Comittee stresses that local relationships with menbers of other castes has becn affected by the wider question of limbu opjosition to the outside. It ls now tine to exanine the nature of these ties. on the level of local interaction limbu antagonism is darected primarily against the Brahnins. This lis mainly because local Brahnins have derıved most advantages from the Government's kipat jolicy and, et the expense of the jimbus, have 
becone the most powercul group in tho area. It seens necessary to ash why Bramuin were able to benefit more than other noul-imbus?

Three factors would seem to suggest possible explanstions: numbers, literacy ard Government service. In the area under the jurisdiction of the ranchayat Comittee the Brahmins constitute the single largest caste group with $32.5 \%$ of the population. They are $39.8 \%$ of the non-Limbu population in the Village, and $50.4 \%$ of this category within the ixareil settlements. Thus, by weight of numbers alone Brahmins would be expected to be favoured by any Legisiation designed to bencfit nonLimbus.

Literacy is another factor which has worked to their advantage. Host Brahmins were able to acquire the ability to read ard write despite the almost total lack of formal educational facisities in Ilan until the 1940s. Traditionally, young Branmins were instructed by religious teachers individual $\perp$, or attended informal "schools" (pathshala) organized by learred men in the arca where, through the modiun of Sanskrit, they becane liturate in the Devanagari script. Some of the wealthiex men sent their sons to Benares, Darjeeling or Kathnaldu for schooling. A few Indreni himbus were able to acquire Literacy through friendships established with Brahmin tutoris, but on the whole, until they begen serving in 
the arny, Iimbus renained illiterate. In consequence, they were forced to redy on Brahmins, as were most other groups, to prepare the documents required at the trme of property division, land transactions, disputes, etc. And, as I have nentioned, only a few Brahnins with a high degree of Iiteracy could manage the sixills required in draftirg petitions to various branches of the administration and the courts.

Ability to read and write was also one of the qualities demanded for Goverrnent service. Although the top posts in the district adninistration teuded to be filled by Kathmandu appointees, some senior and most intermediate ard junior positions were open to local candidates. As a result, Brahnins were able to play a key role in the local administration in Ilam. Government service was actively sought by ambitzous Brahmins from settlements in the vicinity of llam Bazaar. Wealthy men were able to widen their range of contacts and to use their positions to secure for themselves and their followers some personal advartage. For men without means, service in the administration was perhaps the only avenue of advancement and on their return to their settlements they were able to utilize the prestige and more concrete benefits of service to enharce their wealth and status. Some of the most promine.t Brahnin families in the Village have a history of Govement service. The father of the 
faction luaders for uxaple, was a selior officlal in the administretıon for main yecins.

These factors, thes, undoubtody provided the wherewithal for Brahnilis to attaln ascendancy in the politico-economic Life of the area. Largety because local Brahmins were the chief beneficiarles of the Goverment's kipat policy, they are regarded by Indrexi limbus as the prime instruments of that poticy.

Following the establishment of kathmandu's authority in Ilam members of various nor-Limbu groups were encouraged by the Government to settle and take up land. During the first century following the pacification of the district thero was adequate land for settlement and cultivation. In these circumstances the limbus accepted the Imnigints, the majority of whom were Brahmins, ais made land grants to them. Graduatiy, in a number of ways catalogued in Chapter III nore and more lands came into the hands of Brahnin immigrant settlens. By the last part of the I9th century, land pressures were beginiling to be felt and there was a dearth of barren land to bring under cultivation. It was at this time that Kathmandu converted kipat graits already made to non-Limbu settlers into raikar and introduced a number of policies making it possible for nembers of othor castes to bring kipat lands under raikar tenure. 
The Holdings greinted by Inäreni subbas have ail

been converted to raikar and the jubbas no Longer have any rights whatsoever in these Lends. ${ }^{2}$ iimbuis are adamant about what they allege to be the deception perpetrated on the subbas by theix erstwhile dependents, the Tharis, whom they accuse of responsibility for conversion of the Holdings. Since the great najority $(70.4 \%)$ of recipients of land grants given by Indreni Subbas were Brahnins, the Latter receive the brunt of Limbu hostility. When discussing Brahnin 'treachery' (jal) one Limbu informent sumarized his views in the following rhyme.

Tip of the sugar cane, root of the radish, Keeping a servait is the ruin of a house, Left in the barn he drinks the crean, Left in the hore, he takes your spouse.

The Brahmin is thus regarded as an 'ungrateful servant" who, trusted to watch over tine land he was granted, 'stole' it by converting it to raikar. The fact that the Goverument provided the Legislation necessary to enable the Brahmins to effect the transfer is disregarded in the face-to-face situation.

In a number of othor ways, Brabinins in the area of the Cluster took advantage of regulations to improve their econonic position at the expense of the Limbus. A Governent rining that possession of kipat laind had to be supported by documentary evidesce of title proved Lucrative ground for ambitious noi-Limbus. Since the Goverment 1. See the case of Jahare and the Jaisi Thari, pp. $307 \mathrm{ff}$. 
did not possess the a peratus to enforce this ruling, it relied on, indeed encouraged, litornants (polaha) to bring these matters to the attention of the local authorities. The reward to these informants for successful prosecutions of lard 'conceatment' was the land itself. Immigrant settlers were thereby encouraged to contest the flimsy evidence of ownership rights held by their limbu neighbours. Residents of the Indreni settlements did not escape these challenges to their rights to occupy kipat land in the cluster.

In 1913, for example, a Brahmin from a settiement one mile south of Angbung petitioned in court in Ilan to be awarded about 4,000 units of paddy land registered as kipat in the names of five menbers of Chongbung lineage (4). He argued that the Limbus did not possess proper documentary evidence of ownership rights to these Lands. The defendants eited a number of written assurances given by the Goverment that uncultivated lands converted irto paddy fields and brought under cultivation by the Limbus could be held as kipat. They also produced copies of several docunents attesting to Chongbung rights to cultivate their ancestrat Lands as kipat. But the court agreed with the petitioner that the docunents presented as evidence by the Limbus ald not in fact prove sufficient title since for - one thing there was no mention of boundaries and, for another, they were granted by local officials and not by the Crown. The meinbers of the Chongbung lineage were 
fined Rs 1570 for talse reglstration, and the Lands, reprosenting approximatedy orie half of the total Lineage paddy area, were converted into raikar tenure and given to the Brahmin.

Another facet of the relations between the two groups concerns the fact that Limbus must rely mainly on Brahnins for the buik of their mortgage credit. This has given rise to the notion, backed to an extent by readily cited experiences, that aLI Brahnin Landholders engage in sharp practices to the detriment of the. Inimbu kipat-owners. For example, at the turn of the century kipat landholders were, for the first time, required to share in the tax burden of those Limbu kipat-owners whose lands they had taken under pledge. Shortly after the regulation was introduced the Limbus begen to complain that many Landholders were attempting to claim ownership of the lands on the grounds of having paid the required tax share (dainasahi). The Goveriment was obliged to assure the Limbus and the landholders belonging to other castes that it did not intend this to happen.

Arother ruse was employed in land pledging transactions whereby the landholder would provide a small anount

1. Another Brahinin from the seme settleirent, encouraged by this case, brought a petition in 1929 against all the Subbas of. Ilam, contesting their rjghts to hold ripet. The case was throwin out on the grounds that the petitioner did not specify which Lands were being cultivated as kipat. 
of nortgage capitai cind after obtainino the signature or, more likeiy, thumbrint - of the kipat-owner, would then acia 'a few zeros' to the amount, thus making it impossible for the kipat-owner ever to raise the required capital to repay the mortgage and resume his Lands. One old Limbu, referring to a Brahmin with whom he had had such an experience, related how the landholder 'would invite me to his home and offer me rice aid neat. Then hu made me put my thumbrints on papers. He would give me a few Rupees and then when I came some months later to return the mortgage and take back my Land, he would say: "this is not enough. Why do you bring me a few rupees and ask for your land back? The document says the mortgage is five hundred and you bring me five! What an I, a fool?" What car you do to such a marl They are all like that, the Brahmins, they are ali treacherous. 'I

When the registration of land transactions became wide-spread after 1945, such abuses were less frequently perpetrated. Sven so, according to one Brahmin informant, clerks in the treasury offices could usualdy be bribed to register amounts wich had not in fact been transferred to the isjpat-owner. ${ }^{2}$ Stild, registration 1. At first I was under the inpression that this was only a local hebit of a few unscrupulous Landholders. But the practice is ilentioned in severcil referunces as being comor throughout Limbuan。 Cf. Bhandari, 1959; Report of the Mulaki Orfice, 1947.

2. In one survey of agricusturat conditions in the eastern hills, the author blowis petty officials for their complicity in afgravating the coriditions of agricultural iraubtedness. '...one can say that the Government officials are the worst exploiters of farmers in the hills.' (Guruing, 1949, 0.9 ) 
has apparentiy alleviated thu problem of mistrust between the cortracting parties. It is worthwhile noting that on the whole ondy lend transactiors livolving Indreni Limbus with menbers of other castes are reglstered. Treasury office records list only four cases where land transactions in. Iripat between Indreni Limbus were recorded. The explanation offered by Limbus ald Brahmins alike is that - Himbus trust one another: they do not have their transactions registered at the office.'

Although the numbers of Brahmins with whon the Limbus have any kind of links represent only a small proportion of the total number in the area, the attitudes and stereotypes are generailzed and applied to the whole group. A legend related by a Limbu ritual specialist expresses the nature of the antagonish. 'A Brahmin and his wife came from the west and arrived at the Mai River. They told the River Goddess that they had nothing and were hungry. She gave then rice, lentils, vegetables and spices. Then she gave them fire, and some vesseis in which to cuok. They ate and rested, and wher it becane derk they went away, taking everything with them. When she saw what they had done the River Goddess thought it would have been better not to sive such people anytining. So she. cursed them and said that she would produce no nore fish. Since that the mon camnot fish in the river and harvests have asso been reduced." 
The hostility felt towards the Brahmins is overtiy expressed in the jegend. The tinenes of theft and deceit which occur here follow the stereotypes held of the Brahmins by the Limbus. The River Goddess, worshipped by all castes, echoes the antagonism and gives it universal chd supernatural sanction. Noreover, production deficiencies in fish and agriculture are referred directly to the stereotypical qualities and behaviour of the Brahmins. The latter, the Limbus would argue, who have abused the kindness and generosity of the River Goddess, have behaved in like fashion towards their erstwhile Limbu benefactors.

The hostility occasioned by land grievances is reinforced by Brahnin attitudes towards Limbus. The term most often applied by the former to the latter is 'simpte' (Lato). Brahmins clain that because Limbus are simple they cire only for the present. A Brahmin irformant observed that if uimbus had thought of the future, the Brahmins would never have been allowed to renain in Ilam since. they would have had no lanus on which to settle. Brahmins express their annoyance wath and fear of their precarious position as Lanholders of kipat, emphasized in continuous wimbu deriends for bard. But, on the other hand: they regard the practice as symptoriatic of the Limbu lack of cuncern for tine future. A Brahmin landholder pointea out that when a menber of his own caste is forcod to pledge raikar lend ho would never aldow his debt to 
increase by adang to the nortgage copital as do the Limbus, since a Brahnin would be concerned first of all with repossessing his land as soon as possivie.

Brahnin attitudes towards Limbus are also conditioned by the special treatment the former traditionaldy received at the hands of the Law. Punishrients and fines were. related not merely to offences but to caste as well. Thus, for example, a member of a Lower caste who was cuckolded by a Brahnin was prohibited from killing the latter: a right which he could exercise under certain conditions against members of any other caste. Brahrinins, too, were exempted from compulsory Labour for Government and from paying certain kinds of taxes, which obligations others, incluaing Iimbus, were required to neet.

The special position of the Branmins was protected in local conditions as weil. In 1957, a quarrel ensued between a Brahmin and a Limbu when the former diverted an irrigation channel into his own paddy field after a kambo Limbu of Chitok had already begun flooding his own terraces situated below. The Limbu struck the Brahmin and the matter was brought to the Panchayat Court. At three separate points in his petition the Brahnin repeated the words: 'I, a Brahmin, was beaten by a Limbu.' When the court, whose inembers were ald Brahnins, fined the kambo, they too concentrated not on the morelity of physical violence, but on the contravention of a ritual code enbodied in the 
caste hierarchy. 'You should not have beaten him because ho is a Brahilin."

Brahmin feelings of superiority are occasioned by diffexences in the religious practices of the two groups. To the extent that we can speak of two systems, it should nevertheless be stressed that the boundaries are not clear cut. For one thing, there is an awareness by menbers of each group of the religious beliefs and custons of the other. Members of one group may profess belief in the efficacy of certain deities associated with the other. Thus, for exampie, rany Brahnins placate the Lirnbu Grandmother godaess aithough the form of worship is adapted to the brahnanic pattern. Limbus, in turn, often rationalize their own religious customs in terms of Hindu beliefs. I Both groups also enjoy a set of convictions regarding certain forms of divination associated mainly with illness, and share a comion pool of ritual specialists for this purpose. Finally, along with the rest of the population Limbus observe the principal Hindu festivals such as Dasein and Tiwar since these have become nationel holy days.

Nevertheless, despite the overlap, we can distinguish analytzcaLiy, as do the Limbus and Brahmins in practice, betweur two aistinct religious systems. The feature most often stressed by members of both groups as symbolizing the distinction is the fact that the 'ruligion of the 1. Cf。 Benedict, 1962, p.1237. 
Brahnins' is a writtan tradition while the indigerous religion of the limbus is not. The following legend, which I hoard repcated on several occasions by Limbus, illustrates the relative value they assign to the two systems.

- Some ancient Hindu sages wrote the scriptures and covered the books with deer skin for their protection, and floated ther in the rivers so that men would find them. Many Brahmins and Limbus found these books. The Brahrins kept thom safe $y$, but the Limbus ate the skin and used the pages for their fires. So the Brabnins leamed how to marry and mourn and conduct their daily lives from these books. But the Himbus who dian't obey these scriptures made their own customs which are not writter down, but are handed on by their forefathers.'

This legend suggests the fact, expressed in other contexts as well, that Limbus have conceded the superiority of the written tradition of Hinduism adhered to by the Brahnins. This is not surprising considering that Nepal is officially a Hindu state and remembering the superordinate status enjoyed by the Brahins. The latter, too, hold in contenpt nany linibu customs which they regard as 'jungasee" ways. They point to the wimbu habit of eating buffalo cira pork and ariukirg spirits and to their pre-conquest traditions of beef-cating, which they corlsider resporsible for the low ritual status of the limbus. 
To sun up, theilo antagoilish between Limbus and Brahmins has energod mainly as a result of e historical confrontation over land. This confrontation has given rise to stereotyped attitudes held by each group about the other. These are both related directly to historical experiences and expressed in terms of cultural differences between the two groups. Moreover, the differences are conceptualized as hierarchic in order. In other words, Brahmins and Limbus are not merely distinct and opposed groups, but opposed in a hierarchy based on ritually assessed attributes.

We might now examilie how the hierarchic nature of Limbu-Brahmin relations is expressed in and reinforced by interaction between nembers of the two groups. There is, first of all, the question of intermarriage. Although the overall caste structure provides for the accomodation of offspring of hyperganous marriages into the (Khatri) Chetri group, both Brahnins ard Iirabus express distaste for such intermarriages. The union of a limbu woman and a Brahmin (or any higher caste) male would place her outside the natrix of her natal group. On econonic grounds alono, her marriage could not be welconed since her group would receive no bridewealth and consequentiy would give no downy. Her kirsmen would take no interest in hor well-beins ard would not offer the protection and support usualdy given a daughter or sister even after 
marriage. Such marriases, in ary case, are a statistical rarity. In one instance I have recorded, the widow of a Kambo man of chitok marriea a Brahmin from a neighbouring settlement. In anothor a Brahmin of Bharapa who spent ten years as a policeman in a town about five miles west of.. the Cluster took a Limbu wife resident in the town. On his return to the Cluster - where he has a Brahmin wife he did not bring the Limbu woman, although he continues to visit her occasionelly and provides for her support. The marriage drew wry comments from Brahmins and Limbus alike, and the husband himself admitted that such unions are regarded with disdain and pointed out that if he had brought her to live in the cluster both he aid the woman would have been scorred by everyone.

Since hypoginous relations until recently were violations not only of caste but of the Law, they cannot be considered es instances of intemarriage. A Brahmin woman (or any other of higher caste) who forms a Liaison with a Limbu, automatically torfents her caste status and assumes that of her partmer. But despite the fact that she is regarded as a limbu in the eyes of the Brahmins dird the Law, she is not considered as such by the Iimbus themselves. The oniy circumstance in which such a relationship could survive would be if both partners fled to a town where they were unknown or, as is usualdy the case for hypoganous couples, if they settied 
in India. In the onily case of this rature involving an Indreni Iinou, which occuiled about forty yoars ago, the couple fled to Assem, severing anl tues with their kinsmen. The man, who was a kanbo, forfeited his share of the household property since he never returned to Chitok. That the burden of the stigma falls most heavily on the woman is illustrated by another exanple involving a Iimbu from a settlemont a few miles from the cluster. After the seduction of a Brabrin widow from the sane settiement, both went to the Darjeeling aroa where they remained for several rnonths. The Limbu then returned alone to Ilan. He was accepted back by his kinsmen and his Limbu wife as a matter of course, but it was clear thet the Brahnin woman could never join him. The imbu's prestige was not at all compromised and as long as he made no attempt to introduce the union into the settlement he suffered no personal disadvantage.

The virtual absence of intemarriage between nenbers of the two groups provides what is perhaps the nost important measure of social 'segregation'. I have already indicated other contacts in which interaction is minimal. Attendance at marriage and mouming rites tends to be restricted to menbers of a single caste group. Wealth aid the patter of residence are partly explantive factors. Numbers in attendarce are limited by the ability of the host to provide the necessary feasts. Theri, the 
obiigation to cousider boids of neighbourhood ensures that guests are draws prinarity from surmovading households which, in nost cases, neais liembers of the host's own caste group. But even where neighbours are nembors of another caste, the additional factor of status differential between host and potential guest contrives to exclude Brahmins from the rites of the great majority of uimbus. But factors of wealth, status and residence are supported by the overridirg opposition of the two groups which, though Largeiy a function of these factors, assumes a reality sui generis. Brahnirs who can afiord a large wedding feast, for exarple, do not invite Lirnbu neighbours to attend unless they are Limbu Notables. Iimbu hosts, in consequence, explain the absence of Brahmins from their rites in terms of their own exclusion from the rites of the Brahmins. The result is a virtual absence of interaction in most of the important social contexts.

In econonic matters, the ties are more widespread, but here too status differentials detemine the nature of the interaction. As shown in Chaptor V Limbus rely on Brahmins for the greater part of their wortgage credit. They are asso dependent to a large extent on Brahmin landholders for tenancy rights by which they earn a substantial proportion of their agxiculturat income. The sume landholdexs hire simbu agriculturat labour to work on fields they do not give to teneits. Brehmins also 
extend a substantial ariount of loan credit to Limbu borrowers. Econonic recessity thus links together members of the two groups. But the prinoipal characteristic of these relationshjps is their contractual basis. Because Iinbus are invariably in the suborainate position the ties are not reciprocal. By contrast, economic links among Limbus, at least until the emergence of a smell wealthy class, tended to be reciprocal and noil-contractual. Limbu households still recruit work gangs on the basis of Labour exchanges. The difference, as I have explained, is related to scarce cash resources anong the Iimbus, to the fact that only wealthy Brabmins traditionally had sufficient lands to require labour they could not repay in kind from their own household, and the reluctance of wealthy Brahmins to send their women to work in the fields of others. Thus labour practices both express and derive from status differentials anong the two groups. The distinctions have begun to blur with the rise of newly wealthy limbus, but even the latter excharge labour with other Limbus, and then hire for wages whatever Labour they still require.

DasLy, in a number of other ways, the hierarchical basis of relations botwoen Jimbus and Brahmins is refiected in interaction. There is, for example, the pattern of deference which symbolizes their respective statuses. The maner in which gruetings are exchanged 
reflects the relative status of the persous meeting. Unless they are kissinein, whut specific forms are called for, it is usual for a subordinate to incline his forohead to be 'tapped" by the super-ordinate. The criteria of relative status are not easy to isolate. Between members of the sane caste they are usually a combination of wealth and age. Across caste Lines, ritual rank becomes an aditional criterion, so that bimbus almost always are the subordinate greeting partners of Brahmins. I llave seen a sixty-year old Subba go along a row .of Brahmins to be 'tapped' and only a small percentage of these were his seniors in age, although most were his economic betters. only those ex-arny pensionors who, because of their age, wealth and overadl status as Notables, are greeted as equals by the most prominent Brahmins. But it is significant that even young Brahmins of inferior wealth do not assune a subordinate greeting posture when meeting these ren: they either avoid greeting them at all, or excharge the equalitarlan namaste salutation. The sane pattem applies to verbal forms of address. Brahing use the lowest honorific grade (ta), which an older genereliy uses to a junior, when adaressing Iimbus, regardess of their relative ages. Here, again, the exceptions are the ex-arny lotables, for whom are reserved the highost howorific grade (tapan) as a sign of rospect. 
Comiensal relations reflect both the ritual and secular statuses of the two castes. Ritually defined norms proscribe the acceptiance by Brahmins of certain foods prepared by limbus. Thus foods Labelled bhat (rice, maize, millet), dal (lentils) or tarkari (vegetables or meat) which are cooked in water by Limbus cannot be eaten by Brahrains. Moreover, such foods, even when prepared by Brahmin cooks must not be eaten unless nembers of the two groups are seated in separate lines. Violation of these rules can lead to a loss of caste. A Brahmin who willingly disregards commensal regulations would cease to be welcome in the kitchens of other Brahmins, would not be able to offer any hospitality to fellow caste members, ard woula not be likely to find a Brahmin spouse for his child.

Considerations of secular status, however, can lead to a widening of comnensal rules such that acceptance of even ritualiy uriruportart foods from Iimbus is not countenarced. Some Brahmins, for example, in attempting to validate high secular stetus, irsist that comriensal prohibitions oxterid to ent types of food. Such attenpts to restrict all comensal interaction ane often the cause of bitteriness aud resentinemt mored iliabus. They argue, as do poor Brehrias, that foods prepared in oil or cicurified butter, or beverages such is tea, are ritually neutral and can be sharud by ali, save untouchables. When I 
asked severa Jimbus in Angbung who make an annul Satya Narayan ritual why tiney prefer a particular Brahmin priest, the reply was that the latter willingly accepted tea and the doughiut-shaped breads (sel roti) prepared - in clarified butter - Ior the occasion. One Limbu changed his Brahmin priest because the latter refused to accept even tea.

Such Brahmins tend to sanction their behaviour by reference to ritual interdictions, but explanation must be sought in terms of secular status. As I have shown in a aifferent context, a man who accepts hospitality adnits the equality or superiority of status of his host. This is true no less of Brahmins than of Iimbus. For example, most of the wealthy ard important men who attended a Brahnin wedding at which I was present left before the wedding feast was served to the guests. One poor Brahmin guest explained sardonjcally that 'big men come arid look, then they Leave; only the poor eat."

In the context of Limbu-Brahmin relations the exterision of comensal restrictions becomes a means of valiating in ritual terms the existence of politicoeconomic distinctions. The ritukil - secular dichotoray js evident when we regard the position of ex-army Notables. Here, comensal relations are proscribed only by focal i.o. ritral limitations。 Brahnins recognize the equality of secular status of these himbus by accepting 
all foods rot prohibited by ritusil considerations.

Iimbu Motables: Iintercalary RoLe

From the foregoing discussion we note that the rise of a small wealthy class among the limbus has begun to alter the traditional relationships between Brahmins and Limbus in the Indreni area. Since the end of the 19th. century, when Brahmins gained control of access to the productive resources of kipat land, their politicoeconomic ascendancy has coincided with superior ritual status. Relations between the groups were thus seen to exist in a single hierarchical order. Woreover, cultural factors tended further to emphasize the structural cleavages. The growth of status differences within the Iirabu commuity, hovever, has led to the emurgence of what might be called an intercalary category in the society. on the one hand, these Limbu liotables have interests in maintaining the unity of the Limbus as a group in opposition to the Brahmins. On the other hard, they have an equal, though contradictory welfare in stressing association with the dominart section within the wader comaunity. In the Pollowirg paragraphs I consider each role in turn. Althuugh Limbu Notablos are treated as a special category by Brahmirs, there is no question of these Limbus validating this new secular status in ritual or marriage terins. Cominensal relations, as I hove stressed, are 
inmutable insofar as cextain foods are never accepted by members of rituaily higher groups. In adation, intermarriage with nembers of higher castes is not an avenue through which socially nobilo imbus in the indreni area can hope to express rusirig status. They terd, therefore, to create marriage links with Limbus of similar status in other settlement clusters, so developing a far reaching network of affines who constitute an elite sector of the Limbu population.

But other kinds of ties to jimbus in the local coimunity cannot be igrored. Ix-servicemen who have achieved prominence require, certainly no less than others, the co-operation of kinsmer, and nelghbours in a number of contexts. The proper rites following on the death of a limbu must be performed by his lineage mates. Crises arising out of marriages, as shown in the previous chapter, require the recruitment of supporters to act on an individuci's behalf. since the marriages and funerary rites of ex-ainy lrotables are grander than those of most less affluent Limbus, the former must enlist more assistance to carry out the mailfold tasks involved in entertairing large numbers of guests at their feasts. They too, require witnesses to sign the many documents they write over land trarisactions, and in the evert of their irvolveraent in disputes, may necd to call on support from within the Local commity. 
Iconomic considerctions a so notivate Limbu Notables to maintain anicable relations within the Local commity. The wealthiest anoing them have takeil a substantial amount of kipat land under mortgage. That portion not given to tenants which they cuitivate themselves requires the hiring of some labour from within the cluster. As I have pointed out, Limbu households which hire out labour accept less than 'market" rates from those to whom they are linked in other social contexts. By accepting the obligations imposed on them by kinsmen and neighbours the imbu Notables thus guarantee their supply of a relatively cheap source of labour. of even greater irportance is the fact that these Limbu landholders can employ their ties of kinship and nezghbourhood to keep open their access to land at a minimum cost. When a servicemen or pensioner enters the market for kipat land he utilizes his relationships within the limbu community to obtain landholding rights to kipat previously held by members of other groups. By difigent attention to his obligations he can expect the kipat-owner to co-operate in trarsferring the landholding rights away from the present laraholder. Once instalded as landholaer humself, the exsoldier seeks to hola the mortgage capital at the lowest possible level and at the sarne tune obviate the possibility that the Lard will be transferred to yet another landholder. In Chapter V I explained how Linbu housuholds can employ their rights of kipat owrership to obtain what amounts to 
interest-free loans which are added to the mortgage capital (bara). These demands are saictioned by the threat of transferring landholding rights. It was susgested that an important brake on the owner's freedon of action relates to the exterit of his involvenent in a multiplicity of other ties with the landholders.

\section{Table 37}

Comparison of mortgage distribution (in units and cash value)

\begin{tabular}{cc}
$\begin{array}{c}\text { Percentage of } \\
\text { Hortgaged } \\
\text { Land Held }\end{array}$ & $\begin{array}{c}\text { Percentage of } \\
\text { Nortgage } \\
\text { Credit Provided }\end{array}$ \\
\hline
\end{tabular}

Iimbus Resident in Cluster Brahmins Resident in Cluster Brahnins Resident outside

$$
\begin{array}{ll}
21.3 \% & 15.5 \% \\
11.3 \% & 12.1 \%
\end{array}
$$

Cluster

$35.6 \%$

$41.3 \%$

Table 37 compares the percentage of the total amount of Land held under mortgage by various categories of landholder with the percentage of mortgage credut provided. It will be noted that Limbus resident in the cluster have provided only $15.5 \%$ of the cash value of ald mortgages on Indreni kipat while holding $21.3 \%$ of the land mortgaged. The proportion is equally favourable for the two ex-army Notables who are tie Largest Limbu Landholders. Between them, they hold $10.1 \%$ of the land and have provided only $6.5 \%$ of all mortgige credit. A relatively greater multiplicity of ties wath jixbus would also provide at least a partial explanation for the fact that Brahinins resident inside the Cluster have provided a lower amount of mortgage credit in 
proportion to the lands they holä uiner mortgage than those resident outside tho Indruid settlemuts.

These figures support the conteition that if a

landholder is a irimbu, he can, by actively cultivating his ties within the Cluster, kep the kipat-owner' demands for bard to a minimun, while successfuldy neutralizing the latter's potential rights of transference of the usufruct. Limbu Notables, in particular, bucause of the strong econonic and political sanctions they can bring to bear to reinforce their kinship and neighbourhood links, are seldorn if ever deprived of landholding rights by transference. I know of only one case where a kipat-owner transferred land away frow a limbu Notable and in this instance there were mitigating circumstances since the former needed the land to trade off to an Indreni Bratumin with whom he was involved in a complicated transaction.

The overall importance of uimbu Notables in the economic life of the Cluster is evident in the numbers of households which are in one way or another dependent upon them. The two wealthiest ex-sorviceners, Lajahang and Parsade, for exemple, are linted as Lingholders to $30 \%$ (22) of all kipat-owidng householas in the cluster. isight of these houscholas are also tonants of ore of these Notables while an additionel two jimbu householàs cultivate as tenarts the kipat of others siven in mortgage to the two men. Soven households, three of thein already linked by 
nortgage or tenalcy ties, are beholden to then for monies borrowed on interest. Their economic relationships extend to all four Indreil settlements and extend beyond the boundaries of linkage or clan segment.

Their wealth confers on them prestige and considerable influence within the cIuster. I have already pointed to the role of Notabies in the mediation of disputes. Their help is also sought in a variety of other natters. On most mornings men from every part of the cluster are to be found in the adjacent courtyards of Lajahang and Parsade. They cone to seek advice on the wording of a docunent, on the advisability of givine a daughter to a suitor, to report the latest gossip or merely to enjoy the company of men from other parts of the cluster whom they otherwise seldom meet. In a very real sense, these ex-servicemen have become the focus of social life in the community.

This suggests that the existence of a nucleus of very weatthy men anodig the Limbus serves an additional, latent, function: the exertion of a centripetal influence on social life in the cluster. This tends to counteract the centrifugal forces of the terrain, settlement distribution and the highity indrviduated character of tho household. Because of their wealth aric status, dimbu irotables bring together at such inportait occasions as weddings ard funerals residents from every part of the Irarcili settlements. At the wedaing of Lajahang's grandsoi, for exaple, (whlch Lajahaing financed 
since the boy was a part of his houschold), every Inareni household was represuited. In tho absence of other clusterwide rituads, these events serve as dimportant mealis of stressing the links anong all residents of the cluster, and bolstering their awareness of themselves as a solidary community.

The importanoe to Iimbu Notables of identiflcation with the Limbu community derives also from their interests in maintainirg the kipat system. Indeed, wealthy limbus benofit most from the system. They obtain access to land at a reasonable cost and on a relatively secure basis. The share of taxes they pay to the kipat owrers is a negligible sum compared to the taxes thej would be assessed or comparable raikar land. Inoreover, the guarantee of perpetual ownership rights enables men to serve in the army for lengthy periods of time in the knowledge that the lands they ara their kinsmen own will still be iutact and, if mortgaged, available for redemption on their returid to active social lite in the community. Thus, ex-army Notables share, in comon with all Himbus, a fundanental interest in kipat and in combatting aruy attempts to compronise their rights. Although none of the indrexi Limbu ivotables was able to be active in the political activities led by the subbas before the overthrow of the Ranis, they did begin to participate in the meetings following their retirenont from service in the early 1950 s. 
Lajaheng, the Cluster's wealthiest Limbu, was on the organizing comittee for a masis weting hela in 1958 to draw up a series of proposals on kipat for the Goverment's consideration.

Wealth and high military ratik earned by Gurkha service also confer on Limbu Notables a high status within the wider comanity. I have noted how Brahnins must adjust their attitudes and behaviour towards a traditzonally urdifferentiated Limbu population to take account of this newly emergent category. The Notables, in turn, seek to validate their new role by adopting some of the cuitural practices usually associated wath the higher caste groups. With greater frequency than their less affluent kinsmen they employ the services of Brahmin priests for a variety of ritual occasions. ${ }^{I}$ Tney assune some brahmanic dietary practices by giving up eating pork or buffalo. Lajahang does not drink beer or spirits. Language, too, has become a symbol of differentiation. Both Lajahaig and Parsade prefer to speak only ivepali to the exclusion of Limbu kura, which both understand without difficulty. The faniliar process of 'sanskritization' thus has led to a blurring of cultural boundarios which iraditionaliy converged with the structural cleavage.

\section{A frequent topic of gossip is how sone Limbu Notables in other areas of inimbuin have begun to marry ote their children by Vedic ritual and to adopt brahranic nourning practices. This has not jot occurred in the Indreni Cluster.}


Notable status within the wider cominuty places these Limbus in a structurat position at which coiflicting role expectations occasionaliy intersoot. As Limbus, they are expected to uphold the norns and velues of the group, which stress opposition to the Brahnins. As Notables, however, they share interests in common with wealthy Brahmins, the protection of which imposes co-operation between affluent sectors of both groups. The intercalative nature of their position was dramatized in the spring of 1964 when rice prices in the area rose in response to seasonal shortages. The District Parchayat offered to import rice from the Terai and sell it to the Parchayat comittee for resale in the Village at Government-controlled prices. In common with other poor sections of the population Indreni Limbus supported the idea. But at the meeting of the Committee where the matter was discussed the 'comprehensive committee' composed of Notables oprosed the schene. The argunent put forward by the opposition was the difficulty of transporting the rice to the Village and the problem of distribution. Informants, however, were quick to note that the Notables, most of whom sold rice in the arein, were conceried about the threat to their owir cointrce. The limbi Notables, who sell very little rice, at first supported the plan since they reanized that the Iimbus would be anong those benefitting fron controlled prices. Under pressure from other ivotabies, however, they agreed to 'further investigation', which efrectively shelved the idea. 
The nature of Iimbu antagoilism to Brahmins conflicts with the desire of uimbu Notables to maintain good relations with Brahnins, especially those in the cluster. The manner in which one minor dispute was settled indicates how highly such relations are velued. When cattle tended by Parsade's son destroyed some wheat growing in (the faction leader) Tunka Nath's fields, the latter tied up the cattle and asked both Parsade and Lajahang to assist in estimating the crop damage. Tunka Nath reminded them that this was the third time such a thing occurred and that if someone other than Parsade's son had been responsible ho would have 'tied him to a post and beat hIm.' The entire procedure of negotiation over the amount of damage was quite unlike any similar occasion I had witnessed. It was characterized by extreme politeness aid constant reassurarces on both sides that there was no quarrel between them, ondy a nced to arrive at a falr figure for compensatioil, so that Parsade's son would readize that he had to be punished for enaangering the good relations which had always existed between these men. Tunka Nath addressed both Limbus in high grade honorific terms and roferred to then as his elder brothers (dajyu). Agreement was reached (over tea) without the need for mediators. Several passersby were asked ondy for their opinion of the anount of dange snce wheat is a new crop in the region. The only note of discord was solinded by one of these observers who inulired if a promissory bond was not required. 
He was turred on by both the Limbus and the Brahmin who reminded hin that the wora of a rotable is sufficient bond. Iimbu Notables are of two minds about their relatrons with the panchayat Comittee. On the one hand, promirent nen are expected to associate thomselves with the aims of the connittee and they are continually pressured by other Notables (and wow by the Govermant) to participate in its deliberations. There are advantages to be gained from such association since the Committee provides the opporturity for a periodic display of Notablilty. on a variety of hoildays the Village's most influential residents are given the platfom for several muntes during which they comment appropriately on the significance of the particutar occasion for the gathering. The order of speech-making reflects the assessment of status, ard the right to speak is usualiy awarded those who attend Committee neetings with some regularity. There is aisother advartago to be gained by attending meetings: the opportunity to influence decisions taken by the Comittee. When one Notable complanned about the anourt he was being asked to contribute towards the erection of the Panchayat building he was reminded that he was invited to attend but had not shown up at the muting at which the assessments were decided. Thus a irotable who rufuses to associate with the Comittee invites criticism from his peers, forfeits the opportunity to display his prominence aud rasks being left out of decisions 
which might sifect hin.

Ow the other haria, if limbu lotables were to be too closely idoutifled with the Comittee, they would be regarded as working hand in hand wath the Brahmins against the interests of the Limbus. Since the Committee is seen by Iimbus as a direct challenge to the traditzonal rights and privileges of the subbas, the ex-servicenen could well jeoparaize their ties withir the jimbu commurity by becoming too involved lis Comittee affairs. Since the Panchayat's inception in 1953, they have assiduously avoided serving as Comittee menbers. When the present system was established in 1962, Turka Nath sought to encourage lajahang to represent the Chitok-Bharapa ward instead of Bishru Prasad who had announced his intention of beconing the caididate. Lajahang refused on two main grounds. Firstly, he was determined to avoid becoming involvod in factional strife ard it was obvious that an overriding notive for Tunka Nath's suggestion was to keep his brother out of the Committee. Secordly, despite the support of the limbu resldents in the ward, Lajahang realized that he would be highly vulnorable to accusations of belng in league with tho Brahmins if he did accept the position. As he explained: oThey (the Limbus) begged ne to be a represeiltative, but if I had, then whenever the Committee would decide arythlise, they would nurmur anorgst thensulves that I was workirg with the Brahmins against then." 
The sane raasonize was behind the inimbu liotables' decision not to serve oil a specicil sub-comittee established to collect assessments for the building project. Both Lajahang and parsade were elected to the sub-comittee's executive at a Comittee meetung which they did not attend. At the following meeting they resigned their posts pleading impendiug absence away from the cluster on other business. The level of assessments was deeply resented by the limbus, a fact of which the rotables were aware. The selsitivity of the latter to any suggestion that they were in any way responsible for categorizing the Limbus for purposes of assessment is illustrated by the following incident. During a meeting with several members of the Commltee a number of Limbus demanded to know the persoil responsible for deciding how the Limbus were to be differentiated for purposes of assessment. Iri an attempt to assuase their resentment, the Comittee nembers stated that iajahang had been present at the meetring in question (which he was) and had taken respunsibility for assigring the inbus to the various categories (which he had not). Tho Limbus thereupon met with Lajahaidg, who assured then that not he but the Brahmin representat 1 ve of the ward had suggested the categorization.

What can be described as the belaice of conflicting expectations on the small class of wealthy ex-servicemen thus defines the lumits of their politıcal actuvities based ors the Committee. Receitiy, however, ilew associations 
have been created under the aegis of the Goveriunent, which provide a franoworis for politicat uxpression by Iimbu Notables. What is noro, by participation in the new associations, they avoid the conflicting denands inherent in their intercalary positıous. This is because these bodies, by their very lature and definition exclude aryone other than ex-servicemen.

The primary school in the Ludreni Cluster was built in 1958 with funds provided by the District soldiers' Board, an organization of ex-Gurkha servicemen with branches throughout those areas of Nepal which contain heavy exarmy populations. The Board was established in 1952 to admisister a furd given by the India Goverment to the Goverrment of Nepal for the berefit of ivepalis who had served in World War II. $\perp$ The monies have beerl used to build dispouseries and schools throughout the country. The District Soldiers' Board provided an initual grant of Rs 750 to build the Indreii school, and contimes to pay the salaries of its three teachers.

The orgarization of the Board in Ilam provides for a three-nen district executive to adninister financial allocations a d to hande matters of liaison with education authorities. The executive appoints a represcntative in each of the dastrict's four sub-divisuors who is responsible for working with tho local school comittees. Lajaheng is

1. The tuid is called the Ceistral Comorditation Board postwar Recoistructioi Fund. Cf. Hitchcock, 1963, p.80. 
vice-presidert of the District soluiers" Bourd in Ilam and Parsade, his younger brother, is the Board's representative for the Ilam-Darda sub-division.

The former has been president and the latter treasurer of the indrerii school committee sirce its creation in 1958. Beceuse the curriculun of the school is laid down by the iational education authorities, the comittee has a largely administrative and watchdog function. Meetings discuss payment of school fees, employment of teachers and maintenance of the buildirg.

In contradistinction to their attitude to the Panchayat Conmittee, Indreni Limbus regard the school committee as represeiting their ow interests. Because it is effectively controlled by Limbu Notables, other Limbus attend its meetings ald accept minor responsibilities if asked to do so by the executive. Of the twenty members excluding the presideut and treasurer, nune are Iimbus from the Indreni Cluster, though ouly four of these have children attending school. The remaluder are maindy Newars and members of other non-high caste groups.

The ex-Servicenen's Assoczation provides Limbu Notables wath yet another framework for political activity. The Association is one of seven "class" organizations created along with the Palchayat systen in 1962, and is designed to serve the interests of veterans of the Ludian, British 
and Nepai amies. ${ }^{I}$ The orgailation of the Association parallels the four-tier paichayct structure with executive bodies at the viliage, district, zoral and nationel levels, and sends two representatives to the National Panchayat. Lajahang and Parsade are chaiman and treasurer respectively of the Village executive, and Jainare, the only other Limbu who can be termed a Notable, is its secretary. 2 Parsade is also treasurer of the district executive, while Lajahang is a member of the zonal executive. The Association concerus itself wath improving pension-paying facilities and money transfer arranements for servicemen, so that its activities are conducted outside the arena of settlemont politics. Recently, however, the distract executive obtained a grart of land in the Qerai adequate for the resettlement of 200 fanilies of ex-servicenen in the first stage. Conceivably, nembership on the Village executive, hitherto a post couferring prestige but little other advartage, could become important for dispensing patronage. But this is stili lis the future.

1. The other six 'classes' similarly orgarized are peasants, labour, women, students, youth aila chileren. By 1964 onIy the ex-Servicenen's Association had established an orgarization in the settleneits of Ilas.

2. To estabiish a 'Viliage' executive there must be 100 exservictiser who are paid up mubers of the Association. For this reason areas under the jurisdiction of more than oile Pallichayat Comittec may be amalgameted as a Village for the purposes of the Assoclation. There are thirtyeight such urits in riem. 
CHAPTER IX

CONCLUSLON

One way of approaching the study of social change is to focus on the causal interdependence and co-variation among certein events. I This necessarily involves a process of selection. Even if we make no attempt to attribute change to single causes, we nevertheless ignore many conditions precisely bocause the phenomene are so complex, and we cite only the most important causes. ${ }^{2}$ In this thesis, I have identified the kipat system of land tenure and the effects of Goverumont policy on that system as the principal catalysts of social change in the Indreni cluster of settlements.

Inplicit in the analysis was the distinction of two historical periods within each of which certain economic and political institutions were seen to be interrelated in a systematic way. No single dratiatic event allows us to pinpuint a specific moment in time before which a certain social pattern obtained and after which it vas replaced by a different pattern. But the facts suggest that towards the end of the ninetoenth century the introduction by Goverment of certain policies rolatod to kipat land set in motion a number of processes which, both singly and in combination with other devolopments such as those related

1.J.B. Watson, 1953.

2. Ginsberg, 1958 . 
to military service and the comurcial growth of Ilam Bazaar, brought about the social changes which $I$ have described. For the purposos of this sumary I refer to the time befure the effects of these processes became evident as the Early period.

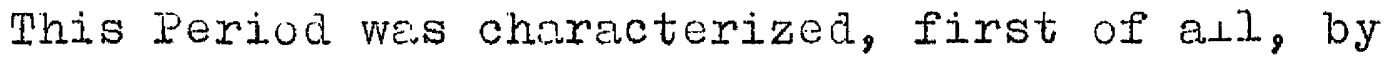
a subsistence econony, in the sense that agricultural requirements were met within the cluster. Some of the prociuce was undoubtedly traded in the region to acquire the few guods which could not be made or grown locally, and to find the cash needed to pay texes, but by and large the economy was self-sustaining. Mair has argued that in such an economy there could be no commodity more valuable than land, $n o$ circumstance in which it would be profiteble to dispose of land. 1 I think this is true of the Early period in Ilam, but I would stress also that an cibundarce of Land was as much a reason for this fact as the existence of a subsistence economy per se. Iand had no exchange value because it was a freo good. This meant that production was Iimited primarily by technological know-how end the supply of labour. Availability of land explains the readiness of the limbus to make generous grents of Holdings to the non-Iimbu imrigrants who entered the district in tho wake of the Gorkha army. Regmi has suggestud that the londs may have been given for finereial gain, ${ }^{2}$ but it sems possible to speculate 1. Nair, $1957, \mathrm{p} .46$.

2. Mi.C. Regmi, $1965, \mathrm{p} .97$. 
that tho immigrants were unlikely to have had sufficient resources to invest in land; certainly, the story as the Iimbus tell it is very different. In any case, what is clear is that land was given in return for economic and political support, so that in Gluckman's terms the 'series of estates in land ${ }^{1}$ mirrored the political hierarchy of subbas, Tharis and dependents. The hierarchy was bolstered by the various prerogatives enjoyed by persons in superordinate positions vis a vis their subordinates and symbolised in the system of tributary payments. The subbas, then, stood at the sumnit of a political structure based on differential rights to Iand.

Their political roles had another dimension as well. As Lineage headren they were the dominart leaders within the Iimbu comunity. Here, too, control of land provided the basis of their power. The right to allocate kipat constituted a principal senction of hoadnanship and emphasized the corporateness of the lineage. Households obtained secure rights to an estate by virtue of membership in a patrilineage which implied, anong other things, allegiance to a Subba. It was shown huw, in conditions of land plenty, tho lirege dpearod not overly concerised with defining menbershnp crituria tou aarrowly. As a result, outsiders were occasionily absurbed into the lineage or 'accomodated in uther way. The descre to exhance a political 1. Gluckman, 1943, p.45. 
following would sem to have motivated this proctice. But ever in the Early period the political organization could not be expressed in toms of the relations betwoen limou descent groups. Whatever the system existing in Ilan in pre-Gorkha tines, the imposition of rule by the liethmandu Goveriment left no doubt where the monopoly of power resided. Yet, by incorporating the existing hierarchical structure into the administrative apparatus of the state, the Goverment, for a tine at least, crystallized the authority of the subbe and the strength of the lineage he headed. In their roles as tax-collectors and the main instrumonts of adrinistrative control in the settlements the Subbas powers were sanctioned by the authority of the state.

The politico-economic conditions existing today follow from several intercomected developments. One kind of development relates to land shortages caused by the pressures of population growth and exacerbated by a Government decree converting into raikar tenure all land grants made by limbus to imigramt settiers. In the cuurse of the alicilysis soveral effucts" have been noted.

Pirstly, the criterie for lineage membership have becone more stringently defined in order to limit the numbers with rishts to kipat. As a rosult, the ciluster is now inhebited by a number of Limbus without cwnership rights to kipat land within the Iadreni settlemunts. 
Secondin, in the absence of surplus Lands to allocate, the Subbas have lost the economic sanction for their power and influence in the lineage. In rare instances where lands are abandoned or become vacant through the absence of ineal heirs, households related as co-heirs are quick to press their rights to the vacated land. Iineages have lost their corporate functions in respect of land, as households have acquired and exercise greater rights against the former. Moreover, with the introduction of a rule requiring the registration of land titles on an individual basis, the household no longer need reassert continuously its membership in a wider kin group. The fact that the household is the most important corporate group in the Iimbu community presented certain problems of method and anaiysis. Traditionally, anthropologists have equited the study of small-scale societies with the study of relations between structural groups of varying depth. In many areas undergoing change this orientation is no longer useful. Even Bott's guarded statement that 'in a small-scale, relatively ciosed society, the encapsulating (viz. local or kin) groups have a great deal of control over the family" is clearly not appropriate to the Iimbu context. I To use Bott's own term (in a qualified way) the Limbu household is a comparatively 'individuated' unit. ${ }^{2}$ The household

1. Bott, 1955, p.374.

2. By 'individuation', says Bott, "I nean that the elementary fanily is separated off, differentiated out as a distinct, and to some extent autonomous socied group..." Ibid, p.375. 
exercises a wide measure of choice in the formation of social ties. Through its control of an estate, which is further secured by the rule prohibiting the permanent aliension (i.e. sale) of land held under kipat tenure, the household is able to manipulate its rights to gain the maximum advantage for itself.

I have not tried to suggest that a household is completely unhampered in its freedom to enter into or opt out of social ties. There are restraints, of course, but these are not, by and large, the restraints of encapsulating groups. The limitations on a household's freedom of choice are referable, rather, to the restrictions of poverty, which necessitate the establishment of credit and tenaricy Iinks with wealthy elements in the population; to the requirements of agriculture, which compel the household to rely for assistance in cultivation tasks on its neighbours: to those situations which induce it to call on others for support or to mediate in its disputes; and so on. Thus, from the point of view of any household it is the muitiplex pattern of ties in which it is ensconced which dictates the boundaries of choice.

Precisely because of the smaliness of scale of rural communities many of those on whom a household relies for assistance may share mombership with the focal household and with each other in ongoing groups. But the reasons for which they are recruited may have nothing whatever to do with this fact. It is not necessarily beckuse they are 
lineage or clan mates that a household secks their help; it may be because they possess certain qualities or attributes which the focsil household requires at a particular time to press its own advantage. In other words, the alignment of households in groups may be distinguished from and irrelevant to their alignment in ego-centred 'networks' or 'action-sets'. In such circumstances it was thought best to concentrate in the andysis not on the relationships between kinship groups, but on the nature of the ties emanating out from individual households and the ways in which they are utilized in social situations.

A third outcome of the land shortages which occurred around the turn of the century relates to their effects on household composition. iven as household estates have become smaller and less viable, the tendency has been for young men to press for partition and a division of property shortly after marriage. The trend has become even more pronounced with the growth of new commercial opportunities outside the agriculturat economy. As young men begin to recognize their importance as earners of wealth in the cash economy, they are more reluctant than ever to share these earnings with a large farily group. $\perp$ This is especially evident in the case of some army servicemen who, even before marriage, act as heads of potential households

1. This kind of trend has been noted in areas where labour migration is an important part of economic life. See Firtin, 1954. 
by retaining a substantial proportion of thejr earnings against the time they will marry and establish an independent unit. The efforts of their elders to keep the household estate intact for as long a period as possible are rendered ineffective, and oniy the wealthiest households can hope, by holding out the prospects of an expanding estate, to delay the process of division. Thus, as the rate of land fragmentation has increased, household size has become smaller and these groups progressively less able to support themselves from the land.

Fourthily, in the absence of alternative sources of income during the latter part of the nineteenth and early part of this century, a dearth of land meant that household obligations could oniy be met by mortgaging kipat land to non-limbus. There emerged the familiar syndrome of agricultural indebtedness: as more and more lands were pledged to raise non-productive capital, the Iimbus gradually lost the means to repay these debts and resume their lands. Thus, the economic foundation on which the political hierarchy of the teriy Period had been built eroded with the generat impoverishment of the Limbus - Subbas and their lineage mates alike. The twice-born castes, especially the Brahmins, becane the economically ascendant sector of the population, and the chief source of credit and tenancy for the Limbus. Woreover, tho conversion of their land grants into raikar tenure in the 1800 s secured the 
$x$ ights of the non-Limbus to these lands and freed them of any further econoric or political dependence on the limbus. Thereafter, the Tharis were beholden to the Government and not the subbas for their tities and authority. When the system of tax-collection was re-arranged so that Tharis paid taxes directly to the treasury office instead of to the Subbas, the last remnants of the hierarchy were dissolved in Ilam.

Another development which had a profound effect on the social pattern relates to the Government decision of 1901 to prohibit the permanent alienation of kipat land to non-Limbus. Since pressures on raikar land have been growing steadily, non--imbus have been forced to compete for access to the usufruct of kipat lands. This has placed Limbus in a position from which to exploit their ownership rights by demanding interest-free Loans (bard) against the security of lands already pledged. In addition, they retain the right of first refusal of tenalcies in the event that the mortgagees can or will not cultivate the Lands themselves. These rights, moreover, are sanctioned by the threat of transferring the usufruct to new landholders. The effects of impoverishment are thereby mitigated so that the pattern of totel econonic dependence which characterizes the rolations between, for example, landioräs and non-Limbu landless has never developed. And the fact that now Lirnbu 
households can get at loast a part of thoir living from commerciat sources has reduced further their dependence on the non-iimbu landholaing class.

The retention of ownership rights to kipat is especialiy important in the context of military service. Because Land rights remain intact during their lengthy absences, servicenen are able to accumulate substantial. savings and pensions which are used to regain usufruct to their own lands or to take the lands of other Iimbus under mortgage. This means that the proportion of lands to which the Jimbus now have "unrestricted" access has begun to increase at the expense of the Brahmins and other non-Limbus. It means, too, that monies earned in the commercial economy contribute to slowing down the rate of kipat mortgaging. Moreover, as these monies find their way back to the Indreni Cluster, the agricultural sector of the limbu economy improves accordingly.

The political effects of these new alternatives have been no Iess far-reaching. Service in the Gurkhas has given rise to a small class of affluent Limbus, who through their weaith and status earned in the army, have usurped much of the power and influence of the traditional Iimbu headmen. Of equal inportance is their assunption of leadership within the wider community - the all-Nepal arena, so to speak - expreassed in their control of new political associations created by the Governinent. 
Colson points out that the existonce of the Makah 'as a distinct group" is due nainly to 'the creation of a separate stutus for the Wakeh by the reservation system. I The livepal Government's ban on the sale of kipat can be seen in a similar Light. By halting the trend towards abolition of this form of land tenure, the Government inadvertently provided a new impetus for the timbu struggle to defend their Lends against encroachment.

The kipat system biends with and adds a structural dimension to the fact of custural exclusiveness. Limbu relations with and attitudes towards their Brahmin neighbours are influenced by the fact that the latter have benefitted most from the Government's land policy: indeed, they are seen as the instruments of that policy. In a different direction, the continuing infiuence and prestige of the Subbas are explicable, too, in terms of the confrontation over land. Their traditional importance as lineage headmen has given way to their roles as symbols of limbu unity. Not onily have they been in the forefront of the political activity over kipat, but express the opposition of the Iimbus to the Panchayat systen, which is seen both to be controlled by the Brahmins, and to represent the greatest obstacle to a resurgence of the traditional powers of the headinen.

1. Colson, 1953, pp.144-5. 
In 1964, a comprehensive series of land reform measures were announced by the kathmondu Goverminent, and the intention is to introduce the programine in all areas of the kingdom not later than 1967. Although nowhere in the legislation is specific reference made to the future of the kipat system, the successfui implementation of such a scheme would seen to be predicated on the prior conversion of all lands to raikar tenure. Whether or not this will be done remains to be seen. In the light of this study, however, it is safe to assume that the abolition or fundariental alteration of the kipat system of land tenure would bring about further changes in the existing pattern of social relations. 
APPENDIX

The yeasuremut of Irand

The problen of measuring land arose early in my fieldwork and proved something of a problem. The last revenue settlement in Ilam took place in 1936 so that the records were out of date and of little value. Moreover, only irrigated lands were in fact surveyed, but dry fields were not.

Hill peasants themselves have no exact knowledge of the size of the fields they cultivato. They speak only of the amount of seed they sew in the case of paddy lands, and of the number of hul they own when referring to dry plots. A hul nears a pair of bullocks, and in this context inplies the number of mornings it takes to plough a dry field. This gives no indication of its size since the figure varies with the condition of the soil, the time of year, the strength of the bullocks and the skill of the ploughnan.

Under these circumstances the only alternative was to use the figures for production. A 'unit' therefore, is not, strictly speakine, a measurement of land, but of its productivity. The figures given in the text are for the year I spent in the field. There is nothing to suggest thet 1964-65 was a year of abnormal yield - either below or above par. 
There are two weaknesses in this approach which become immediately apparent. The first is this: how was I to know whether the production estinates given me by my informants were accurate? Jimbus, like peasants everywhere, are never happy to speak about their yields. But the fact that the great majority of their fields were mortgaged made them Iess reluctant to give me the information I asked for, and at the sane time made it possible for me to check their statements. Since in most cases two and often three persons had rights to the same plot of land I was able to verify the production figures by relying on more than one source. Then again, certain areas were known to yield a determinate quantity of grains per seed planted. So that, for example, most cultivators knew that fields along a specific ridge produced twenty times the amount of seed sewn, while others in another area produced twenty-five or thirty times the anount. This provided an additional means of verification. Finally, I was present on a number of occasions when grains were counted at harvest time, and was able to check perscnally the statemunts I had taken.

Perhaps a more serious arawbak of attempting to employ proauction figurus as an objective measurement of land relates to the fact that yields can vary from year to year. In this regard I car only point out that any significant variations in production would occur 'across tho board and so would not substantially altur the land pattern I present. 
Because agricultural techniques are standardized the skills of individual cultivators would have little bearing on yields. The figures given in this thesis are therefore presented as a reasonabiy accurate estirate of the production of Indreni kipat fields.

To enable me to compare production with consumption requirements I have defined the 'unit as the anount of food an adult (aged fourteen and over) eats in one day (two meals). With the husks removed two measures of paday will give one measure of rice. A measure of maize on the cob will give three-quarters of a measure of edible grain. Millet, on the other hand, is reckoned to give full 'measure for measure'. The figures used, then, are for net edible grains.

Crops are normally measured in muri, pathi, and mana. One mana is equivaient to about one pound. There are eight mana in a pathi and twexty pathi in a muri. One muri corresponds to a volumetric measure of 2.4 bushels. An adult eats one mana of neal (whether rice, maize or millet) at a single real. 


\section{GLOSSARY}

aq̣वृa

am峝

aputāi

asik

baq

baq̄ā hākim

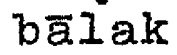

$b \bar{a} I \bar{I}$

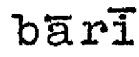

be $\int y \bar{a}$

bəysākh

bhaladmi

bhāt

bhog bandhaki

bi rodhi

boknu

boksi

budeuli

buac

candā

chumlung [I]

cori biha

culo

daijo

dājyนี-bhāi

de्al

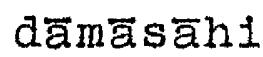

qera

dhän n⿳亠口八c

dhāra

dhoti

dukha office

Subba's court or council.

childiess person

blessing

1it. increment. An additional loan taken against security of land already pleaged.

Governor of a district infant

annual payment in grain made to a member of a service caste

dry (unirrigated) land

whore

first month of Nepali year

notable, important person

cooked rice, maize or millet

possessory mortgage

opponent

to carry, to support (in a dispute)

witch

spokesman

an elder

contribution

mass meeting

theft marriage

hearth

dowry

brothers

lentils

a proportion of tax paid by landholder to the owner of kipat land. a temporary shelter

Limbu paddy dance

water source

loincloth

hardship 
gฐ̃

ghar

ghar bāri

gothālo

gotra

guhã

hal

$j \tilde{a} q$

j到

jāri

jārikal

$j \bar{a} t$

jetha

jiuni

jutho

$\operatorname{kam}[\mathrm{L}]$

kanya

kartā

k范 $r b \bar{a} \mathbf{r}$

khar

khet

khukuri

kipat

kiriya putra

kul deuta

kurā

Iagan

İ̄Imohar

Iato

lokanti

mägh

mägi biha

māl

mana

marcä settlement, village, cluster of houses home, household

homestead plot

cowherd

an exogamous unit usually wider than clan

help

amount of land plougned by a pair of bullocks in one morning

millet beer

treachery

marriage by anduction of another man's wife

compensation paid to a cuckolded husband caste

eldest sibling

property kept by parents for support in

old age

ritually impure

soil

virgin, unmarried girl

functionary appointed by Subba

functionary appointed by subba

kind of grass used for thatching

irrigated land

curved knife

form of land tenure associated with Limbus principal mourner

ancestor god

language

wedding ceremony

decree bearing the royal seal

simple, stupid

women accompanying bride to her wedding

Nepali month

arranged marriage

treasury office

unit of measure (about one pound)

yeast loaf used in making liquor 
mãsikātta

matvāli

mลำ. I

mit

mtil ghar

muri

namaste

nāu kamaunu

navami

nimto

nqn tel chunu

nvāgi

p ̃̄a khat

pakka

pāni na calne

papp

pareli

päthi

pāths $\bar{a} I \bar{a}$

perengo [I]

peva

phedangma [L]

polah $\bar{a}$

purohit

rāi

raks 1

ratyowIi

reybandi

rəykar

reyti

rin

rit kind of possessory mortgage whereby capital is reduced annually by a fixed amount.

member of a 'arinking' caste, ranked below twice-born castes

mother's natal family

ritual friend

main house (from which sons divide)

unit of measure ( 2.4 bushels, also

$1369 \mathrm{sq} . \mathrm{ft.})$

popular form of greeting

to make a name, earn a reputation

ninth day of the festival of Dasein

invitation

touching salt and oil (a ritual

lifting pollution after a death)

ritual offering at harvest time

certain offences which can be dealt

with only by Government courts

real, genuine

untouchable (caste)

$\sin$

mutual labour exchange

unit of measure (equal to eight manas) religious school

small wicker purse containing meat (given as part of marriage payments)

a woman's private possessions

Iimbu ritual specialist

Informer

Brahmin priest

functionary appointed by subba

liquor

performance by women $0 \mathrm{i}$ a groom's

settlement on the night of his wedding

(practised by high castes only). system of periodic re-distribution of land

form of land tenure (akin to freehold) dependent of a headman

interest-bearing loan

marriage payments made by groom 
sabhä

saimondri [L]

sanad

sapat

sarāp bag可unu

sel roti

sĩdur

sikya [L]

silok

sir uthäune

soranni

subbā

suhang [L]

sunauli $[\mathrm{L}]$

tã

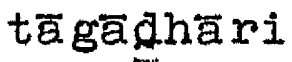

tapti

tarker $r \bar{i}$

thar

thari

thum

tikn

tongba [I]

tulasi assembly of Village adults

fee paid by man to wife's natal

kin to enable former to mourn wife Government oxder

short-term loan without interest ritual performed to 'wash away' ill

feelings within a lineage

kind of doughnut made on special occasions

red powder worn by bride to signify marital status

nettle

verse competition engaged in by relatives of bride and groom at a high caste wedding

raise one's head i.e. prestige

land grants given by subbas to immigrant settlers in Iimbuan

Limbu headman

sub-division of the tribe

brideweal th

Low grade honorific form of 'you'

twice-born caste

high grade honorific form of 'you'

vegetable or meat curry

clan

headman on raikar land

sub-division of a district

ritual mark on forehead

bamboo container with millet beer

a sacred plant (ocimum basilicum) 


\section{BIBLIOGRAPHY}

Bailey, F.G.

1957. Caste and the Economic Frontier. Manchester, University Press.

1960. Tribe, Caste, and Nation. Nanchester, University Press.

1961. "Tribe" and "Caste" in India", Contributions to Indian Sociology, 5, pp.7-19.

1965. 'Decisions by Consensus in Councils and Comnittees' in Political Systems and the Distribution of Power.

(ASA Monograph 2) eaited by II. Banton. London:

Tavistock Publications.

Benedict, $B$.

1957. 'Factionalism in Mauritian Villages', British Journal of sociology, 8, pp.328-342.

1962, 'Stratification in Plural Societies', American Anthropologist, 64, pp.1235-1245.

Bhandari, K.P. 1959 (in Nepali).

'Kipat', in Samyukta Prayas, Kathmandu, 13th and 20th September.

Bott, E. 1955.

- Urban Fanilies: Conjugal Roles and social Networks', Human Relations, 8, pp.345-384.

Buchanan, F. 1928 (see Hamilton, 1928).

Campbel1, A. 1840.

Note on the Limboos, and other Hill Tribes hitherto undescribed', Joumal of the Asjatic Society of Bengal, 9, pp.595-615.

Chatterji, S.K. 1950.

'Kirata-Jana-Krti", Juurnal of the Royal Asiatic Society of Bengal, $16, \mathrm{pp} .143-235$. 
Chemjong, B.B. 1957 (in Nepaii)

Palio-kirat Limbuan Ka lyeg Horu (Denands of Iimbuan Far-Kirat,) kathmandu.

Chemjong, I.i. (in NepaIi)

1952. Kirati Itihas (History of the Kiratis). Gangtok.

1961. Introduction to Iimbu-Nepali-Angrezi Shabda Kosh (Iimbu-Nepali-EngLish Diotionary). Kathmandu: Nepal Academy .

Cohen, A. 1965.

Arab Border-Villages in Israel. Manchester, Univorsity Press.

Cohn, B. 1955.

'The Changing Status of a Deprossed Caste" in Village India, edited by M. Marriott, Chicago, University Press. Colson, E.

1953. The Makah Indians. Manchester, University Press. Davis, I. 1951.

The Population of India and Pakistan. Princeton, University Press.

Donaldson, F. 1900.

Iepchaland. London: Sampson Low, fifarston.

Driver, J.U.S.S. 1963.

'Party and Govermment in Nepan' in Politics in

Southern Asia, edited by S. Rose, London: Jiacinilian.

Eisenstadt, S.N.1961.

-Anthropological Studies of Complex Societies", Current Anthropology, June, pp.201-222. 
Firth, R.

1954. 'Mifoney, Work and Social Change in Indo-Pacific itconomic Systems', Internationel social facience Bulletin, $6, \mathrm{pp} \cdot 400-410$.

1957. Introduction to "Factiors jin Indian and overseas Indian Societies', british Journat of Sociology, 8, pp.291-295.

Freedman, H. 1958.

Iineage Orgenization in Southeestern China. Iondon: Athlone Press.

Fried, M.H. 1957.

The Classification of Corporate Unidineal Descent Groups', Journal of the Royal Arthropotogical Institute, 87, pp.1-29.

Furer-Haimendorf, C. von. 1956.

- Elements of Newar Social Structure", Journal of the Royal Anthropological Institute, $82, \mathrm{pp.15-38.}$

Ginsberg, M. 1958.

'Social Change', British Journal of Sociology, 9, pp. 205-229.

Giuseppe, Father 1790 .

'An Account of the Kingdom of Nepal', Asiatick Researches 2, pp. 307-322.

Giuckman, M. 1943.

Lozi Land and Roycl Property. Thodes-Livingstone Papers, No. 10 London: O.U.P.

Gough, K. 1955.

'The Social Structure of a Tanjore Village' in Viliage India, edited by M. Marriott, Chicago, University Press.

Gould, H. 1964 .

'A Jajmani System of North India: Its structure, magnitude and neaning", ithnology, 3, pp.12-41.

Gurung, C.B. 1949.

Report on the study of Arriculturat Conditions of the Eastern IVepl Hilds, East No. I to Ilan. (mimeographed). 
Hailey, Lord 1952.

The Land Tenure Probler in Africa", Journat of African Adrinistration (special supplencnt), pp.3-7.

Hamilton, F.

1819 An account of the kingdom of Nepal, and of the territories armexed to this dominion by the House of Gorkha. Edinburgh: Constable. 1928. An Account of the District of Purnea in 1809-10. Patna: Bihar and Orissa Research Society.

Harper, E.B. 1959.

'Two Systems of iconomic Exchange in India', American Anthropolosist, 61, pp.760-778.

Hitchcack, J.I.

1963. 'Some Lffects of Recent Change in Rural Nepal', Human Organization, 22, pp.75-82.

1966. The Hagars of Banyan Hill. New York: HoLt, Rinehara and Winston.

Hodgson, B.H.

1880. 'Route from Kathmandu, the Capital of Nepal, to Darjeeling in Sikkin', section XI in Miscellaneous Essays Relating to Indian Subjects. Vol. II, London: Trubner.

n.d. Hodgson Collection. Miscellaneous texts presented to the India Office Library. Unpubtished.

Jackson, R.D. 1940 .

India's Army, London: Sampson Low, Harston.

Karve, I. 1965.

Kinship Organization in India (second revised edition). Bombay: Asia Pubiishing Fouse.

Kolenda, P.II. 1963.

"Toward a Hodel of the Hindu Jajmani System" Human Organization, 22 pp.1I-3I.

Kumar, D. 1965.

Land and Caste in South India. Cambridge, University Press. 
Kuper H. 1947.

An African Aristocracy: Rank emong the Swazi of Swaziland. London: International African Institute.

Lama, S.B. 1959 (in Nepali)。

Ilam Darpard (Mirror on Ilan). Dar jeeling.

Landon, P. 1928.

Nepal, 2 vols. London: Constable.

Leach, E.R.

1961a. Rethinking Anthropology. London: Athlone Press 1961b. Pul Eliya. Cambridge, University Press.

Liloyd, P. 1962 .

Yoruba Land Law. London: O.U.P.

Mair, L.P. 1957.

Studies in Applied Anthropology. London: Athlone Press

Malhotra, R.C. 1958.

'Public Adninistration in Nepal', Indian Journal of Public Administration, 4, pp.451-464.

Maron, S; Rose, İ and Heyman, J. 1956.

A Survey of Nepal Society. Berkeloy: University of California.

Marriott, Ni. 1955.

'Iittle Communities in an Indigenous Civilization" in

Village India, edited by M. Narriott. Chicago,

University Press.

Mayer, A.C.

1952. Iand ard Society in Malabar. London: 0.U.P.

1957. 'Factions in Fiji Indian Rural Settlements', British Journal of Sociology, 8, pp.317-328.

1960. Caste and kinship in Central India. Berkeley: Univerisity of California.

1963. 'Some Politicat Inplications of Community Development in India", European Journal of Sociology, 4, pp. 86-106. 
Nilayer, A.C.

1966. The Significance of uasi...Groups in the Study of Complex societies" in The Social Anthropology of

Corplex Societies (ASA lionograph 4), ddited by ifl. Banton, Iondon: Tavistock Publications.

Nakane, C. 1966.

"A Plural Society in Sikkim" in Caste and Kin in Nepal,

India and ceyton, edited by $c$. von Furer-Haimendort,

Bombay: Asia Publishing Fouse.

Nebesky-Wojkowitz, R. von 1956.

Where the Gods are Nountains. London: Weidenfeld and Nicholson.

Nicholas, R.W. 1965.

"Factions: A Comparative Analysis", in Political

Systems ard the Distribution of Power (ASA lionograph 2), edited by M. Banton, London: Tavistock Lublications.

OPMlley, U.S.j. 1907.

Bengal District Gazetteers: Darjeeling, Calcutta:

The Bengal Secretariat Book Depot.

OpLer, Hi.lí 1956.

The Extensions of an Indian Village", Journal of Asian Studies, 16, pp.5-10.

Orans, H. 1965.

The Santal. Detroit: Wayne State University.

Pant, Y.P. 1965.

Economic Development of Nepal. Allahabad: Kitab. Mahal.

Patterson, G.IN. 1962 .

'Recent Chinese Policies in Tibet and towards the

Himalayan Border States', The China wuarteriy,

12, pp.191-206.

Phago, J.S. 1843 .

see Hodgson, (n.a.). 
Pradhananga, G.B. 1952 (in Nepaii).

Iimbuan Ko kipat Sumasye (The kipet Iroblem of uimbuan). Kathinandu.

Rao, M.S.A. 1957.

Social Chanse in Matabar. Bombay: Popular Press.

Regmi, D.R.

1960. Ancient Nepal. Calcutta: k.I. Mukhopadhyay . 1961. Modern Nepal. Calcutta: K.I. Mukhopadhyay.

Regmi Mi.C.

1963. Land Tenure and Taxation in Nepal. (Vol. I) The State as Land lora: Raikar Tenure. Berkeley: Institute of International studies, University of California.

1964. Iand Tenure and Taxation in Nepal. (Vol. II) The Land Grant Systen: Birta renure. Berkeley: Institute of International studies, Juiversity of California.

1965. Iand Tenure and Taxation in Nepal. (VoI. III) The Jagir, Rakan and Kipat Tenure Systerns. Berkeley: Institute of International Studies, University of California.

Rock J.F. 1953.

'Excerpts from a History of Sikkim", Anthropos, 48, p. 925-948.

Rose L.R.

1963a. 'Nepal's Experiment with Traditional Democracy', Pacific Affairs, 36, pp.16-31.

1963b. "The Himlayan Border States: "Butfers" in Transition', Asian Survey, 3, pp.116-121.

Tuker, Sir. F. 1957.

Gorkha, the story of the Gurkhas of Nepal. London: Constable.

Vansittart, 世. 1915.

Gurkhos. Calcutta: Superintendent of Government Printing. 
Watson, J.B. 1953.

- Four Approaches to Cultural Chenge: a systematic Reassessment", Social liorees, 32, pp.137-45.

Watsons W. 1958.

Tribal Cohesion in a Honey Economy. Manchester, University Press.

White, C.M.N. 1958.

'Terminological Confusion in African Land Tenure', Journal of African Administration, 10, pp.124-130.

White, J.C. 1909.

Sikhim and Bhutan: Twenty-one Years on the North-West Frontier. London: Hdward Arnold.

Worsley, P. 1961.

See Eisenstadt, S.N.

Wright, D. 1958.

History of Nepal. Calcutta: Susil Gupta. (Indian reprint. First published by Cambridge in 1877).

Primary Sources

Royal Order to the Limbus of Far kirat, 1774.

Order regarding the failure to register lends and homesteads in Far Kirat, 1868.

order to the Dhankutta district court, 1880.

Order regarding the restoration of kipat lands in Far Kirat, 1881 .

Order to the officers and clerks of the Ilam adinistration, 1913.

Order regarding kipat Land in Ilam and Das inajhia, 1917.

Report of the Iluiluki office, 1947.

Petition of the subbas of Ilam, 1951.

Report of Deva Man Angaembe to the Shahi Commission, 1960. 